\title{
EXPERIÊNCIAS EM EDUCAÇÃO ARTÍSTICA E DECOLONIALIDADE
}

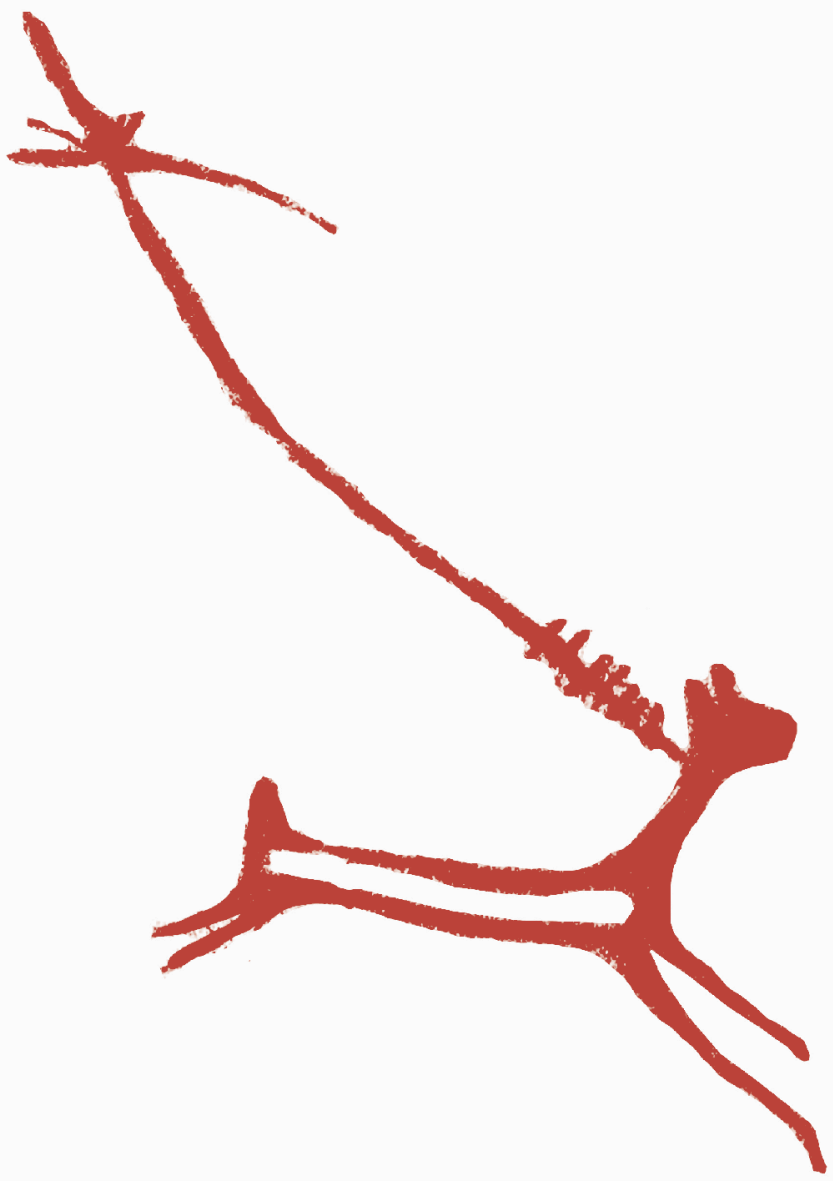

Ed.

EDITE COLARES

JOSÉ CARLOS DE PAIVA 
<smiles>C=C(C)CCC(C)(C)C</smiles> 


\section{EXPERIÊNCIAS EM EDUCAÇÃO ARTÍSTICA E DECOLONIALIDADE}

Ed. 


\section{EDIÇÃO}

Porto, Fortaleza, 2021

\section{i2ADS}

Instituto de Investigação em Arte, Design e Sociedade

i2ads.up.pt

\section{EDITORES}

Edite Colares, UECE

José Carlos de Paiva, i2ADS

COMISSÃO EDITORIAL

Edite Colares, UECE

Jeannette Filomeno Pouchain Ramos, UNILAB

José Carlos de Paiva, i2ADS

Rosália Menezes, UNILAB

\section{DESIGN}

Joana Lourencinho Carneiro, i2ADS

\section{ISBN}

978-989-9049-10-9

As imagens utilizadas são dos autores.

As ilustrações utilizam as pinturas rupestres na Serra da Capivara, Piauí - Brasil. 
Leão Lopes

INTRODUÇÃO

9-11
Ana Angélica Albano

TÃO LONGE, TÃO PERTO: DESAFIOS, RESISTÊNCIAS

E EMOÇÕES EM TEMPOS

DE PANDEMIA

$12-25$

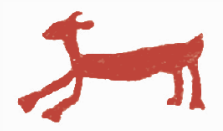

\section{REPENSAR AS EXPERIÊNCIAS ARTÍSTICAS FACE AOS DESAFIOS \\ DA DECOLONIALIDADE}

Ethel Batres

LA PARTITURA ES LA IRREALIDAD DE LA MÚSICA, ASÍ COMO LAS POLÍTICAS PÚBLICAS SON LA FICCIÓN DE LA EDUCACIÓN

$$
29-43
$$

Helber Rocha Rufino, Verônica Cabral da Silva CIRANDA NA ESCOLA: UMA PRÁTICA DECOLONIAL EM EDUCAÇÃO ARTÍSTICA

$$
44-52
$$

Ilda Lima de Sousa, Inês Cavaco

EDUCAÇÃO ARTÍSTICA E (DES) COLONIALIDADE: EXPERIÊNCIA NA COMUNIDADE QUILOMBOLA DE CONCEIÇÃO DAS CRIOULAS

$$
53-59
$$

José Carlos de Paiva

DESLOCAÇÃO DE SI E A INSCRIÇÃO EM PRÁTICAS ANTICOLONIAIS

$$
60-69
$$

Madalena Zaccara

APRENDER A OLHAR NOVAMENTE: MULHERES ARTISTAS BRASILEIRAS NA "ÉCOLE DE PARIS"

$$
70-77
$$

Rita Rainho

A INSURGÊNCIA DE UMA PLANTAÇÃO DE ALGODOEIRO HOJE: DOS TEMPOS DE MAGIA

ESCRAVA À RESISTÊNCIA CULTURAL PÓS INDEPENDÊNCIA EM CABO VERDE 
PRÁTICAS DE EDUCAÇÃO ARTÍSTICA NO CONTEMPORÂNEO

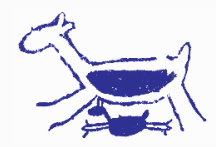

Edite Colares, Elaine Barbosa de Sales

MUSENCANTANDO: GRUPO

VOCAL E DE FORMAÇÃO

MUSICAL PARA EDUCADORES

$97-105$

Rosália Menezes

A POÉTICA DE GEGO:

TRAJETÓRIA LÚDICA

DE UMA LINHA

$106-113$

Francisco Harley de Oliveira

ENCANTARIAS DE FEIRA: ENCRUZILHADAS FÍLMICAS

$114-126$

Tiago Morais de Freitas,

Jeannette Filomeno Pouchain Ramos

REMINISCÊNCIAS

DA ANCESTRALIDADE NA FORMAÇÃO DOCENTE:

A INVENÇÃO DE UM MUSEU

COMUNITÁRIO

$127-142$

Lucimar Bello Frange

UM POMAR DE SONHOS, UMA PROPOSIÇÃO
Maria Aridenise Macena Fontenelle

ENGENHARIARTE RELATO DE EXPERIÊNCIA

$149-160$

Maria Kellynia Farias Alves

PRETAGOGIA: TRILHAS

NA PESQUISA E NA FORMAÇÃO AFRORREFERENCIADA

$161-167$

Núbia Agustinha Carvalho Santos

OUTRIDADE: O CORPO COMO POTÊNCIA DE ESCRITURA NA PERFORMANCE

$168-178$

Patrícia da Silva Martins

O ENSINO DO DESENHO COMO EXPERIÊNCIAS PRÁTICAS E CONCEITUAIS

$179-187$

Tânia Maria de Souza França,

José Álbio Moreira de Sales

HISTÓRIAS DE VIDA TECIDAS

COM ARTE E EDUCAÇÃO:

A EXPERIÊNCIA FORMATIVA DO

GRUPO DE PESQUISA IARTEH 


\section{Leão Lopes}

\section{INTRODUÇÃO}

Evocando René Magritte em Ceci n'est pas une pipe alerto o leitor que isto não se trata de um prefácio. Esta colectânea de textos de colegas professores de educação artística que me cabe inaugurar é antes de mais uma provocação para me tirar de um certo comodismo arquipelágico porque tenho tentado primar nos últimos tempos. Isto porque não tenho coisa a dizer que possa acrescentar aos trabalhos aqui apresentados: experiências relevantes no campo da Educação Artística que, afinal, me actualizam e despertam-me a considerações, muitas vezes questionáveis, a partir deste deserto de mar por onde eu me perco.

Esta colectânea é um encontro de amigos e companheiros com quem em várias ocasiões tive a honra de tomar parte nas reflexões e práticas educativas contemporâneas, produzidas por uns e por outros, em prol de uma educação artística mais sensível às transformações do mundo no nosso quotidiano.

Marcar presença aqui neste convívio é dever de cúmplice e de companheiro.

O tema deste encontro, em primeiro lugar, desafia-nos por associar a Educação Artística a uma dimensão política candente nos nossos países resultante de uma história colonial recente - a colonialidade - da qual não se sabe ainda como reverter o seu impacto social e político no nosso dia-a-dia, apesar de tantas revoluções inconsequentes, apesar de lutas armadas de libertação consequentes, apesar da ciência e do saber para dela nos libertar. Em segundo lugar exalta-nos por resgatar o debate que vem de longe sobre os mesmos desafios que se nos põem enquanto supostos agentes de mudança e renovação de paradigmas educativos que nos dizem respeito.

Confesso aqui um certo "desconforto" que me interpela, que suscita argumentação porque não sei como produzir um pensamento útil sobre uma realidade, intrínseca, fácil de questionar, mas difícil de produzir respostas convincentes no contexto onde me movo sendo eu próprio imbuído de valores e práticas culturais marcadamente coloniais. Diria mesmo, fortemente marcado tanto politicamente como administrativamente e, sobretudo culturalmente, por um eurocentrismo ancestral apesar de minha identidade híbrida, "cafrealizada" por outros elementos que entraram na química de minha génese cultural. Poderia apresentar-me como inocente, mas a verdade é que não sou, sou antes cúmplice e agente de valores que combato mas, qual D. Quixote, a guerra, inglória, só se realiza em mim. 
Referi acima ao desconforto do apêndice "decolonialidade" associada à educação artística. Volto a ele porque ainda não sei bem onde encaixar a noção de "colonialidade" no meu caso, no caso cabo-verdiano na óptica da corrente mais vulgar e mais estudada do colonialismo, ou seja eurocêntrica, monolítica: ou seja a da ocupação, apropriação e "contaminação" por vezes violenta de uma cultura endógena por parte de uma outra "alien", desconhecida, sabendo, contudo que essa "contaminação" instala-se muitas vezes em paz, a autóctone negoceia, incorpora, integra, "canibaliza", criouliza, não se importando com a resultante cujos elementos que entraram na sua composição já não se distinguem dela. É o nosso caso, é o meu caso. A colonialidade decorrente da colonização no plano político e administrativo, embora se instale transversalmente na vida de uma civilização autóctone, encontrada, é bem diferente da abordagem da mesma noção (neste meu caso) especialmente no plano da cultura e da educação. Também da Arte. Espaços que pressupõe noções de liberdade, de assimilação pacífica, de rejeição e de incorporação do outro. De igualdade. A sua resultante neste particular só pode ser estudada e reflectiva com serenidade se pudermos ver o fenómeno de uma perspectiva histórica e dialética, divergente. Por exemplo, da perspectiva de quem supostamente é pervertido, alienado, violentado. No caso cabo-verdiano, de sua identidade-raiz, não será fácil sustentar a noção do colonialismo como é habitual perceber-se. Há-que considerar que o outro chegou a território de ninguém. Serão "outros". Nestas ilhas, sem história, sem cultura, sem identidade, deu-se uma "instalação natural", uma apropriação donde nasceria um novo episódio histórico, uma nova cultura, uma nova resultante de identidade(s)-raiz que a conformaram. Vinda do mar e doutras geografias. Sem qualquer outra possibilidade senão a da criação ou invenção de uma nova identidade, novos hábitos, novos costumes, nova língua, novas formas de negociar, novos modos de vida. Híbridos, todavia. Impostos por elementos que não seriam outros que os da insularidade, da natureza ecológica do meio, da utopia e da vontade e estranha determinação humana em se realizar em meio a adversidades de toda a ordem.

Embora território de ninguém, ocupado pelos que chegaram e dele fizeram seu, o que nas ilhas se instalou de facto foi bem diferente do que veio a tomar-se como resultante noutros territórios, com culturas autóctones, ancestrais. A resultante hoje -, onde colonialidade e decolonialidade enquanto questões de política e de poder exógenos - deverá ser particularmente estudada nos planos referidos (história, cultura, identidade-raiz), campos do saber e do ser.

O campo da Educação Artística e seu projecto educativo terá um espaço de actuação sui generis nessa nova epistemologia decorrente da colonização. Mas teremos que ter em conta a sua missão de "campo" que é questionar sem sancionar, despertar para melhor sentir, actuar como princípio de aprendizagem. Será nesse campo que melhor poderemos entender, para desconstruir e aprender, a idiossincrasia de culturas inclusive aquelas que se apropriaram pacificamente do aport do outro sem qualquer necessidade de o questionar. 
É aqui que o eurocentrismo, a decolonialidade intrínseca a processos outros, não deverá ser questionado fora de uma matriz cultural que já o integra desde a sua fundação e que a absorve ideologicamente e politicamente com todas as suas consequências. Os modelos de organização social, os suportes constitucionais das nações resultantes, os paradigmas do desenvolvimento desenhados, emanados e financiados pela mesma matriz - eurocêntrica - são pacificamente absorvidos e transferidos para uma realidade que esta, sim, acaba por se tornar refém de uma epistemologia assente "irremediavelmente" na história do colonialismo ocidental.

Qual será o papel da Educação Artística neste emaranhado contexto cultural e histórico. Onde o outro conta em nós, onde é necessário promover as condições e sentidos para uma outra ordem de pensar, de questionar, de experienciar o mundo? Qual poderá ser o papel do novo educador consciente dos desafios de hoje que não serão tão diferentes dos de ontem? Como deverá proporcionar a crianças, adolescentes e adultos com quem interage oportunidades de pensar o futuro interpelando a história e questionando criticamente o presente nas suas dissimetrias sociais e económicas? Se os meios e os instrumentos teóricos que vimos repetindo ainda nos parecem eficazes, não creio que estejamos desatentos à necessidade de os adequar e, ao papel da educação, às questões candentes porque vive o mundo de hoje: a pobreza extrema de mais que muitos de nós; as perseguições e aniquilamento do divergente e do particular; o capitalismo desenfreado a implantar-se doidamente em países pobres cada vez mais cativos de um novo e escandaloso sistema financeiro mundial; a liberdade e a soberania das nações menos influentes impiedosamente esmagadas sob a pesada bota hegemónica dos donos da tecnologia e do capital mundial; a negação do direito a existir com o mínimo de dignidade de grande parte da humanidade; a sonegação do direito à boa educação e bem estar de toda a criança; o medo de uma parte da humanidade sobre a outra parte, enfim...

Qual será o papel da Educação Artística neste mosaico de problemas que o mundo, hoje, nos oferece? Não saberei responder, embora esta questão, empurrando um grande ponto de interrogação à frente, me vem perseguindo há muito tempo. Às vezes penso que deveríamos suspender até ver o adjectivo desta educação. Dar um tempo sabático às tendências que vêm de longe e que limitam o campo da educação dos sentidos que será preciso e urgente restaurar. De todos os sentidos. Desde o tacto ao cheiro. Para nos prepararmos melhor a sentir o mundo e suas complexidades também pelo cheiro. Pelos sinais que andam no ar, pelo toque que as injustiças deste mesmo mundo deveriam produzir em nós em modo de indignação à flor da pele, de forma a suscitar acções e resultasse de imediato nas mudanças necessárias para um novo existir. Sem medo. Eis o que me parece ser uma educação que pretenda ser futuro. E se a Arte estiver por aí, tanto melhor!!

Aprendi muito com as experiências aqui insertas; algumas ensaiando uma nova abordagem metodológica do ensino artístico em contextos culturais divergentes, e matriz (colonial) comum; todas de uma forma ou de outra reclamando um novo 
pensamento crítico e de acção nesse campo. Isso me conforta e traz uma nova esperança ao futuro do ofício e novos sentidos de labor. Trazer a EA para o campo dos problemas reais das pessoas, sejam sociais sejam políticas, será imprimir-lhe a dimensão epistemológica que lhe cabe e ao seu sentido de missão enquanto campo do pensamento e de aprendizagem que se dirige, por isso, às pessoas e seus problemas, à comunidade cultural a que pertencem. Também ao campo da política para poder questionar por dentro o seu papel e o papel do Estado nas políticas educativas e culturais e na vida da sociedade que representa e gere.

José Paiva no texto inserto nesta colectânea exalta essa dimensão e compromisso político, hoje, indissociável da missão do "educador". Nele, sublinha que hoje pode ser um tempo de reconfiguração necessária dos processos educativos, de que somos também actores e aprendizes, de forma a confrontar discursos e práticas educativas reprodutores de ideais e desígnios de poder que queremos combater. Acredito que será este, esta urgência de luta corpo a corpo com o estabelecido, também um desígnio de cada um de nós embora contaminados pelo objecto de nosso combate. Que não se esgota no eurocentrismo, mas que também se expressa noutros "centrismos" às vezes respondendo tacitamente a estratégias ideológicas e culturais específicas não menos questionáveis que o que nos traz aqui à confronto e à discussão. Já lá vai o tempo em que o nosso confronto à colonialidade foi contrapondo-o com a "africanização dos espíritos". Com um outro "centrismo", considerando a ingente necessidade de nos libertarmos daquilo que nos é intrínseco, irremediavelmente: das marcas mais profundas e negativas do colonialismo. Marcas essas constituintes de nossa identidade resultante que, suprimidas, seriámos obviamente outras. Melhor, talvez. Mas não nós, exactamente. O que não sabíamos então é que não há volta a dar à História, mas haverá sempre a possibilidade de a recriar, de vê-la sob outro ângulo e de a reinterpretar, hoje. Eis a oportunidade deste nosso "tempo de transformação e reconfiguração necessária" na óptica de José Paiva.

Estando absolutamente de acordo com essa visão e paradigma de conformação do futuro da educação, o problema que se me põe é o papel do Estado, regulador, ideologicamente centralizador, programador e financiador de um sistema cujos próprios promotores "tempo de transformação e reconfiguração necessária" dele dependem. Como conciliar esse paradoxo sem considerar a possibilidade de um "golpe Estado" epistemológico? É claro que rupturas e acções de "guerrilha" vêm-se dando - veja-se o exemplo destes encontros "marginais" -, mas a verdade é que a luta é francamente desigual.

A contribuição de Ethel Batres, inaugural neste volume, relata o processo de colonização sobre culturas e povos originários (no caso da América Latina) que se estendem a casos no Continente Africano, acrescento, coincidentes em tempo histórico, em origem e cultura colonial. Retrato de um processo ainda vigente no contemporâneo que será da máxima importância analisar e discutir do ponto de vista interno, do ponto de vista da resultante desse processo. Aliás, a autora recorre 
a Aníbal Quijano para nos lembrar que a perspectiva eurocêntrica não pertence exclusivamente aos europeus ou às forças dominantes do capitalismo mundial, mas sim a "nós" que fomos educados sob seus valores culturais, hegemónicos. E, diria, que só a nós cabe a determinação de destrinçar até onde somos aquilo que negamos ser, intrinsecamente e irremediavelmente um outro que não é, todavia, aquele de há quinhentos anos. Mas um outro de hoje com todos os outros de ontem dentro de nós.

Subscrevo na íntegra a lembrança de Aníbal Quijano como deverei ter feito perceber.

Em Cabo Verde, tal como na Guatemala, conforme nos dá conta Ethel Batres, o paradigma do desenho curricular é também monopólico, hegemónico e impositivo. Decorrente obviamente de um "processus" que atrás tentei esboçar. Pela mesma razão as mudanças radicais são inviabilizadas operando nos centros de decisão resistências políticas que protelam mudanças e bloqueiam espaços de diálogo ou oportunidades de discussão que possam introduzir a necessidade de "reconfigurações necessárias" ao sistema educativo.

O que nos sobra é a possibilidade de "insurreição" nalgumas frentes marginais e mesmo nelas o confronto se dá apenas no plano da utopia, não se vislumbrando a possibilidade de uma perversão de dentro do sistema que possa produzir, experimentar e operar essa vontade de mudança. Lamentavelmente. 


\section{Ana Angélica Albano, Sérgio de Azevedo e Laura Lydia TÃO LONGE, TÃO PERTO: DESAFIOS, RESISTÊNCIAS E EMOÇÕES EM TEMPOS DE PANDEMIA}

Te olhava de longe. Te queria por perto.

Clarice Lispector

Era 24 de maio de 2016 quando aterrizei pela primeira vez em Puerto Montt no sul do Chile. Viajava a convite da Universidad de Chile para fazer a Conferencia Magistral do Seminario de Educación Artística, evento da Semana de Educação Artística convocada pela UNESCO.

Foi a primeira de muitas viagens ao Chile a trabalho.

Se inicio minha reflexão rememorando esta conferência é pela interlocução profundamente emotiva, quase mágica, com os participantes, borrando fronteiras e distâncias linguísticas. Uma comunicação que deu início a uma parceria de trabalho com o professor Sergio Trabucco (Universidad de Chile, atualmente na Universidad de Los Lagos), que dura 4 anos, envolvendo alunos e professores de escolas rurais de Chiloé, seminários em Santiago e comunicações conjuntas em congressos internacionais. Não fosse a pandemia, teria participado, novamente, em maio deste ano do Seminario de Educación Artística da UNESCO, na Região de Los Lagos.

Longas viagens para participar de eventos, nacionais e/ou internacionais, fazem parte da docência universitária e, confesso, desfruto imensamente a possibilidade dos encontros e parcerias de trabalho que proporcionam.

A comunicação que se estabelece na relação direta com os participantes de uma conferência ou com alunos numa sala de aula, o contato olho no olho, é insubstituível e espero, ansiosamente, a possibilidade de retomá-la.

Gosto da oportunidade de modular meu discurso pela reação dos espectadores, escutar os silêncios, perceber os espantos, as dúvidas e as descobertas estampadas nos olhares na platéia. 
Para mim não é fácil falar para pessoas, que nunca saberei quem são e onde estão, através da câmera de um computador. Tenho resistido e recusado a maior partes dos convites para participar de lives. $\mathrm{O}$ isolamento constelou em mim o arquétipo do ermitão, confiscou minhas palavras e o silêncio me parecia a única opção possível.

No entanto, depois de oito meses de isolamento, observando experiências de aulas, mesas redondas e conferências remotas, começo a refletir que pode haver proximidade na distância.

Lembrei-me, então, de uma observação do professor Pethö Sándor1, alertando-nos que em tempos de crise é importante ficarmos atentos às oportunidades: "quando muitas portas se fecham, algumas janelas se abrem. Fiquem atentos, pois se não olharem através das novas brechas, perderão as possibilidades que apresentam...”

Percebo o ensino remoto removendo fronteiras e possibilitando formas de tocar pessoas fora do nosso círculo imediato. Nem sempre saberemos como e quanto estas pessoas foram tocadas. De qualquer forma, mesmo nas atividades presenciais, sabemos apenas o que dissemos, nunca o que o outro ouviu.

A Conferência de Puerto Montt de 2016 foi assistida por aproximadamente 200 pessoas, que podem ter comentado com outras tantas, mas a experiência ficou restrita àquele grupo.

Em 12 outubro de 2020 mediei uma mesa redonda no Zoom, veiculada no Youtube, com três artistas - Edith Derdik, Paulo Pasta e Guto Lacaz - autores dos livros Linha, Cor e Forma, da coleção Viu, lançada do Instituto Arte na Escola2.

Centenas de pessoas, do Brasil e do exterior, assistiram à mesa online, participando do debate em tempo real, mas o evento não terminou ali. Depois de um mês continuo recebendo comentários, o vídeo já registrou mais de 3900 acessos e, possivelmente, continuará sendo acessado por algum tempo.

Foi com surpresa e muito prazer que recebi mensagem, de um amigo cientista residente na California, comentando a coleção Viu. Ele, provavelmente, nunca teria assistido uma mesa redonda sobre livros de arte para crianças não fosse a pandemia e a facilidade de acesso ao Youtube.

Nunca estivemos tão isolados, tão distantes...e tão próximos.

A distância está criando formas de aproximação, que nós, professores de arte, sempre olhamos com desconfiança, descrentes da possibilidade de aulas online. Não acreditávamos ser possível aulas remotas de artes visuais, muito menos de artes corporais e cênicas, que são essencialmente coletivas.

\footnotetext{
${ }^{1}$ Pethö Sándor (1914 -1992), médico obstetra e neurologista húngaro, que veio para o Brasil em 1949. Foi professor na Faculdade de Psicologia da PUC de São Paulo. Em 1982, iniciou no Instituto Sedes Sapientiae de São Paulo, o Curso de Especialização "Psicoterapia de Orientação Junguiana Coligada a Técnicas Corporais" que conduziu até 1991.

${ }^{2}$ Instituto Arte na Escola, vídeo de Lançamento da Coleção Viu - LINHA, COR e FORMA - Criação de Imagens na Infância. Disponível em https://youtu.be/bX6p44uFGzQ
} 
Obrigadas pelas circunstâncias escolas e universidades tiveram que descobrir formas de atender às exigências curriculares, implementando, da noite para o dia, aulas de arte à distancia. Acreditando, ou não, no ensino de arte remoto, docentes tiveram que se reinventar e estudantes, querendo, ou não, foram obrigados a participar.

Recebi, e continuo recebendo, mensagens de ex-alunos relatando suas experiências com aulas online. Escuto dores, surpresas e descobertas.

Diante das muitas perdas que estamos vivendo na pandemia, começo a vislumbrar alguns ganhos, algumas janelas se abrindo, descortinando novos horizontes.

Faço, então, um convite para olharmos através de duas janelas que tive o privilégio de acompanhar o movimento de abertura.

A primeira nos apresenta, à primeira vista, uma cidade industrial: São Caetano do Sul, que, paradoxalmente, é conhecida pelo ensino de arte de excelência. Criada em 1968, a Fundação das Artes ${ }^{3}$ é uma das instituições mais antigas dedicadas ao ensino de arte, em contínua atividade, no Estado de São Paulo.

A Fundação que, tradicionalmente, atende alunos da região do $\mathrm{ABC}$ e adjacências começou a receber pedidos de matrícula de diversas partes do Brasil, quando obrigada a oferecer aulas online. E professores descobrem que podem navegar por mares nunca dantes navegados...

Para adentrar a paisagem desta janela seremos guiados por Sérgio de Azevedo, professor da Escola de Teatro e coordenador adjunto dos cursos de formação inicial e continuada da FASCS.

A segunda janela mostra a cidade do Rio de Janeiro e ajustando o foco vemos o ateliê livre Capacete4, onde a artista Laura Lydia trabalha com crianças.Vemos meninos e meninas criando esculturas. Logo vemos as mesmas crianças, cada uma em sua casa, criando novas esculturas. Mesmo não sendo obrigadas por nenhum currículo oficial, optaram continuar as aulas remotas. Ficamos sabendo que os pais incentivam as atividades, as primeiras que seriam naturalmente cortadas em tempos de crise. Vemos crianças de outras cidades frequentando as aulas do ateliê, agora online. Através de muitas fotos e algumas observações, Laura Lydia nos conta como tornou possível aulas remotas de artes visuais.

\footnotetext{
${ }^{3}$ A Fundação das Artes de São Caetano do Sul (FASCS) é uma instituição de ensino e pesquisa em artes que oferece cursos livres e técnicos nas linguagens de Artes Visuais, Dança, Música e Teatro e programas de iniciação, qualificação e formação profissional na área da cultura.

${ }^{4} \mathrm{O}$ Ateliê Capacete é um espaço de arte que desenvolve projetos e residências artísticas há 20 anos, recebendo artistas de diversas partes do mundo. Desde 2018 o projeto de aulas de arte de Laura acontece no local, que abriga também seu ateliê.
} 


\section{CAMPO AMPLIADO DE IMAGINAÇÃO \\ Sérgio de Azevedo}

Após oito meses de distanciamento social, sinto-me exausto e ansioso como nunca me senti, resultado das muitas horas diante da tela e da falta que sinto dos encontros presenciais que permeiam minha atuação como professor e gestor cultural.

Semanas após o início das aulas remotas, encerrei uma transmissão com meus alunos do curso de teatro e, em seguida, chorei como não chorava há tempos. Tinha sido uma semana ruim, com aulas insossas e encontros acinzentados. Sentia-me exausto, triste, como um comandante que assistia, atônito, seu navio afundar.

Quando participei, a convite de Alessandra Ancona, de minha primeira live, verbalizei algo que se tornou um fio condutor pessoal em tempos pandêmicos: "Sinto-me tomado, diariamente, por pulsões de vida e por pulsões de morte. Eu escolhi viver a pandemia me focando na primeira, sabendo que a segunda sempre estará presente".

E assim tem sido: com a alma entristecida decidi seguir, instante a instante, de mãos dadas com a vida (e seu potencial criador) ao mesmo tempo em que buscava integrar as mortes que habitavam meu íntimo.

Como professor sentia que, ao ser arrastado pela correnteza, tentava manter-me agarrado aos alunos. Alguns perdi, levados pela falta de conexão e problemas de acesso à internet; outros sugados por ambientes domésticos tóxicos que não abriam espaço para a expressividade de seus corpos e vozes; outros, ainda, tomados pela frustração. Foi doloroso acompanhar a tristeza de uma turma que trabalhou meses em um espetáculo que estrearia 14 de março, um dia após o fechamento da cidade. Espetáculo este que nunca ocorreu.

Ao mesmo tempo, encontrei beleza em pequenas coisas: ao acessar à casa dos estudantes e permitir que conhecessem um pouco da minha; ao conhecer familiares que apoiam o estudo da arte; ao presenciar os esforços de muitos para se manter em um processo conjunto de aprendizado. Eu e meus alunos transbordamos por telas e descobrimos modalidades de (tele)presença que não imaginávamos criar e partilhar. Comecei a perceber emoções similares às que vivencio presencialmente.

Em nenhum momento me interessou o debate se o que estávamos fazendo era teatro ou não. Preferi me dedicar à manutenção de vínculos por meio do trabalho artístico e pedagógico e, assim, buscar outras e novas possibilidades expressivas, assumindo os processos como campos de experimentação, sem necessitar dar nome a eles. Isso quebrou algumas de minhas certezas, flexibilizou procedimentos e abriu lacunas para um novo "ser-estar" em aula.

Arrastado por uma correnteza que não se controla, hoje reflito acerca de algumas das decisões tomadas. A mais acertada foi a de não interromper o processo formativo, mantendo, com pequenos ajustes, o calendário. Como resultado, seguimos com as aulas, inventamos projetos como o Festival Cenas para um Futuro Próximo e 
fizemos nossa Mostra semestral, mantendo a escola viva em nossas casas e em nossas práticas. Como resultado disso, pude estabelecer diálogos e aproximações com autores, como fiz como Yolanda Serrano Meana. Vi um corpo docente unir-se em suas diferenças. Surpreendi-me diante do fato da produção da escola ser assistida por um público dez vezes maior do que tem ocorrido presencialmente; soube de famílias de alunos que passaram a debater cenas dos experimentos nos grupos de WhatsApp da família - campo que nunca tínhamos conseguido adentrar.

Como gestor, vivi outros desafios e emoções. Estava previsto para o final de março o início das aulas de 25 turmas que atenderiam mais de 500 estudantes dos cursos presenciais de agente cultural, cenografia, dança, dramaturgia, figurino, maquiagem, recreação e produção cultural. Previsão que, obviamente, não se concretizou. E à medida que avançávamos, era nítido que não retornaríamos tão logo quanto se imaginava. Novamente a sensação de sermos arrastados pela correnteza. Iniciamos ou não as turmas? Digamos que não tomamos nenhuma decisão. Ela é que nos tomou, uma vez que ou iniciávamos a oferta ou a instituição teria que devolver os recursos para o Governo Federal. Como esta última nunca foi uma opção, bastou aceitar que o ensino remoto era inevitável.

Foi um tremendo desafio gerenciar uma equipe nova, com 27 pessoas, de forma remota e dar conta das mais de 4.000 inscrições que recebemos. O fato é que com todos os contratempos imagináveis e inimagináveis, o programa foi iniciado e tem prevista uma mostra processual a ser realizada em dezembro, inteiramente virtual.

A roda de emoções como gestor, tal qual a do professor, girou. De todas os desafios e conquistas, quero tratar de duas situações que ilustram as possibilidades que a pandemia fez emergir. A primeira diz respeito a uma turma não planejada.

Analisando o perfil dos inscritos, notei que mais de $20 \%$ dos interessados residiam fora da Região Metropolitana de São Paulo, inclusive em outros estados. Notifiquei os alunos, destacando que nosso curso era presencial e estava sendo ofertado de forma remota apenas provisoriamente. A instituição sequer tinha autorização para cursos na modalidade EaD.

O planejamento que previa inicialmente 25 turmas começou a mudar quando respostas chegaram. Vindas de longe, chamaram a minha atenção. Uma delas, do Amazonas, foi a que mais me tocou, a ponto de me emocionar. Especialmente pela maneira sensível que foi redigida. Era um pedido para o qual o coração encontra dificuldades de dizer não. De repente, Manaus me parecia tão perto...

A semente da mudança foi plantada. A partir daí, deparei-me com um desafio: como viabilizar um curso para os alunos de longe? Iniciei, sem muita convicção de que seria bem-sucedido, um percurso que envolveu as equipes de gestão da Fundação das Artes e do Ministério da Educação. Ao invés de resistências, encontrei ressonâncias. No caminho, um insight: não poderíamos ofertar turmas na modalidade de ensino à distância (tão definida por regras e exigências que não poderíamos cumprir), mas, por conta da pandemia, poderíamos oferecer, até dezembro, cursos remotos. 
Após dialogar com docentes de dramaturgia e supervisores, encontrei mais possibilidades de viabilizar a proposta. Em duas semanas, formamos a $26^{\mathbf{a}}$ turma, chamada de F26, composta por estudantes de 11 estados de todas as regióes brasileiras. Pessoas de cidades como Belo Horizonte, Curitiba, Fortaleza, Manaus, Recife, Rio de Janeiro, Salvador, São José de Ribamar e Tucano, dentre outras, passaram a compartilhar um espaço comum criado pelas possibilidades tecnológicas. Sem planejar, a instituição que antes atendia apenas estudantes de seu entorno territorial no Grande $\mathrm{ABC}, \mathrm{SP}$, começou a ouvir vozes e sotaques, em suas salas virtuais, advindos de vários lugares do Brasil.

A percepção de que algo acontecia ao compartilharmos nossas casas e ocupá-las como nova sede de nossa escola, tão cara a mim como professor, também era importante para outros. Como apontou Diego Cardoso, um dos três docentes da turma, "com a F26, percebi que havíamos conquistado uma proximidade (eu com eles, e o grupo entre si) que sanou várias dessas questões e desafios do ensino remoto. (...) As aulas eram (...) espaços de encontro nos quais dúvidas e desejos eram compartilhados (...) e as pessoas ganhavam intimidade. Víamos as casas uns dos outros, os trajetos de volta do trabalho, as máscaras penduradas no porta-chaves, os gatos, os barulhos da família".

Algo que é compartilhado por um dos alunos da turma, Ruan Rocha, "o diálogo com diferentes traços culturais, sotaques, discursos e olhares é fundamental para um bom dramaturgo. (...) Histórias vindas de lugares tão diferentes tem sido uma verdadeira inspiração."

Outro aluno da turma, Alexandre Magno, do Rio de Janeiro, destacou um ponto que tenho percebido ao longo da pandemia - a necessidade de ouvir e de se criar outra forma de diálogo em grupo: "Um dos primeiros aspectos que destacaria é a intensidade, que advém de uma escuta mais expansiva. A modalidade remota nos exige ouvir mais, ouvir diferente. A partir daí decorre também uma escuta também imagética".

Outra experiência que destaco foi uma ação que surgiu a partir da ideia de Robson Ferraz, supervisor pedagógico: criar encontros semanais para conversarmos com pessoas de várias partes do Brasil e do mundo. Como resultado disso, pudemos debater com artistas residentes em diferentes localidades, inclusive nas Filipinas, Irlanda e Costa Rica. Ao ouvir, por exemplo, o relato de Den Ramonal, artista da dança, percebi muitos pontos de conexão entre o que se vive nas Filipinas e no Brasil.

A pandemia evidenciou o que não sabíamos: que tínhamos condições para oferecer um curso de arte à distância. Mostrou que Tucano, na Bahia pode fazer divisa com Curitiba, no Paraná ou Manaus, no Amazonas. E o Brasil pode fazer aproximações imaginadas com países territorialmente distantes.

Alfons Martinell, gestor e docente da Universidade de Girona, diz que um gestor cultural deve ficar atento ao que é dito e, também, ao que não é dito. Sempre achei poético e desafiador ficar atento ao que não era dito. Contudo, as experiências 
aqui relatadas me ensinaram que, às vezes, ouvir o dito (inesperado) também nos possibilita acessar o que até então era desconhecido.

$\mathrm{O}$ artista-gestor-educador que sou e que seguiu o fio condutor da pulsão de vida é diferente daquele que adentrou à pandemia. Ainda é cedo para conclusões. Contudo, sinto que algumas certezas se foram, como a que eu tinha acerca das limitações do ensino à distância. Tenho ressalvas, mas fui apresentado para novas possibilidades expressivas que hoje compõe meu processo de criação.

Além disso, passei a me interessar pelo que tenho chamado de universo expandido ou campo ampliado de imaginação - ações que nascem nas práticas cênicas e que encontram possibilidades de expansão por meio das redes digitais e recursos tecnológicos. Experiências que inventam aproximações entre pessoas, entre cidades e que podem criar pontes para ligar o que estava distante.

\section{DAS MICROPOLÍTICAS DO AFETO - A TELA É A JANELA}

\section{Laura Lydia}

Depois de duas semanas de aulas presenciais no ateliê, fomos forçados a interromper os encontros sem saber por quanto tempo...

Escrevi mensagens para cada grupo, com sugestões de criação e palavras de afeto, buscando manter o vínculo e assimilar a nova condição.

Num movimento forte de sintonia entre os desejos e as necessidades de todos, os pais começaram a me escrever e nos perguntamos como poderíamos fazer para seguirmos com as aulas.

Resolvi experimentar duas frentes: vídeos de aulas gravadas e encontros online. Gostei da experiência de filmar e me comunicar desta forma, mas logo percebi que fazia mais sentido o encontro para pensar e criar arte juntos, ainda que através das telas.

Adiamos os planos de esculpir com cimento aerado e madeira, assim como, pintar em grandes suportes e experimentar outros formatos e materialidades. Optei por garimpar materiais dentro do ambiente doméstico: cabides, tecidos e roupas, linhas e barbantes, papéis, materiais da natureza, sabão, embalagens descartáveis. Foram (e ainda são) muitas as possibilidades e as experiências, sempre com o foco na investigação criativa e no compartilhamento de dúvidas e descobertas.

A riqueza desses encontros e, mais recentemente, com as novas turmas online que abri ao longo dos meses, se fortalece no encantamento da partilha sensível, tornada possível pela confiança e pelo vínculo que estabelecemos.

Não tenho como trocar olhares e perceber certas sutilezas, ou segurar o papel junto com a criança para ajudá-la a resolver algum problema técnico com minhas próprias mãos. Muitas vezes, inclusive, ela não encontra a solução que buscava naquele momento, mas segue presente, construindo seu caminho poético, manuseando materiais, narrando histórias e processos para mim e para os colegas. 


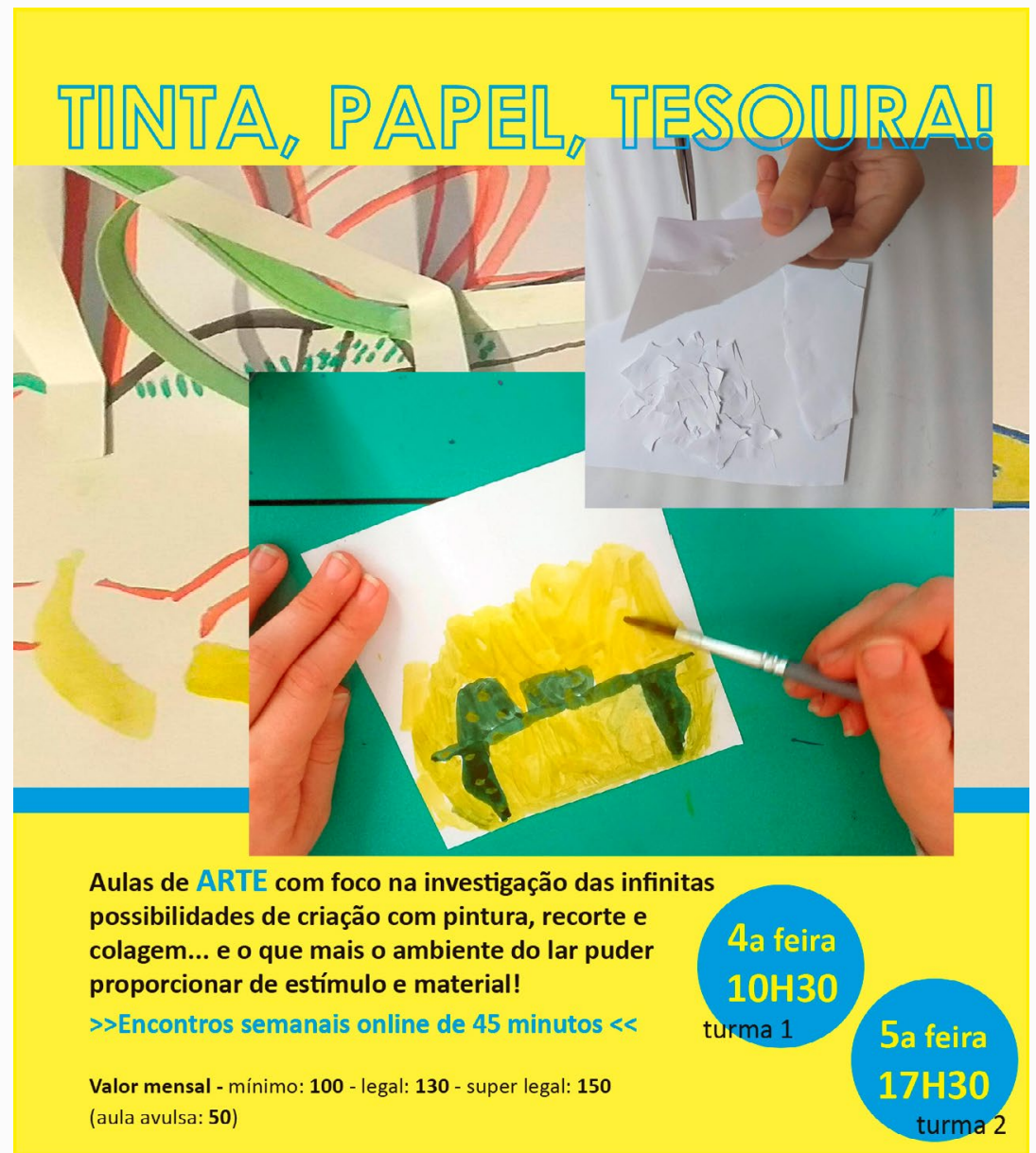


"Essa aula, mãe, é para dar asas à imaginação", disse Tomás, 7 anos, logo depois da chamada terminar.

"Meu filho tinha muito medo de desenhar. Com você, ele se sente livre para criar, trazendo respostas simples e tão lindas, cheias de histórias!”, contou-me uma mãe.

E uma outra, ainda, narra que sua filha de 13 anos passa a semana inteira aguardando ansiosamente pelo encontro.

Sempre que possível comunico-me com mães e pais depois das aulas, assim como fazia quando iam buscá-las no meu ateliê. Importante trocar impressões vindas do lado de cá e de lá da tela/janela. Histórias e emoções materializadas ora na cozinha, ora no quarto, no quintal ou na sala de cada casa. Embora em outros bairros, cidades e até estados e países... estamos juntos. As distâncias diminuíram?

As portas das casas se abrem e a permissão para criar acontece. $\mathrm{O}$ encontro consigo mesmo e com o outro torna-se possível pela escuta sensível deste momento que tanto pede afeto e poesia.

\section{ONDE OS HORIZONTES SE TOCAM...}

O que cura é o contato afetivo de uma pessoa com a outra.

O que cura é a alegria, o que cura é a falta de preconceito.

Nise da Silveira

Em tempos de pandemia há que se buscar espaços de acolhimento.

Dra. Nise da Silveira costumava dizer que "o monitor, num atelier ou oficina, funciona como uma espécie de catalizador" ${ }^{\prime}$, cuja presença afetiva acelera os processos de criação.

Ao contrário do que temíamos, o ensino remoto não dispensou, nem diminuiu a importância do professor. O isolamento evidenciou a necessidade de vínculos, de parcerias que nos ajudem a superar distâncias, expandir repertórios, projetando nova luz na imagem do educador.

“....o coração do educador deve desempenhar uma tarefa cuja importância mal poderemos avaliar devidamente. Recordamos com reconhecimento professores competentes, mas sentimos gratidão em relação àqueles que se dirigiriam ao nosso íntimo. A matéria do ensino se assemelha ao mineral indispensável, mas é o calor que constitui o elemento vital que faz crescer a planta e também a alma...”

${ }^{5}$ SILVEIRA, Nise. Imagens do Inconsciente, Rio de Janeiro, Alhambra, 1982, p. 68.

${ }^{6}$ JUNG, Carl Gustav. O Desenvolvimento da Personalidade, Petrópolis, Editora Vozes, 1981, p. 149. 

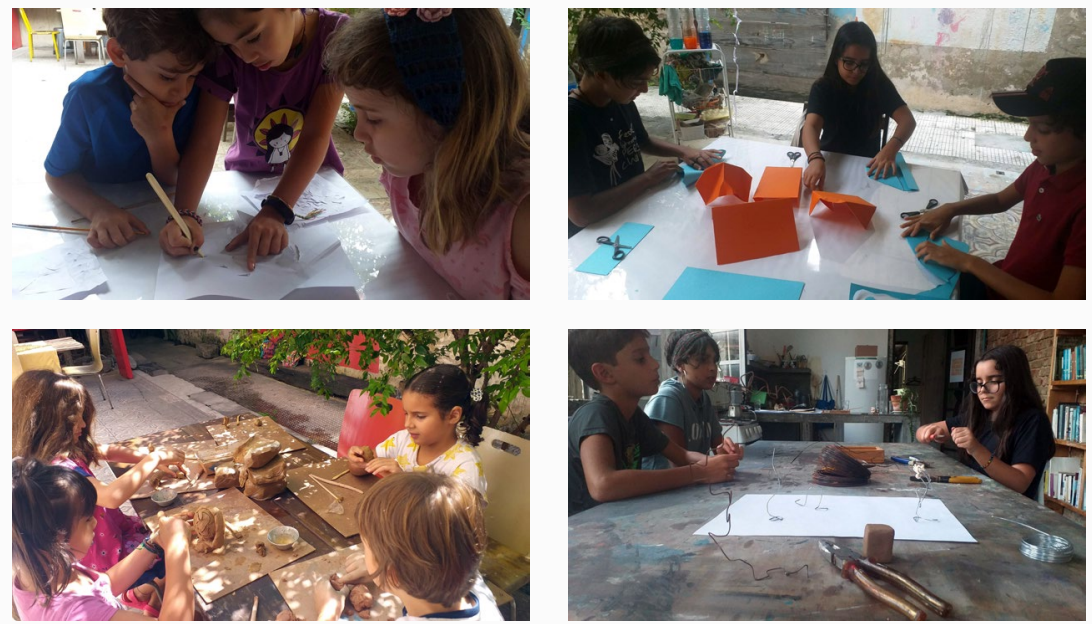

Aulas presenciais no ateliê.
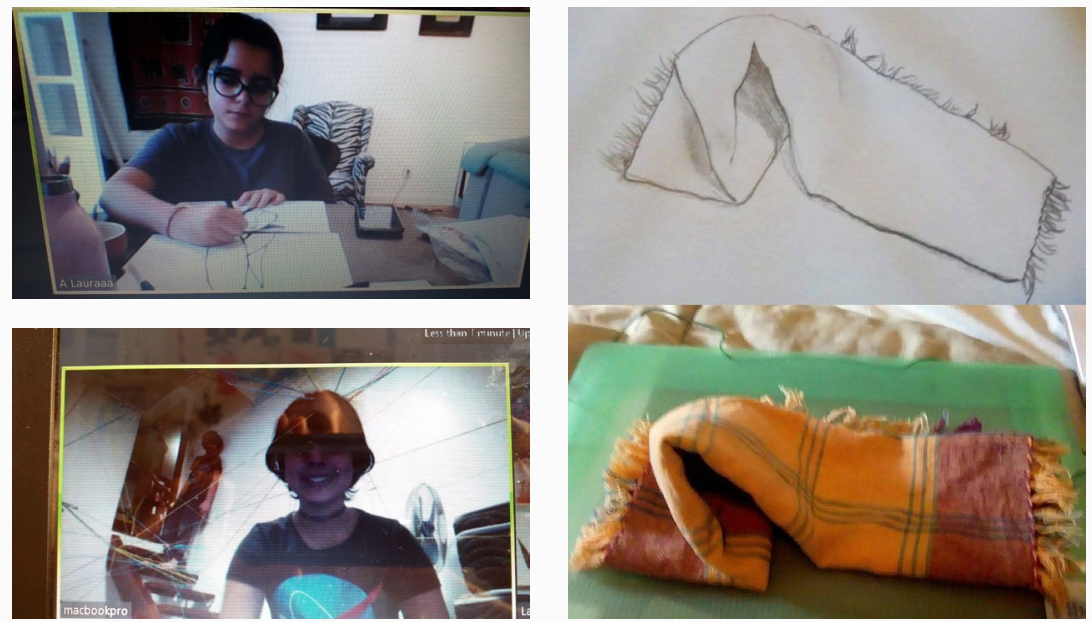

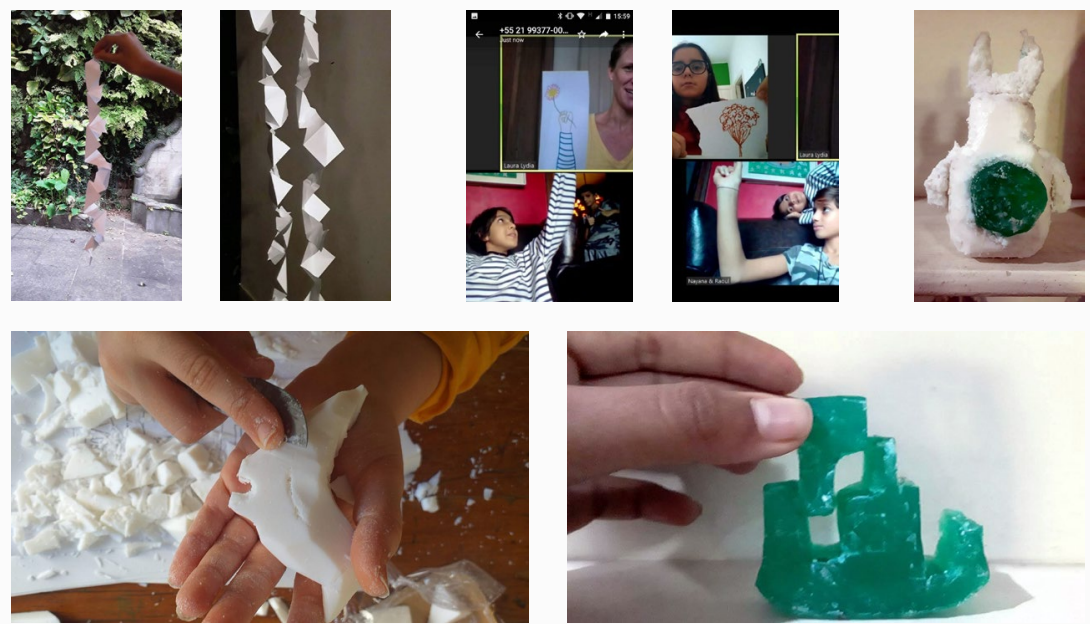

Aulas de escultura online.
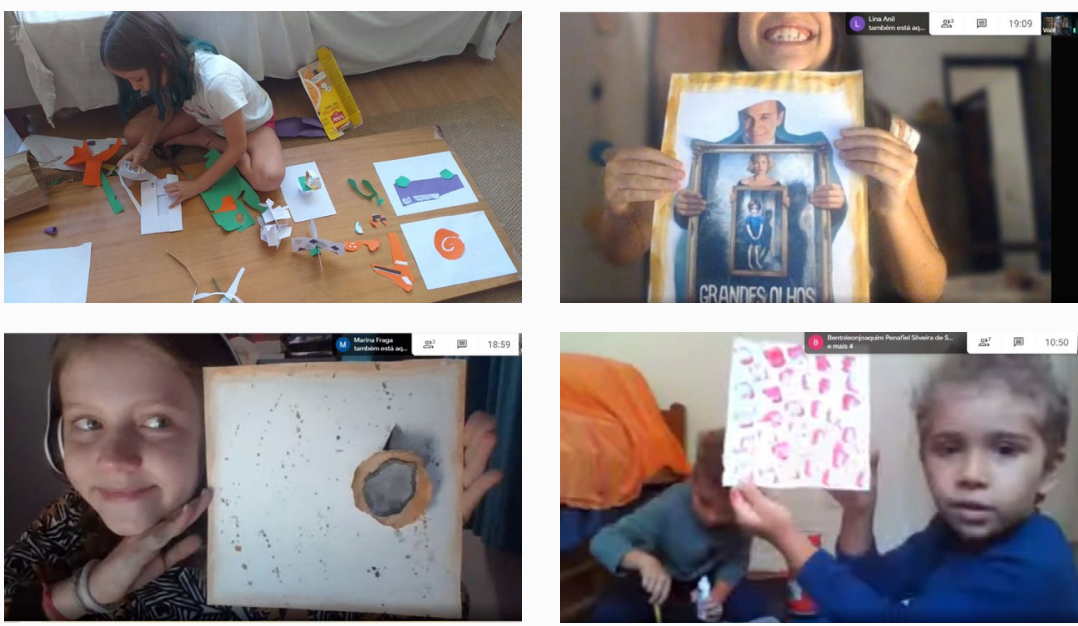

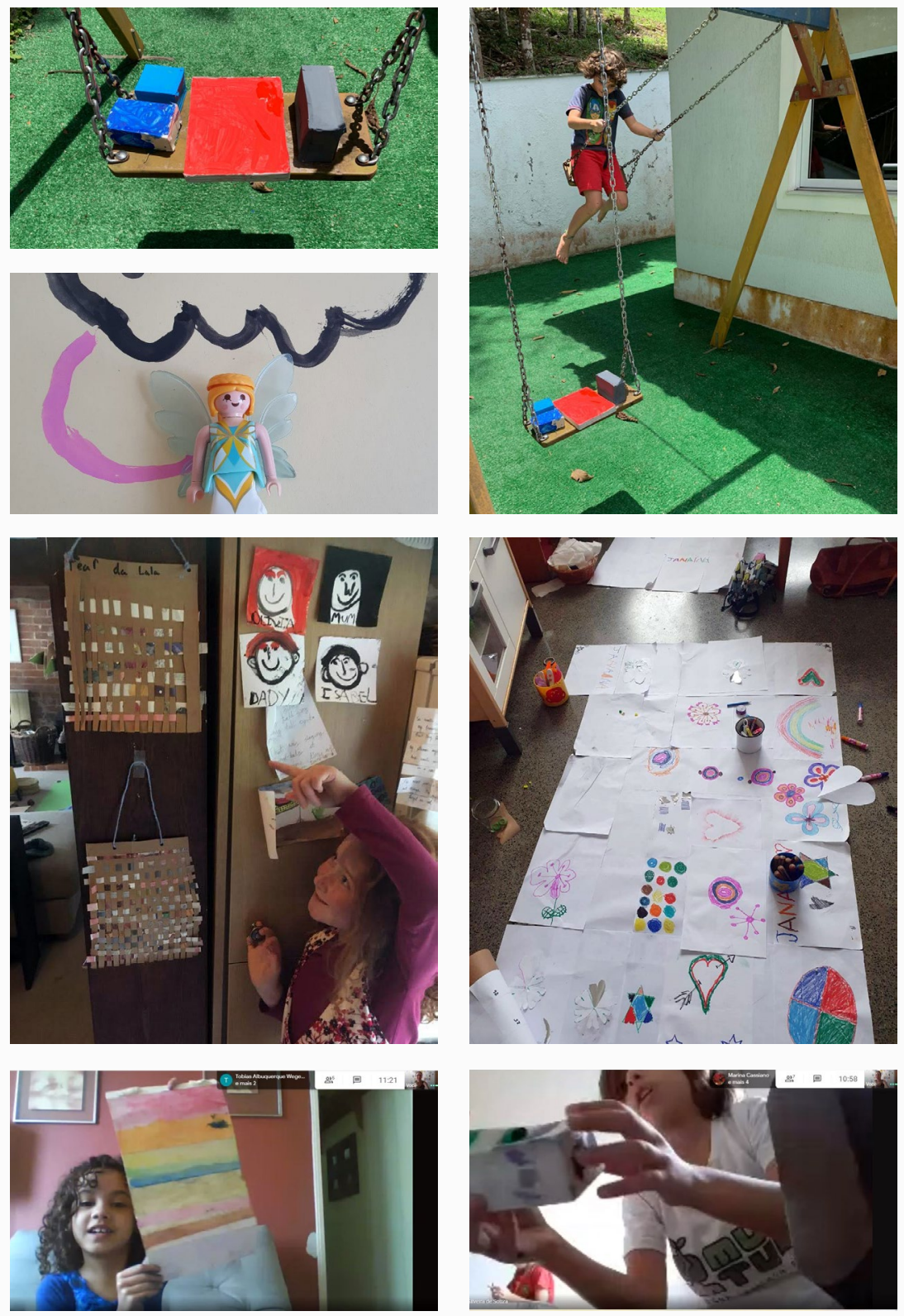

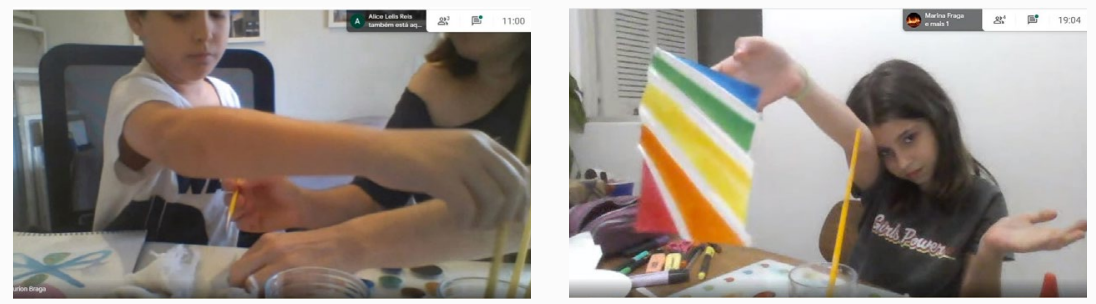

Colagem, pintua e construção... online!
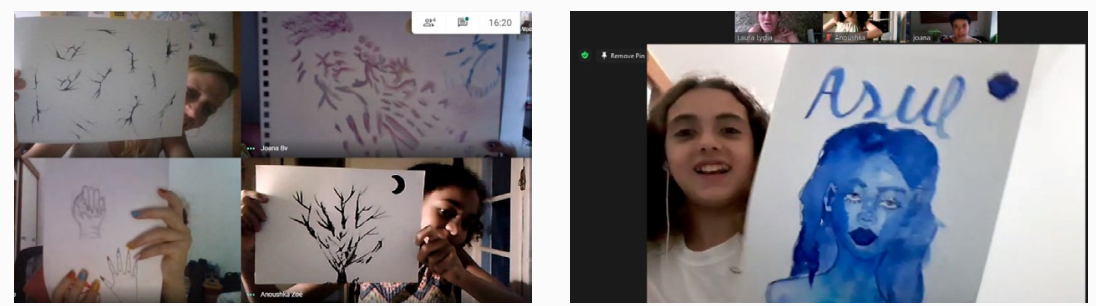

Desenhar jutnos. 

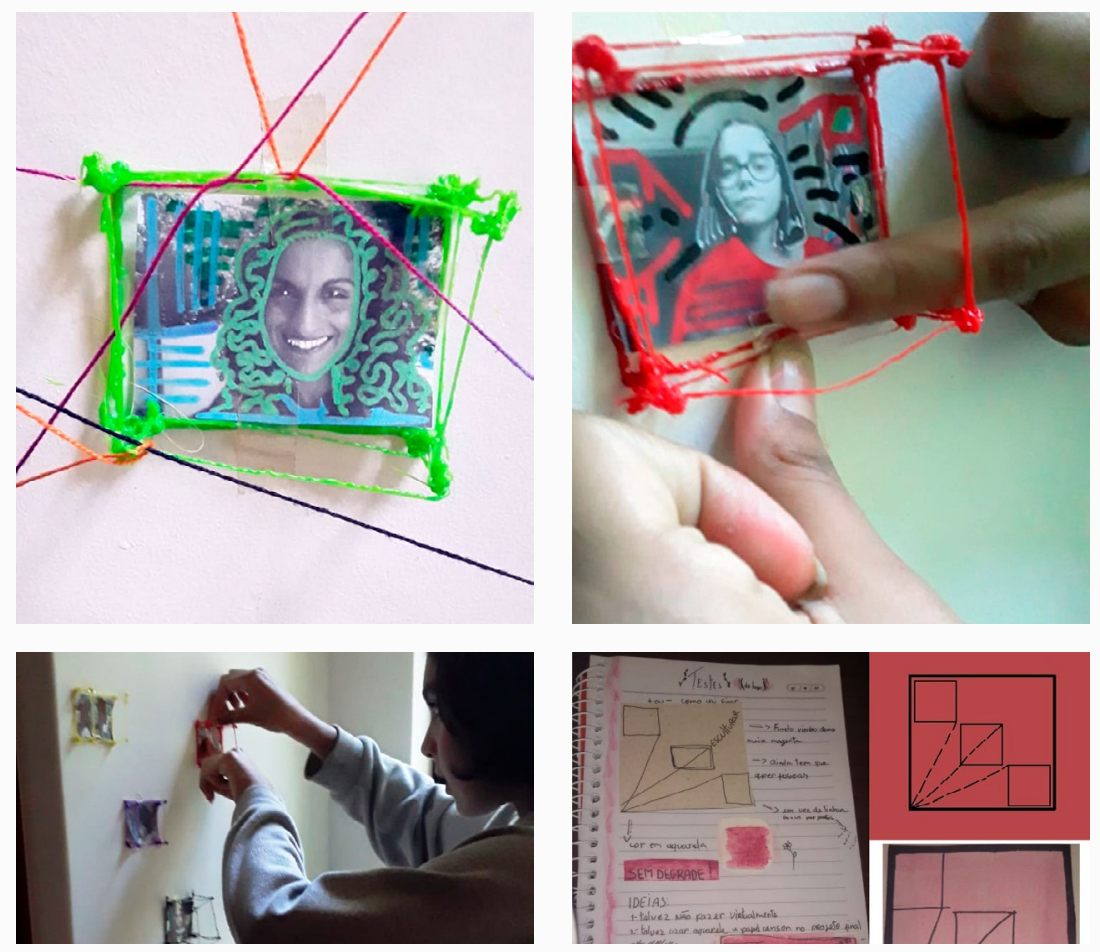

Alguns trabalhos finais. 


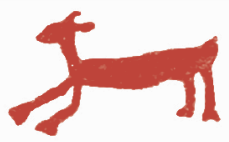


REPENSAR AS EXPERIÊNCIAS ARTÍSTICAS FACE AOS DESAFIOS DA DECOLONIALIDADE 
ty 


\section{Ethel Batres}

\section{LA PARTITURA ES LA \\ IRREALIDAD DE LA MÚSICA, \\ ASÍ COMO LAS POLÍTICAS \\ PÚBLICAS SON LA FICCIÓN \\ DE LA EDUCACIÓN ${ }^{1}$}

\section{RESUMEN}

Reflexión sobre la colonización de la escucha y su repercusión en América Latina. Ubica la trilogía: academia-artista-docente, como referente para contrarrestar a un estado y grupos de élite que desde una colonialidad intencional pudieran buscar la captura de la decisión política de presentes y futuras generaciones. Considera los planes de formación de maestros como obras de arte mayor en la perpetuación de la colonialidad. Cierra con una metáfora que invita al lector a tomar acciones.

Palabras-clave: Educación - música - colonialidad - acción

\section{RESUMO}

Reflexão sobre a colonização da escuta e sua repercussão na América Latina. Localize a trilogia: academia-artista-professor, como uma referência para neutralizar um estado e grupos de elite que, a partir de uma colonialidade intencional, poderiam buscar capturar a decisão política das gerações presentes e futuras. Considere os planos de formação de professores como grandes obras de arte para perpetuar a colonialidade. Feche com uma metáfora que convida o leitor a agir.

Palavras chave: Educação - música - colonialidade - ação

\section{ABSTRACT}

Reflection on the colonization of listening and its repercussion in Latin America. Locate the trilogy: academia-artist-teacher, as a reference to counteract a state and elite groups that from an intentional coloniality could seek to capture the political decision of present and future generations. Consider teacher training plans as major works of art in perpetuating coloniality. Close with a metaphor that invites the reader to take action. Keywords: Education - music - coloniality - action

\footnotetext{
${ }^{1}$ Resumen de la ponencia brindada en el Congreso de Enseñanza-aprendizaje de las artes en América Latina: Colonialismo y cuestiones de género. 25 de abril de 2019, São Paulo, Brasil.
} 


\section{DE LA COLONIZACIÓN DE LA ESCUCHA Y ALGO SOBRE LA MÚSICA Y LA CULTURA DE MASAS}

Sin duda, el colonialismo musical se había iniciado mucho tiempo atrás. Fue cuando los atabales, tunes, sonajas, burundangas, xules, tzijolajes, quijongos, caracoles, ocarinas, vasijas silbato y muchísimos objetos sonoros más, fueron proscritos o quedaron relegados a la categoría de "tonterías", "juguetes", "bulla", "barulho" o en el peor de los casos: "sonidos del demonio", con lo que aparentemente quedaron condenados al silencio, no sólo desde el punto de vista organológico, sino también desde su contexto de producción sonora: la celebración, el rito, la socialización, la curación, la religión y en consecuencia, de la dignidad de poder de representatividad que el sonido, la voz y la música otorgan a quien los posee o escucha.

Por ello, en el proceso de colonización, los pueblos originarios, debieron abandonar la escritura ideográfica y jeroglífica para aprender el alfabeto latino, debieron dejar de lado la narrativa oral, que jamás llegó a ser considerada como literatura y debieron abandonar su expresividad sonora, para transformarla en "música", bajo el canon centroeuropeo. 400 años después, con partituras rotando por el Nuevo Mundo, con coros y bandas sonando en las iglesias y plazas de las ciudades, y ya con muchas academias y conservatorios fundados, la música europea, su sistema de notación y aprendizaje, imperaba en el campo llamado "culto", servía de modelo y paradigma de exquisitez y refinamiento, acompañaba el poderío económico, militar y político de los criollos, y legitimaba un imaginario social latinoamericano que dejaba confinadas (aunque nunca "silenciadas") al terreno de lo vulgar o del servicio doméstico a gran cantidad de músicas tradicionales y populares.

A finales del siglo XIX el avance en el fenómeno de la grabación sonora iba de la mano con una industria naciente. A partir de 1899, la compañía Gramophon, de Londres, empezó a enviar a sus ingenieros de sonido a realizar trabajo de campo a numerosas regiones del orbe. América Latina no fue la excepción. Al inicio, se mezclaban un poco los propósitos. La incipiente etnografía musical compartía espacio con las productoras emergentes y surgió en medio de una concepción colonial del mundo y en una América Latina colonizada y bien dispuesta a recibir lo que de sus colonizadores llegara.

Los pioneros etnomusicólogos-técnicos, llegaban a las localidades e instalados en algún hotel, provistos de equipos portátiles, colocaban un aviso en el diario ofreciendo grabar a los músicos locales. Para los músicos (y esto se mantiene en la actualidad), esto se consideraba un honor, un privilegio. Permitía el desarrollo de un nuevo invento, actualizaba en el uso de la tecnología del momento y estimulaba el ego. Estos investigadores, mezcla de etnomusicólogos con ingenieros de sonido, al recabar suficiente material, regresaban a su sede (que podía ser Londres, París o Berlín) en donde se procedía a seleccionar el material, bajo criterios que posteriormente se identificaron como "comercializables" $y$, ulteriormente, se integraba 
a producciones de las cuales se hacían copias que regresaban a la localidad donde habían sido grabadas para ser vendidas entre "los nativos". Es decir, al inicio de estos procesos, la tecnología de sonido no produjo una "desterritorialización" de la música, como posteriormente se dio. Era únicamente la industria cultural extractivista y la aparición del "nicho de mercado" (en aquel momento no llamado así) exótico para unos, y "propio" o identitario, para los otros.

La industria de aquel momento estaba enfocada en los aparatos, más que en la música grabada. De esa cuenta, la música "era de todos, estaba allí para ser grabada" solo había que recogerla, reproducirla y venderla. Ya en 1909, el sello Víctor, empezó a pagar a los músicos por sus grabaciones, es decir, por la interpretación musical, pero no regalías sobre las ventas, ni derechos autorales.

En esta etapa inicial, hubo distintas maneras para grabar en América Latina: a) Los "recording trips" o "viajes de grabación" de las compañías europeas; b) pequeñas compañías locales que empezaban con el montaje de estudios de grabación; c) usuarios independientes que adquirían equipos); d) viajes de músicos buscando ser difundidos.

Para el caso de Guatemala, se comenta que en el año 1915, se realizó la Exposición Internacional Panamá-Pacífico en la ciudad de San Francisco, California. Al evento fue invitado el grupo marimbístico de los Hermanos Hurtado, de Quetzaltenango, Guatemala. Allí, en un incipiente estudio de grabación se realizaron los primeros discos con melodías de marimba guatemalteca. (Figueroa: 9)

El Cuarto Centenario de la colonización de América Latina, constituyó el inicio del colonialismo sonoro y de sus formas de escucha asociadas. Comento algunas referencias de Juan Pablo González (2018): la llegada de aparatos auditivos, sonoros y musicales, generó nuevas formas de escucha, con algunas consecuencias:

1. Los músicos se escucharon a sí mismos, por primera vez. Lo que implicó también la posibilidad de emitir juicio sobre ellos mismos.

2. Pudieron acercarse a un repertorio grabado por otros ( $\dot{c}$ "disecado", congelado, "re-tocado", mostrado?), que pudo convertirse en objeto de estudio, crítica, modelo o comparación. Antes de poder capturar el sonido, el fenómeno del concierto en vivo permitía un tipo de aproximación limitado por la posibilidad de acceso a la presentación, y por la capacidad memorística para recordar elementos significativos de la misma, tanto desde los aspectos técnico-musicales, como desde el repertorio y la representación asociada.

3. El contacto con repertorio externo, generalmente acompañado de una propaganda que legitimaba la excelencia de los intérpretes a partir de su procedencia, podía producir una doble externalidad interpretativa que imponía un canon. Esto, al ser referido desde un núcleo de poder, en cierto modo paralizó al subordinado, al obligarlo a escuchar o a reproducir un repertorio de una manera exacta, en contraposición a la lectura desde la partitura, que generaba una propia performatividad, o el buscar reproducir desde la 
memoria ("al oído"), procesos que implicaban una apropiación e hibridación más dinámicos.

4. Se incrementó en general la conciencia pública de la escucha, y se generaron los primeros elementos, aún endebles para el estudio de la música grabada.

Hacia 1920, la amplia difusión de los aparatos reproductores de música entre los habitantes de poblaciones urbanas y rurales dio un giro a la manera de escuchar. El fonógrafo y el gramófono no necesitaban electricidad y tuvieron amplia difusión. El famoso etnomusicólogo argentino, Carlos Vega, tenía la sospecha de que alguna música recolectada por él y su colega Isabel Aretz, pudieron llegar a oídos de su audiencia por medio de grabaciones y no por intérpretes originales.

Aún con esto, aquella música grabada, constituyó una zona de retorno de lo propio a sí mismos. Esos artistas son referentes importantes y nos remiten a observar varias posibilidades. "Escúchate", pudiera ser la voz del colonizador al subordinado, desde una esfera "civilizadora", "difusora", "de rescate", o bien, comercial, institucional, "pedagógica", pero en todo momento colonial.

La mediatización de la performatividad es uno de los gestos más violentos de representación del Otro por los poderes coloniales. Esto va desde la construcción de la "imagen visual" (el traje -transformado muchas en "vestuario de representación”, los elementos complementarios, la disposición escénica, el paso de baile, el gesto, la postura, entre otros), pasando por la "imagen auditiva" (nuevos rasgos armónicos, melódicos, instrumentales, formas de emisión sonora, inclusión de otras modalidades técnico-interpretativas, etc.) hasta conformar una "imagen artística" muchas veces descontextualizada (extraída del momento del ritual, de la plegaria, de la fiesta, para convertirla en elemento de la "función", "el concierto", "el espectáculo"). Esto se dio en muchos conjuntos que conformaron la imagen, generalmente idealizada, mezclada y avalada oficialmente, como "típica", "folklórica" o "turística" en un país. La musicología llegó tarde a los estudios culturales. Le costó marcar el paso y alcanzar a las industrias culturales que con la bandera de la música popular por delante, inundaban la vida social, cultural y económica de las ciudades, no sin un margen de ganancias considerables. El rígido campo de acción musicológico, la hacía dividirse en dos grandes áreas: la música de tradición escrita -llamada "clásica", académica, docta o culta y la música de tradición oral -llamada tradicional o folklórica. La gran ausente fue siempre la música popular.

Pioneros de la musicología y etnomusicología latinoamericana iniciaron el trayecto con la documentación y recopilación de archivos sonoros, conscientes de un caudal amplio y no clasificado, el cual organizaban con respetuoso cuidado, mezcla de dedicación y asombro, aunque no necesariamente aún mediado por una reflexión decolonial. Finalmente, desde otros campos llega la reflexión a la música, y se empieza a analizar desde la propia región, y no bajo la mediación de otros. A partir de documentaciones y reflexiones sobre la diversidad, el surgimiento de la 
conciencia de ser "otros" respecto de Europa, y "otros", "varios", "diversos" dentro de nosotros mismos, va consolidándose paso a paso una conciencia que busca el distanciamiento de la colonialidad/modernidad eurocéntrica, pero que va tomando distintos matices según el tiempo. Se ha cedido el paso de la oposición civilización/ barbarie, a la posición "folklórica", "folklorizante", o "de proyección folklórica" en la cual se continúa un patrón de poder, pero en este caso, interno.

La perspectiva eurocéntrica se naturaliza y generalmente no se cuestiona. Por lo mismo, la conciencia poscolonial va constituyéndose y aceptándose poco a poco, hasta que logra atreverse a cuestionar, estudiar, dialogar, proponer o gritar. Esta relación implica interrogar y demandar al Primer Mundo, desde el Tercer Mundo, pero desde la perspectiva de la propia enunciación. Básicamente, considero que tres voces han aportado o deben entrelazarse en esta construcción. Por una parte, la Academia, desde los núcleos de investigación, reflexión y debate. Por otra, la producción del artista. Y por otra, la perspectiva surgida desde los educadores.

En 2017, en el contexto del prestigioso escenario cultural europeo Documenta 14, el compositor guatemalteco Joaquín Orellana presentó su obra: Sinfonía desde el Tercer Mundo. La obra constituyó un gigantesco planteamiento estético desde, pory a partir de América Latina.

La obra estableció un parangón musical deconstructor por varias razones. El nombre ya es simbólico; inmediatamente genera una asociación contrapuesta a la Sinfonía del Nuevo Mundo, de Antonin Dvorak, quien presenta la apreciación de un turista feliz que visita a otro país, en tanto Orellana compone a partir de una realidad lacerante, desconcertante en la que mezcla los sonidos, voces y cantos que reflejan una realidad quasi caótica que ha vivido en carne propia: la de nacer en Guatemala. La obra, aún con el nombre europeo de "Sinfonía", es un reto a la deconstrucción, porque ni formal ni estructuralmente responde al género. La obra incluye orquesta sinfónica, coro de adultos, coro de niños, utilería sonora basada en las teclas de la marimba de Guatemala, la propia marimba guatemalteca y declamador. Todo conjugado dentro de una urdimbre sonora contemporánea, que entrelaza elementos de fuerte preocupación social en medio de referentes históricos para la Guatemala que vivió la guerra, como la inclusión de los lamentos que realiza el coro, en relación con las masacres de indígenas mayas en la comunidad de Río Negro en los años 80. Decolonizadora, retadora y disruptiva es la obra que nos sirve para ilustrar esta postura crítica del compositor.

Las implicaciones nos remiten a pensar que si hay una crítica poscolonial, debería haber también (y la hay) una creación artística poscolonial y ambas deberían estar coordinadas con una pedagogía poscolonial. Por lo mismo, si hubo y existe una colonización de la escucha, unida a mecanismos de transmisión sonora y musical a la cultura de masas para la pervivencia patrones y de mercancías redituables, será necesaria una educación del sentido crítico que permita una creación artística y una escucha poscolonial que favorezca caminar hacia un eje descolonizador. 


\section{DE LA COLONIZACIÓN DESDE EL ESTADO, LAS POLÍTICAS EDUCATIVAS Y CULTURALES}

"La perspectiva eurocéntrica no pertenece exclusivamente a los europeos o a las fuerzas dominantes del capitalismo mundial, sino a quienes han sido educados bajo su hegemonía.". Quijano (2000:343)

Testimonio preliminar:

"Iniciaba mis estudios para Maestra de Educación Musical. Repasaba con emoción los temas que abordaríamos en el curso de Seminario: una revisión de la Metodología de la Educación Musical: Orff, Dalcroze, Kodally, Martenot, Suzuki, Willems... y yo, sin conocerlos, ya creía en ellos, incuestionablemente. Es más, que vinieran de Europa y otros países les daba una especie de "sello de garantía"... Mi aprendizaje musical inicial ya me tenía preparada (colonizada) para esto. Luego, como docente participé del desfile de "modas pedagógicas" que fueron aplicándose: la reingeniería, el ISO:9000, el Constructivismo, las "Competencias", el Couching, el "Mindfulness" y en medio de ese caos, los educadores musicales empezamos a desaparecer..."

¿Qué comentarios nos merece el entramado anterior?

Inferimos que las políticas educativas no fueron fenómenos tardíos en el contexto colonial.

Los sistemas educativos iniciaron tempranamente en Nuestra América. Y poco a poco, mientras la maquinaria colonial se enraizaba, se importaban ideas, maestros, textos, sistemas y materiales. Refundamos la escuela sobre las bases que nos trajeron, estudiamos los postulados que fueron trasplantados, repetimos los nombres, datos y fechas de los libros que importamos, y cuando comenzamos a escribirlos, únicamente adaptamos datos básicos de geografía y algunos nombres locales. El montaje colonial no rebasó la concepción implícita en los textos, ni en los materiales, ni en los métodos, ni en la infraestructura, ni en la estructura sistémica, ni en el idioma de transmisión porque no cuestionábamos el esquema, porque no dudábamos del mismo, porque no se había creado conciencia de ello. Al contrario, estábamos en favor del mismo, que era "estar al día, actualizados". Contribuíamos hasta con orgullo a reproducir el esquema previamente fijado. Pero todo tiene un límite.

Violeta de Gainza, pedagoga musical, comenta: "Mientras algunos colegas míos escogían dedicarse a analizar el modelo pedagógico monopolizador (curricular)... yo intentaba como podía y desde donde podía, comprender las causas del estado crítico, conturbado, que se vivía”. (Gainza:2007)

Desde distintas procedencias, una conciencia venía forjándose. Hablaron Frei- 
re, Mariátegui, Vasconcelos. Muchos más. Desde la educación musical lo dijo Aharonián: "Los hijos de los que ejercen el poder son enseñados para ejercerlo mañana, fuera de los planes de enseñanza." (2000:10)

\section{COMENTARIOS A ALGUNOS PROCESOS COLONIALES MODERNOS TANTO EN LAS POLÍTICAS CULTURALES COMO EDUCATIVAS:}

\section{LAS POLÍTICAS CULTURALES Y EDUCATIVAS EVIDENCIAN COLONIALIDAD INTENCIONAL}

A nivel institucional, Guatemala desarrolla políticas de aparente "corrección" y de buena relación con los países vecinos (sobre todo el más grande, "del Norte"), para dar continuidad y mantenimiento a los préstamos y donaciones que nos brindan, condicionándonos con perderlas ante la más mínima manifestación de cuestionamiento. (Cuestionamiento que, por demás, tampoco se realiza).

Después de la segunda guerra mundial, la condición de triunfador de los Estados Unidos, generó que sin enfado estructurara elementos para incidir en las políticas educativas de casi todos los países de América Latina. Conocida es la Conferencia Internacional de Bretton Woods, New Hampshire, Estados Unidos, (1944), que fijó el orden monetario, así como la realización del Consenso de Washington (1989), del cual emana la propuesta del economista John Williamson, con un paquete de reformas «estándar» que incluía 10 fórmulas para los países en desarrollo azotados por la crisis. En la misma se contempló la reordenación de las prioridades del gasto público. Tal tarea se llevaría a cabo con el recorte del gasto público sin recurrir a los impuestos. Los subsidios de la administración pública, sobre todo los referidos a instituciones culturales serían los primeros en ser reducidos. La eliminación paulatina de las subvenciones permitiría asignar esos recursos en áreas estratégicas de carácter social. Sin embargo, la salud y la educación no fueron beneficiadas. Al contrario, las subvenciones fueron minimizadas y una fuerte tendencia privatizadora se suscitó. El neoliberalismo se instauró y la educación recibió el embate. Dentro de la misma, las artes fueron punto vulnerable que recibió la presión. Por ello, la medida administrativa fue ahorrar recursos: suprimirlas, fusionarlas o minimizarlas. La decisión no venía desde la pedagogía y su reflexión, no venía desde el análisis sobre posibilidades de integración, de interdisciplinariedad o similares. La decisión venía desde la economía.

30 años después, las secuelas son evidentes. Ha habido medidas paliativas, ensayos de "reacomodo", pero no todas han sido felices o sabias. Y ahora, se ha unido otro actor al elenco. Un agente paralelo, muy interesado en intervenir en las políticas públicas: las élites económicas y financieras de los países. Cito a continuación algunos párrafos del trabajo de Ana Castellani (2019) en torno a este tema: 
"En las últimas décadas las élites económicas latinoamericanas han demostrado un creciente interés por incidir en la orientación de las políticas educativas mediante diversos mecanismos. El interés (...) se inscribe en un proceso de mayor alcance que actualmente pone en cuestión la calidad de las democracias en la región: la captura de la decisión política."

Según Castellani, tres motivos tienen las élites para interesarse por la educación:

a) La necesidad de moldear la formación de "los recursos bumanos del futuro" en función de las demandas del sector productivo.

Comentario: No en función del ser humano, de su desarrollo pleno, de los fines de la educación del país, de la Constitución Nacional, etc. Se trata de producir obreros alfabetizados, capaces de leer los manuales de instrucciones, para tener un mejor desempeño laboral, que continúe beneficiando prioritariamente a la empresarialidad.

b) La posibilidad de ampliar y acceder fácilmente a un mercado que ofrece rentables oportunidades de negocios brindando diversos servicios educativos donde el Estado es el principal demandante, regulador e inversor (capacitación docente, plataformas educativas, información de datos, edición de materiales, realización de evaluaciones estandarizadas, etc.)

Comentario: Bajo la apariencia de "interés sano" obtienen financiamiento para realizar proyectos en los que ponen oferta de sus bienes y servicios, los cuales generalmente obtienen por medio de contratos con el Estado.

c) La pretensión de difundir ideas, valores, actitudes y predisposiciones propias del ámbito empresarial como si fueran cosmovisiones del conjunto social que le permiten legitimar socialmente cambios en las políticas públicas que babiliten y/amplien el proceso de mercantilización educativa.

Comentario: Se realiza un trabajo de "siembra ideológica" la cual cuidan y abonan constantemente (y en algunos casos, ya empieza a rendir frutos). Paradójicamente, no parece haber otro tipo de semilla sembrada en paralelo. ¿Hay trigo y cizaña juntas?

En cada país las élites se organizan en agrupaciones similares que tienen distintos nombres pero provienen del mismo segmento socioeconómico de poder. Hace una década constituyeron el grupo latinoamericano denominado REDUCA. Castellani, cita a Santos, A.V y Guimarães, quienes comentan de la siguiente manera:

"Estas organizaciones son financiadas por grandes empresas interesadas en que sus iniciativas en materia educativa se presenten como si fueran plurales y se validen mediante diagnósticos de expertos "desinteresados". De esta forma se pretende ir desdibujando progresivamente la distinción entre derechos sociales e individuales 
para avanzar en la idea de la educación como bien/servicio de mercado.”

Comentario: Empresarios vinculados con el gobierno forman parte de este grupo, que se manifiesta con incidencia fuerte en el sistema y que tiene un rostro grato para los docentes: la erogación del Premio "Maestro 100 puntos" o su equivalente en cada país. Este nexo con los maestros permite mostrar una "mano amiga", que valora su trabajo y que estimula a estar al día, a ser innovadores y a plantear proyectos prácticos de cambio. De manera interesante, sigue siendo un concurso, estimula la competencia, premia trabajos de aula, pero no necesariamente fomenta la investigación, los trabajos de análisis, o la crítica, entre otros.

\section{¿SE TRAZAN POLÍTICAS DECOLONIALES DESDE LOS MINISTERIOS DE EDUCACIÓN O DE CULTURA?}

Realmente parece difícil. Porque las acciones están muchas veces inmersas en políticas, convenios y acuerdos internacionales que luego los países se ven obligados a cumplir. Otras, en función de presiones internas, y pocas veces, por iniciativas de grupos artísticos, de colectivos sociales que requieren y demandan a la clase gobernante mejoras dentro de sus sistemas.

Algunos ejemplos (desde Guatemala):

Aun cuando la bandera del "multi e interculturalismo" ingresó al discurso oficial, hace unos 40 años, los resultados en la práctica se dan dentro de marcos limitados, en entidades creadas para el efecto hace décadas, pero no actualizadas en su proyección ideológica, sino más bien dirigidas (colonizadamente) desde perspectivas de rendimiento empresarial (más que beneficiar a los propios pueblos o al sector de las culturas, favorecen al sector del turismo). El Ministerio de Cultura y Deportes refrenda y sostiene a grupos artísticos que representan el "canon" europeizante. También a los grupos que portan oficialmente la representación artística de Guatemala. Los mismos, en su mayoría, se ubican en una etapa de "nacionalismo homogeneizador" con matiz "folklórico", que refuerza un imaginario incuestionado. La organización de estos grupos, la procedencia étnica de los artistas y el enfoque desde el que generan su actividad performática, sigue dándose en la relación de supremacía del mestizo-ladino, sobre los otros grupos etno-culturales, en un país en donde la presencia maya es contundente.

Los planteamientos anteriores no van a extremos, ni sugieren la supresión o anulación de las diversas agrupaciones artísticas indirectamente referidas; de ninguna manera. Hablamos de la posibilidad de una reflexión seria en las diversas direcciones, jefaturas y administraciones culturales. También de una revisión en los procesos formativos de los artistas, con miras a la generación de mayor conciencia en estos temas. Esto, con la finalidad de abrir un debate en torno a la pertinencia cultural y contemporánea de los mismos, la cual implique, con el tiempo y varios 
procesos, algunas modificaciones. Por lo anterior, sugerimos la posibilidad de permitir que las voces no presentes, tomen el lugar debido y que otros dejen de hablar por ellos, con un discurso por demás falaz, aunque pueda ser deslumbrante y hermosamente colonial.

El Ministerio de Educación tampoco queda inmune ante esta situación y contribuye a difundir los preceptos que inconscientemente remarcan ejes de colonialidad y no transforman el panorama. Tras una guerra interna de 36 años, Guatemala firmó los Acuerdos de Paz que obligaron a una Reforma Educativa. Pero la misma mantiene un discurso a tono con las propuestas cambiantes dentro de las distintas modas pedagógicas que surgen desde los centros de poder. La inteligenzzia local no cuestiona ni propone cambios drásticos en el enfoque de la política. En términos generales, da continuidad a procesos que han recibido, o modifican aspectos superficiales pero no de fondo. En algunos momentos se ha rumorado que el Ministro de Educación se nombra, luego de que su perfil pasa la debida revisión y autorización por parte de la AID -Agencia Internacional para el Desarrollo, dependencia de la Embajada de Estados Unidos en Guatemala. Este es un dato no comprobado, únicamente es vox populi.

La "ola de Reformas" realizadas en muchos países de América Latina entre los años 90 y 2000 está en procesos de revisión. La Reforma Educativa en Guatemala ha sufrido varias adecuaciones a lo largo de 20 años; éstas, no son de fondo, solo de forma. Las evidencias no muestran referentes de una transformación decolonizadora. En cuanto a las artes dentro de la misma, diremos que en general, fueron progresivamente invisibilizadas a lo largo de dos décadas. De una época anterior, aún en medio del conflicto armado, se tenía una entidad encargada del arte escolar (la Dirección General de Educación Estética). Posteriormente se pasó a un período acéfalo, y luego a la constitución de un Departamento de Educación Artística, que depende de una instancia mayor, relacionada con la Calidad Educativa. El departamento es pequeño, trabajan con constancia, pero no ejercen presión en la línea decolonial. Realizan varias actividades con eficiencia. Aunque desde la perspectiva decolonial, sus acciones no son críticas ni deconstructoras, sino reforzadoras y promotoras del orden establecido, por cuanto no cuestionan las políticas que puedan ser lesivas y las acatan dócilmente.

\section{MUCHOS DISEÑOS CURRICULARES NO INCLUYEN UNA PERSPECTIVA DECOLONIAL}

En general, el paradigma de diseño curricular que se maneja en Guatemala, tanto en el Ministerio de Cultura como en el de Educación, es monopólico, hegemónico e impositivo. Aunque convoca a docentes como representantes en diversas revisiones, responde a líneas de acción previamente definidas desde las autoridades mayores o reservando el derecho de decisión final a las jefaturas, viceministerios o 
ministro. Esto invisibiliza las voces de los docentes y otros actores en la construcción; en consecuencia no es bien recibido por la comunidad educativa en general, ni incide en cambios radicales. (Salvo uno evidente: La progresiva disminución de las artes dentro del sistema escolar).

Dentro de un modelo restrictivo, poco puede hacerse para escapar del esquema, aunque el discurso enuncie algo diferente. Violeta de Gainza plantea una posibilidad alterna y no colonial dentro de su propuesta pedagógica. Su postura conceptualizada durante toda una vida de docencia y reflexión, se ha trasladado y difundido de manera "paralela", pero extra-sistema, desde la entidad de la que ella es co-fundadora: El Foro Latinoamericano de Educación Musical - FLADEM, con el que han planteado batallas descolonizadoras desde lo ideológico, metodológico y filosófico buscando incidencia en la lucha por el rescate de las artes, y particularmente la música en la escuela. El FLADEM ha discurrido por varios senderos: la formación de educadores musicales, la realización de cursos, seminarios, encuentros y congresos nacionales, regionales e internacionales. También la publicación de documentos, textos y libros sobre temas docentes diversos. Con reflexión decolonial ha sido pionero en la difusión del pensamiento pedagógico musical latinoamericano.

Según la intensidad de la política interna de cada país, para minimizar, eliminar, fusionar o invisibilizar la educación musical y las artes por extensión, el FLADEM ha mantenido posturas de defensa que han variado: el envío oficial de comunicaciones a autoridades de distintos países, así como a Rectores Universitarios, jefes de entidades incidentes, etc. La organización de debates públicos en instancias oficiales y entrevistas sobre el tema en diversos medios. Ha participado en marchas, manifestaciones, conciertos, campañas y otras acciones, luchando por no perder espacios, tiempos y horarios curriculares que, en varios países, son territorios epistemológicos con tendencia a desaparecer.

Las artes pasaron de ocupar un horario y ser brindadas por un especialista dentro del currículo, a ser una materia "integrada", sin un especialista a su cargo, o con un especialista que repentinamente se vio obligado a trabajar lenguajes artísticos que no manejaba. Esto se ha podido observar de manera generalizada, y el FLADEM lo ha manifestado de diversas maneras. Esa lucha, para las autoridades ha podido representar transgresión, incomodidad y malestar. Pero ha sido necesaria. El no hacerlo significaba el silenciamiento, la aceptación acrítica de las acciones y la pérdida de la congruencia con el ideario que nos ha movido durante muchos años.

\section{LOS PLANES Y PROGRAMAS DE ESTUDIO TIENDEN A PERPETUAR EL COLONIALISMO}

Edelberto Torres-Rivas, eminente sociólogo de Guatemala, difunde en el estudio "Guatemala un edificio de cinco pisos", una tesis sobre la distribución desigualitaria de oportunidades y la estratificación social. Realiza allí una metáfora social, que 
tristemente expresa en uno de sus enunciados: El edificio no tiene elevadores. Y esto es así. La estructura está armada para no ceder espacios. Aharonián (2000) lo ha planteado: "La sociedad de mercado es enemiga de los hombres libres".

Es evidente que nuestro sistema educativo está destinado a formar obreros alfabetizados y a perpetuar la mano de obra barata. Es el perfil que subyace revestido de una capa de actualidad, bajo un discurso lleno de lugares comunes y expresado con la autoridad que el oficialismo otorga y la colonialidad refuerza. La lectura de los fines de la educación y de las descripciones en las publicaciones de los departamentos curriculares oficiales refleja trabajos de muchas horas de atención. Sin embargo, no necesariamente ese intenso trabajo es crítico de la realidad. Los resultados que se obtienen, distan enormemente de lo propuesto.

\section{LOS MATERIALES EDUCATIVOS DAN CONTINUIDAD A ELEMENTOS DE LA COLONIALIDAD}

Un caso paradigmático como referencia.

Durante 5 años consecutivos, estudiantes universitarios de Guatemala y el resto de países de Centroamérica fueron "beneficiados" aparentemente por el programa RTAC-II (1986-1991) para América Central. El programa literalmente fue presentado para:

"Proporcionar libros de texto y materiales técnicos actualizados, de origen estadounidense y en español, primariamente a estudiantes universitarios de los primeros tres años, en América Central (Panamá, Honduras, El Salvador, Guatemala y Costa Rica). El proyecto estará conducido por AID (Agency for International Development) - cuya misión es fortalecer la seguridad de los Estados Unidos y el mundo libre al asistir a otros países en su desarrollo económico, institucional y de desarrollo social."

En otra parte del documento dice: "El uso de los libros de texto norteamericanos... se encuentra en peligro de regresar a las notas de clase, fomentándose la piratería de los impresos norteamericanos". "El principal objetivo de RTAC II es político: aumentar el acceso, presencia e influencia en la región centroamericana de Estados Unidos al aumentar la participación e influencia de este país en la educación superior y el entrenamiento de profesionales y líderes centroamericanos". ${ }^{2}$

Benjamin Curtis dice: "No podemos llenar el vacío de libros en el tercer mundo, únicamente con libros"'. De ahí que urge ordenar e impulsar definitivamente el mundo del libro centroamericano. Por esto, es más fácil recibir libros y materiales

\footnotetext{
${ }^{2}$ Citado literalmente por Irene Piedra Santa en el documento: El proyecto RTAC-II (1986-1991) para la América Central. Un comentario crítico. (Ver referencias bibliográficas). p. 6-7

${ }^{3}$ Citado por Irene Piedra Santa en el documento referido.
} 
obsequiados que hacerlos. Y más fácil conseguir préstamos para comprar libros de un catálogo ya elaborado, que crearlos. Y más sencillo escribir libros según "una guía" predeterminada por un consultor, que dejar en libertad de creación a un autor. Y mucho más complejo generar en alguien qué y cómo escribir, que entrenar a alguien sobre cómo elegir entre propuestas creadas las que puedan ser más pertinentes para alcanzar fines trazados (generalmente por otros).

Los libros son armas, de resguardo, en cualquier sentido en el que se vean.

La palabra sigue siendo constructora. Por eso hay que atesorarla y dejar que fluya en todos, en todas.

\section{LA FORMACIÓN DE MAESTROS ES LA OBRA DE ARTE MAYOR EN LA PERPETUACIÓN DEL COLONIALISMO}

La formación de los maestros incide en toda transformación. Por lo mismo, desde los centros de poder, la atención a los mismos es muy alta. Disponer de ellos, como si fueran posesiones es una garantía de transmisión de elementos hacia generaciones completas de ciudadanos que se están formando.

La figura del maestro, otrora magnificada por las gestas revolucionarias ha perdido en gran medida el respeto y el sentido que tenía. En la actualidad, muchas veces bajo la égida de líderes sindicales, recibe la reacción desfavorable de una ciudadanía cansada de discursos falaces y resentida por el abandono de las aulas y el incumplimiento de deberes hacia muchos niños y jóvenes.

Pero esto no es gratuito. La formación de maestros en general ha sido descuidada. Las asignaciones presupuestarias institucionales se minimizan. Las universidades, normales o centros formativos suelen ser espacios débiles, con poca visión y expectativa de los hechos formativos que allí ocurren. Pero independientemente de ello, hay fuerte tendencia a implementar en ellos "modas pedagógicas", que generalmente vienen emanadas desde núcleos de poder, con imposición de ideas y que tienen como meta trasladar una forma de pensar, sentir y actuar congruente con la legitimización de las propuestas.

Ese accionar va incorporándose profundamente en la conciencia del joven docente, de manera que no permite el estímulo del cuestionamiento ni la criticidad. La práctica docente no es un espacio realmente experimental, sino más bien, el cumplimiento burocrático de cierta cantidad de horas de clase, complementadas con innumerables formularios y datos para llenar, los cuales van preparando al nuevo maestro para ser un excelente burócrata.

Como el maestro no ha sido formado creativamente, depende en extremo del Currículo Nacional, de la Guía de trabajo, de las Orientaciones docentes o referentes equivalentes. Se aproxima a ellos tomándolos como una muleta, y los curriculistas se esfuerzan por convertirlo en un experto en cuanto al manejo de documentos que no son infalibles, que se modificarán constantemente (o al menos 
eso se esperaría) y que no son cuestionados en realidad. En verdad, la formación del maestro debería prepararlo para movilizarse autónomamente y promover, a su vez, una educación para la autonomía, al mejor estilo Freireano. La metodología, recursos y evaluación son los obligados. Pocas variantes entre unos y otros. Poca innovación real y mucha a nivel superficial. Abundancia de materiales, recursos y opciones. Pero poco criterio para elegirlas. Así como la guerra es la obra de arte de los militares. La formación de maestros es el punto máximo en la perpetuación de la colonialidad.

\section{A MANERA DE CONCLUSIÓN...}

Con honestidad, no planteo soluciones, pero me esfuerzo en buscar salidas. Tampoco tengo una posición de poder, (que me haría correr el riesgo colonizador de la imposición). Pero puedo compartir algunas frases, de educadores extraordinarios, que quizá contribuyan a orientar algunas acciones:

Los cuestionamientos del Profesor Domingo Batres, para hacer pensar a sus estudiantes:

"Ni el agua hierve a los 100 grados, ni la tierra es redonda, ni Colón descubrió América,

ni los mayas hicieron ruinas...” ¿Falso o verdadero? ¿Por qué?

"Não acreditem em nada do que dizem os livros.

Não acreditem em nada do que dizem seus profesores.

Não acreditem em nada do que vocés veem ou pensam, e também não acreditem em nada do que eu digo!" Hans-Joachim Köellreutter (2017) "A pesar de que la idea de transgresión también podría estar relacionada a esto, creo que cuando las cosas son hechas de este modo, no son porque estamos contra algo, sino, mejor, por amor." Violeta de Gainza (2007)

Vuelvo al tema inicial de esta ponencia. Por suerte, la partitura no es la música, ni las políticas públicas constituyen la realidad de la educación. Dejemos la partitura a un lado, y vivamos el ritmo pleno, sin metrónomo. Rompamos la partitura. iEn nuestras manos está! 


\section{REFERENCIAS}

Aharonián, Coriún. (2000). Conversaciones sobre música, cultura e identidad. Montevideo, Uruguay. Ediciones Tacuabé.

Aharonián, Coriún.(2004). Educación, arte, música. Montevideo, Uruguay. Ediciones Tacuabé.

Castellani, Ana. (2019). Informe de investigación No. 6. $¿ Q u e ́$ hay detrás de las fundaciones y ONGs educativas? Las redes de influencia público-privadas en torno a la educación. Argentina. Observatorio de las élites. CITRA UMET-CONICET

Figueroa, Efraín. (2016). La marimba mesoamericana. Una historia ilustrada. Guatemala, C.A. Editorial Piedra Santa.

Gainza, Violeta H. de y Vivanco, Pepa. (2007). En música in-dependencia. Educación y crisis social. Buenos Aires, Argentina. Grupo Editorial Lumen.

González, Juan Pablo. (2018). Pensar la música desde América Latina. Problemas e interrogantes. Santiago de Chile: Ediciones Universidad Alberto Hurtado.
Köelreutter, Hans-Joachim. (2017) Pensamiento Pedagógico Musical Latinoamericano. Hans-Joachim Koellreutter. Guadalajara, México. FLADEM, Departamento de publicaciones.

Mignolo, Walter. (2005). La idea de América Latina. La herida colonial y la opción decolonial. Barcelona, España. GEDISA, Editorial.

Piedra Santa, Irene. (1988). El proyecto RTAC-II (19861991) para la América Central. Un comentario crítico. Guatemala. Fundación Leer.

Quijano, Aníbal. (2000). "Colonialidad del poder y clasificación social”. Journal of World-systems Research. 6/2

Taylor, Diana. 2017. El archivo y el repertorio. El cuerpo y la memoria cultural en las Américas. Santiago de Chile. Ediciones Universidad Alberto Hurtado.

Torres-Rivas, Edelberto. 2017. Guatemala: un edificio de cinco pisos. Guatemala. Catafixia Editorial.

Vega, Carlos. 1947. La forma de la cueca chilena. Santiago. Universidad de Chile. Colección Ensayos.2 


\section{Helber Rocha Rufino, Verônica Cabral da Silva}

\section{CIRANDA NA ESCOLA: UMA PRÁTICA DECOLONIAL EM EDUCAÇÃO ARTÍSTICA}

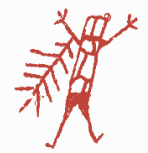

\section{INTRODUÇÃO}

No ano de 2016, na Escola Municipal Dolores Petrola de Melo Jorge, situada no bairro Granja Lisboa, Fortaleza - CE, escola inserida na comunidade Leonel Brizola, iniciamos um projeto de ação intensiva cultural oriundo das aulas de capoeira do Programa Mais Educação, como educador popular, onde, a princípio, trabalhávamos a cultura popular do Nordeste com foco nas danças: Samba de Roda, Ciranda, Carimbó e Torém. De todas estas danças a ciranda se destacou e permaneceu como projeto cultural da Escola.

A partir desse momento surgiu o Grupo Cultural de Ciranda da Escola Municipal Maria Dolores Petrola de Melo Jorge, com o intuito de vivenciar as manifestações culturais brasileiras, no ambiente escolar e no ensino de educação artística, trabalhando a preservação da cultura popular, tendo como orientação pedagógica uma prática decolonial de compreensão de saberes nacionais. O grupo é composto, em parte, por estudantes de 8 a 12 anos, do $3^{\circ}$ ao $5^{\circ}$ ano do Ensino Fundamental.

\section{DESENVOLVIMENTO}

A Ciranda é uma dança portuguesa que, ao chegar ao Brasil, sofreu transformações nas regiões em que foi difundida, tendo maior notoriedade no Estado de Pernambuco, segundo Loureiro e Lima (2018, p.396): “Embora a Ciranda brasileira conserve muitas características das antigas Cirandas portuguesas, ela é praticada em nosso país em diferentes formas e modalidades". As autoras ainda afirmam que: "A Ciranda é uma dança com características rítmicas e melódicas definidas. Apesar de sua relação com a cultura europeia, foi transformada e sincretizada com outras etnias formadoras das nossas culturas (europeia, africana e indígena). Sofreu influên- 
cia de outras danças e manifestações populares brasileiras, e é executada em festas religiosas e profanas, além de integrar parte do repertório infantil na modalidade de Ciranda de criança". A palavra Ciranda, segundo Callender (2013, p.121): "Para alguns estudiosos, funda-se na expressão "Ciranda" que teria origem na palavra espanhola "zaranda", instrumento para peneirar farinha, ou no vocábulo árabe "çarand", que significa: encadear, enlaçar, tecer coisas".

A manifestação por muito tempo era associada a dança infantil e esta característica foi sustentada por vários autores. A partir dos estudos de Jaime Diniz, ocorreu uma diferenciação da Ciranda/dança infantil, da Ciranda/cultura popular, e, em consonância com essa afirmação, Callender (2013, p.121), diz que "intelectuais como Mário de Andrade e Renato Almeida, segundo Jaime Diniz, acreditavam que a Ciranda no Brasil estava circunscrita na dança infantil, compreensão essa que foi refutada através de seu estudo publicado na cidade do Recife, em 1960. Essa obra revelou que havia uma prática cultural também denominada "Ciranda", sem se tratar de roda infantil. Era uma Ciranda tocada, cantada e bailada por adultos de ambos os sexos, práticas culturais, e que ocorria principalmente na região da Zona da Mata pernambucana”. Diferenciar a Ciranda/dança infantil da Ciranda/dança popular é necessário para que se possa abordar a experiência do grupo cultural de Ciranda que será discutido neste estudo, pois ainda se tem uma visão da Ciranda como uma parlenda do folclore, distanciando-se da Ciranda/dança popular.

\section{A EXPERIÊNCIA DO GRUPO CULTURAL DE CIRANDA DA ESCOLA MARIA DOLORES PETROLA DE MELO JORGE: PRÁTICA ARTÍSTICA DECOLONIAL.}

O pensamento decolonial na perspectiva cultural é o referencial teórico norteador deste estudo, pois visa desconstruir um arcabouço teórico-metodológico que foi construído para subalternizar o pensamento e os saberes de um povo sobre outro. Em consonância, Gallindo e Silva (2018, p.6,) afirma que: "O Pensamento decolonial surgiu a partir das lutas históricas dos povos indígenas e afrodescendentes que foram colonizados e que não se viam representados na História e na Ciência produzidas na Europa como um modelo universal. Desta forma, um grupo de intelectuais militantes latino-americanos sentiu a necessidade de se contrapor à hegemonia eurocêntrica do conhecimento, defendendo o protagonismo de outros modos de saberes, de ser e de poder". Trazendo essa concepção para a perspectiva cultural, muitas manifestações foram menosprezadas por um pensamento etnocêntrico, com o intuito de minimizar a sua importância e seus valores. Esse pensamento, segundo Abib (2019, p.7), "tornou-se uma potente expressão dos povos colonizados que começavam a tomar consciência de sua história, sua alteridade, sua identidade, seus modos de ser e estar no mundo enquanto pressupostos de sua existência”. 
A prática decolonial visa romper com as construções que foram feitas para apagar os saberes, os costumes e a cultura de um povo. É a partir dessa afirmação que o grupo da Ciranda nasceu para romper com essa visão no ambiente escolar e desconstruir estes conceitos. Em consonância com essa afirmação, Gallindo e Silva (2018, p.5), afirmam que: "[...] O Pensamento decolonial construiu um espaço para que outros modos de saberes, de ser e de viver sejam conhecidos e reconhecidos em sua originalidade como expressões fundamentais da humanidade".

O Grupo Cultural de Ciranda da Escola Municipal Maria Dolores Petrola de Melo Jorge, inserida na comunidade Leonel, localizada no bairro Granja Lisboa, na cidade de Fortaleza - Ceará, visava trabalhar outras manifestações culturais que complementassem as atividades culturais da Capoeira e de outras danças, transformando a escola num laboratório cultural. A Ciranda foi a manifestação cultural que as estudantes se identificaram mais, sendo esse o fator principal que levou os idealizadores do Projeto a escolherem esta dança como a manifestação principal a ser trabalhada na escola como atividade cultural intensiva e extensiva.

Antes de chegar ao ambiente escolar e entrar na comunidade em que está inserida, a equipe passou por vários desafios que foram cruciais para a sua projeção, atuação e consolidação. Os desafios a serem elencados foram: como as integrantes enxergavam a cultura popular e quais os impactos dessa visão sobre o grupo. Diante disso, os fatores socioculturais do bairro em que o grupo atua, como: religião e realidade social, contribuíram para a visão dessas alunas sobre a cultura.

A comunidade Leonel Brizola localiza-se num ambiente onde a presença do Estado é precária, favorecendo o aumento da pobreza, do crime organizado e da desigualdade social. Esses fatores compõem a formação sociocultural dos moradores e dos alunos da escola citada acima. Diante do exposto, as manifestações da cultura popular, principalmente, das afro-brasileiras, sofrem discriminação por parte de algumas famílias religiosas em virtude de suas origens. Algumas integrantes da equipe que eram oriundas de famílias religiosas tinham vergonha da manifestação e sofriam bullying no ambiente escolar.

Observamos que os fatores externos e internos eram as principais causas dos alunos terem uma visão negativa dessas expressões culturais, sendo assim, um dos focos da equipe era desconstruir as ações preconceituosas com a dança popular usando ferramentas como: vivência cultural, palestras de desconstrução, roda de conversas, o brincar, os festejos e as apresentações.

\section{METODOLOGIAS DECOLONIAIS: FERRAMENTAS PARA DESMISTIFICAR OS PRECONCEITOS E ESTIGMAS SOBRE A CULTURA POPULAR.}

No início dos trabalhos da Ciranda observou-se que ela era conhecida pelos alunos como parlenda "ciranda, cirandinha", bastante conhecida no ambiente escolar através 
do folclore. De acordo com Loureiro e Lima (2018, p.398), "As Cirandas Infantis são encontradas em todas as regiões brasileiras como brinquedo da infância. Elas aparecem mais como uma manifestação espontânea das crianças do que um repertório propiciado pela escola". O primeiro passo foi abordar a diferença entre a parlenda e a Ciranda como manifestação cultural mais ampla. O Grupo Cultural vem com essa proposta de desconstruir esse conceito e fazer ver que ela existe como manifestação cultural mais ampla.

A ludicidade que a Ciranda proporcionou às crianças no espaço escolar foi de suma importância, pois promoveu o brincar, o bem estar, a integração da coletividade e afetividade, na escola. Diante de tudo isso, "A brincadeira é essencial na vida das crianças. Por meio dela se comunicam consigo mesmas e com o mundo. É uma forma com que elas conseguem agir em grupo". (BRASIL, SILVA, GOMES, DANTAS, 2016, P.5), ou seja, a Ciranda transformou a escola num ambiente atraente para os estudantes, pois os mesmos tinham uma visão negativa desta manifestação cultural.

Sobre a manifestação cultural ter transformado o ambiente escolar num espaço de referência aos alunos, Colares (2019, p.15), apresenta a seguinte afirmação: “... Mas a escola, nos limites das possibilidades que encerra, pode ser um espaço privilegiado de valorização do profundo sentido popular incorporado nas manifestações populares que constituem o patrimônio cultural da humanidade, onde tem que estar inscrita a presença da voz oculta, que se liberta e representa a dimensão dos conflitos societais que constituem as nossas vidas e a nossa história".

Tratar sobre a questão racial no ambiente escolar, com destaque para a construção da autoestima e do empoderamento através da cultura popular, por meio de rodas de conversa, foi outra abordagem importante, pois as integrantes negras do cabelo crespo, sofriam e sofrem discriminação por conta do seu cabelo. Para isso foi criado um espaço de acolhimento e de construção da autoestima.

Como a Ciranda estava sendo bastante associada à religiosidade de matriz africana como a Umbanda e o Candomblé, foram feitas as oficinas e vivências com o intuito de abordar a intolerância religiosa. As vivências eram feitas em visitas a eventos de cultura afro-brasileiras em escolas e universidades, e abordavam a Umbanda e o Candomblé. Essas estratégias foram fundamentais para descontruir tais estigmas.

A preservação do patrimônio cultural no ambiente escolar, com destaque para a identidade, foram conceitos trabalhados com os integrantes, mostrando a eles como são importantes agentes da preservação da cultura na escola. De acordo com esse pensamento, Oliveira, Neto, Andrade (2018, p.72), diz que: "A consciência de que existe um patrimônio cultural e o reconhecimento deste é de fundamental importância para que o indivíduo possa desenvolver modos de preservar sua história individual e, posteriormente, como esta se inclui no coletivo. Segundo esse apontamento, o cidadão se apropria de sua história local e de outros meios, e tendem à consciência histórica e local bem como cultural". A autora ainda ressalta que "ao desenvolver estes processos, é importante o indivíduo tornar-se consciente desde pertencimento patrimonial, pois os vínculos gerados deste, com sentimentos, pos- 
sibilitam a valorização dos bens culturais e até mesmo o reforço da autoestima do grupo/comunidade ao qual pertencem". (OLIVEIRA, NETO, ANDRADE, 2018, P.72). Trabalhar isso foi fundamental para mostrar às integrantes e a comunidade escolar em geral a importância dessa manifestação cultural.

A percussão e a musicalidade na Ciranda são fatores que contribuíram para atraí-los a participarem da atividade cultural na escola. Todas as etapas da apresentação são escolhidas pelos alunos, tornando-os sujeitos participativos, motivando-os a participarem diretamente da brincadeira, sendo assim, uma vivência musical para os integrantes das mais variadas idades que compõem o grupo. Diante disso, Loureiro e Lima (2018, p.399), nos mostram que: "Com a vivência musical desde a mais tenra idade, a criança constrói e adquire conceitos rítmicos, melódicos, harmônicos, polifônicos, históricos, e de formas musicais". As aulas práticas de percussão e música nesta atividade cultural também podem integrar as aulas teóricas de educação artística na sala de aula, contribuindo para a eficiência do ensino e aprendizagem desta disciplina. Segundo Loureiro e Lima (2018, p.399), "Essas atividades poderão se transformar numa possível e sólida formação musical e o professor pode se constituir em um bom mediador na criação deste espaço, ou seja, a figura que auxilia a criança ou jovem a se colocar como sujeito participante de um processo educativo". A música, na Ciranda, é muito envolvente e contribui de maneira significativa para a interação dos participantes nas expressões corporais da dança, pois a musicalidade da Ciranda cria um elo entre corpo e música, cria-se um pertencimento pela dança proporcionado pela musicalidade. De acordo com o exposto, Loureiro e Lima (2018, p.399), afirma que: "Na música a criança encontra elementos que lhe permite descobrir e reencontrar seu corpo físico; ela se reconhece como ser que pode perceber, ouvir, criar, movimentar, interagir diretamente num determinado espaço; adquire habilidades e comportamentos criativos e críticos que irão contribuir para o seu desenvolvimento integral". Um exemplo é o repertório musical trabalhado na Ciranda como: Lia de Itamaracá, Mestre Baracho, Mestre Geraldo, Capiba, Caetano Veloso, Dorival Caimy, Clara Nunes e Sergio Sampaio, é uma das formas de se trabalhar a música popular brasileira na escola, enriquecendo a prática pedagógica cultural escolar e valorizando a música popular brasileira.

\section{ATIVIDADE INTENSIVA E EXTENSIVA DA CULTURA NA ESCOLA: MERCADOLOGIA DE IMPACTO CULTURAL DECOLONIAL NO ENSINO DAS ARTES NO AMBIENTE ESCOLAR.}

O impacto educacional que a cultura tradicional proporciona no ambiente escolar quando é trabalhado de forma intensiva e extensiva é imediato, pois a escola, em geral, passa a integrar e a interagir com as atividades. $O$ trabalho constante da cultura popular na escola passou a ganhar espaço na vida socio cultural das integrantes, dos 
alunos e da comunidade, como lembra Colares (2019, p.69): "As escolas deveriam fazer a transmissão destes saberes populares de grande valia para a comunidade como prática social e de convivência recíproca e de atitude lúdica e estética".

As apresentações mostraram para os integrantes o potencial, o valor e a importância que elas tinham para a preservação da cultura popular na escola e na sociedade. A participação da família dos integrantes diante da repercussão das apresentações foi um fator decisivo para aproximar os familiares da escola ao acompanhar as atividades. Como resultado, a criação de mecanismos como: reuniões, participação em apresentações e divisão de atividades da equipe com os familiares, proporcionou a aproximação com a comunidade aumentando o conhecimento e a importância da equipe para com o corpo social. De acordo com Colares (2019, p.47), "A manutenção e o revigoramento de formas culturais tradicionais, que são legítimas no ambiente escolar, não só cumprem a função de salvaguardar o patrimônio imaterial de um povo, mas também criam os elementos identitários das gerações atuais, sem romper com os elos que nos fazem manter uma vida múltipla de significados".

A experiência do Grupo Cultural de Ciranda demonstrou ser uma metodologia que favorece uma aprendizagem emancipadora, pois visa desmistificar a construção pejorativa e estigmatizante sobre a cultura popular, principalmente as que carregam traços afro-brasileiros. É construído um espaço de reflexão no ambiente escolar que permite aos educandos e educadores fazerem uma reflexão sobre a cultura popular na escola. As formações e vivencias que são realizadas com os partícipes do grupo são práticas que visam aos integrantes obterem consciência crítica sobre o contexto cultural em que vivem e que possam tornar-se seres críticos e criativos. Tem, também, a finalidade de que os brincantes possam disseminar o seu aprendizado em outros locais, principalmente, em instituições escolares por onde passarem, e que possam criar outras práticas da cultura popular em espaços educativos.

\section{CULTURA DE MASSA E CULTURA TRADICIONAL: O IMPACTO DA CIRANDA COMO UMA PRÁTICA CULTURAL DECOLONIAL NA ESCOLA E NA COMUNIDADE.}

A cultura de massa é a mais consumida pelos estudantes da comunidade escolar. Com o início da vivência da Ciranda foi sentida uma diferença entre a cultura popular e a cultura de massa entre os estudantes, ocorrendo casos de preconceitos e bullying. Calixe, Fialho, Santana (2014, p.16,) afirmam que: "A cultura popular apresenta sempre relações de tensão com a cultura dominante". Com o trabalho da Ciranda a cultura tradicional ganhou espaço e passou a ser protagonizada no espaço sociocultural da escola e da comunidade.

A cultura de massa reproduzida no ambiente escolar acaba ofuscando e apagando as práticas culturais tradicionais quando estas não são trabalhadas de forma 
intensiva e extensiva. Baseado nessa problemática, o Grupo Cultural de Ciranda foi um dos mecanismos educacionais culturais usados para reverter essa situação. Desde 2017, o Grupo de Cultura Popular também procura valorizar as raízes culturais diante da predominância da cultura de massa. Uma visão de mundo é construída a partir do trabalho cultural na escola, mostrando para os integrantes o universo de manifestações culturais que nosso país detém e como é importante preservá-las. É nessa perspectiva que é trabalhada a identidade e o pertencimento cultural, que são mecanismos fundamentais para trabalhar o conhecimento de nossa diversidade cultural.

A escola é um espaço de grande importância para a preservação da cultura popular e uma grande aliada para não deixar essas tradições acabarem. As manifestações culturais sendo trabalhadas como práticas educacionais de lazer e entretenimento, terão grandes resultados no ambiente escolar e comunitário. Para Colares (2019, p.30): "Brincadeiras, canções, danças, representações próprias da cultura popular e da vida comunitária nas situações de festa, são ricos mananciais de expressões e práticas coletivas que servem de base aos saberem culturais e artísticos que devem ser repassados às crianças." É a partir dessas práticas que temos a oportunidade de debater com os estudantes sobre o apagamento da cultura popular tradicional em relação a cultura popular de massa, que é um dos focos de atuação da Ciranda. As apresentações são de fundamental importância, pois é nesse momento que os brincantes irão colocar em prática tudo que aprenderam durante as oficinas, vivências, aulas e ensaios, mostrando para o público o seu potencial e sua atuação de preservação da cultura nacional.

O Projeto da Ciranda passou a tornar a escola um espaço de resistência cultural. Colares alerta para que (2019, p.26): "Há uma total desvinculação entre festas comunitárias e escolas, até porque os principais ciclos festivos se dão nas férias. Apenas iniciativas de alguns heroicos educadores quebram o lugar comum. Na melhor das hipóteses, o folclore aparece no Jardim da Infância ou como atividade extraclasse e, até mesmo, a arte, no geral, só tem lugar nas aberturas ou encerramentos de cerimônias oficiais e burocráticas". Para o projeto aqui exposto a escola é um espaço fundamental para a preservação das nossas tradições.

\section{ATIVIDADES INTERNAS E EXTERNAS: O RESULTADO DAS ATIVIDADES NA ESCOLA E NA SOCIEDADE.}

As atividades do Grupo Cultural de Ciranda na Escola são realizadas em dois ambientes: na escola, como atividade interna, e na comunidade, como atividade externa. Durante as apresentações externas do Grupo de Ciranda, foi notória a surpresa positiva entre os estudantes, professores e gestores, com a atuação da manifestação da dança.

A ausência de grupos culturais populares nas escolas é uma das problemáticas na comunidade escolar. Segundo Colares (2019, p.34), "A análise da inserção das manifestações da cultura popular no trato do ensino de arte na escola básica bra- 
sileira tem demonstrado o enfraquecimento deste conteúdo como pertinente ao campo do conhecimento das Artes, aspecto que preocupa os estudiosos do tema, uma vez que a Arte é parte da produção cultural humana e que, como tal, é situada histórica e socialmente".

\section{CONSIDERAÇÕES FINAIS}

O Grupo Cultural da Ciranda na Escola surge com uma proposta pedagógica de se trabalhar a cultura popular na escola e socializá-la com a comunidade. Durante a passagem do Grupo por diversas escolas e instituições surgiram propostas por parte de professores e diretores para a implantação de grupos de Cirandas nesses espaços educativos. Diante disso, podemos notar a ausência de manifestações artísticas no âmbito escolar.

O fato de nas atividades externas sempre ir acompanhando um familiar de um dos integrantes da equipe começou a aprofundar a relação da comunidade com o Grupo Cultural de Ciranda na Escola. Durante a preparação dos brincantes nas apresentações internas e externas, os familiares são chamados para colaborarem. Nas festas e confraternizações da escola a participação da família também é regular. A partir desta experiência percebemos que a Ciranda tem uma ligação forte com a comunidade onde está inserida, sendo assim, o projeto aprofundou o elo entre escola-família. Demonstrou-se, também, como uma oportunidade da comunidade se identificar nos saberes da cultura popular e apoiar a escola na difusão cultural na comunidade.

Concluímos que a experiência do Grupo Cultural de Ciranda na Escola é uma prática pedagógica que deve ser permanente, e deve ser expandida a outras escolas. O Grupo é um mecanismo de enfrentamento à descaracterização da cultura tradicional no ambiente escolar e uma forma de inovar a abordagem dessa cultura nas instituições escolares. Também é uma forma de trabalhar o elo entre escola e comunidade em prol do resgate da cultura popular em ambos os espaços, fortalecendo a necessidade de preservar as nossas tradições. O brincar, na Ciranda, é uma interação com as festas populares tradicionais, pois a ludicidade é um modo próprio dessas manifestações e por isso é fundamental fomentar essa prática numa escola atraente e prazerosa.

A experiência do Grupo de Ciranda é um exemplo e um modelo para trabalhar a cultura tradicional na escola, tendo como metodologia atividades intensivas e extensivas, ampliando, assim, a qualidade do ensino da Arte e da cultura popular no ambiente escolar, atingindo o seu objetivo, dando qualidade e efetividade ao trabalho. Também é uma oportunidade para repensar a formação dos professores na área da Arte e da cultura em ambiente escolar, ampliando o leque de profissionais dispostos a trabalhar a cultura popular em sala de aula. É um exemplo para 
que as Secretarias de Educação e Cultura façam parcerias para apoiar essas práticas pedagógicas com o intuito de valorizar tais manifestações, bem como a formação do professor.

A Ciranda é uma referência para a prática das manifestações artístico populares muito ausente no ambiente escolar. A prática da Ciranda, que neste projeto é realizada nos anos iniciais, também pode ser referência a ser vivenciada nos segmentos finais do Ensino Fundamental e no Ensino Médio. A escola como um todo poderá se beneficiar da abordagem da cultura popular, em especial da Ciranda na Escola.

Diversos aspectos educativos podem ser destacados na vivência da Ciranda na Escola, desde os afetivos, que alteram diretamente o interesse pela escola, a integração social, atingindo também a família e a comunidade, afetando, especialmente, aos conteúdos da área de conhecimento, de Arte, na aprendizagem escolar, dentre outra possibilidades interdisciplinares que um trabalho como este pode englobar.

\section{REFERÊNCIAS}

CALLENDER, Déborah. Histórias da ciranda: silêncios e possibilidades. Textos escolhidos de cultura e arte populares, Rio de Janeiro, v.10, n.1, p. 113132, mai. 2013.

LOUREIRO, Maristela; LIMA, Sonia Albano de. As cirandas brasileiras e sua inserção no ensino fundamental e nos cursos de formação de docentes. Universidade do Estado de Santa Catarina. DAPesquisa, 01 October 2018, Vol.7(9), pp.393-410.

GALLINDO, Lucione Santiago; SILVA, Auxiliadora M. M. da. Pedagogia Decolonial - Kanteatro: prática de uma educação antirracista. 2018. Disponível em: https://www.ufpe.br/documents/39399/2442885/ GALINDO_+SILVA+-+2018.2+.pdf/085cd886-9592-4314-94f7-eb2ee2f15c6f Acesso em: 18 de novembro de 2020.

BRASIL, Mario Lima; SILVA, Débora Pontes da; GOMES, José Donizete; DANTAS, Rafaela. Reflexões Sobre a Percussão Corporal $\mathrm{Na}$ Escola Municipal Aleixo Pereira Braga II. Brasil. Conexões Culturais - Revista de Linguagens, Artes e Estudos em Cultura - V. 02, no 01, ano 2016, p. 372-379.
ABIB, Pedro Rodolpho Jungers. Culturas Populares, Educação e Descolonização. Rio G. do Norte. Revista Educação em Questão, 01 November 2019, Vol.57(54).

COLARES, Edite. As festas populares e o ensino de arte. EdUECE: Fortaleza, 2019.

OLIVEIRA, Dayana Silva de; NETO, João Alves Leite; ANDRADE, Francisco Ari de. O projeto Patrimônio Para Todos Como Um Diálogo Intercultural Para Valorização Dos Bens Culturais: Caminhos Para a Educação Patrimonial No Ceará. In: VASCONSELOS, José Gerardo; SANTANA, José Rogério; FIALHO, lia Machado Fiuza (Org.). História e Práticas Culturais na Educação. - Fortaleza: EdUECE, 2014.

CALIXE, Carlos Rafael Vieira; FIALHO, Lia Machado Fiuza; SANTANA, José Rogério (Aut.). Africanos e Afrodescendentes: Espaços de Cultura, Resistência e Sociabilidade. - Fortaleza: Edições UFC, 2014. 


\title{
Ilda Lima de Sousa, Inês Cavaco
}

\section{EDUCAÇÃO ARTÍSTICA E (DES)COLONIALIDADE: EXPERIÊNCIA NA COMUNIDADE QUILOMBOLA DE CONCEIÇÃO DAS CRIOULAS ${ }^{1}$}

\author{
PALAVRAS-CHAVE \\ Educação Artística; Decolonialidade; Quilombo \\ NOTA INTRODUTÓRIA
}

Perante o tema proposto para o IV ei_ea, desejamos realizar uma partilha de vivência que, pelos constrangimentos provocados pela pandemia, não nos foi possível realizar presencialmente. Este texto procura, por isso, traduzir essa vivência e revisitar um conflito particular que surge durante a nossa jovem experiência na Comunidade Quilombola de Conceição das Crioulas (CQCC) e, em continuidade, abrir discussão em torno das questões que daí surgem e nos acompanham no nosso quotidiano e meio académico.

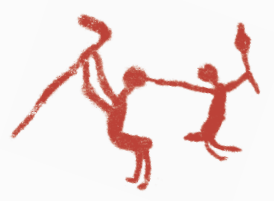

${ }^{1}$ Este texto é a continuidade e formalização de uma reflexão conjunta que até ao momento se apresentava numa aparência individual:

CAVACO, I. À escuta. In: AQCC, I2aDS e (Org.). Nova partilha de reflexões sobre as Artes, a Luta, os Saberes e os Sabores da Comunidade Quilombola de Conceição das Crioulas. Porto e Salgueiro: i2ADS e AQCC, [s.d.].

SOUSA, I. Material que pode ser facilmente moldado ou deformado, obtido com uma substância sólida, misturada com uma substância líquida. In: AQCC, I2ADS e (Org.). Nova partilha de reflexões sobre as Artes, a Luta, os Saberes e os Sabores da Comunidade Quilombola de Conceição das Crioulas. Porto e Salgueiro: i2ADS e AQCC, [s.d.].

SOUSA, I. De. Material obtido com uma substância sólida, misturada com uma substância líquida. In: UFPE (Org.). Anais do IV SIOMSAL. Caruaru: UFPE- CAA, 2019, p. 281-283. 
Tendo a história e a cultura da comunidade ${ }^{2}$ em consideração pensámos realizar, durante o II Encontro com as Artes, a Luta, os Saberes e os Sabores da Comunidade Quilombola de Conceição das Crioulas (2019), uma oficina onde a mulher fosse o tema central enquanto possibilidade de abordar a luta feminina tão presente ao longo da sua história.

Nós e alunas/os, professoras e funcionárias da Escola Quilombola Municipal Bevenuto Simão de Oliveira, do sítio Paula, construímos colaborativamente uma boneca em pasta de papel que procurou representar e homenagear a avó Roxinha, uma mulher com muitos anos de sabedoria da comunidade, avó de pelo menos 6 meninas/os da sala e conhecida e querida por todas/os elas/eles.

Durante a construção do objeto, vimo-nos perante o desejo das/os alunas/os em representar a Avó Roxinha com uma cor de pele clara e cabelos lisos, características menos presentes na comunidade. Daí gerou-se uma discussão em torno das questões “Que cor de pele?", "Que tipo de cabelo?”. Essas questões e outros momentos na escola fizeram-nos confrontar com a existência de padrões ocidentais que ali talvez quisessem ser representados. Que imagens e imaginário estarão por trás deste desejo?

No decorrer da oficina aconteceram vários momentos transversais a outros contextos e naturais no comportamento de uma criança perante uma/um adulta/o e/ou estranha/o e, consequentemente, as representações de padrões externos podem ter sido apenas provocadas e influenciadas por um interesse inofensivo em deixar, de alguma forma, a nossa passagem ali representada. Contudo criou-se a oportunidade de questionar a nossa presença enquanto mulheres brancas europeias na comunidade cuja história é de luta e resistência feminina perante privações e injustiças cometidas pelos sistemas patriarcais, hegemônicos e racistas promovidos pelos impérios coloniais.

Voltando a atenção ao contexto para o qual nos deslocamos e o qual nos fez deslocar, compreendemos a necessidade de olhar para a memória, nossa e da comunidade, como ferramenta para enfrentar as várias questões surgidas a partir da vivência aqui apresentada.

\section{MEMÓRIA HISTÓRICA}

Le Goff (1990) lembra-nos que as narrativas que chegaram até nós, do passado, prendem- se num tempo-espaço que já não existe mais e construíram-se por meio de escolhas em intensos trabalhos de construção e reconstrução sobre as vivências passadas.

Fomos para aquele contexto a partir de um lugar onde as estratégias de representação do nosso passado resultaram em encenações históricas. Como refere o

${ }^{2}$ Contam os mais velhos que o Quilombo teve origem no início do século XVIII, com a chegada de seis negras à região guiadas por Francisco José, um escravo rebelado. 
professor José Paiva, em Portugal, nunca quisemos entender o que promovemos enquanto colonizadores (PAIVA, 2018, p. 36).

Uma grande indústria didática trabalha para ajudar os jovens estudantes a lembrar/esquecer as hostilidades europeias. Os nossos manuais escolares, os manuais portugueses, oferecem um espetáculo de um país que descobre o mundo, de um país heroico. Porém os mesmos livros didáticos não informam as especificidades dessa "descoberta", omitem o sofrimento dos povos explorados, tratam-nos como mercadoria e mascaram tudo isso com a denominação de "trocas".

A memória é um elemento essencial do que se costuma chamar identidade, individual ou coletiva, cuja busca é uma das atividades fundamentais dos indivíduos e das sociedades de hoje, na febre e na angústia. Mas a memória coletiva é não somente uma conquista é também um instrumento e um objeto de poder. São as sociedades cuja memória social é sobretudo oral ou que estão em vias de constituir uma memória coletiva escrita que melhor permitem compreender esta luta pela dominação da recordação e da tradição, esta manifestação da memória (GOFF, LE, 1990, p. 476).

As nossas memórias vêm do cerne de instituições ocidentais opressoras que continuamente recusam o reconhecimento da diversidade como unidade, agindo discriminatoriamente sobre etnias não-brancas, população LGBTI+, comunidades religiosas, e outros grupos de minorias sociais, ao invés de criar um sistema que assume a diversidade de saberes, de fazer e de pensar, e de modos de ser-estar como benéficos para a comunidade local e global.

Pelo contrário, a memória de Conceição das Crioulas foi sobretudo construída, por meio de heranças orais, que se traduziram em lutas pelos seus direitos humanos, territoriais e educacionais. A sua produção cultural, como o artesanato, ao mesmo tempo que serve como fonte de rendimento, conta a história da comunidade e acentua um esforço liderado sobretudo pela mulher. Nas escolas, as professoras e os professores, usufruem do resultado das várias lutas por uma educação diferenciada que respeite a história e a cultura local.

Entendemos que somos comunidades étnicas, com nossas crenças, jeito de falar, comer, rezar, celebrar e brincar, com lutas e saberes diferentes da sociedade envolvente, dentro de uma diversidade que é rica na criatividade, respeito e resistência. Por isso, a nossa escola deve ser pensada do nosso jeito, como instrumento da nossa luta pelos nossos territórios, na valorização da nossa identidade étnica e dos saberes e histórias transmitidas pelas pessoas mais velhas, buscando a melhoria da qualidade de vida para cada quilombo. (CARTA DE PRINCÍPIOS DA EDUCAÇÃO ESCOLAR QUILOMBOLA DE PERNAMBUCO, 2009) (NASCIMENTO, 2017, p. 79). 
A Educação Quilombola é uma grande conquista, num contexto de memória escravista, como é o Brasil, onde se aboliu política e juridicamente o sistema de subordinação direta do corpo cativado, mas onde permanece a sua forma social correspondente, pelas várias formas de aversão à diferença, definida como inimiga, cromaticamente demarcados e existencialmente colocados em posições subalternas (SODRÉ, 2018).

Por isso, as memórias dos dois contextos em questão, a nossa e a da comunidade, carregam políticas que optaram e optam pela diferenciação entre seres humanos em torno da ideia de raça criada e explorada durante um vasto tempo histórico de feitos colonizadores. Sermos recebidas naquele contexto poderia ter-se verificado controverso, não fosse os anos construídos em torno dos três c's - conhecimento, confiança e cumplicidades - entre a comunidade e o grupo Identidades.

Portanto, o nosso deslocamento até lá resultou de um entendimento daquilo que promovemos enquanto colonizadoras e fez-se acompanhar de uma vigilância, atentas às nossas ações, nossa maneira de entender e relacionar com a comunidade.

Achille Mbembe, em Crítica da Razão Negra (2017, p. 146), a partir das reflexões de Fabien Eboussi Boulaga, sobre "tradição", em de La Crise du Muntu, fala-nos sobre a ideia de memória vigilante que é fundamental para impedir a repetição.

E é com essa vigilância que voltamos a reviver a experiência através da escrita, na procura de uma consciência de nós mesmas e uma auto vigia dos possíveis códigos hegemônicos europeus em nós presentes, por nós praticados. Ao ler The Mask, de Grada Kilomba (2010) percebemos que muitas vezes colocamo-nos de fora de uma atitude colonizadora, remetendo essa prática apenas aos nossos antepassados. Grada Kilomba alerta-nos que esses são discursos que nos permitem manter sentimentos positivos em relação a nós mesmos e que, ao mesmo tempo, impedem um reconhecimento e reparação da realidade, mantendo-nos atrás de um conforto de uma qualidade neutral.

Quando nós ocidentais nos escondemos atrás desse conforto apreendido não estamos a reconhecer que a nossa trajetória não é neutra, mas sim limitada, dominante e a partir de um lugar que reflete interesses políticos de uma sociedade branca, colonial e patriarcal (KILOMBA, 2016). A nossa estadia lá foi por isso, um tempo-espaço de reconhecimento, provocado por "experiências que colocam em questão nossas preconcepções sobre nós mesmos(as) e nos obriga a nos ver através dos olhos de outros(as), nos ajudando a reconhecer a discrepância entre a percepção de outras pessoas sobre nós e nossa própria percepção de nós mesmos(as)” (KILOMBA, 2010).

\section{NA OFICINA}

Assumimos a oficina como um espaço de práticas que pode ser (re)produtiva mas também criativa, construtiva e/ou (repara)tória. A análise de uma oficina compreende vários procedimentos também eles oficinais, seja nos aspectos que an- 
tecederam o seu desenvolvimento, no próprio desenvolvimento da oficina, ou no momento de registo e análise pós-oficina. Este último respeita mecanismos ainda menos neutros. As nossas vivências e o nosso envolvimento contaminam a interpretação dos acontecimentos cativos numa memória já construída e manipulada. Além de tudo, o mundo ocidental determinou- nos, de alguma forma, a olhar um problema a partir de um conjunto de ferramentas pré- definidas e que fixa a forma como lemos uma determinada questão. Contudo, a oficina assume-se aqui como um espaço de construção, onde re-interpretamos os ideais europeias, onde pretendíamos respeitar o pensar-fazer da comunidade.

A oficina propunha a representação das mulheres da comunidade, ou especificamente de uma, respeitando a proximidade tempo-espacial das crianças. Uma vez que nós não conhecemos a pessoa escolhida para ser representada, procurámos chegar às suas características através do desenho e do diálogo com as crianças. Apenas percebemos a dissemelhança que estava a ser representada a partir da conversa entre professoras e alunas/os. Enquanto as professoras procuravam uma cor mais escura para pintar a pele, as crianças escolhiam uma cor clara, possivelmente influenciadas pela nossa presença ou por um qualquer imaginário que permanece até hoje sobre a pele branca e a pele negra. Sabemos que o tempo-espaço daquela escola é uma realidade de grande proximidade com as lideranças femininas que lutam e resistem ao (des) governo genocida regente no brasil. Porém, ainda que o acontecimento nos cause alguma estranheza pelo seu contexto, estamos também cientes de que a nossa presença na comunidade carrega um peso histórico. Esse peso, desafia-nos a pensar a partir de algumas questões que nos foram surgindo. Estaria a operar um desejo inocente de aproximar a imagem da boneca à nossa imagem, enquanto pessoas novas naquela sala de aula? Teremos ficado nós no lugar do exótico? Como medir a serenidade desse desejo de aproximação? Que outras motivações, menos inocentes, poderiam estar por trás do desejo dessa forma de representação? Continuam os padrões ocidentais inevitavelmente a atingir o "pensar-fazer" do quilombo?

Em "Performing Essentialism at documenta 12", Hansel Sato fala sobre o desconforto que sentiu aquando vários alemães percepcionaram que seria um não-europeu a realizar a visita-guiada na documenta 12, em Kassel, na Alemanha. Este acontecimento remete- nos para a oficina que realizámos. Hansel Sato pensou esconder a sua nacionalidade, contudo o seu fenótipo denunciava-o. Pensamos em como a nossa presença, a presença de duas mulheres brancas, poderia ter influenciado na experiência da oficina.

Os impérios coloniais procuraram uma supremacia fenóptica da pele branca sob a pele negra. Sabemos que essa procura não se deu apenas através de privilégios e privações, mas também de uma demanda do predomínio da civilização europeia sobre outros continentes através de uma busca de autoridade fenotípica, estética, científica e terrestre. 
Nenhuma cultura no mundo permaneceu intacta perante a modernidade europeia. Não há em absoluto, como estar fora do sistema. O monologismo e o desenho monotópico global do Ocidente relacionam-se com outras culturas e povos a partir de uma posição de superioridade e são surdos às cosmologias e epistemologias do mundo não-ocidental. (SOUSA SANTOS, DE; MENESES, 2009, p. 406)

Na Europa do século XIX pessoas negras eram exibidas em eventos sociais. Saartjie Baartman, por exemplo, do povo Khoisan, foi trazida de África para ser exibida numa feira de curiosidades e aberrações em Londres, com o título de "Vênus de Hotentote". Mais tarde é também exibida, no Museu do Homem, em Paris, e estudada sob uma teoria que queria alegar uma anormalidade do corpo da mulher negra em comparação ao corpo do homem europeu, considerado a normalidade, e uma superioridade da raça caucasiana que lhe atribuiria o direito e dever de colonizar outras raças consideradas inferiores (CURADO, 2018).

Em 1934, no Porto, decorria a Primeira Exposição Colonial Portuguesa no Palácio de Cristal, cujo catálogo equiparava a colonização com a migração animal. A exposição foi acompanhada por um discurso de Henrique Galvão ${ }^{3}$ no Palácio da Bolsa (na época Palácio das Colónias) ${ }^{4}$.

A partir destes acontecimentos é possível abrir um outro espectro de compreensão. A influência deste processo de repressão/opressão, cometido ao longo da história, tem reverberações ainda no presente. Por isso, consideramos olhar para o desejo de representação de uma mulher da comunidade com uma cor de pele mais clara como um episódio de negação de um fenótipo presente na comunidade desde a sua origem, reflexo da supressão cometida ao longo da história.

Da vivência na oficina surge-nos ainda uma outra questão que não nos pode ser indiferente: se deveríamos ou não intervir ou participar, enquanto mulheres brancas, numa discussão sobre representação e cor de pele de uma mulher da comunidade quilombola. Nos últimos tempos o tema Lugar de Fala tem sido muito explorado e polémico (RIBEIRO, 2017). Entendendo o discurso como um mecanismo de manutenção de poder, no sentido Foucaultiano, poderíamos intervir?

\footnotetext{
${ }^{3}$ Henrique Galvão foi militar com experiência no colonialismo, diretor das Feiras de Amostras Coloniais e que representou Portugal na Exposição Colonial de Paris em 1931.

${ }^{4}$ Sobre o Império Português na primeira Exposição Colonial Portuguesa, o álbum-catálogo oficial está disponível em: http://hemerotecadigital.cm- lisboa.pt/RaridadesBibliograficas/OImperioPortugues/ OImperioPortugues_item1/P41.html e outras informações estão disponíveis em: http://hemerotecadigital.cm- lisboa.pt/EFEMERIDES/exposicaocolonial/exposicaocolonial.htm
} 


\section{REFERENNCIAS}

CURADO, V. L. A Vénus Hotentote, o seu Público e a Ciência. Filhos do Império e Pós- Memórias Europeias. [S.1.]: Memoirs, 2018.

GOFF, J. LE. História e Memória. Campinas, São Paulo: Unicamp, 1990.

KILOMBA, G. The Mask. Cadernos de Literatura em Tradução, 2010. n. 16, p. 171-180.

. Descolonizar o conhecimento. Uma Palestra-Performance de Grada Kilomba . CCSP - Centro Cultural São Paulo.

MBEMBE, A.; LANÇA, M. Crítica da Razão Negra. Lisboa: Antígona, 2017.

MIGNOLO, W. D. Colonialidade: O lado mais escuro da modernidade* ${ }^{*}$ Revista Brasileira de Ciências Sociais, 2017. v. 32, p. 1-18.

NASCIMENTO, M. J. Do. Por uma Pedagogia Crioula: Memória, Identidade e Resistência no Quilombo de Conceição das Crioulas - PE. Brasília: Universidade de Brasília, 2017.

PAIVA, J. C. De. Entender a resistência na Educação Artística como acção inscrita na erradicação de possibilidades a partir do vivido pelo '4 EI_EA. In: PAIVA, J. C. De; COUTO,

L. (Org.). Encontrar sentidos na experiência partilhada em Cabo Verde. Porto: i2ADS, 2018, p. 43-50.

RIBEIRO, D. O que é Lugar de fala? Belo Horizonte: Letramento, 2017.

SAMPAIO, A. B.; MENDONÇA, E. De C. Democracia Cultural, Museu e Patrimônio: Relações para a Garantia dos Direitos Culturais. In: VELOSO, A. S. (Org.). 30 Museus e democracia cultural. Coimbra: Centro de Estudos Sociais, Universidade de Coimbra, 2018, p. 14-38.

SODRÉ, M. Uma lógica perversa de lugar. Rio de Janeiro: Revista ECO-Pós, 2018. v. 2, n. 2175-8689, p. 9-16.

SOUSA SANTOS, B. DE; MENESES, M. P. Epistemologias do Sul. Coimbra: Almedina, 2009.

WILLIAMS, C. Maps have 'north' at the top, but it could've been different. 2016.indiferente: se deveríamos ou não intervir ou participar, enquanto mulheres brancas, numa discussão sobre representação e cor de pele de uma mulher da comunidade quilombola. Nos últimos tempos o tema Lugar de Fala tem sido muito explorado e polémico (RIBEIRO, 2017). Entendendo o discurso como um mecanismo de manutenção de poder, no sentido Foucaultiano, poderíamos intervir?
CURADO, V. L. A Vénus Hotentote, o seu Público e a Ciência. Filhos do Império e Pós- Memórias Europeias. [S.1.]: Memoirs, 2018.

GOFF, J. LE. História e Memória. Campinas, São Paulo: Unicamp, 1990.

KILOMBA, G. The Mask. Cadernos de Literatura em Tradução, 2010. n. 16, p. 171-180.

. Descolonizar o conhecimento. Uma Palestra-Performance de Grada Kilomba . CCSP - Centro Cultural São Paulo.

MBEMBE, A.; LANÇA, M. Crítica da Razão Negra. Lisboa: Antígona, 2017.

MIGNOLO, W. D. Colonialidade: O lado mais escuro da modernidade* ${ }^{*}$. Revista Brasileira de Ciências Sociais, 2017. v. 32, p. 1-18.

NASCIMENTO, M. J. Do. Por uma Pedagogia Crioula: Memória, Identidade e Resistência no Quilombo de Conceição das Crioulas - PE. Brasília: Universidade de Brasília, 2017.

PAIVA, J. C. De. Entender a resistência na Educação Artística como acção inscrita na erradicação de possibilidades a partir do vivido pelo '4 EI_EA. In: PAIVA, J. C. De; COUTO,

L. (Org.). Encontrar sentidos na experiência partilhada em Cabo Verde. Porto: i2ADS, 2018, p. 43-50.

RIBEIRO, D. O que é Lugar de fala? Belo Horizonte: Letramento, 2017.

SAMPAIO, A. B.; MENDONÇA, E. De C. Democracia Cultural, Museu e Patrimônio: Relações para a Garantia dos Direitos Culturais. In: VELOSO, A. S. (Org.). 30 Museus e democracia cultural. Coimbra: Centro de Estudos Sociais, Universidade de Coimbra, 2018, p. 14-38.

SODRÉ, M. Uma lógica perversa de lugar. Rio de Janeiro: Revista ECO-Pós, 2018. v. 2, n. 2175-8689, p. 9-16.

SOUSA SANTOS, B. DE; MENESES, M. P. Epistemologias do Sul. Coimbra: Almedina, 2009.

WILLIAMS, C. Maps have 'north' at the top, but it could've been different. 2016. 


\section{José Carlos de Paiva}

\section{DESLOCAÇÃO DE SI \\ E A INSCRIÇÃO EM PRÁTICAS ANTICOLONIAIS}

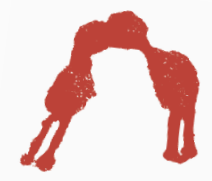

Não há no mundo um pobre desgraçado linchado, um pobre homem torturado em que não seja eu

também assassinado e humilhado.

Aimé Césaire

Em muitos sentidos, sou um ser desconhecido, ocultando de mim próprio aquilo que não me conforta e que quero desnudar. Tenho dificuldade em entender, para além da sua superfície as ideias que me povoam, sem no entanto ter nenhum medo de enfrentar as fragilidades próprias, de arriscar e em voz alta revelar o que me inquieta, e o que mal-entendo. Com esta irresponsabilidade assumida, apelo para uma leitura aberta, traduzida pela sabedoria de cada um.

Ao longo de muitos e preenchidos anos, em que este corpo de jovem se moveu por caminhadas voluntariosas, fui sendo construído no sujeito que sou, demasiado convencido que as ideias, os projectos e as acções que me povoaram, resultavam numa lucidez crítica, que me permitia ser eu próprio. Quase me convenci de poder ser imune aos dilúvios por que passei na vida, no contexto da família a que pertenço, nas escolas por onde andei, nos círculos de amizade onde me situei, nos terrenos institucionais que frequento, nas relações profissionais que estabeleci. A militância anti-capitalista e anti-colonial, afastou-me do adormecimento sedutor que me era oferecido pela ascensão social conseguida, que me aliciava para uma felicidade alienada e um bem-estar de tranquilidade.

Esse caminho aproximou-me de outras vozes, do pensamento crítico e da acção contra-hegemónica, que integra a história do mundo ocidental, das lutas anti-coloniais e das práticas descolonais. O que sou, muito o devo aos tropeções e, essencialmente, às boas camaradagens, às leituras e às discussões a que tive acesso, aos acontecimentos em que fui parceiro e cúmplice, e nos que presenciei. 
Nessas encruzilhadas, imerso nas tecnologias de governo que me cercaram e noutras instâncias partilhadas de atenção, me tornei o que sou. Consciente da incompletude como sujeito, ávido de ter... a arte de não ser governado ou a arte de ná̃o ser governado assim e a esse preço (FOUCAULT, 2017, p. 34).

Desse tempo ocorrido, resultou o que sou. Professor e investigador, inscrito na Educação Artística, num mundo que anda às avessas, habitando um território minado.

A certeza das fragilidades próprias esclarecem, para mim próprio, o logro em que cairia se aceitasse transformar os meus discursos em autoridade, os ostentasse nos palcos que se me oferecem para com eles me envaidecer, pretendendo com eles ensinar numa acção missionária.

Há uma procura em mim de discrição e de escuta, uma procura de suspensão permanente do poder que os lugares que ocupo me permitem exercer. Em vez de propagandear o que penso como verdade, prefiro procurar espaços partilhados e agonísticos de conhecimento, ouvindo, repensando o que sei, enfrentado as próprias fragilidades. Reconhecendo a necessidade de me descolonizar dos conceitos, que embora por vezes estranhos à minha consciência política, me constituem.

A maior riqueza

do homem

é sua incompletude.

Nesse ponto

sou abastado.

Palavras que me aceitam

como sou

— eu não aceito.

Não aguento ser apenas

um sujeito que abre

portas, que puxa

válvulas, que olha o

relógio, que compra pão

às 6 da tarde, que vai

lá fora, que aponta lápis,

que vê a uva etc. etc.

Perdoai. Mas eu

preciso ser Outros.

Eu penso

renovar o homem

usando borboletas.

Manoel de Barros

Retrato do artista quando coisa 
Estabeleço assim uma impossibilidade, a de no palco afirmativo do discurso, da exposição, da apresentação, evitar a vaidade que as palavras sempre transportam, esbater o poder que lhes é inerente e a imanência que as povoam. No entanto, sem querer diluir a imanência agonística das representações que vou construindo, da provocação dialogante promovida.

Preciso de ousar deslocar-me de mim, de procurar o que ainda é estranho ao que sou e, nessa nudez melhor me descolonizar, tentando entender de modo mais profundo e alargado o que me colonizou e o que me escapa, ouvindo esse Sul político, que pertence por direito ao mundo-comum, mas, a quem o Ocidente negou e nega a possibilidade de devir. Preciso de partilhar com os outros a minha incompletude e as minhas inquietações.

Tentando ser mais claro: sei que o sujeito que sou resulta dos modos como fui seduzido pelo aparato da sociedade onde vivo e pelo efeito dos seus dispositivos de controle; sei que minhas subjectividades resultaram também do enamoramento exercido pelos que me são próximos; resulto, evidentemente, do que as tecnologias de governo se sobrepuseram à minha atenção e me inundaram o ser. Esta identificação tem o acento que minha condição de branco-homem-europeu lhe acrescenta, no registo da prepotência invasora e omnipotente que lhe permitiu conferir a dimensão de uma soberba imperial imposta pelo regime capitalista em que temos de viver. Reconheço o quanto pertenço aos discursos hegemónicos que nesta civilização ocidental operam, que hoje legitimam um poder que pode, sem ser posto em causa, determinar mesmo quem pode e não pode viver (MBEMBE, 2016).

Por isso, preciso de entender as próprias inquietações, ouvir outras vozes, ler os ocultos e os pensamentos silenciados, pisar outro chão: sei que tenho de me deslocar de mim, se quero conquistar o equilíbrio e alguma lucidez.

... o conhecimento das mulheres, os saberes locais, os ligados à experiência material concreta, os saberes subalternos e alternativos, a experiência prática das práticas de vida quotidiana, os processos de cura ancestrais, várias terapias corporais ou espiritualidades, etc., saberes científicos antigos oriundos de diferentes culturas que viajaram anonimamente e de forma não situada. (IVEKOVIC, 2018, p. 127).

Este tempo em que vivo, de fracasso, despreza e oculta os crimes que foram, e são, cometidos, em particular nos outros-mundos, aos 'condenados da terra' (FANON, 2015). Preciso de saber o que antecedeu e construiu este tempo. Preciso de me inundar no político, encarar o anacronismo intempestivo do presente e entender o que é ser contemporâneo (AGAMBEN, 2010). Ao longo da história, nós, do civilizado mundo ocidental, colonizamos o que não nos pertence, destruímos sabedorias ancestrais, manuseamos a história impondo modos de desenvolvimento desfavoráveis para os povos que se libertaram dos regimes coloniais, alimentamos 
governantes que redobram de modo ignóbil o racismo e ampliam, em benefício próprio, a discriminação e a pobreza. Do que eram as realidades e as culturas desses outros-mundos, nada aprendemos, apenas os pilhámos, festejando o exotismo encontrado e os temperos especiais, enriquecendo com os seus recursos. Delapidámos a natureza, o que nos faz temer o amanhã, e nunca entendemos o Universo como um de-todos, dele apenas nos apoderámos, transformando os nossos conceitos nos reinantes. Instalando o desrespeito capitalista pela natureza e pelo ser, destruindo a unidade existente entre o humano e a terra. Nesse caminho construímos o nosso fracasso, anulamos o devir, conquistando o medo que nos tolhe o amanhã.

O colonialismo não é apenas o modo autocrático como tratamos os Outros, é também a prepotência e o altivismo que incorporamos em nós. Parte do fracasso a que assistimos ao enfrentar dos dilemas actuais, é alimentado pela natureza colonial que incorporamos, no modo como optamos pela singularidade, pelo interesse do um, em detrimento da escuta do outro, e do interesse pelo comum. A sedução de um apregoado viver-bem vai-nos envolvendo numa arrogância ignorante do que se passa para fora de nós, que nos cerca num medo atroz pelo que há-de vir, e nos tolhe o movimento. Ainda não entendemos que precisamos de nos deslocar de nós, de sair da casca, de olhar para o todo, se queremos dar possibilidade a um aberto e a um comum. Precisamos de repensar os objectos que alimentam a arquitectura epistemológica do nosso viver. Essa deslocação, inevitavelmente, terá de ser radical, terá de encarar a descolonidade. Terá de rever o que nunca quisemos ver no colonial que está em nós, na prepotência e arrogância do nosso 'saber', de entender a presença da matriz capitalista nos pilares que construíram a modernidade, o modo como povoa as nossas subjectividades.

$\cdots$

Os que permanecem e acenam, não sabem.

Paul Celan, Em Viagem, (1952)

Deste meu esforço de entendimento, resulta um conjunto de reflexões, apenas esboçadas, alojadas nos terrenos que frequento, do relacionamento com a arte, da interculturalidade, traduzidas para a acção/investigação em educação artística engajada na luta, enfrentando o capitalismo, o colonialismo, o patriarcado.

Encara-se aqui a educação artística como uma área de acção/investigação, que considera as práticas artísticas como um movimento permanente, que pode permitir, pela performance que comporta, pelo conhecimento que irradia, pelo que o fazer-artístico integra a construção da cultura de si, re-entender as concepções sociais acentuando as suas ambivalências, possibilitar encontrar um sentido para um comum.

Identifica-se que os elementos que deram substância à Educação Artística, deste local onde tenho os pés, são estabelecidos apenas nas geografias que configuraram o 
Ocidente. Uma educação artística ignorante das práticas artísticas endógenas, dos processos educativos ancestrais, do sentir e dos saberes que os de outros-mundos detinham e patenteiam, na sua resistência à dominação política e cultural a que foram submetidos.

Situar a Educação Artística nos limites de um espaço de descoberta da genialidade e da singularidade dos sujeitos, esquece modelos de relacionamento educativo que se misturam com a simplicidade do viver em comum, apenas acentua e naturaliza a exclusão como o resultado dos procedimentos racionalizados de obtenção, em cada um, das armas de um sucesso competidor.

Hoje a educação artística, para sair da rotina onde se encontra, precisando de um olhar-outro, que se desloque dos discursos de verdade fechados e Ocidentais, os questione numa arqueologia que revele o que sempre foi esquecido e oculto. Que valide diferentes modos de ver, de pensar, de agir e de ser. Que se envolva no mundo entendendo de que este tempo pode ser um tempo de transformação e da reconfiguração necessária. Para tal será preciso re-visitar os enunciados que alimentam os discursos de verdade, o seu sentido elitista que tornaram a prática educativa como reprodutora e colonial, questionar os modelos que se repetem, e repetem.

O mundo é diverso, e cada pedaço é, em si, um campo de complexidade. A cultura africana não é única mas uma rede multicultural em contínua construção. Os teóricos e analistas afligem-se com esta indefinição (COUTO, 2005). Entender o mundo-como-um-todo, nas diferenciações que o enriquecem, é o modo decente, ético e epistémico, de criar, num aberto, a possibilidade de um devir democrático e não discriminatório. Este esforço passa por um movimento de deslocalização das práticas coloniais, autoritárias e centralizadoras, para os territórios da solidariedade e de valorização do comum. Precisamos dessa prática nova na arte e na educação artística.

$\mathrm{Na}$ Europa, a arte desde bem cedo deslocou as relações com o comum para o terreno da exibição; da presença da genialidade do autor, para a montra da transcendência da obra; da ostentação de um estabelecido bom-gosto; para a exibição da condição burguesa de riqueza. A representação das subjectividades presentes nas encruzilhadas do tempo, tornou-se fechada dentro do 'campo da arte' para os que a frequentam e integram. Desobediente em muitos artistas, irreverente por vezes, insubmissa, desafiante de estereótipos, mas, em grande parte, absorvida pelos mecanismos de ocultação e de legitimação estabelecidos. As perturbações criadas rapidamente são anuladas, nesta sociedade, como nas escolas onde o que o aluno apresenta, só é aceite se 'integrado' no gosto reinante, se não perturbar o que-se-espera. ... o museu é um espaço de neutralização e de domesticação de forças que estavam vivas antes da sua museificação. (MBEMBE, 2016, p. 227).

Muitos artistas assumem atitudes de recusa do espectáculo que a visibilidade da arte atrai, escolhendo o campo da invisibilidade para a sua presença nesse palco, desestabilizando-o, preferindo intervenções mais corrosivas e radicais face ao dominante. Aceitaremos nós, nas escolas, na educação artística enfrentar essa dimensão dissonante, essa desobediência? 
O que nos é oculto, o que nos é apresentado como desprezível, ou de valor duvidoso não permite esclarecer que os discursos sobre arte que a civilização ocidental faz engrandecer, para se enobrecer, pretende inibir a capacidade de cada um, e de todos, impedir a cada um, a possibilidade de construção das suas enunciações.

O que é ocultado, o que é inibido e recusado, corresponde de uma estratégia de poder que constrói uma realidade e os rituais de verdade que governam o nosso presente.

O ensino artístico tem de evitar replicar o sistema de entendimento da arte que o neoliberalismo pretende como único. Outros campos de entendimento são pertinentes, onde artistas estabelecem com as comunidades e com as populações escolares modos colaborativos de se entender como a arte pode ser e como a educação artística se pode afastar do exercício das habilidades, da exploração da genialidade, do eu, da reprodução do já visto, do inócuo, da perseguição do já pensado, da procura de um tempo terapêutico produtor de instantes de felicidade. A arte tem de ser entendida nas escolas pela conflitualidade e ambivalência que transporta, vista como diversa, diferenciada, contraditória no modo como se entende as relações que estabelece. La cuestión real se refiere a las formas posibles del arte crítico, las diferentes formas como las práticas artísticas pueden contribuir a la impugnación de la hegemonia dominante. MOUFFE (2007: 67).

A arte teve sempre um estatuto de controvérsia com o real, foi isto e também aquilo, foi sempre um campo de legitimação do poder e também de inconstância, de reconfiguração dela própria e onde interferia. A arte pode sempre ser um pode-ser.

Perseguindo uma prática artística que apresente a sua imanência, sem se fechar na genialidade ou no sentido estético do seu autor, isolada em terrenos remotos onde apenas os 'entendidos' acedem.

El camino iniciado en el siglo XIX con el Romanticismo alemán, que afirmaba la primacía del artista sobre la obra, alcanzó sus últimas consecuencias en la elevación de aquél a "estrella" de una microsociedad internacional cuyos intereses eran esencialmente económicos. (PERNIOLA, 2016, p. 10).

Para mim, a questão está na necessidade que tenho de me deslocar das grandes verdades que alimentam este tempo em que vivo. Um olhar desconfiado sobre a dissolução do objeto de arte, no entanto, permite-me entender que essa dimensão desafiante, abre um espaço para as práticas educativas, onde se podem promover experiências que promovam aprendizagens abertas e a construção de consciências reflexivas, sem prisões à 'expressão', nem de amarras à imitação das formalidades que o modernismo introduziu, como as unidades curriculares ainda acentuam, do ponto, da linha, do plano, da textura,... 
La descolonización de la historia narrada y del pensamiento historiográfico imperial es parte de la tarea del pensamiento decolonial para avanzar en la opción decolonial junto a otros proyectos liberadores ya existentes. (MIGNOLO, 2009, p. 270).

A arte, numa entoação de voz frágil e de escrita em letra minúscula, pode instigar a um entendimento radical, em cada um de nós, do comum. Pode ser um plano para a sua transitoriedade, mas essa dimensão só tem sentido, digo-o, se se fundir a arte no político.

O que para aqui trago, pretende apresentar apenas a convicção pessoal de quem se inscreve na acção/investigação em educação artística, de que é preciso repensar os conceitos que o modernismo na arte ocidental trouxe, e a pós-modernidade confunde, enquanto instigadores sociais, mas também enquanto enunciados que alimentaram as estratégias hegemónicas, ou que por elas foram aprisionados e esclarecer o quanto eles não correspondem, hoje, às encruzilhadas sociais que o capitalismo e os interesses do capital financeiro dominam. Então, como acompanhar a deriva que a arte contemporânea comporta que amplia a sua distância com o que lhe é externo, que não colabora, com quem pode odiar o seu tempo, mas sabe em todo o caso que lhe pertence irrevogavelmente, sabe que não pode fugir ao seu tempo. (AGAMBEN, 2010, p. 20).

Claro que a educação artística pode ser um terreno estimulante e desafiador para as crianças e os jovens geradora de confiança no seu fazer, de disponibilidade para o desafio e para a diferença, de novos modos de sentir e de pensar. A relação que na educação artística pode ser estabelecida com o mundo pode acentuar em cada criança e em cada jovem o desenvolvimento do seu modo de lidar com o seu imaginário, com as representações de si e com as que lhes são presentes. O contacto com a arte pode, nesse sentido, estabelecer desafios de exploração das ideias e significados que cada um precisa para si, mas isso significa que é preciso desviar os modos usuais onde o contacto com as obras de arte e com os artistas propiciam apenas uma incorporação de modos de ver, de pensar e de agir, que não são gerados pelos sujeitos, mas resultado de um poder que sobre eles se exerce pelas circunstâncias escolares e culturais que se estabelecem. Yo creo que necesitamos recuperar un cierto sentido de la contextualización política de la autonomía artística y su transgresión, cierto sentido de la dialéctica histórica de la disciplinariedad crítica y su contestación, para intentar de nuevo proveer a la cultura de un margen de maniobra. (FOSTER, 2004, p. XIV).

Talvez não precise de referir, por tão evidente, como a avaliação aniquila a potência que o artístico comporta, de como nos comportamentos usuais, grelhando numa matriz de metas e objectivos, se centra a classificação no modo como a criança e o jovem se deixaram colonizar e, nessa pose escolarizada, como apresentam as respostas-certa, o lindo-trabalho, a encantadora prenda-para-os-pais. Avaliação onde, mes- 
mo as 'respostas pessoais' e o 'trabalho-livre', se condicionam a um olhar examinador externo e formatado e se estabelecem os critérios de exclusão e de discriminação.

Em qualquer cidade, há ricos e pobres. Estes dois grupos constituem por excelência os elementos, as partes da cidade, pois designam os seus únicos princípios não cumulativos. (...) Daí advém uma segunda determinação da arte política, que é, em termos modernos, a arte de lidar com o que existe: de lidar com os inconciliáveis, com essa co-presença dos ricos e dos pobres, que já não podem ser postos borda fora, que permanecem ligados ao centro da cidade. (RANCIÊRE, 2014).

$\mathrm{Na}$ linha do que escrevo, da necessidade de repensar o modo como transferimos para as escolas, para a educação artística, os conceitos estabelecidos desde a arte moderna, tem de se entender, que neste tempo contemporâneo que vivemos, na sua esquizofrenia, não podemos ficar confortáveis com o prolongar dos modos usuais de se criarem subjectividades, mas se deve assumir a permanência do transitório na construção dessas subjectividades pelos alunos, permitindo e fomentando, neles, o desenvolvimento de uma reflexividade emergente. A ideia da arte, como palco do indivíduo isolado, como espaço psicológico da pessoal salvação, bem como a educação artística como espaço de felicidade terapêutica, tem de dar espaço a uma consciência social de pertença ao mundo onde se interfere, onde se partilham os desafios comuns. Transforme-se o ser-só, narcísico, num ser-com, solidário. Criem-se espaços para a emergência de discursos sociais, para o colectivo, espaços de aprendizagem e exploração sobre si, construção da cultura de si, sobre o mundo-todo.

Apresento a necessidade urgente de errância, de se enfrentar o colonial que transportamos e o colonialismo que incorpora o capitalismo onde mergulhamos, $\mathrm{o}$ que consiste numa deslocação de nós. ... errante é o que não se conforma com um estado de coisas ou alguém para quem as coisas não têm estado fixo, mas que busca interromper e tornar impossível a continuidade do que está sendo ... (KOHAN, 2015, p. 60). Temos o dever ontológico de enfrentar o poder que também nós exercemos e o modo como aceitamos e prolongamos o ser que somos. Este dever ontológico, tem de comportar o entendimento de que o caminho usual de construção dos sujeitos através das aprendizagens do artístico (e muito pelos sistemas de avaliação existentes), resultam em processos excludentes. Até onde nos perturba, pergunto, deixar crianças e jovens incorporarem narrativas que lhes são coladas de insucesso e de pouca-capacidade, sem lhes ser permitido tornarem-se os autores da sua própria vida. Sejamos capazes de permitir a todos, sem distinções, a possibilidade de desembrulharem a potência que têm, inevitavelmente, em si. ... o conhecimento não é simplesmente a revelação de um segredo, nem a iluminação de algo obscuro, nem, enfim, a exposição de um conceito dado a priori, mas o estender, o deslindar, o exprimir algo que está embrulhado, envolto, recolhido. (PERNIOLA, 1990, p. 24) 
Saberemos nós, numa deslocação para fora da tradicionalidade que nos preenche, ser capazes de alguma insubmissão perante as estratégicas escolares existentes e sobre os aparatos administrativos e transformar a educação artística num terreno de acção crítica, onde os alunos possam ser desobedientes perante o estabelecido, construtores dos seus desejos, possam ser cúmplices dos seus comuns, sem isso lhe causar insucesso e exclusão? Entendermo-nos de modo diferenciado é mudar as práticas para novos enquadramentos, onde o gosto de obedecer seja pervertido.

A insatisfação é a capacidade de compreender que, para podermos aspirar à transformação ética e equitativa do mundo global em que vivemos, sistemática e incansavelmente teremos de "regressar" às condições sociais e históricas daqueles que se encontram no domínio da morte social - os excluídos, os marginalizados, os desprovidos.(BHABHA, 2007, p. 43).

Trazer para a educação artística as conflitualidades do contemporâneo e a atenção para o modo como as relações humanas se estabelecem, des-ocultar do Outro e do que há nele, não aceitar a exclusão, querer saber o que se passa no mundo-todo. Esse caminho afasta-se do estado de contemplação da arte, para a sua problematização, integra-nos no problema, integra os alunos no problema. Essa controvérsia gera a intranquilidade? Espero.

Quão grande e assustadora pode ser a dimensão dos excluídos, dos sem-emprego-e-sem-esperança, dos refugiados sem-espaço-e-sem-água, dos resíduos humanos sem-nome-e-sem-rosto, dos novos-remediados sem-futuro? No cenário que me é oferecido me interrogo. Como saber, no que me é apresentado e oferecido, o que é escondido, e o que de facto existe no que nos é mostrado?

Preciso meter as mãos, ou por os pés ao caminho. Preciso de proximidade, da discussão e da luta. Preciso de pensar, preciso que a investigação decorra da acção intercultural em que colectivamente me envolvo. Preciso do estímulo da arte e do artístico, da complexidade da educação artística, da interculturalidade.

A poesia, a arte, desarrumam para tentar arrumar por dentro; e pode haver muito sentido na desarrumação. Desarrumam para poderem depois entender e fazer algum sentido do mundo. Ana Luísa Amaral, Poeta

Desarrumo-me por dentro, e desarrumado me aproximo dos que pertencem ao mesmo comum. Os que de mim se aproximam, estudantes, investigadores, camaradas, cheiram esse desarrumo, a inquietação, a desorientação que irradio. Essa é a minha franqueza. Desloco-me, junto-me a lutas pela vida, na procura de uma epistemologia própria afastada da arquitectura cognitiva que instituiu o colonialismo, o capitalismo e o patriarcado.

Nesse terreno da acção/investigação, nesse espaço intercultural, me encontro. Procuro os campos de cor existentes, as irreverências, a lentidão 
Sabe, eu achava que era preta, que não ia ter amizade com ninguém... Eu tinha uma coisa comigo, eu tinha vergonha da cor, porque era preta ... muitas vezes, aconteceu de eu sentir assim na pele que as pessoas desfaziam da cor ... eu tinha medo, eu não era de fazer amizade de jeito nenhum, eu era igual a um bicho do mato. Então, eu conheci este pessoal, sabe eu senti que eles faziam muita conta de mim, eles davam muita atenção, então foi aonde eu passei a me sentir como gente. (Cida, Mulher, 'bóia-fria', negra). (SILVA, 1999, p. 273)

\section{REFERÊNCIAS BIBLIOGRÁFICAS}

AGAMBEN, G. Nudez. Lisboa: Relógio D'Água, 2010.

BHABHA, H. K. Ética e Estética do Globalismo: Uma Perspectiva Pós-Colonial. In: TRADUÇÃO DE CATARINA MIRA (Org.). A urgência da teoria. Lisboa: Edições Tinta-da-China e Fundação Calouste Gulbenkian, 2007.

CÉSAIRE, A. E os cães deixaram de ladrar. Lisboa: Diabril, 1975.

COUTO, M. Pensatempos. Lisboa: Editorial Caminho, 2005.

FANON, F. Os Condenados da Terra. Lisboa: Livraria Terra Livre, 2015.

FOSTER, H. Diseño y Delito. Madrid: Ediciones Akal, 2004.

FOUCAULT, M. O que é a crítica? seguido de A cultura de si. Lisboa: Edições Texto \& Grafia, 2017.

IVEKOVIC, R. A política da tradução de conceitos deslocados. Soberania, nação e subjetivação na Ásia emergente. In: SANCHES, M. R. (Org.). DESCOLONIZAÇÕES reler Amílcar Cabral, Césaire e Du Bois no Séc. XXI. Lisboa: Edições 70, 2018.
KOHAN, W. O. O mestre inventor. Relatos de um viajante educador. Belo Horizonte: Autêntica Editora, 2015.

MOUFFE, Chantal. Prácticas artísticas y democracia agonística. Universidade Autónoma de Barcelona, 2007.

MBEMBE, A. Políticas da Inimizade. Lisboa: Antígona Editores Refratários, 2016.

MIGNOLO, W. La idea de América Latina (la derecha, la izquierda y la opción decolonial). CRÎTICA Y EMANCIPACIÓN Revista latinoamericana de ciencias sociales - Año I No2, 2009. p. 251-276.

PERNIOLA, M. Enigmas: egípcio, barroco e neo-barroco na sociedade e na arte. Chapecó - SC, Brasil: Editora Argos, 1990.

_._._. El arte expandido. Casimiro Libros.

RANCIÈRE, J. Nas Margens do Político [Aux Bords du politique]. Lisboa: KKYM, 2014.

SILVA, M. A. De M. (1999). Errantes do fim do século. São Paulo: Fundação Editora da UNESP, 1999. 


\section{Madalena Zaccara}

\section{APRENDER A OLHAR NOVAMENTE: MULHERES ARTISTAS BRASILEIRAS NA "ÉCOLE DE PARIS"}

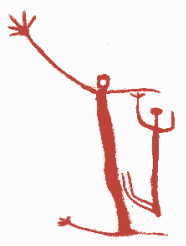

Um ensino/aprendizagem decolonial encontra suas raízes nos projetos insurgentes que resistem, questionam e buscam mudar padrões coloniais do ser, do saber e do poder. O colonialismo é mais do que uma imposição política, militar, jurídica ou administrativa. Sob a forma de colonialidade, ele chega às raízes mais profundas de um povo e sobrevive apesar da sua emancipação política. A colonialidade é antes de tudo um padrão de poder. Trata-se de uma forma de manutenção do domínio de um conhecimento sobre outro; de uma cultura sobre outra; de um gênero sobre outro; de um corpo sobre o outro. Ela transcende os limites da colonização imposta pelas armas e se perpetua como forma de imposição cultural, operando de forma objetiva em algumas culturas e subjetivas em outras. ${ }^{1}$

Pensar gênero e decolonização através da Arte/Educação passa pela produção de novos conteúdos, de uma nova epistemologia que envolva uma história da arte para além daquela que aprendemos e ensinamos (hegemônica, masculina e branca) na qual o papel da mulher artista é a expressão de sua condição: submissão. Novos olhares chegarão, dessa forma, à sala de aula e, enquanto professores, através de um método comparativo, poderemos nos inspirar e embasar neles para estabelecer paralelismos entre as versões "oficiais" da história da arte e aquelas obtidas por investigadoras feministas.

\footnotetext{
${ }^{1}$ Nas palavras de Quijano ela "sustenta-se na imposição de uma classificação racial/étnica da população do mundo como pedra angular do referido padrão de poder e opera em cada um dos planos, meios e dimensões, materiais e subjetivos, da existência social quotidiana (...)"in Aníbal Quijano. Colonialidade do Poder e Classificação Social in Boaventura de Sousa Santos; Maria Paula Meneses (Org.) Epistemologias do Sul. Coimbra: Edições ALMEDINA. AS.2009. p.5
} 
Sabemos que o olhar, masculino, sempre ditou as regras quer ele fosse o do historiador, do crítico ou do professor. A pesquisa, sob um olhar decolonial, aplicada à sala de aula funciona como uma estratégia de subversão visando provocar reflexões sobre a naturalização da dominação masculina e buscar romper com ela. A arte/educação é em si um veículo político e o pesquisador(a) poderá trazer novos horizontes disponibilizando caminhos, para uma ação transformadora.

O objetivo de nosso texto é expor algumas considerações sobre uma pesquisa que desenvolvemos, em um período de um ano de estudos em Paris, junto a Université Sorbonne e subsidiada pela CAPES, sobre a presença da mulher artista brasileira no período conhecido na História da Arte como "École de Paris"(1900-1939) com a tutoria do sociólogo Michel Maffesoli. Nela, levamos em conta que pensar uma arte/educação decolonial não implica em deslegitimar conhecimentos em arte em uma perspectiva europeia (diferente de uma visão eurocêntrica), mas abrir espaço para legitimar novos saberes vistos de outros ângulos geográficos e sociais. Afinal, cabe a nós, mulheres, regatar a nossa própria história.

\section{A ESCOLA QUE NÃO ERA ESCOLA: A “ÉCOLE DE PARIS”}

A invenção do termo "École de Paris"2 é atribuída ao crítico de arte André Warnod. ${ }^{3}$ Os participantes dessa "escola", que acorriam a capital francesa em busca de maior liberdade de expressão e não se preocupavam com uma unidade de linguagem ou com uma harmonia política, mas com a vontade de criar e buscar uma expressão pessoal. A "École de Paris" também pode ser definida como um campo de batalha para a criação de um discurso alimentado por esperanças, dúvidas, certezas, rejeições e consagrações, mas que foi, indiscutivelmente, um fenômeno que fez de Paris o local de encontro de artistas de todo o mundo. A "École" não pode ser definida como uma escola no sentido usual do termo, mas como um espaço de trocas e produção feito de miséria e de sonhos de fortuna, de sucessos e de anonimatos, de boemia e de negociatas.

Marchands e jornalistas, artistas e boêmios se cruzavam entre Montmartre, Montparnasse e nos arredores das Beaux-Arts. Foi, portanto, nesse universo de múltiplas ideias e linguagens que se encontraram artistas de todo o mundo, inclusive brasileiros. Estes, provenientes de espaços sociais diversos, estavam atrelados a determinados fatores condicionantes: uma menor liberdade de horizontes para quem estava comprometido com as subvenções estatais e um maior espaço criativo,

\footnotetext{
2 "Escola de Paris" é um termo que se refere à comunidade de artistas franceses e estrangeiros que trabalharam em Paris durante a primeira metade do século XX. Não tem a ver com um estilo, escola ou movimento estritamente definido. Trata-se na realidade do reconhecimento de Paris como centro do mundo da arte do início do século XX até a Segunda Guerra Mundial
}

${ }^{3}$ WARNOD, André. Les berceaux de la jeune peinture :l'École de Paris. Paris Albin Michel, 1925. 
expositivo, crítico e receptivo para aqueles que detinham um maior poder financeiro e, consequentemente, um maior capital social.

Hermingway nos convida a viver um pouco do dia a dia daquela cidade de contrastes que podia se apresentar limpa e hospitaleira ou triste suja e agressiva, mas, objeto do desejo de todos aqueles que podiam lá estar, naquele momento. Ele nos fala do bem-estar dos cafés, dos encontros, mas também da pobreza e do frio para os convidados da festa mais pobres, quase miseráveis.

Toute la tristesse de la ville se révélait soudain, avec les premières pluies froides de l'hiver, et les toits des hauts immeubles blancs disparaissaient aux yeux des passants et il n'y avait plus que l'opacité humide de la nuit et les portes fermées des petites boutiques, celles de l'herboriste, du papetier et du marchand de journaux, la porte de la sage-femme - de deuxième classe - et celle de l'hôtel où était mort Verlaine et où j'avais une chambre, au dernier étage, pour y travailler ${ }^{4}$

Esse momento, que se propunha revolucionário, ainda era majoritariamente masculino. Mas, as mulheres artistas também nele circularam, mesmo que de forma mais marginal. A cidade oferecia a mulher em geral (e a artista em particular) um campo de acesso limitado aos espaços públicos e privados pois "las mujeres no podían habitar las esferas públicas por su cuenta, sin poner en riesgo su rango social y su reputación" ${ }^{5}$ e, apesar da liberdade revolucionária pregada pelas vanguardas, além da pouca mobilidade elas não eram aceitas como iguais no meio artístico. É necessário levar em conta que as mulheres artistas haviam conseguido entrar recentemente para a academia (anteriormente inacessível) e quando enfim isso aconteceu a ambicionada instituição já não detinha a importância anterior e era contestada pelas novas linguagens.

Toda essa conjuntura se aplicou em relação às artistas brasileiras que trabalharam naquele momento em Paris. Algumas se inseriram mais do que as outras nas linguagens e nos espaços da modernidade parisiense, na maioria das vezes contando com o apoio masculino para uma inserção nos grupos de artistas modernos; outras se mantiveram nos limites acadêmicos, mas, mesmo no trabalho destas últi-

${ }^{4}$ HERMINGWAY, Ernest. Paris est une fête. Paris: Éditions Gallimard, 1964 p.7.

\footnotetext{
${ }^{5}$ Hammergren, L. (1996). The Re-turn of the Flâneuse. Corporealities: Dancing knowledge, culture and power. En S. Leigh (Ed.), Corporealities. Dancing knowledge, culture and power, (pp. 54-71). New York: Routledge apud ALONZO-SANS, Amparo. Una profesora Flâneuse en París. Cartografías en la formación inicial de docentes in Arte, Individuo y Sociedad. Ediciones Complutense. 2019. P. 365. ISSN: 1131-5598.
} 
mas, o espírito do tempo se manifestou nos temas por elas tratados e nas primeiras ousadias de "flaneuses" em um espaço público monopolizado pelos homens.

\section{PARA NÃO SEREM ESQUECIDAS: ARTISTAS MULHERES BRASILEIRAS NA “ÉCOLE DE PARIS”.}

Que as mulheres artistas tiveram um tratamento diferenciado quer no acesso à formação, no reconhecimento de seu trabalho ou na preservação de sua memória já é quase consenso para aqueles(as) que trabalham com uma história (e um ensino da arte) conjugada no feminino. As artistas brasileiras não foram exceção e muito poucas, dentre aquelas que foram a Paris naquele contexto restaram nos manuais de história da arte brasileira. Elas foram excluídas pela pouca legitimação enquanto mulheres e metecas na capital francesa; por não terem desenvolvido (em sua maioria) uma linguagem dita "de vanguarda" ou seja: atrelada a colonialidade estética europeia e por não receberem no retorno ao país de origem o mesmo tratamento por parte da crítica e do mercado que seus colegas masculinos.

No Brasil a ideia dominante, naquele início de século, era a de que a arte para as mulheres nada mais era do que um passatempo, uma prenda a mais para as moças de famílias abastadas, consolidando uma formação voltada principalmente para o casamento. Aquelas que tiveram acesso a uma formação sistematizada faziam parte de uma elite burguesa e, mesmo, as que puderam e ousaram ir estudar na Europa, entraram tardiamente para uma formação sistematizada acadêmica, quando já aconteciam os movimentos de vanguarda e suas rupturas estéticas. Mais uma vez elas ficaram de fora ou tiveram que lutar, armadas bem fragilmente, na batalha por participação e reconhecimento por seus pares.

Para levantarmos e explicarmos a presença pouco marcante de nomes brasileiros femininos durante o período foi necessário investigarmos o fato interdisciplinarmente buscando apoio na história, sociologia e na própria história da arte ocidental considerando aqueles que a construíram, escreveram e que, portanto, processaram a não inclusão feminina.

Ao longo da pesquisa levantamos 41 artistas mulheres brasileiras presentes naquele momento da história da arte investigando arquivos de espaços de legitimação, a saber: academias, espaços expositivos, crítica e mercado. Pesquisamos mulheres artistas brasileiras que frequentaram a École des Beaux-Arts, a Académie Suisse que mais tarde trocará seu nome pelo de Académie Colarossi, a Académie Julian, a Académie de la Grande-Chaumière e a Académie Ranson. Os "Salões", locais de exposição que se tornaram verdadeiros acontecimentos formando reputações foram

${ }^{6}$ O termo "flâneuse" utilizado por Amy Levy em 1888 não aparece na maioria dos dicionários franceses. Ler ALONZO-SANS, Amparo. Op. Cit. p. 367 
também objeto de nossa pesquisa. Investigamos catálogos do "Salon de la Société Nationale des Beaux-Arts"; o "Salon des Artistes Français" que acontece até os dias que correm; o "Salon des Indépendants", "O Salon d'Automne" e o "Salon des Tuileries". Também pesquisamos o "Salon de la Societé des artistes decorateurs", o "Salon de L'Union des Femmes Peintres et Sculpteurs", o «Salon des Surindépendants » e o « Salon des Vrais Independantes » além de registros de exposições de marchands e de galerias de arte.

O texto, os escritos sobre arte incluindo a crítica da época, se constituíram em outra fonte inestimável para a nossa pesquisa. Eles nos serviram como veículos de informação, interpretação e avaliação daquele momento principalmente em relação às poucas mulheres artistas brasileiras ali contempladas. Também investigamos a contribuição das mulheres para a produção do discurso crítico no campo das artes. Marie Bashkirtseff, no final do século XIX, nos dá uma ideia das dificuldades encontradas:

On nous demande avec une indulgente ironie combien il y a eu de grandes artistes femmes. Eh! messieurs, il y en a eu et c'est étonnant, vu les difficultés énormes qu'elles rencontrent.Parlez donc aux gens comme il faut d'envoyer leurs filles dessiner d'après le nu, sans lequel il n'y a pas d'études possibles ${ }^{7}$

Em relação ao universo feminino que se constituiu no nosso objetivo de estudo traçamos um perfil individual que por questões de espaço não exporemos aqui. No conjunto da memória recuperada algumas poucas artistas se mostraram ainda notórias, mesmo após algum tempo de esquecimento. Outras foram objeto de atenção posterior de raras historiadoras de arte. Da maioria sequer havíamos lido seus nomes.

De algumas restaram apenas vagas indicações (sobrenomes que mudaram por um casamento posterior), algumas exposições, registros de matrícula... Enfim: rastros daquelas que lá atuaram no período em questão. De outras conseguimos situar vida e obra. Umas eram nobres, outras bolsistas, poucas das regiões não hegemônicas brasileiras, a maioria nativa do Sudeste. No que diz respeito à linguagem, ao estilo, umas poucas se inseriram nas linguagens vanguardistas, a maioria em uma fase de transição entre a academia e a vanguarda.

Obedecendo a um critério de ordem alfabética colocamos aqui os nomes das artistas resgatadas em nossa pesquisa: Adriana Janacopulos, Amélia Sabino de Oliveira, Anna Bayeux (Nicota Bayeux); Anita Malfatti, Angelina Agostini, Clotilde de Rio Branco, Cristina Capper Alves de Souza, Dinorah Carolina de Azevedo, Edite Maria Pinheiro de Aguiar Thiel, Emilie de Labourdonnay, Fedora do Rego Monteiro, Georgina de Albuquerque, Haydea Santiago, Helena Level, Helena Pereira

${ }^{7}$ ORELL, Pauline. «Les femmes artistes » in La Citoyenne $\mathrm{N}^{\circ} 4$ du 6 mars 1881 
da Silva, Hilda Campofiorito, Hortense Hamoir de Rio Branco, Isolina Machado Fanzeres, Josefina de Vasconcelos, Julieta de França, Julie de la Bourdonnay G. Roque Sistello, Laura Maia, Lucy Dora Ferreira, Luísa Brabo de Andrade, Mme. Castillo, Maria do Céu de Azevedo e Melo, Maria Agnelle Forneiro, Maria Barbosa de Oliveira e Silva, Maria Martins, Margarida Lopes de Almeida, Margarita Couymari, Marietta Rezende, Nair de Tefé, Mlle Negrão, Nicolina Vaz de Assis, Noêmia Mourão, Olga Mary Pedrosa, Regina Veiga, Tarsila do Amaral , Ursulina Pereira de Lyra, Valeria Teltscher.

Delas fizemos um perfil com as principais informações sobre vida e obra, a saber: biografia, descrição do trabalho, principais exposições individuais e coletivas, uma fortuna crítica e uma imagem. A proposta é que o material colhido seja utilizado em sala de aula complementando a bibliografia oficial rara sobre vida e produção de artistas brasileiras.

\section{UM ESTUDO DE CASO: HELENA PEREIRA DA SILVA}

Finalizaremos com uma incursão breve sobre uma das artistas pesquisadas. Pouco conhecida Helena Pereira da Silva era (para não fugir à regra da presença masculina como suporte) filha do pintor Oscar Pereira da Silva e de Julie Pereira da Silva, uma francesa de Bordeaux. Em 1910 ela expôs seus trabalhos no atelier do mecenas Freitas Valle que, então, julgou-a merecedora de uma bolsa de estudos para estudar em Paris. 8 Segundo a artista uma bolsa de apenas trezentos francos, quantia módica que não dava, também segundo ela, sequer para pagar um teto na capital francesa para onde ela partiu em março de 1911. Helena começou com aulas na Academie Julian naquele mesmo ano. Inclusive as de modelo vivo. Em paralelo, continuou a receber os ensinamentos de seu pai. Voltaram ao Brasil naquele, ainda em 1911, com a morte de sua mãe.

Freitas Valle novamente convenceu seu pai sobre a necessidade de Helena continuar seus estudos em Paris e em 1912 ela retornou. Mais independente, passou a frequentar novamente a Academie Julian onde voltou a trabalhar com modelos vivos masculinos e femininos. Depois, se transferiu para a Academie Colarossi onde frequentou uma turma mista. Dessas experiências ela remarca suas dificuldades principalmente em relação ao estudo do modelo nu: "Comecei o modelo vivo pela primeira vez na Academia Julien des Passages des Panoramas; quando vi o modelo nu, muito me intimidei". Como ela trabalhava sobre outros assuntos, acreditamos que tenha sido a nudez do modelo o motivo desse medo relatado. Não era fácil para uma mulher jovem enfrentar os limites impostos ao corpo e as regras sociais, mes-

${ }^{8}$ Helena Pereira da Silva Ohashi. "Minha vida. Brasil - Paris - Japão". São Paulo 1969 in ABRADEMI

- Asbiya City Museum of Art \& History, julho de 2004. 
mo na Paris dos anos loucos. Com cinco anos morando na cidade, porém, o olhar da artista muda e ela se queixa dos resultados de um convite para expor em Recife onde além de não vender nenhum trabalho definiu a posição da mulher daquela cidade como muito atrasada pois : "as moças só saíam acompanhadas de família, as mulheres que se aventuravam sós eram mal vistas". Após a experiência nordestina ela embarcou novamente para Paris onde estudou uns meses com o professor Biloul que ensinava na Escola de Belas Artes de Paris e que tinha aberto também um atelier. Em paralelo voltou a estudar na Academie de la Grande Chaumière.

Em março de 1929, enfim, foi aceita para o Salon des Artistes Français que ela considerava de difícil acesso e para o qual só enviou trabalhos incentivada por uma amiga, também artista, Yvone Carro. Helena pensava que não seria aceita pois os professores "moravam em Neuilly, Passy, Etoile, ficavam bem longe do bairro pobre e petit bourgeois onde morávamos." Quando ela recebeu o aceite do Salão "chorava de alegria e emoção"10

Seu relato destaca situações vividas por várias mulheres artistas brasileiras em Paris. Principalmente pelas bolsistas. Enquanto Helena não acreditava ser aceita no Salon des Artistes Français, em 1929, amedrontada pelo status social do júri em relação a uma moça pobre que morava em um bairro obscuro, sua colega Tarsila, milionária e bela, já expunha, em 1926, com todo o apoio da mídia, paraninfada por Cendrars na Galerie Percier. Ao mesmo tempo em que ela confeccionava seus próprios vestidos para economizar enquanto chefe da casa (sobrevivendo com uma parca pensão com duas irmãs), Tarsila, vestia-se com Paul Poiret e recebia "tout Paris" em seu ateliê. Eram duas artistas brasileiras. Eram dois universos paralelos. Essas situações diversas refletiram também na preservação da memória naquele momento.

Em 1930, Helena voltou a Paris e, em 1933, casou-se com Riokai Onashi partindo para o Japão, na terceira classe do Kashima Maru. Em 1943 o marido de Helena faleceu. Em plena Segunda Guerra Mundial. Helena voltou ao Brasil quando acabou a guerra. Segundo suas palavras ela tornou-se então, para os vizinhos, "uma mulher de idade indefinida, alta, magra, viúva, de óculos escuros, que mora só com seu gato”."11

\footnotetext{
${ }^{9}$ Helena Pereira da Silva Ohashi MINHA VIDA Brasil - Paris - Japão. Op. Cit 1969/2004

${ }^{10}$ Idem

${ }^{11}$ Ibidem
} 


\section{FONTES PRIMÁRIAS}

Archives Nationales. Pierrefitte-sur-Seine. França.

Archives da Bibliotheque Kandinsky. Centre Pompidou. Paris.

Archives du Grand Palais. Paris.
Bibliothèque Nationale de France - Paris Archives Geo Charles. Musée Geo Charles

\section{FONTES SECUNDÁRIAS}

ALONZO-SANS, Amparo. Una professora Flâneuse en París. Cartografías en la formación inicial de docentes in Arte, Individuo y Sociedad. Ediciones Complutense. 2019.

BOAVENTURA de Sousa Santos; MENESES, Maria Paula (Org.) Epistemologias do Sul. Coimbra: Edições ALMEDINA.2009.

HERMINGWAY, Ernest. Paris est une fête. Paris: Éditions Gallimard, 1964.

ORELL, Pauline. « Les femmes artistes " in La Citoyenne $N^{\circ} 4$ du 6 mars 1881

PEREIRA DA SILVA, Helena Ohashi. "Minha vida. Brasil - Paris - Japão. São Paulo 1969" in ABRADEMI - Ashiya City Museum of Art \& History, julho de 2004. http://www.abrademi.com/index.php/ helena-pereira-da-silva-ohashi/
WARNOD, André. Les berceaux de la jeunepeinture :l'École de Paris. Paris Albin Michel, 1925

ZACCARA, Madalena. Mulheres artistas brasileiras na É cole de Paris: entre a academia e as vanguardas (no prelo) De Sinhá prendada a artista visual. Os caminhos da mulber artista em Pernambuco. Recife: CEPE. FUNCULTURA, 2017. 


\section{Rita Rainho}

\section{A INSURGÊNCIA DE UMA PLANTAÇÃO DE ALGODOEIRO HOJE: DOS TEMPOS DE MAGIA ESCRAVA À RESISTÊNCIA CULTURAL PÓS INDEPENDÊNCIA EM CABO VERDE}

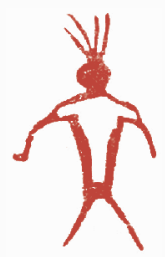

PORQUÊ O ALGODÃO?

Tudo começou às voltas com a organização de um projeto para apresentar, conjuntamente com Vanessa Monteiro, no Salão de Design Created_in Cabo Verde (2018). Este Salão tinha como tema "O padrão da panaria cabo-verdiana como matéria criativa”, organizado pelo CNAD - Centro Nacional de Arte, Artesanato e Design, no Mindelo, ilha de São Vicente, em Cabo Verde.

De agosto a novembro desse ano realizamos uma pesquisa sobre a panaria cabo-verdiana recorrendo a livros, ao espólio do CNAD, e ao mestre artesão Marcelino dos Santos, o último ainda vivo na região norte de Cabo Verde com esse conhecimento, desde o ciclo completo da transformação da fibra do algodão a todo o engenho ligado à panaria, a construção do tear, a montagem da urdidura, o desenho e a tecelagem.

... pertence à natureza da sombra a característica de desaparecer logo que é atingida por essa luz intensa; nisso reside a sua diferença em relação à canonização institucional e à transmissão mediática. (PERNIOLA, 2006, p. 10) 
O que fazia ainda sentido criar no mundo contemporâneo? Essa era, e será, nossa pergunta. Atuando junto do sector das artes nas ilhas, nenhum objeto parecia fazer sentido para o Salão de Design, nenhuma obra parecia deixar a sombra que pretendíamos que se jogasse sobre as possibilidades que estavam por vir na relação com a herança da panaria.

A panaria cabo-verdiana, nas ilhas de Cabo Verde conhecida por panu di terra ou pano d'terra ${ }^{1}$, é uma técnica de tecelagem artesanal, em que os panos são conformados por bandas de menos de um palmo de largura, tecidas separadamente e cosidas no fim, ourela contra ourela. Em Cabo Verde existem três tipos de panos, Pano d'obra, Pano Bitcho, Pano Tchã, e foi no primeiro que nos concentramos.

O Pano d'obra caracteriza-se pelo preenchimento total de padrões, seguindo a estrutura de base, boca de pano, zona de transição e o corpo.

Nos padrões dos panos, pelo conhecimento do mestre artesão Marcelinos dos Santos, destacam-se a figura estilizada do Algodão, Cintinari e Roda Espora.

Foi aqui que tudo começou. Fixamo-nos na figura estilizada inicialmente, até que percebemos que o projeto só teria sentido numa visão holística. O regresso ao que teria originado a estilização da cápsula de onde brota a fibra do algodão nos padrões de panaria cabo-verdiana, foi o que nos permitiu sair do plano da criação autoral, do objeto de design, para o início de um entendimento partilhado sobre o passado e das heranças esquecidas, mas também de experimentação agrícola, educativa e artística que provocasse a possibilidade de futuro do algodão insular. $\mathrm{E}$ foi aí que nasceu o projeto "Neve Insular". Mas, antes de chegar a ele em concreto, faz sentido, entender a carga do território e da história do algodão que, consigo, inevitavelmente carrega.

\section{CONSUMO MÁGICO DO PANOD'TERRA NO TRÁFICO DO ATLÂNTICO COLONIAL}

Cabo Verde é um pequeno arquipélago situado no médio oceano Atlântico, a cerca de $600 \mathrm{~km}$ da costa ocidental senegalesa, na região Sahel e por isso marcada pela aridez de um clima tropical seco. Foi considerado desabitado quando os portugueses aqui atracaram em 1460, porém as ilhas já eram conhecidas pelos geógrafos árabes desde o séc. XI (VEIGA, 1997), e considera-se que fosse habitada por grupos de naufragados, provenientes de etnias wolof, lebus e felupes.

É a partir do séc. XV que se constitui colónia portuguesa, sendo que a fixação humana no território foi difícil e prolongada devido à aridez e escassez de recursos naturais, aspetos que até hoje determinam as condições de vida das populações.

${ }^{1}$ Foi de meados dos séc. XVI até XVIII uma moeda de troca no comércio da costa africana, com relevância no trânsito comercial e cultural entre as ilhas e o continente. As versões são de acordo com crioulo de Santiago e São Vicente. 


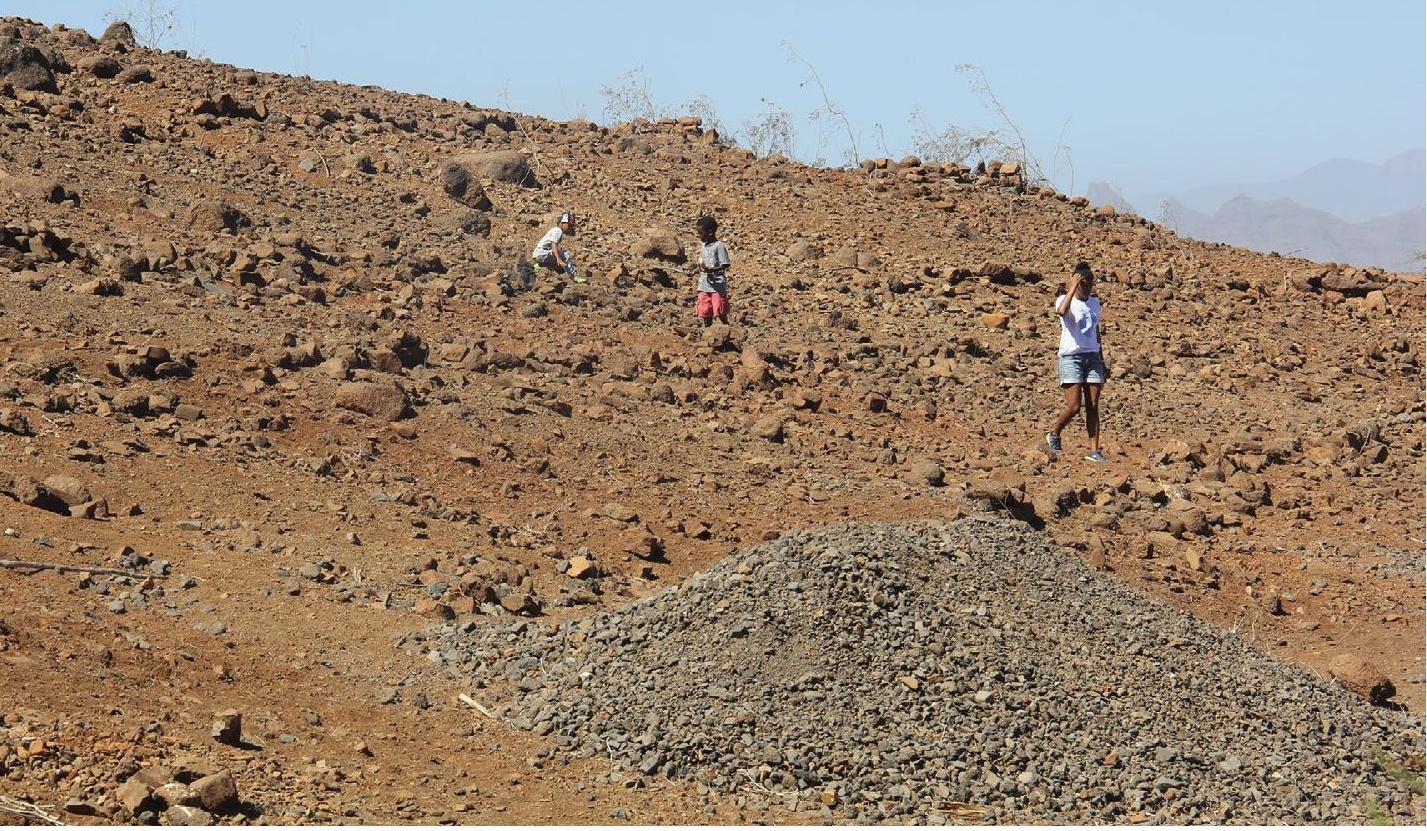

Madeiral, paisagem envolvente da plantação biodiversa, Neve Insular, 2019. 
A ilha de São Vicente, onde nasceu o projecto "Neve Insular”, foi a última a consolidar o povoamento, já no séc. XIX.

Antes da constituição da colónia portuguesa em Cabo Verde, em África já se cultivava o algodoeiro, utilizava-se o tear manual e fabricavam-se artesanalmente tecidos de algodão.

Em Cabo Verde, o cultivo do algodoeiro foi assumido logo no princípio da ocupação das ilhas, sobretudo nas Ilhas de Santiago e do Fogo, e a fibra era utilizada apenas para exportação com destino sobretudo a Portugal, Flandres, Espanha, mas também para os resgates na costa africana (CARREIRA, 1968).

A decisão política tomada por D. Afonso V, em 1466, de premiar com privilégios os europeus que residissem na ilha e, em 1472, de coagir os mesmos a povoarem o hinterlande produzirem mercadorias, em particular algodão, para o resgate na Costa da Guiné, fundou no arquipélago de Cabo Verde a primeira sociedade escravocrata da era Moderna e do Atlântico.(CABRAL, 2013, p. 35)

Estes regimes de plantação, no caso do algodão, deviam servir de íman para povoadores com ânsia de poder e riqueza, e noutro nível, deviam substituir a natureza preexistente, de paisagens antigas que era preciso remodelar, ou de formações vegetais anteriores que era preciso destruir, e o do regime de um ecossistema que era preciso substituir pelo agro-sistema (JOHNSON, 2013).

Em Cabo Verde, a produção de algodoeiro de sequeiro e de regadio, alcançou um valor acrescido, servindo para pagamento de impostos e outros serviços (nomeadamente as dízimas), assim como o aluguer e compra de casas.

A partir dos meados do séc. XVI até ao final do séc. XIX, regista-se um trânsito do 'ciclo do algodão' para o 'ciclo da panaria' (CARREIRA, 1968).

(...) preponderância dos "panos e roupas de Santiago» nos tratos e resgates na "Costa», a ponto de o "pano» haver conquistado posição privilegiada de «moeda-corrente» num sector (do Senegal à Serra Leoa, ou seja a «Costa da Guiné»), sendo procurado e preferido pelos estrangeiros, porque sem ele dificilmente conseguiam escravos e géneros ricos de produção africana: ouro, âmbar, cera, marfim, couro e outros; (CARREIRA, 1968, p. 157/158)

A valorização da panaria cabo-verdiana, através da singularidade dos panos d'terra ganhou um alto relevo económico e simbólico enquanto produto de consumo mágico no tráfico de escravos do Atlântico. 
A pedra do toque do dispositivo alucinatório do potentado é a ideia de que não há qualquer limite para a riqueza e para a propriedade e, portanto, para o desejo. É esta ideia de um imaginário sem simbólica que constitui o "pequeno segredo" da colónia e que explica a força imaterial do potentado colonial. (MBEMBE, 2014, pp. 198-199)

Mecanismos históricos conduziram a enormes atrocidades, atropelando recursos humanos e naturais e viciando o corpo humano de uma ganância insaciável composto naquilo a que entendemos por domínio colonial, e do qual o território de Cabo Verde foi também palco. A sede de enriquecimento associada a vastas invenções, fizeram das viagens, motivos de proclamação de descoberta, e/ou desejo de domínio e conquista predadora sobretudo dos continentes América e África. Domínio e conquistas que foram executadas pela força de poder, e pela ambição do capital em exponente.

Cabo Verde surge aqui como entreposto, funcionando como placa giratória comercial de tráfico atlântico inicialmente nos regimes de plantação e depois na escravatura; consolidando-se durante vários séculos um triângulo de exploração de comércio entre os continentes Europa, África e América.

É conhecido que o colonialismo atingiu o seu apogeu não tanto com a exploração de africanos submissos, mas com a transformação destes em objetos de uma economia imperial marcada pela sede insaciável de poder e riqueza. É curioso entender que esta sede de riqueza do colono introduz uma nova ordem de mercadorias, no caso a humana, autorizada pelos locais porque mobilizados pela necessidade e pelos fluxos do desejo (MBEMBE, 2014).

Através desta nova ordem, uma complexa máquina de consumo de pessoas, cujo poder e desejo, alimentou e engrandeceu o domínio europeu sobre os outros povos, promovendo o terror. Nestas relações intercontinentais vingou a corrupção e simultaneamente o encanto dos africanos pelas mercadorias europeias, sem valor económico, mas investidas no culto dos feitiços, numa espécie de novo lugar de deslumbramento e alucinação com o espelho exótico europeu. Em troca deste consumo de desejo e poder, de África se exportaram milhões de pessoas vigorosas, outras morreram nas guerras, nas viagens e por doença, e em África se travaram guerras entre locais e com colonos, destruindo-se reinos, culturas, aldeias e cultivos, em que poucas pessoas terão escapado aos agressores, mas nem sempre à fome e à morte.

Com a transformação de pessoas em mercadoria, e os regimes de plantação e exploração de recursos naturais, a Europa acumulou nesse momento valiosas riquezas roubadas com o extermínio dos ameríndios e com a exportação e o trabalho dos negros em escravatura sobretudo na América. Outras partes do mundo terão sido pilhadas e colonizadas, como a Ásia, e foi toda essa usurpação que construiu um capital, condições para os desenvolvimentos científicos e técnicos europeus. 
Aquilo que Mbembe (2014) ressalta é que a questão da raça serviu, ao longo dos séculos (com ênfase no regime de exploração nas plantações e no regime colonial), como exercício de poder, ordem social e aumento de rendibilidade económica. E, nesta economia de deslumbramento, balizada entre a vida, a morte e a abundância, consolidou-se durante séculos a circulação de produtos materiais e de capacidade simbólica em troca de outros bens, mas também em troca de pessoas. Entre esses objetos o pano d'terra.

Interessa entender a colonização na óptica de uma máquina produtora de desejos e de desvarios para entender o lugar do pano d' terra no tráfico atlântico, no quadro da cobiça dos colonizados que crescia com a raridade do mesmo pela possibilidade de distinção de estatuto, hierarquia, classe (MBEMBE, 2014).

No séc XVIII, a cultura de algodão e dos panos entraram em decadência. Ao nível do comércio de escravos, responsáveis pelas principais atividades da produção, fiação e tecelagem, regista-se uma afirmação do monopólio de escravos por parte da Coroa Portuguesa, vendidos ao dobro do preço, bem como o direito exclusivo da venda dos "panos de terra" (CARREIRA, 1968). Com a falta de mão de obra, os severos períodos de seca e fomes que a história registou no arquipélago a cultura de algodão caiu, acompanhada da produção em série de fios e tecidos que a Revolução Industrial permitiu.

Com a riqueza acumulada pelos impérios, as invenções começaram a proliferar na Europa. Entre 1766 e 1770, na Grã Bretanha, James Hargreaves desenvolveu a spinning jenny que permitia a um operário fiar 8 fios ao mesmo tempo, antecipando a própria máquina a vapor em 1776 e determinando o progresso da economia mundial. O início da Revolução Industrial veio criar a oportunidade de as sedes dos impérios coloniais exercerem o seu poder global, não através da força, mas do comércio. (ANDERSON, 2012, p. 45).

Ao mesmo tempo que se inicia a época que mais irá determinar interferências ambientais desastrosas, mudanças sociais positivas acontecem na Europa após a Revolução Industrial, com melhorias na higiene, cuidados médicos, educação, aumento da esperança de média de vida, etc. e até mesmo algumas mudanças negativas ao nível ambiental, por exemplo com a proliferação de fábricas têxteis e as necessidades de energia fóssil geradas. Mas não está tão estudado o que aconteceu com os agricultores da cultura do algodão, aos artesãos da fiação, aos mestres tecelões? Nas metrópoles da Revolução há relatos de revoltas de corporações de artesãos, mas e no sul o relato da decadência, nomeadamente do abandono da metrópole em relação ao território das ilhas de Cabo Verde? 


\section{RESISTÊNCIA CULTURAL PÓS INDEPENDÊNCIA EM CABO VERDE}

“(...) Acho que nenhuma outra manifestação artesanal atingiu tão alto nível técnico e artístico, no passado, entrando depois em decadência a partir do séc. XIX, mas ainda podemos ver belos espécimes, que chegaram até nós em Cabo Verde." (FIGUEIRA, 1998, p. 234)

É após a independência que este cenário é contrariado. Manuel Figueira, artista plástico cabo-verdiano, formado em Lisboa, regressa a Cabo Verde e integra o projeto da jovem nação, como responsável pelo Sector do Artesanato da Comissão de Investigação e Divulgação Cultural - C.I.D.C. (1975-1977), e as artistas Luísa Queirós com Isabel Duarte compõem a Sub-Comissão de Artesanato da referida C.I.D.C.

Em 1976 um grupo de professores, os referidos artistas, juntamente com Alexandrina Freitas, Clementina Chantre e Mercedes Leite criaram no Mindelo a Cooperativa Resistência que viria a tornar-se um instituto público em 1978, com 6 professores de Ciclo e Liceu, 4 cardadeiras e fiadeiras, o CNA - Centro Nacional de Artesanato, com sede no Mindelo e seu Centro Regional de Artesanato na cidade da Praia.

É o CNA que desenvolve um projeto de salvação da arte popular em Cabo Verde.

Cabo Verde, então colónia portuguesa e sem perspectivas de se desenvolver com base numa economia endógena, viu o seu artesanato a sucumbir, a perder-se no tempo. O único artesanato que sobreviveu com pujança, até à resolução industrial foi o de panaria, especialmente na ilha de Santiago. Aliás, terá sido a panaria o único artesanato nas ilhas que se afirmou na economia de então, reconhecido com alto valor de troca no continente africano e na Europa. (LOPES, 2013, p. 14).

O CNA interrompeu o anonimato em que o colonialismo tentara enterrar a cultura cabo-verdiana, e evidenciou uma resiliência indestrutível encontrada na pesquisa cultural de resgate dos saberes locais. Esse trabalho da Cooperativa Resistência e do CNA, encarou as dimensões da investigação, da educação e criação, orientadas para a consciência da riqueza artesanal e a partir da ideia combatente de que não há verdadeira Independência Nacional sem Independência Cultural.

Defender e desenvolver as manifestações de cultura do nosso povo, respeitar e fazer respeitar os usos, costumes e tradições da nossa terra, desde que não sejam contra a dignidade humana, contra o respeito que devemos ter para cada homem, mulher ou criança. (CABRAL, 1974, p. 51).

Foi estudada a arte popular num reconhecimento profundo do potencial da terra e sua especificidade das matérias primas locais como por exemplo: o barro para a cerâmica, as plantas (como algodoeiro, indigueiro, purgueira, cisal, bombardeira, bana- 
neira, cana) para os tingimentos, a tecelagem, os teares e a cestaria, e outros saberes de extremo valor cultural associado, como as oficinas de carpintaria, construção de instrumentos musicais, latoaria, ou as forjas, as redes de pesca, a confecção de bonecas, e ainda o compasso de fazer rebuçado, 'sucrinha' e pão. Mas é na panaria que recai o foco do CNA, escolhido pela excelência técnica, estética e simbólica dos panos, e pela escassez dos mestres tecelões que se encontravam já de idade avançada, determinando um manifesto até hoje conhecido : "NÃO DEIXAR MORRER A TECELAGEM".

É frequente dizer-se que as práticas culturais de raiz africana eram proibidas durante a colonização, e de fato muitas eram. No caso da panaria ela foi não proibida, mas veículo de fortalecimento de um regime de plantação e de escravatura, como vimos, objeto de alto valor (tanto o algodão inicialmente, como a panaria num segundo momento) no tráfico atlântico. O que sucede com a queda desse valor, é um abandono, e aquilo a que podemos chamar de objeto de desprezo pelas elites.

Também devido ao isolamento das ilhas, ao abandono por parte da metrópole, então portuguesa, as práticas artesanais sobreviveram após a revolução industrial, sobretudo ligadas a mestres nos meios rurais que mantiveram técnicas rudimentares e aplicadas a objetos utilitários. No entanto, muitos dos objetos de tecnologias artesanais que integravam o mercado em bens de utilidade em casa, ferramentas e outros utensílios foram, pouco a pouco, substituídas por objetos produzidos em série, produzidos por outras matérias primas que não estavam disponíveis no arquipélago, e que chegavam por via da importação ou enviados pela diáspora. Tudo isso concorreu para o condicionamento do gosto e dos hábitos da população local, bem como para uma subvalorização do artesanato que rapidamente sucumbiu a zonas cujo acesso aos bens era limitado.

A preocupação cultural, a necessidade desde sempre sentida de se funcionar como escola, sobrepunha-se pela força das circunstâncias aos objetivos "produtivos". (FIGUEIRA, et al., 1979, p. 77)

A preocupação cultural, a necessidade imposta pelo manifesto que citei, orientaram a missão do CNA, como uma escola preocupada simultaneamente com a cultura e com a produção. Na prática, colocou professores, artesãos e aprendizes, no lugar de aprender com os mestres tecelões, mergulhar nos seus segredos, as suas técnicas, os desenhos mais antigos. No olhar dos artistas e professores fundadores da cooperativa, esse caminho de aprender era o que permitiria recriar, enriquecendo a arte e transmitindo-a aos mais novos. No caso, com Nho Griga, último tecelão de Santo Antão, aprenderam o "calabedotche" (pano de retalhos coloridos) e com Nho Damásio, mestre de Santiago, o "Pano d' obra" (panaria cabo-verdiana). Após a aprendizagem concentrada, em Abril de 1976, a escola continuou organizando-se em trabalho prático, estudo da Panaria cabo-verdiana, desenho e pintura, levantamento de desenhos de panos tradicionais, tapeçaria e limpeza e organização do espaço. 

1.6.

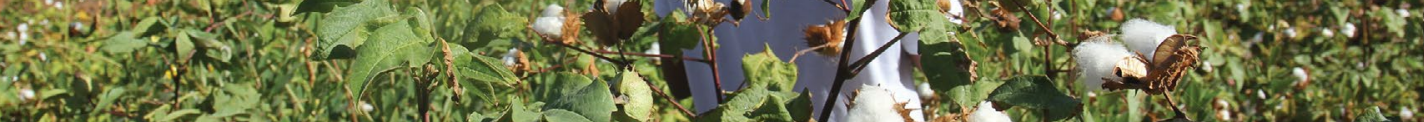

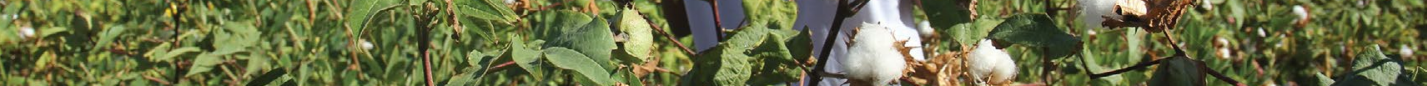
Who 3 ent

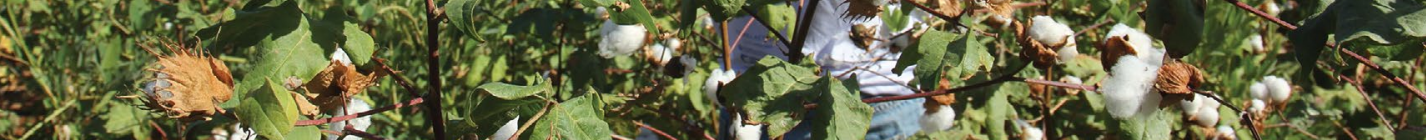

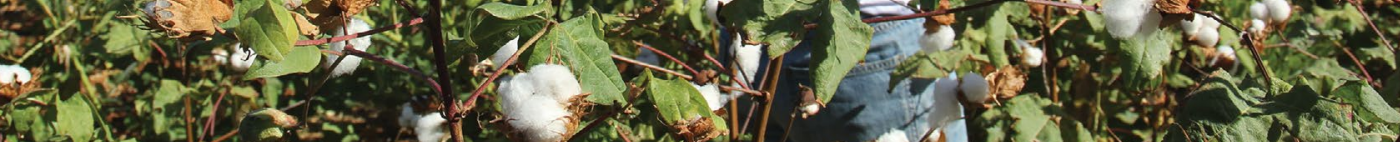

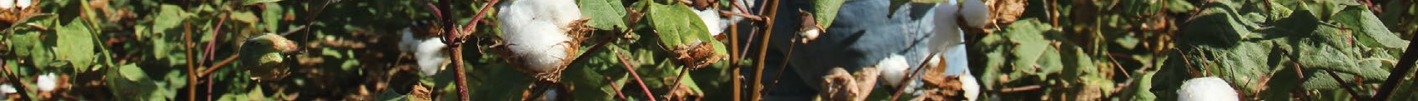
2.

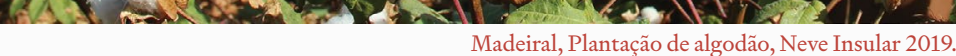

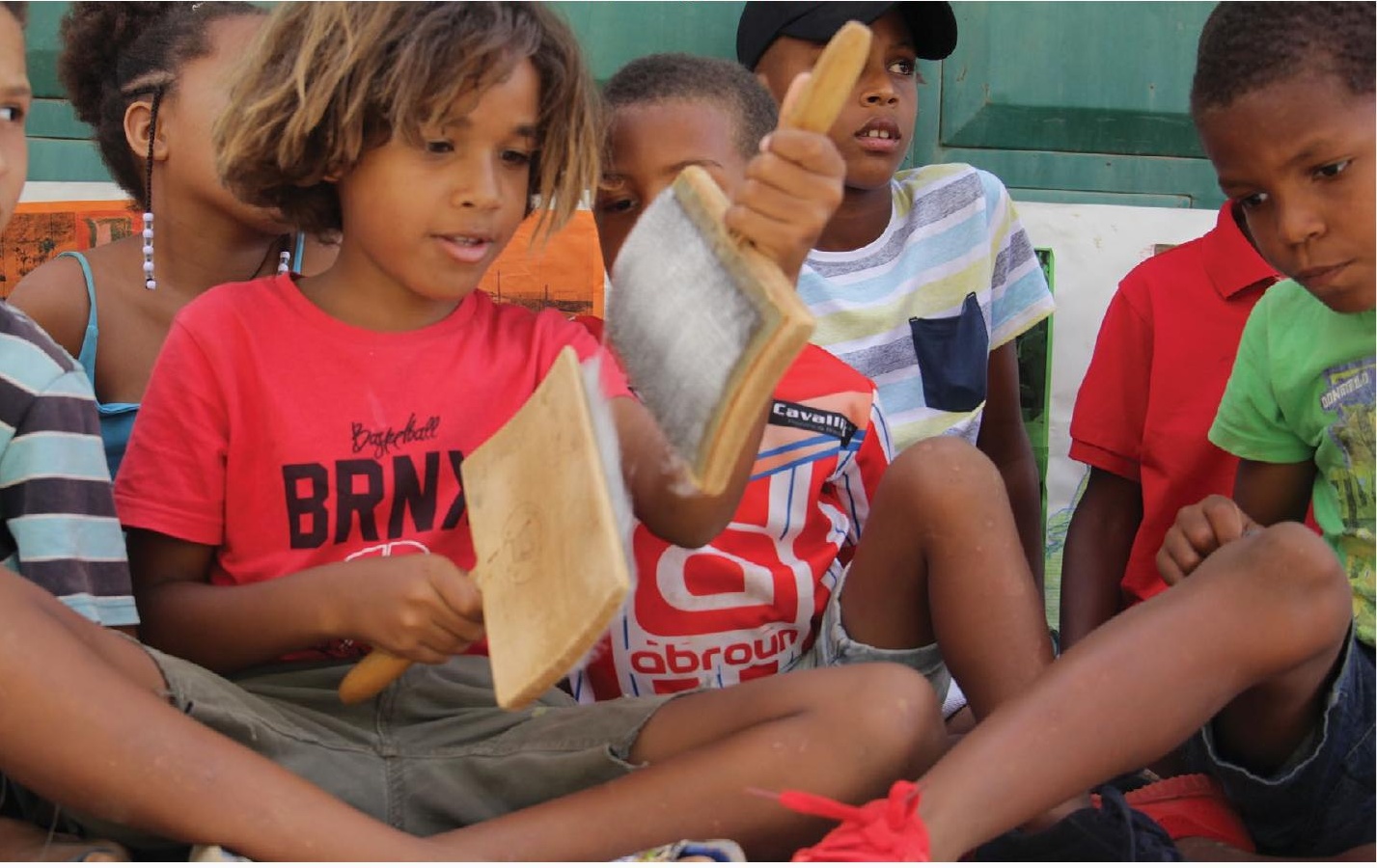




\section{NEVE INSULAR VERSUS DESEJO DE CONSUMO NO CENTRO DE GRAVIDADE NO PERÍODO COLONIAL E CONTEMPORÂNEO}

Afinal, pensando neste passado, o que faz ainda sentido criar no mundo contemporâneo com o algodão?

A indústria têxtil, em todo o seu ciclo de produção, desde os cultivos das fibras, sua transformação à confecção, tem vindo a ser marcada pela exploração de mão de obra barata, infantil, etc. e alimentada por um consumo globalizado e desenfreado de todos nós. Global Slavery Index ${ }^{2}$ denunciou 40,3 milhões de pessoas em situação de escravidão moderna em 2016 , das quais $71 \%$ são mulheres e os itens de vestuário estão entre os produtos de maior risco neste tipo de exploração.

Hoje, se no mundo, o algodão permanece no topo das pirâmides de produção escrava, massificada e estratificada, em Cabo Verde a produção ficou totalmente extinta. À ilha de São Vicente, onde não houve produção, chegaram sementes carregadas pelas pessoas e pelo vento, podendo-se encontrar a planta de forma espontânea pelos vales, e, um ou outro pé resguardado em jardim particular. É a partir dessas sementes que nasce uma pequena área de produção de algodão no Centro Agro-ecológico do Madeiral no interior da ilha. É nessa plantação que se enraíza o projeto "Neve Insular" em parceria com a Associação Agro-Pecuária do Madeiral e Calhau.

Com o início da plantação em 2018, na verdade uma ação simbólica de recolha de espécies selvagens, tratamento das sementes e sementeira laboratorial, foram obtidas reações diversas: muitas pessoas nos perguntavam, plantar nesta aridez de São Vicente? vão plantar algodão? é difícil competir com a indústria têxtil...; outras reagiam com as versões paternais: quando sai a primeira coleção de roupa? quando vos compro uma t-shirt?; e as outras mais utópicas: vão retomar a panaria, vamos ter de novo tecelagem!

Así, el conocimiento científico dominante alimenta un monocultivo de la mente al crear el espacio por el que desaparecen las alternativas locales; algo muy parecido a la introducción de monocultivos de variedades vegetales que desplazan y destroye la diversidade local. (SHIVA, 2008, p. 19)

Nesse princípio ficou evidente para nós que era imprescindível plantar o algodão em São Vicente, aquele que tínhamos visto refletido, de forma figurativa, no padrão do Pano d'obra, mas não apenas o algodão, enriquecer a terra e o entorno de uma biodiversidade que espelhasse a pluralidade de sentidos que queremos encontrar. Esse voltar à terra, ligou-nos aos saberes das agricultoras e agricultores, muito embora sobre o cultivo de algodão pouco se soubesse. Porém havia uma vontade comum de

\footnotetext{
${ }^{2}$ Mais informações: THE MINDEROO FOUNDATION. Walk Free Foundation. Global Slavery Index 2018., 2018. Disponível em: <https://www.globalslaveryindex.org/resources/downloads/>
} 
inventar futuro que nos ligasse da terra à cultura, e havia dados que davam à plantação uma certa segurança: as sementes eram de algodoeiros espontâneos da ilha; espécie de algodão de sequeiro (como à do nordeste brasileiro) que apresentava muito resistência à falta de água, e aos solos semi-áridos.

Essas sementes não vingaram bem, e recomeçamos de novo em 2019, agora com os princípios de agroecologia a apoiar-nos. Desta vez, organizámos um conjunto de oficinas de cruzamento de saberes e gerações, Mon na Terra (Agroecologia e Educação Artística), Tingimento natural e Cardar e Fiar.

Vou concentrar-me na primeira, que decorreu ao longo de vários sábados. A oficina Mon na Terra com foco na agroecologia, reforçou a importância dos saberes tradicionais da relação da pessoa com a natureza, perseguindo um pensamento, mas sobretudo uma prática ecológica e um movimento social e político transversal. Também serviu de suporte de cruzamento de experiências sobre compostagem, biofertilizantes, biopesticidas, cobertura vegetal e rega gota a gota. Sempre com a AAPCM, preparámos o terreno, $300 \mathrm{~m}^{2}$ e vingou uma plantação biodiversa de algodão, como espécie principal, com mandioca para abrir o terreno duro e ser comida em lanches, milho e feijão para nutrir o solo e pintar o arroz dos almoços coletivos que viessem, nos limites cana capim elefante para barreira de vento. Neste trabalho verificou-se que o algodão, sendo um cultivo que ninguém tinha experimentado, proporcionou na oficina um ambiente de troca e uma aprendizagem tanto para os/as agricultores/as como para o agrónomo, para as crianças que nos acompanharam, e para o colectivo deste projeto.

Ao longo de 2020 foram feitas três colheitas, somando $10 \mathrm{~kg}$. É muito pouco! - pensámos, mas logo chegaram $20 \mathrm{~kg}$ colhidos em pés espontâneos na ilha de São Nicolau por um artesão amigo, atento às nossas aventuras.

Desenhos desenrolados da terra, voltados para o mundo. Desenhos a trinta e quarenta mãos, Rastos das pegadas de quem cede e troca de lugar. (NEVE INSULAR, 2019)

Transportando o foco para a educação artística, com crianças dos $3^{\circ}$ e $4^{\circ}$ anos, professores/as das Escolas do Madeiral, de Ribeira do Calhau e do Calhau, e agricultores/as da AAPCM, se experienciaram questões em torno de uma aproximação da história do algodão no mundo e em Cabo Verde, da Planta do algodão, da exploração das matérias primas rurais como matérias visuais, o padrão da Panaria cabo-verdiana, e da transformação do algodão em fio.

Temos o problema de associar as práticas culturais tradicionais ao pobre (...) e os produtos artesanais são para os pobres. Temos de desmistificar esta ideia e, o melhor caminho para isto é a Educação. (MARÇAL, 2020, p. 67) 


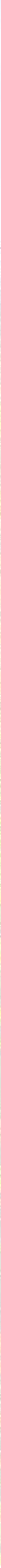


Livres de atividades extra e aulas específicas de todas as expressões e desportos conhecidos, as crianças do mundo rural estão disponíveis. Há sempre quem não queira, prefira o telemóvel que a tia mandou de França e não queira sujar a sapatilha que o pai enviou dos Estados Unidos. Para os professores é uma oportunidade de sair da sala, fazer uma pausa, porque alguém está a cuidar das crianças. Há os que, porém, se interessam, e se envolvem, querendo saber mais e carregando baterias de entusiasmo, num sábado, para os dias de rotina em sala que se seguem.

Atividades coletivas, desenhos na terra, desenhos com terra, desenhos da terra. Aprender os padrões, entender a estilização da figura do algodão, e conhecer a panaria com quem a faz em São Vicente, o mestre Sr. Marcelino dos Santos, que nos tem acompanhado desde o primeiro momento.

Foi importante para o projeto Neve Insular lidar com o desejo de produzir, de desenhar produtos, comprar matéria prima, entregar ao artesão para executar, vender produtos esteticamente apetecíveis com toque de 'ser d'terra'. Reconheço a velocidade com que se espera que se crie e se produza. Quantas vezes ouvimos, de pessoas que visitam as ilhas, mas e o que compramos aqui? a Neve Insular não tem produtos?

Ainda... como se diria em Moçambique. Ainda não. Porque sentimos que, para produzir de forma ecológica, sustentável e justa, é preciso criar uma rede solidária de sentido comum. Não há nenhum projeto que possa financiar isso, só o tempo o pode construir. Por isso, e como aprendi no 'movimento intercultural Identidades', o princípio dos Cs, conhecimento, confiança e cumplicidade tem marcado o percurso da Neve Insular. O desejo de criar e alimentar o ego de artista genial, trespassa cada um/uma, num centro de gravidade movido pelo consumo: o consumo de egos/nomes e vaidades, mas também o consumo de produtos, de fator exponencial do 'ter'. O algodão e a panaria em Cabo Verde ficaram fósseis do tempo colonial em que foram consumidos, usados e abandonados, tanto a obra de panaria, a matéria prima/natureza, como as pessoas. Hoje não queremos repetir esse cenário, não queremos alimentar um consumo que é parte do combustível do mundo desigual que vivemos.

É óbvio que uma cosmovisão dessemelhante à ocidental, que surge de raízes comunitárias e não capitalistas, existentes não apenas no mundo andino e amazônico, provoca conflitos e rupturas. Rompe igualmente com as lógicas antropocêntricas do capitalismo e dos diversos socialismos que existiram até agora. O Bem Viver, como anotamos, nos ordena a dissolver os tradicionais conceitos de progresso, em sua derivação produtivista, e de desenvolvimento, enquanto direção única, sobretudo com a sua visão mecanicista do crescimento econômico. (ACOSTA, 2016, pp. 97-98)

É difícil resistir ao encanto de conseguir mudar uma paisagem nua, num pequeno recanto vestido de verde, pontuado de branco e cheio de encontros com pequenos 
bichos que encontram um lugar mais reconfortante para viver. É difícil resistir aos olhos de crianças infoexcluídas e esquecidas pela cultura que fervilha na cidade e que invade as zonas rurais, que se sentiram valorizadas, e perguntam quando voltam ao algodão.

No artesanato tradicional é comum desaparecerem atividades, desaparecerem da circulação determinados objetos, porque deixaram de ter sentido a sua produção, deixaram de ser úteis ou funcionais enquanto objetos de seu uso quotidiano. (...) Contudo, esse mesmo objeto não deixou de ser útil no plano cultural, pedagógico, no plano técnico. (LOPES, 2013, p. 14).

É evidente para nós que, no terreno político, nos queremos distanciar de um produzir artesanato \& design pensando no turismo, na ótica do design da identidade nacional através do vestuário, e dos objetos com aplicações do pano d'terra (NOLASCO, 2018).

E quanto aos processos de trabalho, preocupa-nos a tendência da separação daquele que concebe, tradicionalmente o/a designer, e o/a artesã (o), a que que executa, segregações e hierarquias herdadas desde o princípio da revolução industrial, com o aparecimento da figura do desenhador das peças a serem reproduzidas pelos artesãos/operários, nos séc. XVII na Fábrica de Bodelins, e séc. XVIII e na Fábrica de Wedgwood (CARDOSO, 2008)-

E então, o que queremos? Viver este processo lento de conhecer o território e conhecermo-nos, conhecer e interferir na história das artes em Cabo Verde, a partir do passado e da ação interferente no presente deste território e daquilo que das culturas agrícolas, dos saberes populares se pode aprender para fazer face ao contexto de hoje.

Um pano - um objeto do qual pouco esperávamos esclarecesse o nosso conhecimento do mundo - aqui nos retém, presos à invisível teia que o liga à natureza humana, com os seus sentimentos e culturalidade (...). (JARDIM, 2020, p. 175)

Por isso, este texto serve-me de rasto da necessidade de entender melhor quem foram os artesãos que trouxeram o saber da panaria até nós, e como o algodão trespassou toda a história de ocupação do território de Cabo Verde. Mas também me serve para tornar consciente outras necessidades:

a) a escuta dos e das agricultores/as, das crianças do vale, dos/as artesãos/as. Estes têm-nos vindo a ensinar muito sobre o tempo de cada coisa, sobre a mobilização das pessoas, o rigor de como se organizam e produzem, pontual mas coletivamente. Madeiral é o lugar e a AAPCM que escolhemos para aprender a ser/estar coletivo, que escolhemos para aprender o tempo que o tempo tem, o sentido que o algodão 


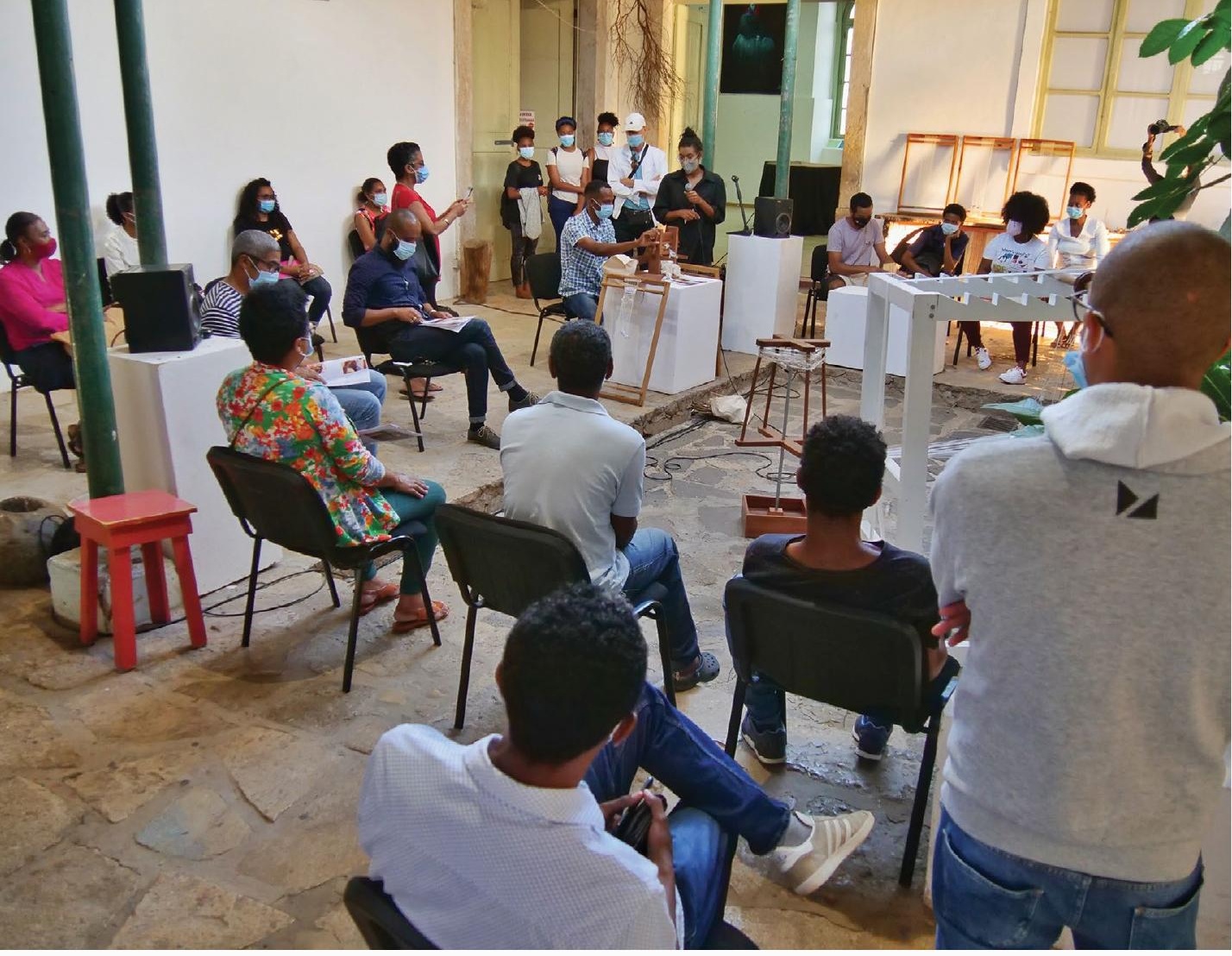

Mostra pública do grupo de formandos(as) de Ciclo de Algodão, Neve Insular, 2021. 
pode ter, na escala possível, na biodiversidade que queremos, na ilha árida e tantas vezes estéril que temos;

b) da atenção crítica que precisamos face ao nosso romantismo de mulheres que vivem na cidade e se sentem enamoradas pelo campo, portadoras de uma utopia, que como todas as utopias, está cheia de defeitos e erros próprios de quando se coloca esse lugar ideal em prática.

\section{REFERÊNCIAS}

ACOSTA, Alberto. O Bem Viver: uma oportunidade para imaginar outros mundos. São Paulo: Autonomia Literária, Elefante, 2019.

ANDERSON, Chris. Makers - a nova Revolução industrial. Amesterdão: Elsevier Editora, 2012.

CABRAL, Amilcar. P.A.I.G.C. Unidade e Luta. Publicações Nova Aurora.1974.

CABRAL, Iva. A PRIMEIRA ELITE COLONIAL ATLÂNTICA Dos "homens honrados brancos" de Santiago à "nobreza da terra" (Finais do séc. XV - início do séc. XVII). Praia: Universidade de Cabo Verde, 2013. Disponível em: <http://www.portaldoconhecimento.gov.cv/bitstream/10961/3316/1/ Tese de Iva Cabral - OS HOMENS HONRADOS BRANCOS DA ILHA DE S.pdf>.

CARDOSO, Rafael. Uma Introdução à História do Design. São Paulo: Editora Edgard Blucher, 2008.

FIGUEIRA, Manuel et al. Currículo das Actividades do período anterior à formação da "Cooperativa Resistência” até à presente data. Separata de Actas do Colóquio sobre Artesanato (Coimbra, 8 a 11 de Novembro de 1979). Coimbra: Serviços Municipais de Cultura e Turismo de Coimbra e Instituto Português de Património Cultural, 1983.

FIGUEIRA, Manuel. As Artes Plásticas e o Artesanato: ficção e tingidura. In: ALMEIDA, José Maria. (Org.). Descoberta das ilhas de Cabo Verde. Praia: Arquivo Nacional de Cabo Verde, 1998.
NEVE INSULAR. Mostra "Mon na Terra" no Centro Cultural do Mindelo. Boletim 2 Mindelo: Neve Insular, 2019.

JARDIM, Manuela. Memórias de um projeto. In: FERREIRA, I.; RAINHO, R. (Eds.). Grandes Conversas, Arte, Artesanato e Design - URDI17/18. Mindelo: Edições CNAD, 2020.

JOHNSON, Walter. River of Dark Dreams. Slavery and Empire in the Cotton Kingdom. Cambridge, MA: The Belknap Press of Harvard University Press, 2013.

LOPES, Leão. ARTESANATO NACIONAL: Por uma nova estratégia de políticas e incentivos para o sector, um estudo de campo ilhas de S. Nicolau, S. Vicente e Santo Antão. Cabo Verde: M_EIA, 2013.

MARÇAL, Artur. Identidade Cultura, Artesanato e Design. In. In: FERREIRA, I.; RAINHO, R. (Eds.). Grandes Conversas, Arte, Artesanato e Design - URDI 17/18. Mindelo: Edições CNAD, 2020.

MBEMBE, Achile. Crítica da Razão Negra. Lisboa: Antígona, 2014.

NOLASCO, Ana. Designing national identity through cloth: the pánu di téra of Cape Verde. Island Studies Journal, 2018.

SHIVA, Vandana. Los monocultivos de la mente (perspetivas sobre la biodiversidade y la biotecnologia). México: Fineo, 2008.

VEIGA, Manuel. Insularité et litteratture aux îles du Cap-Vert. Paris: Karthala, 1997. 



\section{PRÁTICAS DE EDUCAÇÃO ARTÍSTICA NO CONTEMPORÂNEO}




\section{Edite Colares, Elaine Barbosa de Sales}

\section{MUSENCANTANDO: GRUPO VOCAL E DE FORMAÇÃO MUSICAL PARA EDUCADORES}

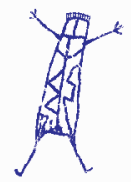

\section{RESUMO}

Sabe-se que a música é uma forte aliada aos processos de desenvolvimento humano e que como expressão estabelece ligação com a cultura, fortalecendo a identidade de um povo. Este artigo aborda discussões sobre a valorização da cultura popular e suas manifestações no processo de musicalização de futuros professores em formação na Universidade Estadual do Ceará, pelo Projeto Arte na Escola, e traz questionamentos acerca desses processos. Busca-se apresentar algumas das experiências vivenciadas no Musencantando, grupo vocal, que tem seu repertório composto de Música Brasileira, e reúne-se a fim de compreender os caminhos que norteiam os encontros musicais com este grupo e seus resultados, bem como seus problemas e desafios. Apresenta as propostas e trajetória do grupo, as estruturas dos encontros e de que forma ocorre a aquisição de conhecimentos e como se reflete sobre o impacto que se deseja obter fora do âmbito acadêmico na vida dos integrantes que o compõem o grupo. Traz, além disso, o questionamento, pela preocupação dos possíveis motivos da pouca vivência da cultura popular no meio escolar e no que este distanciamento pode resultar. Palavras-chave: Cultura popular. Musicalização. Música brasileira. Aulas de música.

\section{ABSTRACT}

It is known that music is a strong ally in human development processes and that as an expression it can establish a connection with culture, strengthening the identity of a people. This research addresses discussions on the use and valorization of popular culture and its manifestations in the process of musicalization of adults at the State University of Ceará, through the program Arte na Escola, and raises questions about these processes. It also seeks to present some of the experiences lived in Musencantando, a Brazilian Music study group, in order to understand the paths that guide music lessons and their results, as well as their problems and challenges. It presents the proposals and trajectory of the group, the structures of the meetings and how knowledge is acquired and whether an impact can be obtained outside the academic scope in the lives of the members who compose it. In addition, it raises the question, due to the concern about the possible reasons for the little use of popular culture and what this scarcity may result from now on.

Keywords: Popular culture. Musicalization of adults. Brazilian music. Music classes. 


\section{INTRODUÇÃO}

Para Vygotski, em Imaginação e Criação na Infância, a atividade criadora é o que faz o homem ser um ser que se volta para o futuro, erigindo-o e modificando o seu presente. (...) A psicologia denomina imaginação ou fantasia a essa atividade criadora baseada na capacidade de combinação de nosso cérebro. (...)

"No cotidiano, designa-se como imaginação ou fantasia tudo o que não é real, que não corresponde à realidade e, portanto, não pode ter qualquer significado prático sério." (2018, p.16)

Desta maneira, para o psicólogo, todo o mundo da cultura, é produto da imaginação humana e baseada na sua criação. Alerta-nos...

"Se levarmos em conta a presença da imaginação coletiva, que une todos esses grãozinhos não raro insignificantes da criação individual, veremos que grande parte de tudo que foi criado pela humanidade pertence exatamente ao trabalho criador anônimo e coletivo de inventores desconhecidos." (2018, p. 17)

Estas reflexões nos levaram às razões que moveram o grupo de estudo da Rede Arte na Escola, no Polo Ceará a ter acreditado na realização deste processo de formação em musicalização de seus membros, desde 2005. Ou seja, podemos concluir que ao combinar um repertório musical basilar, com elementos fundantes da música garantimos ao futuro professor deter saberes indispensáveis para fazer canto coral, com seus estudantes, nos anos iniciais da educação básica.

De acordo com Maura Penna (2008) "musicalizar é desenvolver os instrumentos de percepção necessários para que o indivíduo possa ser sensível à música, aprendê-la, recebendo o material sonoro/musical como significativo" (PENNA, 2008. p. 31). Assim sendo, a articulação de estratégias no campo de atuação do canto, em um grupo vocal, com estudantes de Pedagogia, foi registrada neste estudo, tomando o ano de 2018 como referência. O grupo chegou a uma formação composta por sete vozes femininas e uma masculina, e fez-se necessária para efetivação de resultados condizentes a este intento, uma trajetória crescente no desenvolvimento e exploração das capacidades vocais, com o propósito de reforçar as potencialidades individuais, para que assim, se consolidassem uma factual prática coletiva de canto. O programa, naquele ano, abordou a musicalização através do canto coletivo e outros assuntos inerentes à música e a cultura em seu aspecto estético, histórico e técnico, visando aprimorar a concepção musical com a aplicação e execução de músicas folclóricas e regionais, que são parte do cancioneiro popular brasileiro, mais especificamente, buscando estabelecer conexão com manifestações tradicionais 
brasileiras, constituindo, consequentemente, sua valorização representando-as, como foi feito com o Pastoril, o Maracatu ou o Coco.

\section{CANTANDO COCOS}

O gênero musical Coco, apresentou-se, como repertório de canto no grupo Musencantando, naquele período e contou com a realização de estudo etnográfico das práticas de Cocos no Ceará, apoiadas por demais atividades desenvolvidas pelo Projeto Arte na Escola, como a pesquisa em dança feita, nos últimos anos, respectivamente, pelo Grupo de Pesquisa Cultura Brasileira, Educação e Práticas Pedagógicas, que propôs variadas formas de integração entre pesquisa e extensão, favorecendo a maior a assimilação e acomodação desta manifestação de forma mais complexa, percebendo-a no lugar aonde ocorre suas práticas culturais.

Esta reflexão debruça-se sobre à análise dos processos realizados no Projeto Arte na Escola, projeto de Extensão da Universidade Estadual do Ceará - UECE, na atividade específica com o grupo intitulado "Musencantando", grupo vocal que estuda Música Brasileira, dentro do projeto de formação de professores de Artes e da Educação Infantil, na Rede Arte na Escola, Polo Ceará, que visa oferecer formação a professores com práticas de música cantada, buscando alcançar professores e universitários, que atuam no ensino de artes e nas escolas de Educação Básica, adotando o canto como instrumento primeiro no processo de musicalização.

O estudo objetiva compreender os aspectos estruturais que permeiam os encontros, seus resultados e desafios; apontar o canto como relevante incentivo numa trajetória emancipadora de formação; e ainda, considerar a utilização da música folclórica como relevante, enquanto valorização da cultura local, que legitima o sentimento de pertencimento, pela música. Vale salientar a importância desta atividade, enquanto, programa que abrange à comunidade acadêmica, e oferece estímulos à arte na vertente musical popular.

Tanto a pesquisa sobre a cultura popular, quanto as atividades de extensão, estão ainda em andamento, mantendo-se em permanente ebulição, desde 2005, o que justifica uma possível estranheza no tocante à sistematização deste estudo somente agora, uma vez que este é um recorte periódico do ano de 2018. Teve seu surgimento no grupo de estudo em musicalização, que foi se transformando ao longo dos anos, para ir tomando a forma que hoje tem. Desde o início o intento é a preparação de professores da educação básica para cantarem com seus alunos, com conhecimento necessário e uma boa vocalização. Pôs-se em prática no grupo vocal, um aperfeiçoamento na musicalização, bem como na técnica vocal, para cantar o cancioneiro popular brasileiro.

Segue-se ao planejamento de ensaios e programas de estudos, que se realiza sempre ao início de cada semestre, o que rege e norteia o processo de ensino/apren- 
dizagem, tornando possível o desenvolvimento de um processo continuado pela análise e prática de canto. Este sempre é um trabalho realizado com dois regentes, um musical e uma pedagógica. Parte dos estudos se repetem periodicamente, seja para reforçar, seja pela grande flutuação de participantes, visto que se alteram os grupos de estudantes na universidade à medida que se seguem os semestres. Convictas de que é extremamente necessário educar musicalmente o educador da educação Infantil e dos primeiros anos do Ensino Fundamental dotando-o de conhecimentos mínimos sobre música, canto e musicalização, almeja-se como Teka Alencar de Brito:

"Trazer a música para o nosso ambiente de trabalho exige, prioritariamente, uma formação musical pessoal e também atenção e disposição para ouvir e observar o modo como os bebês e crianças percebem e se expressam musicalmente em cada fase do seu desenvolvimento, sempre com o apoio de pesquisas e estudos teóricos que fundamentem o trabalho." (2003, p.35)

\section{MUSENCANTANDO}

Este grupo objetiva abordar discussões sobre a valorização da cultura popular e suas manifestações no processo de musicalização de futuros professores, estudantes da Universidade Estadual do Ceará, partícipes do programa Arte na Escola, que trazem questionamentos acerca desses processos formativos. Busca-se, além disso, apresentar algumas das experiências vivenciadas no Musencantando, grupo vocal de música brasileira, que em 2018, passou a assim se chamar por escolha coletiva, por seus sentidos e significados, por ser música cantada, por lembrar museu, que foi assumindo e que queremos problematizar, o modo como a música diz de nós, quem somos, a fim de compreender os caminhos que norteiam os encontros com a música e seus resultados, nesta formação docente, bem como seus problemas e desafios. Apresenta-se aqui as propostas e trajetória do grupo, quanto a estrutura dos encontros e de que forma ocorre a aquisição de conhecimentos e a possibilidade de obter um impacto fora do âmbito acadêmico na vida dos integrantes que o compõem. Trazendo, além disso, o questionamento, pela preocupação dos possíveis motivos de tão pouca vivência da cultura popular no meio universitário e no que essa escassez resulta na formação de professores.

A lei de Diretrizes e Bases da Educação Brasileira, que se encontra publicada no Diário Oficial da União, Lei 9394/96, estabelecia o ensino da arte como componente curricular obrigatório nos diversos níveis da Educação Básica, quando foi alterada pela Lei no 12.287 , de 13 de julho 2010, salientando-se também a presença das expressões regionais e sua importância para Educação Básica. Ficando expresso, assim, pelo novo texto da lei em seu $\int 2 \stackrel{\circ}{\circ}$ 
"O ensino da arte, especialmente em suas expressões regionais, constituirá componente curricular obrigatório nos diversos níveis da Educação Básica, de forma a promover o desenvolvimento cultural dos alunos"

Caminhava-se rumo ao reconhecimento da importância e a destinar alguma atenção ao patrimônio cultural brasileiro na ocasião em que se institui a regionalidade e consequentemente a valorização da cultura local.

Mas este primeiro olhar sobre a Cultura Popular na escola foi impedido de se propagar como método e prática de ensino, tenha em vista que a Base Nacional Curricular Comum, em 2017, publicada bem no final do ano, acarretou ao processo de consolidação da área, ou seja, um retrocesso em que retira a visibilidade e frustra quanto ao aprimoramento do que é a Arte no Ensino Fundamental. Vemos, então, retroagir para dentro da área de Linguagem, o ensino de artes, perdendo destaque, todo um campo de conhecimento, que deixa de ser reconhecido como tal e fragiliza-se.

Pretende-se traçar uma trajetória deste projeto e como este se constitui pedagogicamente na formação dos licenciandos, educadores em formação, revelando a importância da música neste quadro preparatório, não apenas no contexto educacional, mas na preservação das raízes culturais, incorporadas no objetivo do grupo e no pensamento de que é preciso se deter conhecimentos básicos de música e canto, para lecionar à crianças pequenas.

"Deixem a música falar por si mesma, não por associações. Música não é propriedade privada de certas pessoas ou grupos. Potencialmente, todas as músicas foram escritas para todas as pessoas. Sejam curiosos em relação à Música. Não se contentem em ficar só nas suas preferências musicais, pois, ninguém está traindo seus velhos hábitos pela aquisição de novos. Este horizonte pode seguir se expandindo; em toda a sua vida haverá coisas novas a descobrir" (SCHAFER, 1991, p. 23).

O Instituto Arte na Escola, articula uma Rede composta por 39 universidades parceiras e instituições de ensino de Arte, em todo o território nacional há mais de trinta anos atuante. Desde 2005 tem Polo na UECE, vêm agindo na formação de acadêmicos, para musicalização e canto, colaborando para que estudantes de Pedagogia, possam pelas ações de formação continuadas, chegar às escolas com noções básicas de canto e cultura popular. O Musencantando, grupo vocal ao qual nos referimos neste artigo se insere, neste projeto em Rede, no qual efetivamente interagimos com educadores em formação e com sua participação criativa, contribuem com o seu processo de aprendizagem/formação ou ele não acontece.

Desta mesma forma vai se atuando profissionalmente aprendendo e ensinando a valorização cultural de nossa gente, de nossos saberes regionais, numa relação dialógica com outras culturas e realidades capazes de colocar os docentes em sincronia 
com as necessidades educacionais de educação da sensibilidade, das emoções, das expressões culturais de nossos estudantes.

Ser professor nos primeiros anos de escola passa por apresentar aos pequeninos nossas canções de ninar, nossas brincadeiras cantadas, brincadeiras de roda, parlendas, contos e adivinhações, além é claro das fábulas e outros conhecimentos indispensáveis aos educadores de crianças para que possam apresentar não só as primeiras letras, mas o nosso rico patrimônio cultural, razão pela qual também devemos educar, para conhecermos a nós mesmos, primeiramente.

O presente artigo apresenta às atividades vivenciadas pelo grupo Musencantando, destacando o canto de músicas populares, como elemento de identidade, em que prioriza-se a apreciação e execução de músicas do cancioneiro tradicional nordestino, juntamente com a prática do canto coletivo que promove expressões que favorecem as relações sociais de forma intercultural, com destaque ao patrimônio cultural cearense, em especial o cancioneiro dos festejos e gêneros do Ceará.

\section{METODOLOGIA}

Apresentamos aqui o primeiro registro da experiência do Grupo Vocal Musencantando, de forma descritiva e reflexiva, que aconteceu como parte da pesquisa, de caráter qualitativo: As Manifestações Artístico Populares no Âmbito da Escola Básica, na qual se busca entender a importância da música popular tradicional na Educação Infantil e no Ensino Fundamental, bem como na formação de professores deste nível de ensino, almejando ser incentivo ao aprofundamento do conhecimento por parte deles, sobre a cultura musical brasileira, como forma de desenvolvimento de prática docente consciente e criativa.

Objetivando cumprir um papel mediador da aprendizagem no tocante ao ensino de artes, o Arte na Escola, Polo UECE, acredita ser também a música, forma de expressão que desempenha grande colaboração no desenvolvimento humano, e que enquanto fenômeno universal, se mobiliza nesta expressão, compreendendo-a como forma de comunicação universal capaz de construir e/ou reforçar os valores estéticos, éticos, sociais e culturais nos professores e estudantes. O Musencantando é aberto à comunidade, mas sua ação tem foco no desenvolvimento de alunos de Pedagogia e Música da UECE, onde vêm sendo trabalhados a prática coletiva de canto, a teoria musical aplicada, a inicialização à prática percussiva, através do corpo e de confecção instrumentos recicláveis, e iniciação instrumental, a partir do canto de um repertório de músicas populares brasileiras.

Reconhecendo aspectos subjetivos presentes nos encontros, considera-se fundamental uma estruturação na qual se desenvolveu execuções de atividades que se ajustaram com a realidade dos integrantes, respeitando seus saberes e concepções, possibilitando a democratização musical articulando pesquisa e exten- 
são. Para isso, todo o processo é acompanhado de estudos tanto musical como etnográfico, promovendo o planejamento das reuniões, para que fosse a construção de uma trajetória crescente, embora singela, que buscou efetivação e significação dos processos e impressões que foram sedimentados em conhecimentos de canto, bem como, um repertório regional mínimo do cancioneiro popular brasileiro. $\mathrm{O}$ plano que aludimos, no ano de 2018, dispôs, além da prática de canto de Cocos, a confecção de instrumentos recicláveis, para incorporar ao trabalho de percussão, como instrumentos rítmicos, obtendo assim uma maior apreensão dos instrumentos que caracterizam esta manifestação, a fim de explorar a sensibilidade auditiva, como possibilidade de realização musical, tornando possível, uma das propostas do programa, qual seja, o desenvolvimento rítmico. Considera-se também necessário o contato com rudimentos de partitura, e estudo de parâmetros sonoros de forma branda, para que possam entender esses elementos básicos e aplicá-los na execução musical no canto em coro, de maneira que possam transpor para sala de aula com crianças.

O acervo do grupo se encontra na sede do Arte na Escola, Polo Uece, material disponibilizado em arquivos físicos e digitais disponível aos integrantes, que buscam desenvolver técnicas simples, como cânones e abertura de vozes, e mais recentemente possibilidade de junção de vozes aos instrumentos de percussão.

\section{CONSIDERAÇÕES}

Dos processos vividos no grupo Musencantando, considera-se relevante ressaltar pontos que visam favorecer aos integrantes à participação e que, como metas, foram atingidas, através de uma vivência que garantiu um fazer musical a partir da realização da prática coletiva do canto, que estabeleceu uma boa socialização e parceria entre seus membros, acredita-se como Jacques Rancière que; $A$ comunicação razoável se funda na igualdade entre a estima de si e a estima dos outros. Ela favorece a contínua verificação dessa igualdade. (2015, p.114)

Os encontros tornaram-se momentos que ofereciam bem-estar, tanto na interação pessoal, quanto no reconhecimento do valor da música como arte fundamental; que permitia considerar os cuidados com a voz, visto que o público atingido foi de professores e que esses precisam atribuir grande atenção a ela como seus instrumentos de trabalho; bem como pelo estímulo à valorização da cultura e da música popular brasileiras e também em seus valores locais.

Constatou-se a importância da música para além do seu sistema convencional de valor estético, mas reconhecendo-a como forte elemento socializador; relevante é exaltar como se atingiu o desafio de formalizar o que os integrantes já conheciam, intuitivamente, e favorecer que compreendessem a música enquanto comunicação, expressão e conhecimento histórico e socialmente construídos. Entendendo seus méto- 
dos e possibilidades, para além do que já conheciam, fez se que percebesse a demanda por uma busca constante de materiais possíveis para a implementação das concepções que possam colaborar cultural e educacionalmente para formação docente.

Concluiu-se por frisar que a experiência no Musencantando não se resumiu à prática conjunta de canto, mas também à apreensão de concepções teóricas básicas dos signos musicais, percepção rítmica e auditiva, num fazer musical que se aproximou da comunidade escolar e dos professores, de modo que esta experiência pode colaborar na percepção e vivência musical na escola por estes educadores.

As músicas tradicionais populares compõem um gênero musical, que reúne situações cotidianas da vida de um lugar em ocasiões coletivas de celebração e rituais, práticas que permeiam a vida comunitária fazendo o indivíduo situar-se como parte de um conjunto societário, que o identifica como sujeito histórico, com vínculos ancestrais. São articuladas às características do lugar e ao modo como se foi reagindo às condições reais de existência. Desta maneira, parte-se de um lugar de pertença deste grupo que optou por músicas brasileiras e, no período em questão, dedicou-se ao estudo de um repertório de Coco, um dos ritmos mais comuns nas tradições cearenses.

A Música aqui emana da comunidade, mas vem por ela sendo esquecida e é possível encontrar numerosas pessoas que não sabem que o Coco é um gênero musical por aqui nascido, e que compreende seu versejar rico em rimas, na palavra ritmada, reunindo música e gesto, rapidez de raciocínio, e movimentos bem articulados com a poética popular...No entanto, é preciso reconhecer nas rimas uma porta de entrada para a música, embora não seja a única forma de poética musical. Ou seja, o Coco, é embolada na bolada de embolar, para parafrasear Antônio Nobrega, que engrossa o coro de quem defende a ideia de ser imprescindível um conhecimento da Cultura Brasileira, pelo povo brasileiro, o que Nóbrega apresenta sempre tão brilhantemente.

Imagina-se uma atividade musical capaz de causar interesse a meninos e meninas dos anos escolares iniciais, apresentando não só Antônio Nóbrega, mas Jackson do Pandeiro, Luiz Gonzaga e muitos outros Mestres do Cancioneiro Brasileiro. Voltar-se sobre si, sobre a música de raiz, ao Coco, ao Maracatu, ao Pastoril, são conhecimentos indispensáveis ao cearense, ao nordestino, ao Brasileiro.

De onde o Coco veem? De ancestrais, de pais e remotas avós, que com suas crenças e força foram deixando registros de um modo de ser e de estar no mundo, que é de quem vai pisando a terra, batendo o chão pra fincar-se ao solo, na sala de reboco, para plantar o Coco, querendo beber a água, cantar com todos uma bela canção. Foi cantando embolada, depois de cantar umas toadas de maracatu e outras coisinhas mais, que se foi ampliando o repertório até se apresentar em palco do Auditório Central da UECE, por duas vezes em 2018 e realizar brincadeira de Coco, em roda na Praça Paulo Freire, no Centro de Educação, da UECE, que se resolveu refletir, aqui, sobre este processo ao tematizar a experiência desenvolvida no Musencantando.

São muitos os aspectos a se destacar, mas não se esgotará aqui estas reflexões sobre o Musencantando, a escolha pela música de raiz cearense, o canto coletivo, 
a apresentação cênica. Com estes destaques queremos elucidar seu teor orgânico quanto à música como comunicação e expressão de cunho coletivo. A metodologia é pesquisa-ação, a música é de criação local, em grupos enraizados na cultura cearense, como o Maracatu, o Pastoril e o Coco, vivenciados também pelo grupo, como forma de reconhecimento e valorização do patrimônio imaterial cearense.

A visita às cidades de Aquirás e do Crato, no interior do Ceará, para coleta etnográfica de músicas de Coco, foram momentos importantes da pesquisa musical que gerou material visual e de áudio, que ainda podem ser usados como dados de pesquisa, pois nem todo o material produzido foi possível de se trazer a público, ainda. Uma vez que fomos todos surpreendidos pela Pandemia do COVID19, e este que seria um resultado em forma de MOSTRA acabou por ser apresentado aqui em formato de artigo.

\section{REFERÊNCIAS}

BRITO, Teca Alencar de. Música na educação infantil. São Paulo: Peirópolis, 2003.

COLARES, Edite. Ensino de Artes e Educação/Edite Colares... [et al.] - Fortaleza, Brasil Tropical, 2001.

COLARES, Edite. As Festas Populares o Ensino das Artes. Fortaleza, EdUECE, 2017

RANCIÈRE, Jacques. OMestre Ignorante. Belo Horizonte, Autêntica Editora, 2015.
SCHAFER, R. M. Oouvidopensante. São Paulo: Unesp, 1991. PENNA, Maura. Música(s) e seu ensino. Porto Alegre: Sulina, 2008. SOUZA, Jusamara. Reflexóes, Experiências e Inovaçôes/Luiz Botelho Albuquerque, Pedro Rogério, Marco Antônio Toledo Nascimento [organizadores]. Fortaleza: Edições UFC, 2015.

VYGOTSKI, L. S. Imaginação e criação na infância. $1^{\mathrm{a}}$. Ed. - São Paulo : Expressão Popular, 2018. 


\section{Rosália Menezes}

\section{A POÉTICA DE GEGO: TRAJETÓRIA LÚDICA DE UMA LINHA}

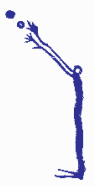

Este texto, no formato de ensaio, teve a primeira versão, ainda um embrião de interesses, durante uma visita ao Museu de Arte de São Paulo, para participar de um ciclo de palestras, seminários e filmes que integravam parte de uma pesquisa que resultaria na exposição Histórias das mulheres, histórias feministas e Histórias feministas, mulheres radicais. A exposição ocorreu durante o ano de 2019, compondo uma mostra ampla que acolhia diversos estilos e gêneros pictóricos de artistas mulheres de diferentes épocas e regiões do Mundo. Parte da exposição foi dedicada a obras feitas por mulheres até o final do século XIX, onde se manteve contato com inúmeras artistas e obras desconhecidas do catálogo oficial da história da arte. Outro eixo temático da exposição apresentou as obras de 30 artistas e coletivos de distintas nacionalidades, mas que conduziam propostas estéticas, problematizando feminismos plurais, interseccionando com questões de raça, dissidências sexuais, direitos humanos, apagamento e invisibilidade da produção artística realizada por mulheres e a hegemonia masculina e branca na história da arte canônica.

Todos esses temas foram discutidos em seminários, nas falas de algumas artistas, ativistas, curadoras, pesquisadoras, e mantinham pertinência crítica com as demandas do século XXI. Nos seminários e durante a visita aos espaços expositivos foi possível confrontar a diversidade estética, temática, geográfica, de suporte e técnica na composição das imagens das obras das artistas. Essa multiplicidade de tendências desmente a ideia, estabelecida à extensão dos séculos, de que haveria um modelo de arte feminina ou, ainda, abordagens estéticas apropriadas para o universo das mulheres. Essas formulações ideológicas atuam como dispositivos reguladores para garantir restrições, no decurso da história, aos espaços expositivos de salões, galerias e museus, e ao comparecimento da mulher aos manuais da história da arte. Linda Nochlin, num texto de 1971, que se tornou referência quando a temática envolve arte e gênero, faz uma pergunta que provoca incômodo, se pensada com amparo nos questionamentos que suscita: "Por que não existem mulhe- 
res artistas?”. A produção estética de mulheres que vivem ou viveram em regiões intensivamente demarcadas pela colonialidade, com suas epistemologias -como ocorre na América Latina e na África - foi desqualificada e excluída do mapa da arte, circuito que é gerenciado por um índice de valores que privilegiam, historicamente, artistas europeus homens e brancos.

No transcurso do ano de 2019, inteiramente dedicado a obras de artistas mulheres, ocorreram exposições monográficas de Tarsila do Amaral, Djanira da Motta, Lina Bo Bardi, Anna Bella Geiger, Leonor Antunes e Gego. Entre as tantas propostas estéticas visitadas nos espaços internos e externos do Museu, algumas obras me impressionaram delicadamente e umas de modo impactante, como ocorre com o conjunto da obra da artista teuto-venezuelana Gertrud Goldschmitd (Gego) (1912 - 1994). Talvez, não sei ao certo, pela singularidade das escolhas estéticas e das estratégias poéticas na maneira da Artista lidar com espaço em conexão com os materiais adotados, incitando uma relação de contiguidade entre o corpo da obra e o corpo do espectador. É uma complexidade acolhedora, orgânica e lúdica. A exposição monográfica de Gego consta de um panorama de 150 trabalhos que vai do início dos anos de 1950 aos anos de 1990. Gego é uma artista que desenvolveu séries de trabalhos em desenho, gravura, têxteis cadernos de artista, escultura e instalações interativas em estruturas metálicas tridimensionais.

Este ensaio não pretende realizar uma análise minuciosa da obra da Artista. A intenção é tecer algumas considerações com base numa chave de interpretação que tensiona entre-lugares do corpo em contato com as obras e as reverberações desse encontro, ancorado na noção de tempo expandido da experiência. É precisamente esse tempo expandido, um tempo não linear, que conjugo aqui, a imagem da espiral passível de trazer de volta um tempo que nunca é o mesmo.

O ensaio é desenvolvido em duas partes. No primeiro momento, apresento a biografia breve da Artista, interligando-a, de modo abrangente, com sua produção artística toda realizada em solo venezuelano. Posteriormente, teço algumas impressões, dobras do pensamento que interligam a ideia de deslocamento espacial e estético, procedente do contato com a produção da Artista, ao pensamento prático de decolonizar e des-aprender. Assim, sem muito alarde, o intento é se deixar atingir por essas reverberações da experiência estética. A pedra foi lançada no lago.

\section{A LINHA, ESPAÇO, CORPO, TRANSPARÊNCIA}

Gego (Gertrud Louise Goldschmidt) nasceu em primeiro de agosto de 1912, em Hamburgo, em uma família judia. Graduou-se em Arquitetura e Engenharia em 1938, e, em 1939, no início da Segunda Guerra Mundial, ela migrou para a Venezuela para escapar da perseguição antissemita na Alemanha. Lecionou na Faculdade de Urbanismo na Universidade Central da Venezuela e, em 1952, recebeu a nacio- 
nalidade venezuelana. Em 1950, Gego iniciou seu trabalho artístico em Caracas e participou do grupo Abstração Geométrica, da Venezuela. Este abriu um diálogo estético com as tendências vanguardistas europeias da abstração geométrica e da Arte Cinética. Ela incorpora, no entanto, ao racionalismo austero e metafísico do abstracionismo geométrico europeu, elementos caóticos, fragmentados, rizomáticos e orgânicos que desestabilizam o rigor característico da tendência europeia (PEDROSA, 2019). Essa abordagem diferenciada é uma guinada estética realizada por importantes artistas e grupos latino-americanos. Em 1959, foi publicado no Brasil o Manifesto Neoconcreto, que reclamava a participação do corpo na experiência poética (entre os integrantes neoconcretistas, estão os artistas Ligya Clark e Hélio Oiticica).

No contexto latino-americano, levando em conta as idiossincrasias regionais, havia uma proposta estética que reivindicava novas dinâmicas sensoriais com o objeto artístico, incluindo a figura do espectador como outro polo da composição artística. Em vez de uma recepção passiva, solicitava-se que o público comparecesse, num encontro ativo com a obra. As produções $\mathrm{Os}$ Bichos, de Lygia Clark, e Parangolés, de Hélio Oiticica, são exemplos de experiências estéticas, pelo seu caráter manual e dançante, que entrelaça obra, artista e público. No caso de Gego, a natureza sensória do trabalho acontece por via da luz e da transparência em estruturas aéreas abertas, desnudas, mas que engendram espaços aconchegantes que acolhe o corpo do espectador: "Por isso mesmo, estão entre as obras venezuelanas que mais se aproximam de uma das particularidades do neoconcretismo carioca: o contato corpo a corpo do artista com a matéria" (JIMÉNEZ, 2010, p.34). Redes e malhas reticulares armadas com fios de arame e esferas de chumbo recobrem o espaço arquitetônico compondo ambientes abertos, flexíveis e penetráveis. O espaço visual equaciona-se com o espaço relacional, a linha extrapola o espaço bidimensional do papel e se instala na tridimensionalidade do espaço. As investigações estéticas de Gego são objeto de uma contínua transformação, mas mantêm uma organicidade vital que perpassa todas as séries: esculturas vibracionais e cinéticas dos anos de 1950 e 1960, Chorros (1970-71), Reticuláreas cuadradas (70-73), Columnas (1971), Columnas Reticuláreas cuadradas (1972), Troncos (1974-77), Dibujos sin papel (1976-88), Esferas (1976-77), Bichitos/Bichos (1987-91). Constitui obra extensa, experimental, e que deixa uma rica contribuição formal para os artistas da segunda metade do século XX. A obra de Gego vista de modo inteiro, malgrado sua ampla diversidade plástica, pertence a uma tradição de artistas que concebe uma práxis poética como um espaço de encontro com outros corpos e objetos no mundo.

Uma das séries de trabalhos expostos no MASP são as experiências cinéticas visuais. São obras estruturadas com base no movimento como possibilidade de romper a condição estática da obra, mas não apenas representando o movimento por meio de uma técnica ilusionista, mas transformando a própria obra em uma peça móvel que recebe a ação da aragem, da luz e do espaço que evolui sob a perspectiva óptica do observador (o efeito paralaxe). Objetos compostos, tridimensio- 
nais, ganham contornos visuais diferentes, na dependência do posicionamento do corpo do observador. Em sua pesquisa plástico-visual, a Artista se interessou por investigar “(...) três formas de sistemas: linhas paralelas, nós lineares e o efeito de paralaxe - pelo qual a forma de um objeto estático muda devido ao movimento da posição de observação do espectador". (IMBROISI et al, 2020). Ela explorou a linha como objeto escultural no espaço e suas inúmeras possibilidades de instaurar outros campos perceptivos e imersivos, incluindo transparência, energia, tensão e movimento óptico (ibidem).

As séries de Gego são tecidas por uma linha que acompanha o processo inventivo da artista, o desenho e a gravura sobre papel, a costura dos têxteis e a linha como objeto escultórico no espaço tridimensional. A linha lúdica e inquieta que estabelece teias e nos convida a habitar; linhas irregulares e mutantes flutuando no espaço, um estado de acontecimento que se expande e se duplica em sombras e luz, "Um objeto quase mágico, com efeito. Um objeto a fornecer imagens, da maneira mais inesperada e mais rigorosa que existe" (DIDI-HUBERMAN, 2010, p. 88).

Em confronto com esses aspectos, a Artista cria uma série de módulos em formato de teias de arame, as Reticuláreas (áreas de rede), peça considerada como um dos seus trabalhos mais importantes - uma ambientação no formato de uma imensa teia de segmentos de metais conectados, um invólucro de corpos maleáveis que, erguidos, concedem configuração ao espaço em teias desnudas, vazadas e atravessadas pela luz. Suas Reticulares são urdiduras que se conectam, formando habitações provisórias em espaços relacionais.

O crítico e historiador Yve-Alan Bois escreve um texto comentando as Reticuláreas - um poema grego que fala sobre o aprisionamento da cigarra na teia da aranha. Ele ressalta a experiência de ser capturado pela teia Gego, uma experiência que envolve espaço, matéria, olhos, emoções, pele e músculos:

É como se sentíssemos de imediato que só é possível ter uma experiência completa da obra através do corpo todo - e não apenas de um olhar imaterial; como se o mundo de Gego nos libertasse instintivamente dos constrangimentos das convenções tradicionais da observação (em museus). Como a cigarra leitora do epigrama da Grécia Antiga, cantamos nossa liberdade dentro do tecido do texto. O gênio de Gego está em ter transformado a sua a teia de aranha, destinado a ser um dispositivo de captura, num instrumento poético de libertação. (BOIS et al, 2006, p.51).

Um dos importantes encontros com a obra de Gego é realizado pela bailarina e filósofa venezuelana Sonia Sanoja (1932-1917), no Museu de Arte Contemporânea de Caracas (MACC). Sanoja realiza uma performance intitulada Coreogegos. A Bailarina constrói partituras corporais num improviso lúdico com as cordas (Chorros) que compunham parte da exposição de Gego. Pelas fotografias, é possível imaginar 


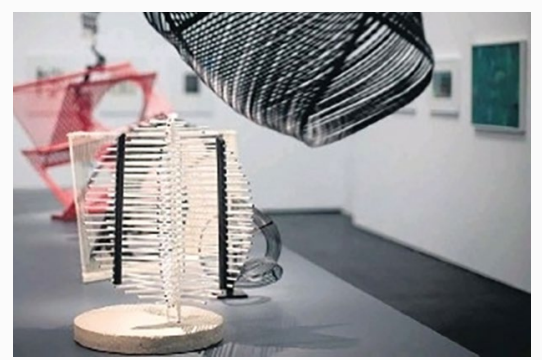

Fig. 1 - A linha emancipada. Foto: Acervo MASP/SP (2019).

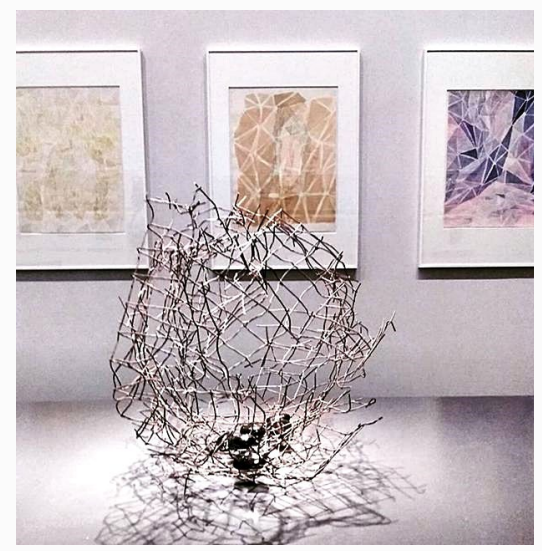

Fig. 2 - A linha Emancipada. Foto: Acervo MASP/SP (2019).

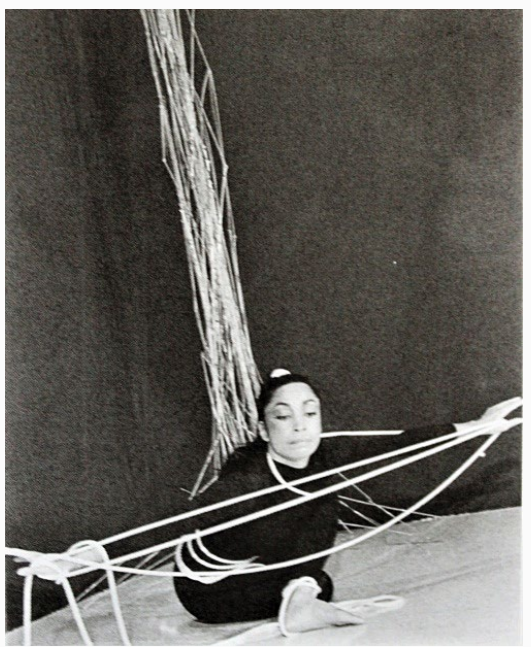

Fig. 4 - Sonia Sanoja dançando Coreogegos. Foto: Reinaldo Armas Ponce (1977). 
os dois limites plásticos (corpo e corda) que se reinventam num inesperado encontro. A despeito do encontro entre a obra de Gego e Sonoja, esse crítico de arte e estudioso da obra de Gego acentua que “(...) ambiente de Gego, dessa maneira, se comporta como uma partitura indeterminada, em que ler é mover-se através dela". (ENGELHARD, 2019, p.45).

O contato com a obra de uma artista nos ensina de forma comovente como (des) aprender de maneira fecunda. Não procurando oferecer uma resposta a cada um dos pontos que a experiência em si mesma suscita, impõe-se que se retenha, antes, o que dela em nós reverbera e permite uma abertura para uma sensibilidade crítica, conceitual e prática. "Abrir, nesse sentido, equivale a falar em termos de processo e não em termos de coisas fixas". (DIDI-HUBERMAN, 2010, p. 209). Retomo a metáfora do tempo, citada no início deste escrito, como a figura de uma espiral, e recolho a pedra, a fim de mais uma vez atirá-la no lago.

\section{REVERBERAÇÕES DECOLONIAIS}

O ponto de partida desta reflexão foi um deslocamento territorial, corporal, mas, também, epistemológico e estético. $\mathrm{O}$ avizinhamento com a produção artística prolifera um campo de interrogações sobre as relações entre aprender e ensinar arte, transpondo o ideal de formação, mas muito mais para romper com os modelos formativos da maioria das instituições educacionais, "Consideramos que o essencial é o acesso à experiência estética a partir do contato com a atitude e o trabalho dos artistas, portanto, como pensar e propor as mediações estratégicas para compatibilizar os dois termos da equação: educação e arte?" (FAVARETTO, 2010, p.225).

Eis uma pergunta que ressoa e inquieta, mas não é feita para respostas imediatas nem definitivas. É o caso de deslocar o ponto e traçar linhas, construir rizomas à moda de Gego, em direção a outras referências visuais, geopolíticas, étnicas, periféricas e de gênero; considerar a singularidade de outros modos de produção e vivência artísticas apagadas ou invisibilizadas pela história canônica da arte; a experiência como possibilidade inquietante de recriar-se e de construir uma rede de sentidos através de diversos campos de sensibilidade estética (imagética, gestual, oral, verbal).

Nosso mundo social humano se estrutura por via de um conjunto de valores oriundos das ideologias históricas que, com o passar dos tempos, são transformadas em regras da normativa social. Interpretamos o mundo com suporte em nossas experiências, que estão enredadas num sistema globalizante de economia capitalista neoliberal. Em grande parte, nossos projetos de fuga dos enquadramentos corporativos, ou de tentativa de transgressão dos modelos engendrados pelo sistema-mundo globalizado, são capturados, reiterados e formatados no "fichário" 
das representações sociais. Não há, todavia, alguma transformação sem que haja conflito entre sistemas de valores, em pequenos gestos revolucionários e desobedientes das regras excludentes.

As experiências estéticas influenciam e desempenham relevante papel na elaboração dos nossos critérios pessoais de gosto, valores e identidade. Que ferramentas, coletivas e singulares, são capazes de acionar e transformar nossos espaços de ensino em arte e com arte de pensamento prático decolonial? Que estratégias são susceptíveis de reverter o desinteresse, que propicia desconhecimento, e o escasso contato com ambientes artísticos entre jovens estudantes e futuros professores de escolas periféricas?

A sugestão em pensar modos de estabelecer espaços educacionais direcionados para o pensamento prático da decolonização instiga a rever práticas e conteúdos excluídos dos currículos educacionais, sistema que reitera formas patriarcais e os universais coloniais do saber. A arte, entretanto, não está sujeita ao universal e absoluto. Os conceitos clássicos de beleza harmônica, perfeição e equilíbrio não são os únicos critérios que nos permitem vivenciar o prazer ou o desprazer perante um objeto ou situação artística.

A decolonização articula-se na proposta de um "giro decolonial", termo criado, em 2005, pelo filósofo e teórico da decolonialidade Nelson Maldonato-Torres (BALLESTRIN, 2013). A perspectiva, decolonial é um movimento de libertação do pensamento e uma insurgência aos modos e práticas do colonialismo. Não existe, todavia, unanimidade sobre o uso do termo, pois alguns pesquisadores e autores preferem o uso do vocábulo, descolonial. A feminista e pedagoga decolonial Catherine Walsh situa sua posição teórica e política de caráter ativista, ao indicar a importância do termo decolonizar:

Suprimir la "s" y nombrar "decolonial" no es promover un anglicismo. Por el contrario, es marcar una distinción con el significado en castellano del "des". No pretendemos simplemente desarmar, deshacer o revertir lo colonial; es decir, pasar de un momento colonial a un no colonial, como que fuera posible que sus patrones y huellas desistan de existir. (2009, p. 14-15).

A supressão do "s" não constitui a adoção de um anglicismo, segundo o texto supracitado de Catherine Walsh, mas a introdução de uma diferença, essa diferença no des castelhano, pois, a análise crítica da autora, o pensamento e a prática decolonial não pretende apenas desarmar ou desfazer o colonial. Há uma proposta em curso que revela novas formulações em perspectiva decolonial, em que as abordagens se orientam para as práticas de grupos e comunidades de povos tradicionais, movimentos sociais, abordagem das questões de gênero pensadas numa concepção de experiência histórico-crítica e ampliada, o resgate de autoras e autores invisibilizados, questões latino-americanas, o problema ecológico e o domínio dos recursos natu- 
rais pelo capital globalizado - numa abordagem de (re)existência para decolonizar desde as margens. Em suma, há uma tentativa de elaborar outras subjetividades, alimentada num imaginário multirreferenciado na cultura afro-latino-americana.

Aos pesquisadores e educadores fica o desafio de inventar outras chaves interpretativas para situar a produção artística contemporânea e reconhecer seus domínios; tornar visível, ampliar bibliografias, construir com diferentes campos do conhecimento e pensar uma arte feminista como estratégia epistemológica decolonial; constituir experiências educacionais incluindo a produção de artistas mulheres latino-americanas, mulheres negras, povos indígenas, populações periféricas. Isto implica pensar a produção artística assentada num recorte geopolítico numa visão não excludente de corpos, culturas e visões de mundo.

Até aqui, apresentei expectativas propositivas, um modo particular de reverberar outras possibilidades que cruzam os campos da arte e da educação; de deslocar a visão, o corpo e o pensamento para referências pouco visitadas, arriscar alterações em conceitos e práticas legitimadas pelo tempo histórico. Supondo que é possível (des) aprender o que já se pensava saber para não submergir a uma mera repetição.

\section{REFERENNCIAS}

AMOR, Mônica. BOIS, Yve-Alain; BRETT, Guy; PERUGA, Íris. Desafiando Estructuras. Gego. Livro catálogo de exposição. Porto, Museu de Arte Contemporânea de Serralves; Barcelona: Museu de Arte Contemporânea, p.18, 20b06-2007.

AMOR, Mônica; BOIS, Yve-Alain; BRETT, Guy; PERUGA, Íris. Desafiando Estructuras. Gego. Livro catálogo de exposição. Porto, Museu de Arte Contemporânea de Serralves; Barcelona: Museu de Arte Contemporânea, p.51, 2006-2007.

BALLESTRIN, Luciana. América latina e o giro decolonial. Revista brasileira de ciência política, $\mathrm{n}^{\circ} 11$. Brasília, maio - agosto, 2013, p.189-117.

DIDI-HUBERMAN, Georges. O que Vemos, o que nos Olha. São Paulo: Editora 34, 2014.

ENGELHARD, Vered. O movimento reticular de Coreogegos: rumo a uma ética da forma. Livro-catálogo de exposição realizada no MASP, pp 42-59, 2019.

FAVARETTO, Celso. Arte contemporânea e Educação. Revista Iberoamericana de Educación. N.53, pp. 225-235, 03/2010.
IMBROISI, Margaret; MARTINS, Simone. Gego: A Linha Emancipada | MASP | SP. História das Artes, 2020. Disponível em: https://www.historiadasartes.com/ sala-dos-professores/gegoa-masp-sp/. Acesso em 20 de outubro de 2020.

JIMÉNEZ, Ariel. Desenhar no Espaço: artistas abstratos do Brasil e da Venezuela na coleção Patrícia Phelps e Cisneros. Porto Alegre: Fundação Iberê Camargo, 2010.

PEDROSA, Adriano. Gego: A Linha Emancipada |MASP | SP. História das Artes, 2020. Disponível em: https:// www.historiadasartes.com/sala-dos-professores/gegoa-masp-sp/. Acesso em 20 de outubro de 2020.

WALSH, Catherine. Interculturalidad, Estado, Sociedad: Luchas (de)coloniales de nuestra época. Universidad Andina Simón Bolivar, Ediciones Abya-Yala,: Quito, 2009. Disponível em http://www.flacsoandes.edu. ec/interculturalidad/wp-content/uploads/2012/01/ Interculturalidad-estado-y-sociedad.pdf . Acesso 20 de outubro de 2020 . 
Francisco Harley de Oliveira Almeida

\section{ENCANTARIAS DE FEIRA: ENCRUZILHADAS FÍLMICAS}

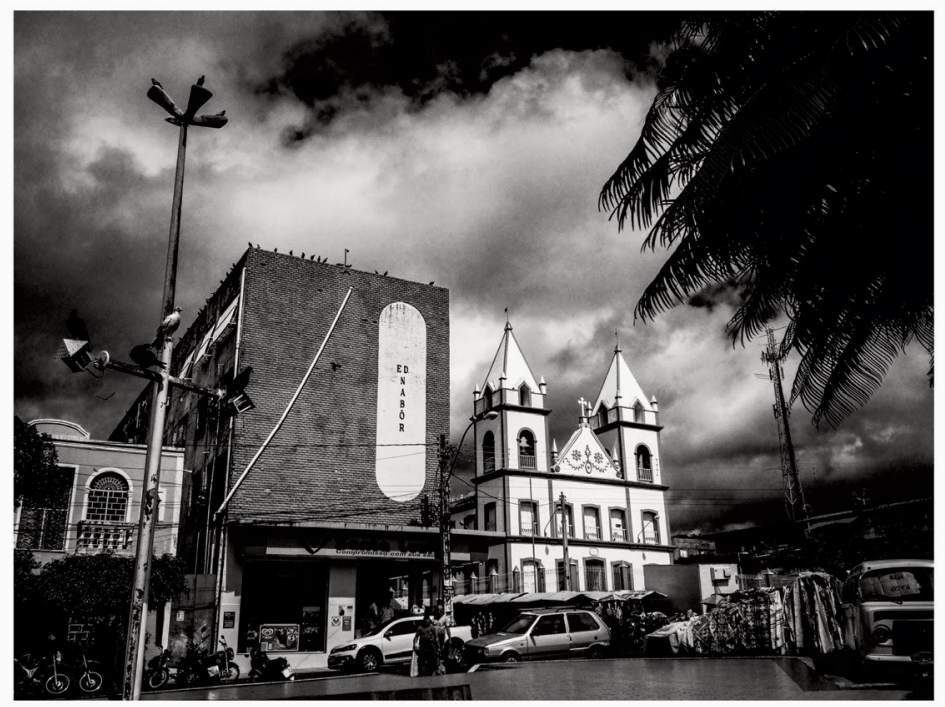


Feiras livres e mercados populares são terreiros de perambulação, território de encontros, encruzilhadas de saberes e práticas das mais diversas cosmologias. Esse chão de encruzilhadas e encantarias imprime modos de vida, entre fluxos e ocupações de gente, bichos e plantas. Fluxos de intensidades e velocidades assinalam rastros e ecos que reverberam nas diferentes camadas de ocupação.

Composições e atravessamentos estão presentes nesse trabalho que se inspira em saberes de terreiro como possibilidade de dialogar com "olhares nômades" em pleno sertão central do Ceará, abarcando as cidades de Redenção e Baturité, no Brasil. Uma experimentação imagética capaz de conservar e produzir afetos.

Pensar esses terreiros de feira e mercados populares no Sul global, como possibilidade de transversalização com as mais diversas produções de conhecimento, é um exercício que promove aproximações e vizinhanças. Esse traço cria novos contornos, não apenas geográficos, mas também existenciais.

Nessas encruzilhadas de saberes e práticas é possível uma aproximação em especial com a educação, no sentido de encontrar aberturas para novos possíveis, rompendo com a ideia de uma única forma de se pensar e produzir conhecimento. Nesse sentido, a fotografia e o audiovisual serviram de ferramentas capazes de realizar um exercício cartográfico das práticas cotidianas de feiras e mercados populares. Trazendo por exemplo, questões contra- coloniais para o debate nas mais diversas esferas de discussão, inclusive fora do território acadêmico.

A segmentarização que nos torna peças e engrenagens deste modo de vida violento e cruel é manifesta na carne.

Este trabalho enquanto experimentação e pesquisa através da imagem fotográfica também produziram outros formatos.

No audiovisual, os registros e as relações, imprimiram atravessamentos de gente, bichos, plantas e máquinas tecnológicas.

A cada encontro, infinitas são as possibilidades de se produzir novas ressonâncias com os mais diversos mundos. 

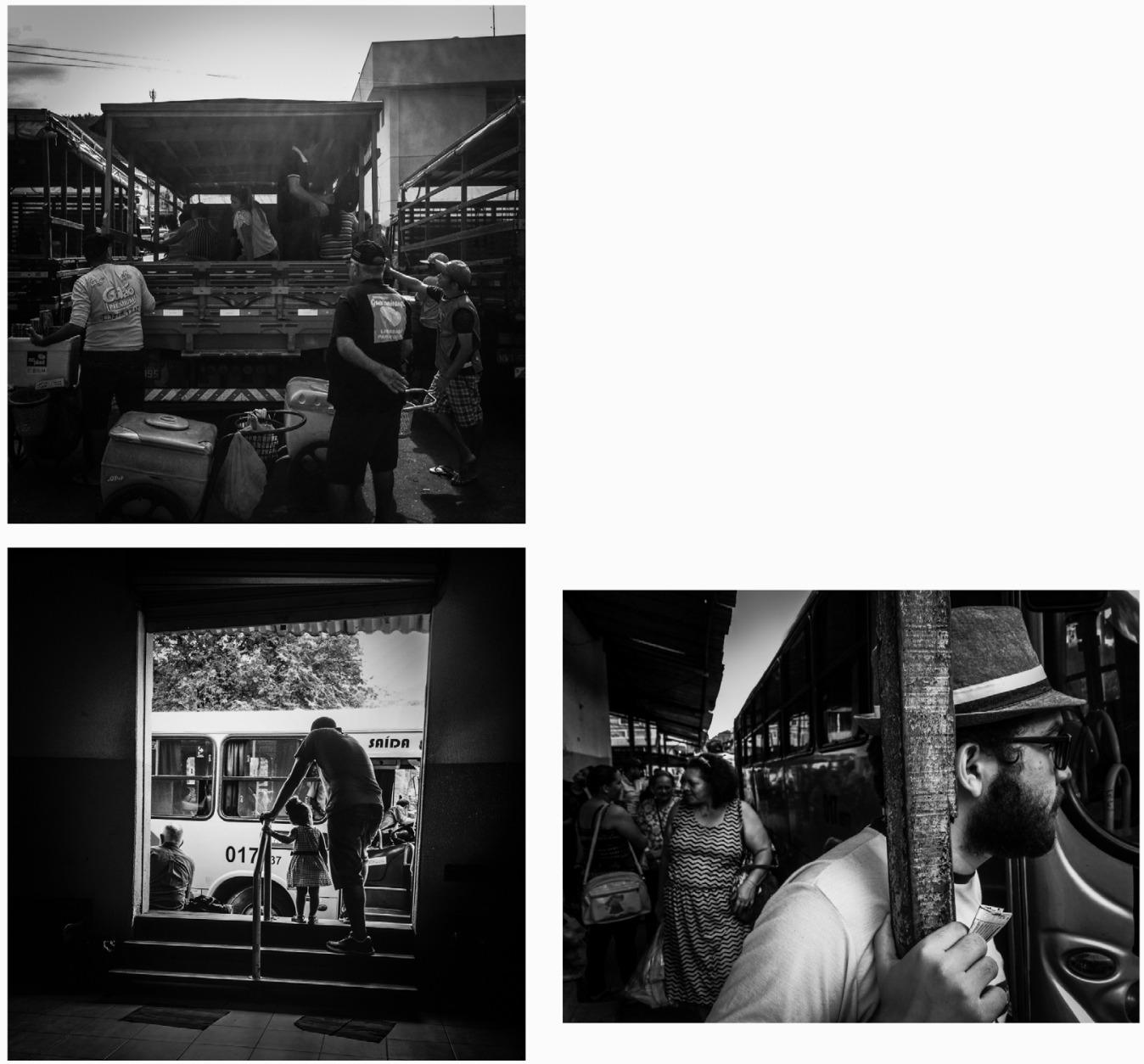

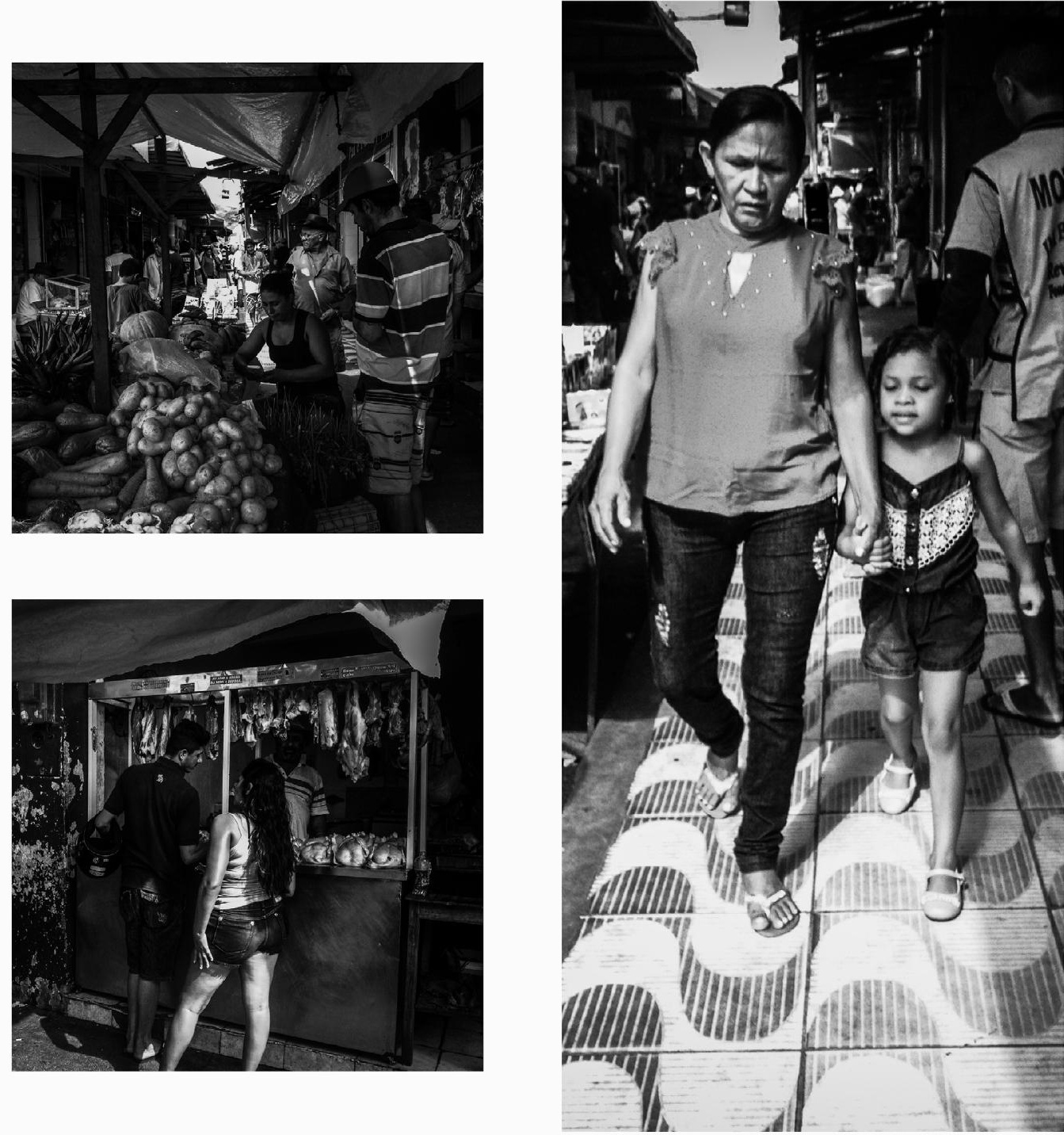

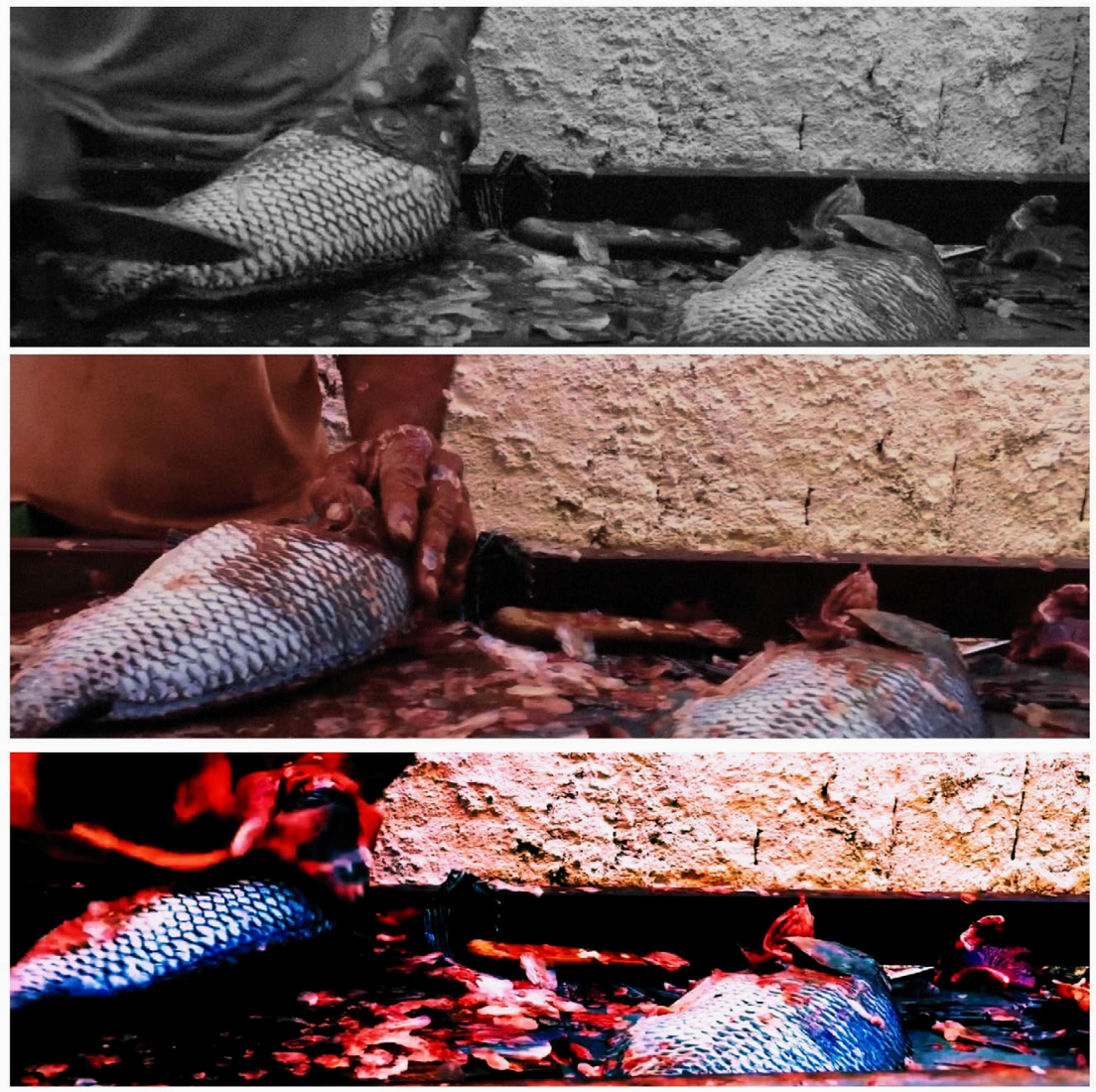


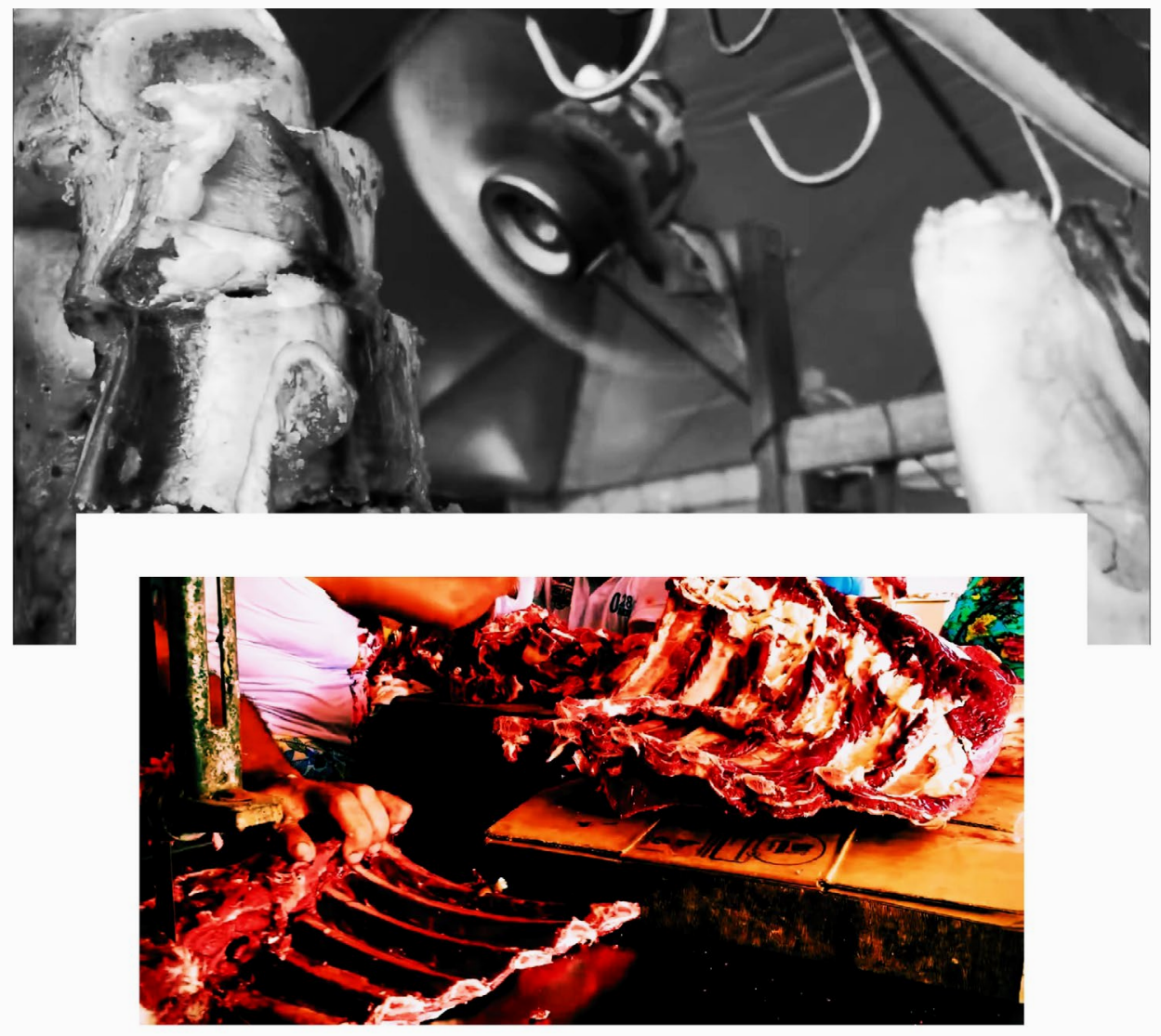



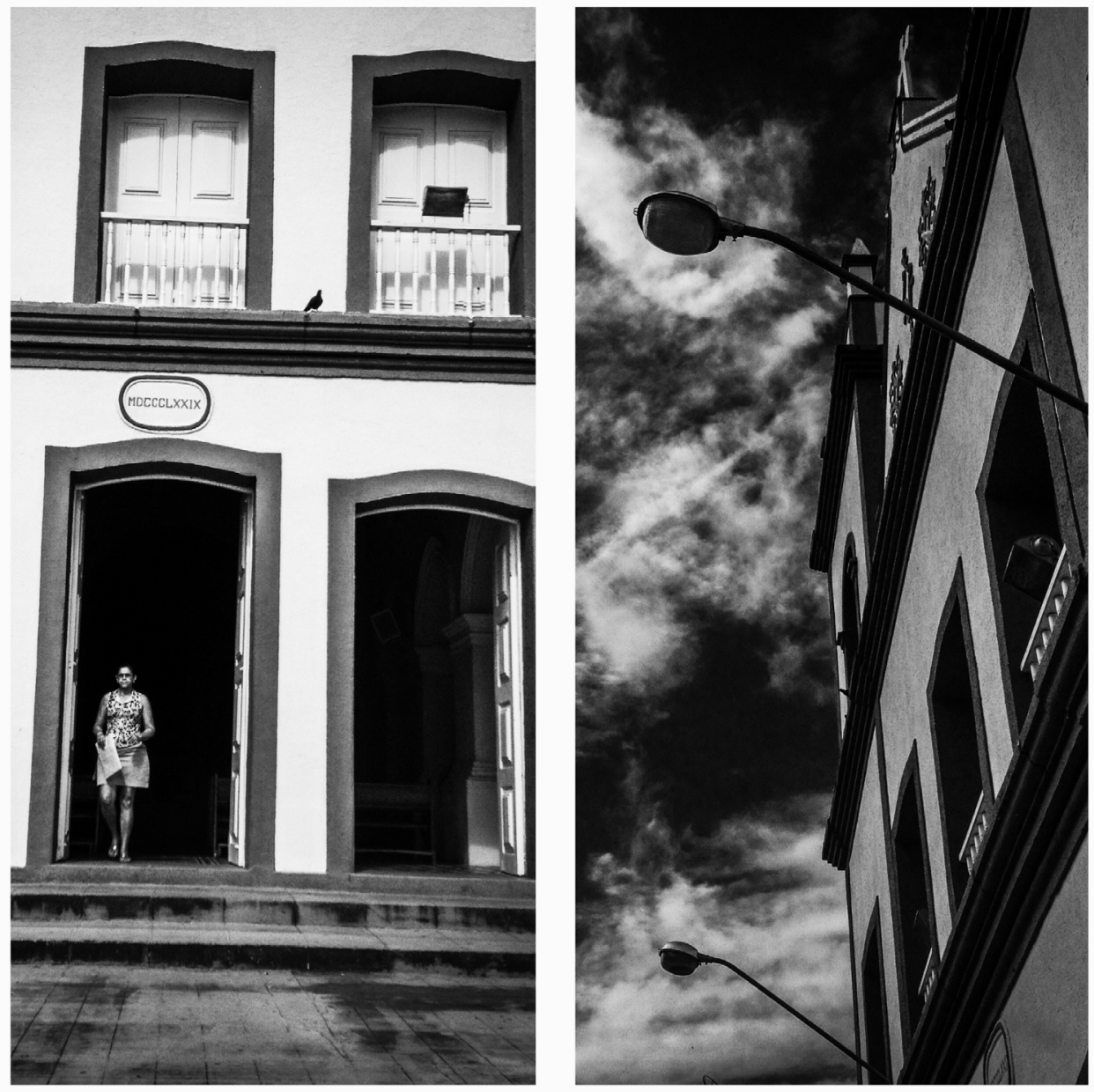

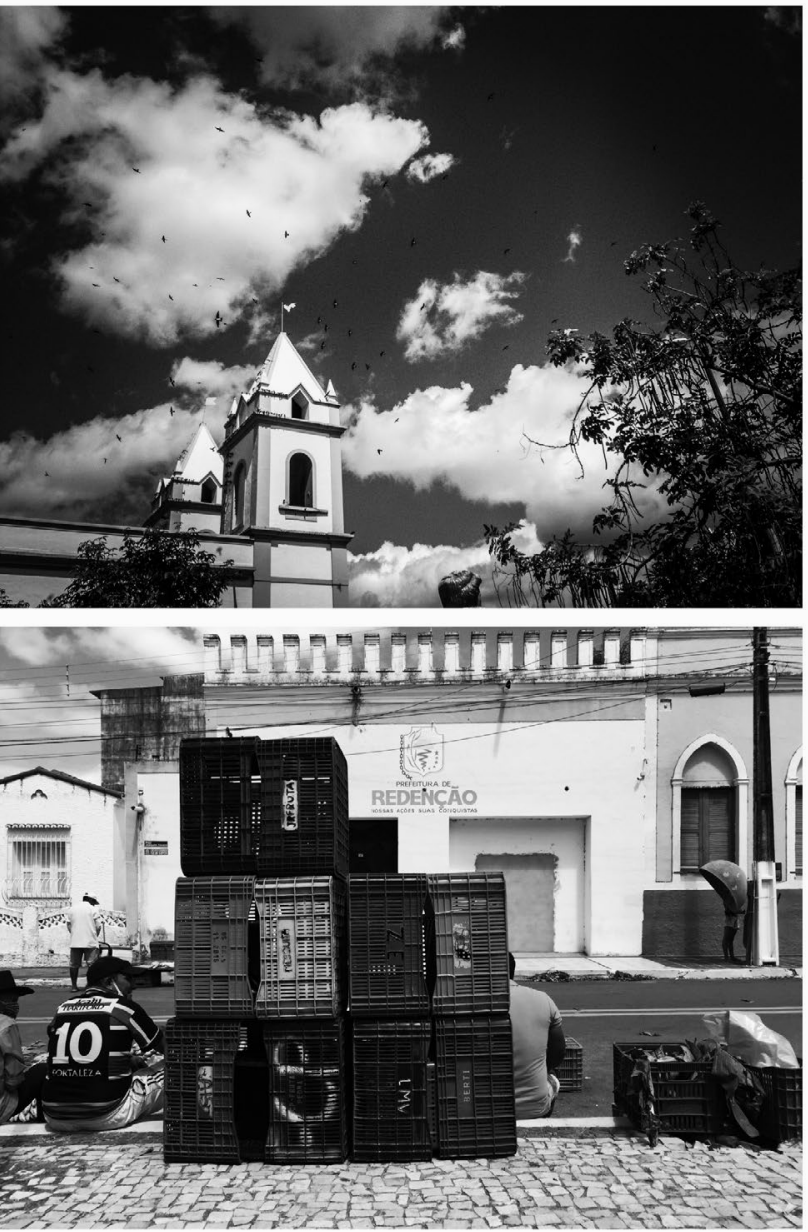


\author{
Produtos Fílmicos \\ MISSA-FEIRA \\ https://youtu.be/bJasnODiGbAA \\ A NECROPOWER \\ https://youtu.be/OPJAJMXB8KA
}

\title{
REFERÊNCIAS
}

ALMEIDA, FHO. Missa-feira de Baturité 01. jun. 2017.1 fotografia. Disponível em: https://harleyalmeida. wixsite.com/janelasdomacico?lightbox=dataItem-ki4kv22n. Acesso em: 26 novembro 2020.

ALMEIDA, FHO. Nas encruzilhadas da feira 07. jun. 2017. 2 fotografia. Disponível em: https://harleyalmeida. wixsite.com/janelasdomacico?lightbox=dataItem -ki4kv22w. Acesso em: 26 novembro 2020.

ALMEIDA, FHO. Nas encruzilhadas da feira 07. jun. 2017. 3 fotografia. Disponível em: https://harleyalmeida. wixsite.com/janelasdomacico?lightbox=dataItem-ki4kv22w. Acesso em: 26 novembro 2020.

ALMEIDA, FHO. Pau de Arara de Baturité. jun. 2017. 4 fotografia. Disponível em: https://harleyalmeida. wixsite.com/janelasdomacico?lightbox=dataItem-ki4kv22u2. Acesso em: 26 novembro 2020.

ALMEIDA, FHO. Rodoviária de Redenção 01. jun. 2017. 5 fotografia. Disponível em: https://harleyalmeida. wixsite.com/janelasdomacico?lightbox=dataItem-ki4kv22t. Acesso em: 26 novembro 2020.

ALMEIDA, FHO. Rodoviária de Redenção 05. jun. 2017. 6 fotografia. Disponível em: https://harleyalmeida. wixsite.com/janelasdomacico?lightbox=dataItem-ki4kv22v2. Acesso em: 26 novembro 2020.

ALMEIDA, FHO. Nas encruzilhadas da feira 04. jun. 2017. 7 fotografia. Disponível em: https://harleyalmeida. wixsite.com/janelasdomacico?lightbox=dataItem-ki4kv22v1. Acesso em: 26 novembro 2020.

ALMEIDA, FHO. Nas encruzilbadas da feira 06. jun. 2017. 8 fotografia. Disponível em: https://harleyalmeida. wixsite.com/janelasdomacico?lightbox=dataItem-ki4kv22v3. Acesso em: 26 novembro 2020.

ALMEIDA, FHO.Mercado de carnes 03. jun. 2017. 9 fotografia. Disponível em: https://harleyalmeida. wixsite.com/janelasdomacico?lightbox $=$ dataItem-ki4kv22×3. Acesso em: 26 novembro 2020 .

ALMEIDA, FHO. Mercado de carnes 02. jun. 2017. 10 fotografia. Disponível em: https://harleyalmeida. wixsite.com/janelasdomacico?lightbox=dataItem-ki4kv22×4. Acesso em: 26 novembro 2020.
ALMEIDA, FHO. Mercado de carnes 06. jun. 2019. 11 fotografia. Disponível em: https://harleyalmeida. wixsite.com/janelasdomacico?lightbox=dataItem-ki50h6mo. Acesso em: 26 novembro 2020.

ALMEIDA, FHO. Mercado de carnes 05. jun. 2019. 12 fotografia. Disponível em: https://harleyalmeida. wixsite.com/janelasdomacico?lightbox=dataItem-ki50h6mb. Acesso em: 26 novembro 2020.

ALMEIDA, FHO.Chão de feira 03. jun. 2017. 13 fotografia. Disponivel em: https://harleyalmeida.wixsite.com/ janelasdomacico?lightbox=dataItem-ki4kv22w3. Acesso em: 26 novembro 2020.

ALMEIDA, FHO.Cbão de feira 02. jun. 2017. 14 fotografia. Disponivel em: https:/harleyalmeida.wixsite.com/ janelasdomacico?lightbox=dataItem-ki4kv22 2 . Acesso em: 26 novembro 2020.

ALMEIDA, FHO.Chão de feira 01. jun. 2017. 15 fotografia. Disponivel em: https://harleyalmeida.wixsite.com/ janelasdomacico?lightbox=dataItem-ki4kv22w1. Acesso em: 26 novembro 2020.

ALMEIDA, FHO. Missa-feira de Baturité 03. jun. 2017.16 fotografia. Disponível em: https://harleyalmeida. wixsite.com/janelasdomacico?lightbox=dataItem-ki4kv22×1. Acesso em: 26 novembro 2020.

ALMEIDA, FHO. Missa-feira de Baturité 02. jun. 2017.17 fotografia. Disponível em: https://harleyalmeida. wixsite.com/janelasdomacico?lightbox=dataItem-ki4kv22x. Acesso em: 26 novembro 2020.

ALMEIDA, FHO.Pássaros de feira 01. jun. 2017. 18 fotografia. Disponível em: https:/harleyalmeida.wixsite.com/ janelasdomacico? lightbox=dataItem-ki4kv22w5. Acesso em: 26 novembro 2020.

ALMEIDA, FHO.Pássaros de feira 02. jun. 2017.19 fotografia. Disponível em: https:/harleyalmeida.wixsite.com/ janelasdomacico?lightbox $=$ dataItem-ki4r0pzg. Acesso em: 26 novembro 2020.

ALMEIDA, FHO. Chão de feira 04. jun. 2020. 20 fotografia. Disponível em: https://harleyalmeida.wixsite. $\mathrm{com} /$ janelasdomacico?lightbox=dataItem $-\mathrm{ki} 515 \mathrm{jw} 7$. Acesso em: 26 novembro 2020. 


\section{Tiago Morais de Freitas e Jeannette Filomeno Pouchain Ramos REMINISCÊNCIAS \\ DA ANCESTRALIDADE NA FORMAÇÃO DOCENTE: A INVENÇÃO DE UM
MUSEU COMUNITÁRIO}

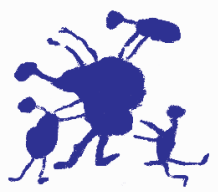

RESUMO

O presente trabalho dá continuidade às análises preliminares da invenção de um museu comunitário, enquanto prática pedagógica, que se tornou pesquisa, a partir da investigação feita pelos/as discentes sobre a biografia de seus ancestrais e autobiografia, no reconhecimento do outro e de si. O ensaio é fruto da experiência vivida no ano de 2019 entre docente e discentes da componente curricular Alfabetização, Letramento e Bilinguismo nos Países da Integração do curso de Licenciatura em Pedagogia da Universidade da Integração Internacional da Lusofonia Afro-Brasileira (UNILAB). Temos como objetivo geral analisar as memórias vividas e histórias sentidas dos ancestrais e de si, no vir-a-ser professor/a. Dentre os objetivos específicos, pretendemos revisitar os conceitos de pesquisa biográfica, autobiográfica, ancestralidade e formação docente, e (re)conhecer nas memórias e nas histórias, a partir das reminiscências, os entrecruzamentos. De natureza qualitativa, do tipo descritivo-analítico, o estudo centra-se na pesquisa biográfica e autobiográfica, com destaque para 21 narrativas de discentes. Nossos achados evidenciam a importância do resgate da ancestralidade no processo de formação docente, no reconhecimento do outro e de si, bem como demonstra que precisamos atuar mediante práticas pedagógicas que promovam uma sensibilização para uma formação mais humana, pautada na autoconstrução da identidade.

Palavras-chave

Museu Comunitário; Unilab; Ancestralidade; Identidade; Formação Docente. 


\section{INTRODUÇÃO}

O meu olhar é nítido como um girassol. Tenho o costume de andar pelas estradas. Olhando para a direita epara a esquerda. E de vez em quando olhando para trás... Eo que vejo a cada momento. É aquilo que nunca antes eu tinba visto, E eu sei dar por isso muito bem... Sei ter o pasmo essencial Que tem uma criança ao nascer. Reparasse que nascera deveras... Sinto-me nascido a cada momento. Para a eterna novidade do Mundo... (Alberto Caeiro).

Este ensaio busca apresentar a experiência vivenciada da invenção de um Museu Comunitário (MC) no ano de 2019 na Universidade da Integração Internacional da Lusofonia Afro-Brasileira (UNILAB). A proposta surgiu a partir das discussões sobre a importância do resgate das memórias e das histórias dos nossos ancestrais e de si mesmo, no processo de escolarização. Consideramos aqui também, a educação informal. Ou seja, aquela que se deu fora do ambiente escolar. Pois esta é importante mediante os diferentes processos, saberes e práticas do conhecimento adquirido da experiência de vida.

Durante um semestre, no decorrer do desenvolvimento das leituras, encontros e atividades da componente curricular Alfabetização, Letramento e Bilinguismo nos Países da Integração do curso de licenciatura em Pedagogia da UNILAB, docente e discentes, perceberam que resgatar os afetos, as experiências, saberes, práticas, memórias e histórias do outro e de si, era necessário para que a produção do conhecimento não fosse apenas transmissão de conteúdos na relação de ensino/ aprendizagem. Nesse sentido, questionamos de que forma o resgate da ancestralidade a partir da pesquisa biográfica e autobiográfica pode contribuir na formação docente? Seria esta uma prática pedagógica descolonizadora?

$\mathrm{O} \mathrm{MC}$ se tornou prática pedagógica inovadora que saiu da sala de aula para ocupar os corredores do Campus da Liberdade, com a I exposição itinerante intitulada resgate histórico dos processos de alfabetização, letramento e bilinguismo do Museu Comunitário Memórias Vividas, Histórias Sentidas nas Américas e Africas. O presente trabalho dá continuidade às análises preliminares sistematizadas por Freitas, Ramos e Costa (2020), que versam sobre a memória vivida, a história sentida e a experiência na sala de aula, enquanto que este enfatiza os entrecruzamentos na formação docente, ancestralidade e da biografia.

Neste estudo, temos como objetivo geral analisar as memórias vividas e histórias sentidas dos ancestrais e de si, no vir-a-ser professor/a. Dentre os objetivos específicos, pretendemos revisitar os conceitos de pesquisa biográfica, autobiográfica, ancestralidade e formação docente, e (re)conhecer nas memórias e nas histórias, a partir das reminiscências, os entrecruzamentos. 
De natureza qualitativa, do tipo descritivo-analítico, o estudo centra-se na pesquisa biográfica e autobiográfica (BACH JUNIOR, 2019; ABRAHÃO, 2003), dentre outros/as. Nessa perspectiva, o processo de construção do conhecimento depende muito da "[...] profundidade da relação estabelecida com o objeto do conhecimento. $\mathrm{O}$ objeto em questão, a biografia humana, requer um aprimoramento da percepção" (BACH JUNIOR, 2019, p.246). Para Moita (apud ABRAHÃO, 2003, p.81), é " [...] a metodologia com potencialidades de diálogo entre o individual e o sociocultural, pois põe em evidência o modo como cada pessoa mobiliza seus conhecimentos, os seus valores, as suas energias, para ir dando forma à sua identidade, num diálogo com os seus contextos".

Com isso, partimos do pressuposto que os/as discentes ao levantarem suas próprias narrativas, investigar e resgatar sua ancestralidade e dos ancestrais, potencializam seu processo formativo, tanto do ponto de vista da prática pedagógica, quanto da dimensão do reconhecimento do outro e de si na autoconstrução da identidade (BACH JUNIOR, 2019).

Neste estudo, além da introdução, organizamos nossa exposição da temática em três partes. Em primeiro lugar, revisitamos a literatura acerca da pesquisa biográfica e autobiográfica, ancestralidade e formação docente (NÓVOA, 1992; LARROSA, 2002; FAZENDA, 2011; OLIVEIRA, 2009; OLIVEIRA, 2012; IZA, 2014; BRANDÃO, 2017; BEDOYA, 2020), dentre outros. Em seguida, reestruturamos a experiência da invenção do Museu Comunitário Memórias Vividas, Histórias Sentidas nas Américas e Africas, analisando as 21 narrativas ${ }^{1}$ biográficas e autobiográficas dos/as discentes, que versam sobre suas memórias e histórias, desvelando o pasmo essencial das re-descobertas com as experiências ancestrais no processo de escolarização.

\section{FORMAÇÃO DOCENTE, TRABALHO AUTOBIOGRÁFICO E BIOGRÁFICO}

A escrita é uma coisa, e o saber, outra. A escrita é a fotografia do saber, mas não o saber em si.

Osaber é uma luz que existe no homem. A berança de tudo aquilo que nossos ancestrais vieram a conbecer e que se encontra latente em tudo o que nos transmitiram, assim como o baobá já existe em potencial em sua semente

(Tierno Bokar).

\footnotetext{
${ }^{1} \mathrm{O}$ corpo de discentes da turma de Pedagogia, era formada de brasileiros (a) de diferentes regiões do estado do Ceará, a citar, Pentecoste, Pacatuba, Quixadá e demais cidades da Região do Maciço de Baturité, bem como, africanos (a) de nacionalidade Guineense.
} 
A produção do conhecimento nas universidades ainda tende a seguir a lógica hegemônica de construção das narrativas científicas, pautadas numa perspectiva eurocêntrica, ou seja, que valorizam os conhecimentos produzidos no Norte Global (GROSFOGUEL, 2016). Nessa relação, não significa que na produção dos conhecimentos Sul-Sul (Brasil e Países Africanos da Lusofonia) - Cá e Acolá - no caso da UNILAB, os conhecimentos ditos "universais" sejam esquecidos. Pelo contrário, são questionados do ponto de vista epistemológico, metodológico e geopolítico, e quando necessário, desconstruídos para se tornarem algo novo.

Consoante as diretrizes da UNILAB que integra os países da lusofonia, consensuamos com a Oliveira, Ramos e Okoudowa (2013, p.16) que "O Cá é o Brasil, as Américas, que por si, é multicultural. São muitos Brasis numa única nação, numa única república de dimensões continentais". O "Acolá [...] refere-se tanto aos falantes da língua portuguesa da outra margem do Atlântico como de Timor-Leste. No que diz respeito ao continente africano, trata-se de um espaço formado por 54 países de línguas, etnias e culturas diferentes" (2013, p. 17). Desse modo, daremos ênfase ao uso do Cá e Acolá para se referir aos países que compõem a universidade, são eles: Brasil, Timor Leste, Angola, Moçambique, Guiné Bissau, São Tomé e Príncipe, Cabo Verde e Portugal. Assim, propondo fortalecer a política de cooperação internacional e a interiorização do ensino superior público (UNILAB, 2010).

Numa perspectiva descentrada do pensamento europeu, a formação acadêmica do curso de Pedagogia da UNILAB adota proposta pedagógica afrocentrada. Molefi kete Asante (2009, p.93), idealizador desse paradigma, afirma que, "[...] a afrocentricidade é um tipo de pensamento, prática e perspectiva que percebe os africanos como sujeitos e agentes de fenômenos atuando sobre sua própria imagem cultural e de acordo com seus próprios interesses humanos". E complementa,

[...] no interior da proposta afrocentrada não há sistemas fechados, ou seja, não existem ideias vistas como absolutamente fora dos limites da discussão e do debate. Assim, o emprego da afrocentricidade na análise ou na crítica abre caminho para o exame de todos os sistemas relacionados ao mundo africano (ASANTE, 2009, p.95).

Nesse cenário educacional da formação docente descentrada, a proposta da prática pedagógica da invenção do $\mathrm{MC}$, a partir da componente Alfabetização, Letramento e Bilinguismo nos Países da Integração, atende às diretrizes da UNILAB e do Projeto Pedagógico Curricular - $\mathrm{PPC}^{2}$. Além do compromisso com a formação qualificada de professores, pautou-se também a descolonização curricular.

\footnotetext{
${ }^{2}$ A componente obrigatória é ofertada semestralmente, com carga horária de 90 horas, sendo 15 horas de atividades práticas e 15 horas de extensão universitária (BRASIL, 2016).
} 
[...] a formação em pedagogia será responsável pela construção do conhecimento descentrada dos saberes europeus. Quando nos denominamos afrocentrados nos caracterizamos como um curso que pretende partir em primeiro lugar dos conhecimentos em educação elaborados ao menos nos países da integração Unilab em África (uma vez que não há como contemplar os saberes de todo o continente). Em segundo lugar priorizamos os conhecimentos em educação pertinentes ao universo diaspórico negro, com ênfase no Brasil. Em terceira instância pretendemos contemplar os saberes ditos "clássicos ou universais" elaborados pelo pensamento educacional europeu (BRASIL, 2016, pp.55-56).

Para Gomes (2012, p.105), a descolonização dos currículos “[...] implica conflito, confronto, negociações e produz algo novo. Ela se insere em outros processos de descolonização maiores e mais profundos, ou seja, do poder e do saber".

Diferentes concepções de educaçôes foram partilhadas, desde a experiência de pais, avós e familiares até dos/as discentes. O corpo estudantil da turma de Pedagogia, entre nacionais e internacionais de diferentes regiões, em espaços e tempos históricos variados, evidenciou que "[...] não há uma forma única nem um único modelo de educação; a escola não é o único lugar onde ela acontece e talvez nem seja o melhor; o ensino escolar não é a sua única prática e o professor profissional não é o seu único praticante" (BRANDÃO, 2017, p.09).

Esta prática pedagógica descolonizadora de resgate ancestral contribui na autotransformação da identidade (BACH JUNIOR, 2019) do vir-a-ser professor/a, pois a educação, como um fenômeno social, está em nossas vidas nas dimensões políticas, econômicas, culturais, relacionais e determinada por valores socialmente construídos em complexos contextos sociais. A educação escolar no Brasil, considerada fenômeno universal, é direito de todas e todos (BRASIL, 1998).

Isto posto, faz-se necessário pensar as diferentes concepções de educaçôes na busca e afirmação do sujeito como produtor de conhecimento, seja nas experiências, vivências, saberes e práticas. É possível resgatar a ancestralidade, conhecer a si mesmo e o outro, nesse processo de autotransformação da identidade. O projeto educativo afrorreferenciado é um caminho em potencial para a afirmação de sujeitos, antes considerados e colocados como inferiores, nesse cenário, africanos e afro-brasileiros. Esta prática pode explicitar o que antes estava implícito, pode re-conhecer o que antes estava latente, pulsando.

Nesse processo de re-descobertas a partir de experiências ancestrais, o trabalho biográfico se dá quando o indivíduo investiga a sua própria experiência de vida. Para Bach Junior (2019, p.234), "Aprender com o destino implica numa conexão com múltiplas dimensões (reminiscências, sensações, sentimentos, afetos, desejos, valores, expectativas...) conectadas ao âmbito social, cultural, histórico, psíquico, educacional, econômico, etc". É necessário inferir também, que "O trabalho biográ- 
fico não deveria ser confundido com mera abordagem sobre histórias de vida, mas como processo intensificado de aprendizado tendo por base o estudo do destino humano" (BACH JUNIOR, 2019, p.241).

A biografia humana se distingue de acordo com cada filosofia de vida. Contudo, ao nos orientarmos pelo princípio cronológico sequencial evolutivo da vida, o processo em síntese envolve nascimento, infância, adolescência, vida adulta, velhice, e por fim, como diria Bach Junior (2019) a tesoura do futuro, a morte. Nesse ponto, os/as sujeitos/as ao resgatarem suas reminiscências de um passado que é presente, de um presente que virá a ser futuro-passado, antes da ação da tesoura, eles/elas são capazes de contar/narrar sua própria experiência de vida, singulares.

A escolha da pesquisa autobiográfica permitiu que os/as discentes narrassem a si mesmos, seus caminhos e escolhas, e se justifica, pois, de acordo com Abrahão (2003, p.80):

A pesquisa autobiográfica - Histórias de Vida, Biografias, Autobiografias, Memórias - não obstante se utilize de diversas fontes, tais como narrativas, história oral, fotos, vídeos, filmes, diários, documentos em geral, reconhece-se dependente da memória. Esta é a componente essencial na característica do(a) narrador(a) com que o pesquisador trabalha para poder (re) construir elementos de análise que possam auxiliá-lo na compreensão de determinado objeto de estudo.

Nas narrativas coletadas através das entrevistas não estruturadas realizadas com pais, avós e familiares e a escrita autobiográfica no resgate de sua história de vida, a relação passado-presente-futuro permite desvelar as diferentes educações experienciadas e como as subjetividades se entrecruzam. Neste, também é possível a autotransformação da identidade docente, mediante diálogo entre o individual e o sociocultural.

No processo de formação docente, consoante Fazenda (2001, p.226), significa "O reconhecimento das trajetórias próprias dos homens e das mulheres, bem como exige a contextualização histórica dessas trajetórias, assumindo a provisoriedade de propostas de formação de determinadas sociedades". Nesse sentido, a formação nos permite desenvolver uma profissionalização, uma maturidade pessoal e profissional a partir da área de atuação. Capacita nosso potencial reflexivo, bem como amplia nossas percepções dos conteúdos culturais (FAZENDA, 2001). Uma vez inserido na carreira de professorar, o ato de estudar se configura como uma ação político-pedagógica-educativa, ou seja, assumimos um compromisso social pela transformação dos sujeitos (FREIRE, 2014). Complementar e consoante a isso,

A formação deve estimular uma perspectiva crítico-reflexiva, que forneça aos professores os meios de um pensamento autónomo e que facilite as 
dinâmicas de auto-formação participada. Estar em formação implica um investimento pessoal, um trabalho livre e criativo sobre os percursos e os projectos próprios, com vista à construção de uma identidade, que é também uma identidade profissional (NÓVOA, 1992, p.13).

A identidade e os saberes docentes são construídos a partir dos valores e atitudes partilhados em uma determinada cultura (IZA, et al. 2014). Um dos métodos para esse resgate ancestral é a própria história de vida dos indivíduos. Essa pode se caracterizar como uma prática pedagógica potencializadora no processo de formação docente, mas também, na relação de ensino-aprendizagem. No passo em que professores e educandos passam a reconhecer o outro e a si mesmo, respeitam-se mutuamente de maneira mais empática e amorosa. Um processo de formação, construção e compartilhamento do conhecimento de forma horizontalizada.

Importa destacar, que cada pessoa é, sobretudo, atravessada por elementos culturais, sejam eles de natureza familiar, grupos sociais que frequenta, outras culturas, concepções políticas, religiosas, etc. E cada um deles desempenha um papel singular e subjetivo no indivíduo de modo a elaborar/modificar/construir a identidade docente (IZA, et al. 2014).

É sobre recontar a experiência da invenção do $M C$, perceber esses diferentes elementos supracitados por meio do trabalho autobiográfico e biográfico na formação docente, que nos ocuparemos agora. Pretendemos evidenciar as narrativas, a fim de destacar a importância do processo vivido de modo intersubjetivo, bem como reafirmar que "O saber é uma luz que existe no homem. A herança de tudo aquilo que nossos ancestrais vieram a conhecer e que se encontra latente em tudo o que nos transmitiram [...]” (BOKAR apud HAMPÂTÉ BÂ, 2003, pp. 175-176).

\title{
(RE)CONTANDO A INVENÇÃO DO MUSEU COMUNITÁRIO: REMINISCÊNCIAS ANCESTRAIS NA FORMAÇÃO DOCENTE
}

\begin{abstract}
[...] o ser bumano não éuma unidade monolítica, limitada a seu corpo físico, mas sim um ser complexo babitado por uma multiplicidade em movimentopermanente. Ele não se trata, portanto, de um ser estático, ou concluído. A pessoa bumana, como a semente, evolui a partir de um capital primeiro, que éo seu própriopotencial e que vai se desenvolvendo ao longo da fase ascendente de sua vida, em função do terreno e das circunstâncias encontradas. (Hampaté Bâ, 1981, p. 3).
\end{abstract}

A experiência do MC possibilitou que o trabalho fosse realizado contando com participação coletiva no desenvolvimento da construção do projeto, coleta dos ma- 
teriais para a I exposição ${ }^{3}$ e das narrativas4, partilha dos relatos em sala de aula das biografias e autobiografias, trocas de afetividades, e com isso, consideramos este estudo de caráter prático, coletivo, educativo, artístico e com função social comunitária. De acordo com Larrosa (2002) a experiência é que nos dá sentido, logo pesquisar o que conhecemos/vivemos nos dá sentido, motivação, prazer.

O museu comunitário pode ser considerado como um espaço que trata das reminiscências do passado partilhadas no presente (VIEIRA, 2017). Nesse sentido, cada discente ao buscar resgatar suas histórias e memórias e dos pares, nem sempre essas experiências foram lembradas por completo, pois nesse processo existe também o esquecimento, sendo assim, reminiscências. Para ilustrar, a discente Ferreira (2019), destaca que "No geral, meus pais não lembram muito sobre o contato com a escola e com ainda mais dificuldade conseguem lembrar de forma ordenada. Lembram como se conta um sonho, sem saber se realmente aconteceu ou não" (FREITAS, et al, 2020).

Para Vieira (2017, p.142) “[...] os museus exercem um papel fundamental como ponto agregador da memória, em seu aspecto material, simbólico e funcional, como espaços dedicados à compreensão do esquecimento, em sua dinâmica com a experiência coletiva". Em seguida, apresentamos duas imagens da vivência pedagógica:

Os registros fotográficos5, como fonte de dados, nos dão base para (re)contar a experiência vivida. A exposição foi construída de forma interativa e afetiva, tendo em vista que a exposição proporcionou o toque, a criação e reorganização dos espaços por 67 pessoas da comunidade acadêmica e comunitária. Ambas as imagens permitem ter uma dimensão vivencial da invenção do $M C$, enquanto prática pedagógica.

A imagem 1 demonstra um momento de troca de aprendizagens entre docente e discentes durante a realização da atividade pensada, construída e executada pela turma composta por 21 discentes. No diálogo Cá e Acolá, a imagem 2 apresenta o

\footnotetext{
${ }^{3}$ Como fonte de análise e materiais para a exposição, tivemos como objetivo geral "Proporcionar conhecimentos históricos sobre as memórias, as histórias, os afetos e os saberes vivenciados e partilhados nas comunidades que fazem parte da cooperação solidária Sul-Sul” (FREITAS, et al, 2020, p.4). Dito isso, "No diálogo cá e acolá das vivências da escolarização foram coletados materiais, a citar livros, cadernos, cadernetas, fotografias, materiais didáticos, maquinários, dentre outros” (FREITAS, et al, 2020, p.5).

${ }^{4}$ Cada discente no ato da invenção do museu, assinou a carta de apresentação do projeto, o termo de compromisso do projeto e os termos de responsabilização de coleta dos materiais para a realização da prática pedagógica.

${ }^{5}$ Toda essa experiência de invenção comunitária está sistematizada no trabalho que consta nas referências deste texto. Buscar por: (FREITAS; RAMOS; COSTA, 2020).
} 
trabalho de pesquisa online realizado sobre os países da integração. Discentes consultaram e apresentaram em grupo, sobre a cultura, costumes, sistema educacional, política, levando em conta o elo com as temáticas discutidas em sala de aula sobre o processo de alfabetização. É possível dizer ainda que conseguimos realizar uma ressignificação dos materiais didáticos como o uso do data show em sala de aula.

A ênfase ao analisar as memórias vividas e histórias sentidas dos ancestrais e de si, a partir da Filosofia da Ancestralidade, no processo de formação docente revelou que:

$\mathrm{Na}$ construção de nossa identidade somos permeados por memórias que impulsionam o vir-a-ser. As memórias tornam-se vivas, no passado que hoje é presente, ao resgatar as experiências vividas em outro tempo e permeiam o aqui e agora. As histórias sentidas partem das percepções sutis, impressões e das experiências sensoriais reminiscentes do passado que é presente (FREITAS, et al, 2020, p.16).

Esta prática pedagógica de inventar um MC fomentou “[...] o resgate histórico da ancestralidade de cada um/uma, a formação docente e a atuação em espaços não-escolares" (FREITAS, et al, 2020, p.16).

Filósofos e estudiosos da ancestralidade (HAMPÂTÉ BÂ, 2003; OLIVEIRA, 2009; OLIVEIRA, 2012) transcendem a crença limitante desta com relação à parentalidade e à consanguinidade. A ancestralidade é aqui entendida nesta acepção ampliada, de modo que os discentes também tiveram a liberdade de relatar as experiências vividas por pessoas que partilharam com ele, ela, e que tem sentido para além da consanguinidade. Nesse sentido, a ancestralidade, "Tem como desafio a construção de mundos. Tem como horizonte, a crítica da filosofia dogmaticamente universalizante e como ponto de partida a filosofia do contexto. [...]. A ancestralidade, aqui, é uma categoria analítica que contribuiu para a produção de sentidos e para a experiência ética”. (OLIVEIRA, 2012, p.30).

Fruto do agora, a ancestralidade ressignifica o tempo do ontem. Experiência do passado ela atualiza o presente e desdenha do futuro, pois não há futuro no mundo da experiência. A cosmovisão africana é, então, a epistemologia dessa ontologia que é a ancestralidade (OLIVEIRA, 2012, p.40).

O trabalho autobiográfico e biográfico na formação docente possibilitou que os/as discentes revisitassem suas memórias, suas histórias e dos ancestrais. Durante o processo formativo, é necessário que a todo instante estejamos em busca de conhecer as coisas para reinventar e/ou ressignificar nossas práticas educativas. Intensificar o aprendizado, significa desse ponto de vista, permitir-se se reconhecer, resgatar a ancestralidade familiar, educacional, de vida! Dessa forma, as experiências de vida subjetivas se entrecruzam, por exemplo, em uma sala de aula ou fora dela, como no MC. 
Trabalhar com narrativas não é simplesmente recolher objetos ou condutas diferentes, em contextos narrativos diversos, mas, sim, participar na elaboração de uma memória que quer transmitir-se a partir da demanda de um investigador. Por isso, o estudo autobiográfico é uma construção da qual participa o próprio investigador [...] (ABRAHÃO, 2003, p.85).

É interessante aqui inferir e reafirmar o projeto educacional da UNILAB e do movimento de descolonização curricular proposto pelo curso de pedagogia. Ao perceber as diferentes narrativas, as reminiscências se entrecruzam a partir de histórias de vida, processos escolares, memórias vividas, histórias sentidas, condições sócio-econômicas, etc. A universidade por ser interiorizada passou a atender a demanda da população da região do Maciço de Baturité e outros interiores do estado do Ceará próximos, como por exemplo, Pentecoste.

Nesse sentido, o corpo de estudantes, principalmente, é formado de indivíduos de origem popular, procedentes da região urbana e rural, filhos de agricultores, famílias de baixa renda, pequenos comerciantes, estrangeiros vindos dos países da lusofonia africana, dentre outros marcadores econômicos e sociais considerados à margem da sociedade, ou seja, periferia (BEDOYA, 2020).

A ideia de memórias vividas, significa buscar na experiência vivida do passado as memórias que hoje ainda permeiam na lembrança em um outro tempo, atravessamentos e afetos, dito de outro modo, algo que nos marcou. As lembranças vêm à tona por vezes como reminiscências sem saber ao certo o que se viveu. Entretanto, fazem parte da construção da identidade profissional, já que foram vividas pelo educador em formação. Na narrativa, a discente menciona que:

O que mais me recordo tem a ver com artes. As tarefas para colorir, os textos que a professora de português da quarta série lia para a turma. Lembro do título e parte de um até hoje. Se chama "fada azul" e conta a história de uma fada que vem aos sonhos da criança e lhe conta para aproveitar bem seus anos, que tempo de criança é tempo de crescer, de ter tempo para o mundo ver (FERREIRA, 2019).

A prática artística seja do desenho, da contação de histórias, a pintura, como também das tarefas de colorir, os textos lidos, foram as memórias da discente em seu processo de escolarização. Percebam que essa lembrança é do período da $4^{\circ}$ série, a discente tinha 9 anos de idade aproximadamente. O texto "fada azul" mencionado significou um ensinamento profundo. Na universidade, a discente foi capaz de resgatar em suas reminiscências algo de anos atrás. Um passado-presente!

As diretrizes e normas do sistema educacional por vezes não leva em consideração diferentes saberes que são construídos nas vivências cotidianas das pessoas. A produção do conhecimento, sobretudo no âmbito das universidades, considera como 
importante aquele da racionalidade científica, colocado como sobreposto aos saberes tradicionais, sejam eles, herdados de geração em geração, de práticas ancestrais, tradições culturais de determinadas comunidades, conhecimentos domésticos, enfim.

Alguns fatores, tais como, condição econômica, social, familiar, geográfica (relação rural e urbano), dentre outros, muitas vezes impedem que os/as sujeitos/ as cheguem em determinados espaços. Tais como, a universidade, o mercado de trabalho e até mesmo, a escola. Morais (2019) ao resgatar a biografia de sua mãe, reafirma esse pensamento demonstrando que,

Nunca podemos desconsiderar os conhecimentos tradicionais e de vida dessas pessoas como minha mãe. Apesar de não ter o conhecimento técnico das coisas, possui diversos conhecimentos tradicionais herdados de suas vivências e experiências durante a vida até hoje. Ela sabe ler algumas coisas e escreve o nome. $\mathrm{O}$ estudo, em seu pensamento, era uma ascensão, mas os cuidados com a família, na figura de mulher, parece que a forçaram a seguir um caminho diferente.

A dificuldade de acesso à escolarização de avós, pais e familiares, em geral, residentes em contexto rural e que desenvolviam atividades de trabalho, a partir da agricultura, foi um dos fatores apresentados por discentes (SILVA, 2019; MORAIS, 2019; MARIA DA SILVA, 2019; SOUSA DA SILVA, 2019). Silva (2019), ao dissertar sobre a biografia de seus avós identificou que "Ambos de famílias pobres, trabalhavam como agricultores durante toda sua infância e vida adulta, sendo estes sobreviventes de um contexto social muito empobrecido". Sistematizadas as narrativas, de acordo com Freitas (et al, 2020, p.12),

A análise dos relatos desvela um cenário intergeracional correspondente no Brasil e em Guiné Bissau, pois, no contexto histórico familiar avós e pais não tiveram a oportunidade de ingressar na educação escolar básica e, quando ingressaram, a maioria desistiu por ter que trabalhar na roça na agricultura de subsistência, ou seja, trabalho infantil. Morais afirma, a partir do relato de sua mãe, que "Não era possível estudar com fome". Há ainda outros fatores citados como mortalidade infantil, cuidar da casa, cuidar dos irmãos ou sobrinhos, não haver escolas com oferta de seriação a partir da $4^{a}$ série para continuidade nos estudos.

Em outra narrativa, que abrange a biografia dos familiares e sua autobiografia, Sousa da Silva (2019) evidencia a problemática da falta de acesso à escola, condição econômica desfavorável, mas que, contudo, conseguiu ingressar na universidade. Relata que: 
A educação escolar na minha família sempre foi desejada, mas isso não garantiu que conseguíssemos cumprir nossos sonhos. Sou a primeira a ingressar em uma universidade e ainda por cima pública. Minha avó e meu avô maternos são analfabetos. Aprenderam apenas a escrever seus nomes quando já idosos, quando crianças não havia escolas nem no local onde habitavam nem nas proximidades, o que havia era uma mulher que dava aulas em sua casa, para os filhos dos pais que tinham condições de pagar (SOUSA DA SILVA, 2019).

Paralelo às condições sócio-econômicas, bem como geográficas, a forma e as práticas educativas, o modo como ensinar, passaram por muitas transformações estruturais em diferentes tempos. Antigamente, considerando o tempo/idade de cada sujeito, nossos avós e pais vivenciaram processos escolares punitivos. Os castigos até certo tempo faziam parte do cotidiano da sala de aula com a finalidade de punir aquele/a estudante que fugisse da normalidade. Nesse sentido, Alves (2019) evidenciou que sua avó "[...] lembra de alguns castigos, como caroço de milho e palmatória utilizada para disciplinar alunos [...]". Ferreira (2019) ao buscar resgatar a biografia do familiar, menciona que segundo seu pai "[...] as punições consistiam em deixar as crianças de joelho ao lado da professora. Pelo que lembra todo o ensino foi realizado por professoras, mas não apenas uma como aconteceu com minha mãe". Ao tratar da mãe, o ensino era ministrado somente por uma professora, que morava próximo a sua casa.

Os materiais didáticos usados no processo de escolarização do tempo passado são muito diferentes do tempo presente. A formação de professores, as práticas educativas e o sistema de ensino escolar mudou. A era atual é tecnológica e exige de todos nesse processo, capacidades múltiplas. Contudo, por volta de 1970, o processo de alfabetização era realizado através das cartilhas do ABC. Oliveira (2019) buscou no relato de sua avó identificar como ocorreu esse processo. Identificou que "Só se passava para a cartilha, depois de "aprender" toda a carta de ABC, ou seja, passar para a cartilha, significava um grande avanço para os estudantes".

Como demonstrado por Brandão (2017) a educação escolar não é o único modelo e talvez nem seja o ideal. Apesar de sabermos das dificuldades e desafios do atual sistema de educação nos Países da Lusofonia, sabemos da importância do processo de escolarização formal, da leitura e escrita, para inserção social, cultural e econômica dos/as sujeitos/as no modelo de sociedade vigente. Sousa da Silva (2019), traz uma reflexão importante nesse sentido quando narra: "Meu avô paterno frequentava uma mulher que dava aulas em sua própria casa, ela não tinha um material pedagógico, ensinava apenas a escrever o nome, conhecer as letras e ler pequenas palavras". Nesse relato, podemos perceber que apesar do ensino das primeiras letras não ter acontecido no ambiente escolar, este não deixou de ser ensino. Pelo contrário, permitiu que a prática de fazer o próprio nome, conhecer às letras e pequenas palavras colaborasse com o processo educacional do ancestral da discente. 
A ancestralidade tem como característica um contínuo processo de ligação permanente. Estamos conectados com as gerações que nos antecederam. E nós, como constituintes do tempo presente, futuramente, seremos os ancestrais das gerações que irão nos suceder. Alves (2019), ao buscar a narrativa de sua bisavó de 80 anos, põe em evidência uma problemática vivenciada por muitos avós, pais, familiares, etc, que durante muito tempo não tiveram acesso a programas suplementares capazes de propiciar o acesso e permanência na escola, bem como a continuidade dos estudos, a citar, alimentação, moradia, transporte, material didático, dentre outros. Para sua bisavó, ainda de acordo com Alves (2019) "A maior dificuldade que ela fala é a questão de local mesmo, por conta da distância, no meio da conversa ela solta "é.... minha fia, era pra eu ser inteligente, sabia toda a tabuada, as quatro operaçóes, mas não terminei porque nấo tinba canto". (grifo nossos).

Sabemos que as experiências vividas que nos atravessaram durante o percurso de escolarização refletem em como construímos nossa identidade enquanto profissional da educação, em diferentes contextos e percursos pessoais. Com isso, a partir da narrativa autobiográfica do discente Pereira (2019), este reconhece que "Como futuro educador eu tenho a obrigação de seduzir o/a aluno/a ao gosto pela escola, pela leitura, pela transformação social e ser um incentivador das mais variadas formas de educar/alfabetizar, considerando as especificidades de cada estudante". Este ao abordar tais questões educativas na tentativa de "seduzir" os estudantes, reconhece a importância da escola e da leitura para a transformação dos sujeitos a partir da educação.

Assim, é importante perceber que com base no resgate da ancestralidade dos/as discentes, estes passam a reconhecer a si e ao outro, se potencializam, criam vínculos e fortalecem a luta contra o sistema opressor que padroniza mentes, corpos e processos educativos. Para Bedoya (2020, p.253), "O resgate da ancestralidade leva a compreender que o afrocentrismo, mais que uma possibilidade de conhecimento, representa um compromisso ético com a recuperação da memória/consciência da ancestralidade que foi apagada, silenciada, deturpada, embranquecida nos povos colonizados". A descolonização parte, então, de pensar a educação na perspectiva da educação afrocentrada, com base nos princípios da afrocentricidade (ASANTE, 2009).

A partir das narrativas apresentadas, é possível identificar que as reminiscências biográficas e autobiográficas do processo de escolarização e de formação docente, se entrecruzam. Tendo em vista que a maioria dos discentes é de origem humilde, popular, de baixas condições socioeconômicas, fica evidente que fatores econômicos, sociais, geográficos e políticos, são pontos que precisam ser refletidos sobre as diferentes realidades. Ao reconhecer esses diferentes pontos que se entrecruzam na construção da história de vida, conseguimos perceber que a ancestralidade é uma ligação permanente que está imbricada na nossa trajetória familiar e reflete também as nuances do processo educacional de cada um/uma que escolhe seguir a carreira da docência. 


\section{A CAMINHO DE CONCLUSÃO}

Tenbo em mim um atraso de nascença. Eu fui aparelhado para gostar de passarinhos. Tenho abundância de ser feliz por isso. Meu quintal é maior do que o mundo. Sou um apanbador de desperdícios: Amo os restos como as boas moscas. Queria que a minha voz tivesse um formato de canto. Porque eu não sou da informática: eu sou da invencionática.

Só uso a palavra para compor meus silêncios.

Manoel de Barros

Inspirados na poesia de Manoel de Barros, precisamos desvelar num contínuo movimento, o pasmo essencial das re-descobertas com as experiências ancestrais no processo de formação docente. Esse resgate das diferentes memórias vividas e histórias sentidas dos/as discentes permite inferir que para construirmos um pensamento descolonizado, dando importância às coisas desimportantes, é necessário que os/as sujeitos/as sejam protagonistas das suas próprias narrativas do que foi/é vivenciado. O museu comunitário (VIEIRA, 2017), enquanto prática pedagógica inovadora, associado a técnica de pesquisa biográfica e autobiográfica (BACH JUNIOR, 2019; ABRAHÃO, 2003), são ferramentas capazes de realizar essa produção e compartilhamento das experiências, trajetórias e histórias de vida. Como cita Barros, "Meu quintal é maior que o mundo", portanto, nossas histórias, memórias e heranças ancestrais encontram-se latentes para serem revisitadas.

Nesse processo de construção do projeto do MC, planejamento das atividades em sala de aula e realização da I exposição itinerante, podemos identificar troca de afetividades mútua no processo de formação. O sensível foi despertado como característica fundamental nas relações entre o individual e o sociocultural. É de suma importância, reconhecer as diferentes trajetórias de vida e isso foi possível através das narrativas biográficas e autobiográficas apresentadas. Confirmamos assim, que "O sujeito que analisa sua história está sempre intrinsecamente conectado ao sujeito que cria a linguagem da sua narrativa, ao sujeito que construiu a percepção e a valorização do vivido, ao sujeito que interpreta e configura sua realidade" (BACH JUNIOR, 2019, p.246).

Podemos verificar também que a aquisição do conhecimento não precisa ser burocrática, nem sofrida. O caminho possível é a reinvenção da prática pedagógica, somos da invencionática. E assim, dentre outros fatores, notamos que foi possível colaborar no processo de potencialização dos/as sujeitos/as durante a formação docente, bem como, contribuir, ainda que de maneira sutil, para a descolonização dos currículos.

Portanto, para Freitas, et al. (2020, p.29) "As experiências comunitárias promovem, sobretudo, o autoconhecimento e reconhecimento de si, ressignificando as memórias vividas e as histórias sentidas para continuação da narrativa do tornar-se 
professor alfabetizador em processo contínuo de auto-educação". Nessa construção, o contato com a própria educação escolar influencia diretamente no processo. Imaginemos as influências que tivemos de professores(as) e das instituições pelas quais estudamos em algum momento e contexto de nossas vidas. Muitas pessoas cruzaram e cruzam nosso caminho por meio de diversas relações sociais, assim, estamos constantemente em construção, ou melhor, em autoconstrução (BACH JUNIOR, 2019). Chega a ser difícil saber o produto final. A única certeza que podemos enfatizar é que aprendizagem é fruto da experiência!

\section{REFERÊNCIAS}

ABRAHÃO, Maria Helena Menna Barreto. Memória, narrativas e pesquisa autobiográfica. Revista História da Educação, v. 7, n. 14, p. 79-95, 2003.

ASANTE, Molefi kete Afrocentricidade: Notas Sobre uma Posição disciplinar. In: Afrocentricidade: Uma abordagem epistemológica inovadora. São Paulo: Selo Negro. Ed. Sankofa. 2009.

BRASIL. Constituição da República Federativa do Brasil. Bahia, Imprensa Oficial do Estado, 1988.

BRASIL. (UNILAB). Projeto Pedagógico Curricular do curso de Licenciatura em Pedagogia. Redenção. 2016.

BRASIL. (UNILAB). Diretrizes Gerais da UNILAB. 2010.

$\mathrm{BACH}$ JUNIOR, Jonas. O trabalho biográfico como fonte de aprendizado: autoeducação e fenomenologia de Goethe. Educar em Revista, v. 35, n. 74, p. 233-250, 2019.

BRANDÃO, Carlos Rodrigues. O que é educação. São Paulo: Brasiliense, 2017.

BARROS, Manoel. O apanhador de desperdícios. Disponível em: < https://www.ufrgs.br/enunciarcotidianos/2017/07/18/o-apanhador-de-desperdicios-manoel-de-barros/ < Acesso em: 15 de novembro de 2020.

BEDOYA, Luis Eduardo (Lucho) Torres. Experiência autobiográfica na formação docente: uma abordagem afrocentrada. In: Rede de colaboração educacional: a Unilab em destaque numa dimensão afrocentrada / Ivan Costa Lima, Gisela Macambira Villa-corta (orgs). - Fortaleza: Imprece, 2020. p.243-265.

FREIRE, Paulo. Pedagogia da esperança: um reencontro com a pedagogia do oprimido. Editora Paz e Terra, 2014.

FAZENDA, Ivani Catarina Arantes. Dicionário em construção: interdisciplinaridade. Cortez editora, 2001.
FREITAS, Tiago Morais; RAMOS, Jeannette Filomeno Pouchain; COSTA, Anderson Gonçalves. Memórias vividas, histórias sentidas nas Américas e Áfricas: a invenção de um Museu Comunitário. Research, Society and Development, v. 9, n. 7, p. e369974030, 2020.

GROSFOGUEL, Ramón. A estrutura do conhecimento nas universidades ocidentalizadas: racismo/sexismo epistêmico e os quatro genocídios/epistemicídios do longo século XVI. Sociedade e Estado, v. 31, n. 1, p. 25-49, 2016.

GOMES, Nilma Lino. Relações étnico-raciais, educação e descolonização dos currículos. Currículo sem fronteiras, v. 12, n. 1, p. 98-109, 2012.

HAMPÂTÉ BÂ, Amadou. Amkoullel, o menino fula. Tradução de Xina Smith de Vasconcellos, 2003.

HAMPATÉ BÂ, Amadou. A noção de pessoa na África Negra. Tradução: Luiza Silva Porto Ramos e Kelvin Ferreira Medeiros]. HAMPÂTÉ BÂ, Amadou."La notion de personneen Afrique Noire”. In: DIETERLEN, Germaine (ed.). La notion de personneen Afrique Noire. Paris: CNRS, p. 181-192, 1981.

IZA, Dijnane Fernanda Vedovatto et al. Identidade docente: as várias faces da constituição do ser professor. Revista Eletrônica de Educação, v. 8, n. 2, p. 273-292, 2014.

LARROSA, Jorge. Notas sobre a experiência e o saber de experiência. Revista Brasileira de Educação, $\mathrm{n}$. 19 , p. 20-28, 2002.

NÓVOA, António. Formação de professores e profissão docente. 1992. 
OLIVEIRA, Gledson Ribeiro; RAMOS, Jeannette Filomeno Pouchain; OKOUDOWA, Bruno. Diálogos Multiculturais: possibilidades e limites da ruptura politica e epistemológica. In: Cá e Acolá: experiências e debates multiculturais. - Fortaleza: Edições UFC. 2013.

OLIVEIRA, Eduardo. Epistemologia da ancestralidade. Entrelugares: Revista de Sociopoética e Abordagens Afins, v. 1, n. 2, 2009.
OLIVEIRA, Eduardo David de. Filosofia da ancestralidade como filosofia africana: educação e cultura afro-brasileira. Revista Sul-Americana de Filosofia e Educação, v. 18 , p. $28-47,2012$.

PESSOA, Fernando. O meu olbar énítido como um girassol. 1993.

VIEIRA, Guilherme Lopes. O museu como lugar de memória: o conceito em uma perspectiva histórica. Mosaico, v. 8, n. 12 , p. $139-162,2017$. 


\section{Lucimar Bello Frange}

\section{UM POMAR DE SONHOS, UMA PROPOSIÇÃO}

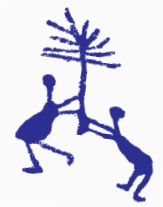

Escolha um tecido, um papel estampado ou liso. Pode ser uma toalha de mesa, um pano de prato, um papel usado. Estenda sobre uma superfície plana ou sobre o chão. Olhe as estampas, as dobras e as marcas de uso. Separe um bom tanto de pedras ou galhos secos pequenos ou pétalas de flores ou conchas miúdas ou cravos da Índia. E coloque-os numa das mãos. Com as pontas dos dedos, da outra mão, arrume esses miúdos com cuidados. Todos são mínimos de mundos. E nós, somos um mínimo da biosfera. Desenhe, com leveza, sobre as linhas observadas. Podem ser trilhas e caminhos inventados, até mesmo, nem vistos, nem imaginados. Podemos fazer juntos uns mapas de linhas que se entrecruzam, bifurcam, ficam sem começo e sem fim, linhas que se perdem. Os escravos cortavam os cabelos desenhando nas cabeças, as rotas de fuga, de um modo que as pessoas não pudessem imaginar. Esses atos, tanto os seus como os de um grupo, podem ser semelhantes às ações dos escravos. São práticas de delicadezas e sabedorias para existir, resistir e manter a vida coletiva. Olhe os desenhos, mostre para mais pessoas e converse sobre os modos de manter a vida prosseguindo em 2020. Pense nos modos de construir as escapatórias como movimentos dos seres viventes, seja uma pessoa, uma formiga, uma gota d'água, um raio de sol. Veja, perceba e sinta, com agudeza, as rotas de fugas que temos construído durante essa pandemia na qual estamos enfiados. E, no Brasil, nesse pandemônio das políticas indevidas e facínoras. Pense nas histórias que sustentam as fugas atuais e nas nossas consistências para manter Uma Vida Acesa - Coletiva! Pensemos nos modos de atuar para um mundo diverso desse tão esgotado por uma selvageria de explorações, lucros descabidos e vidas soterradas.

As pontas dos dedos e os miúdos escolhidos são mínimos de mundos vivos muitos biomas e inúmeros ecossistemas. Essa proposição é fazer sangrar as feridas colonialistas e, ao mesmo tempo, cuidar das bordas desses ferimentos realizando mini experiências de brotamentos de forças "coletivizáveis" - as que não cessam de brotar. Entre um e entre todos. 


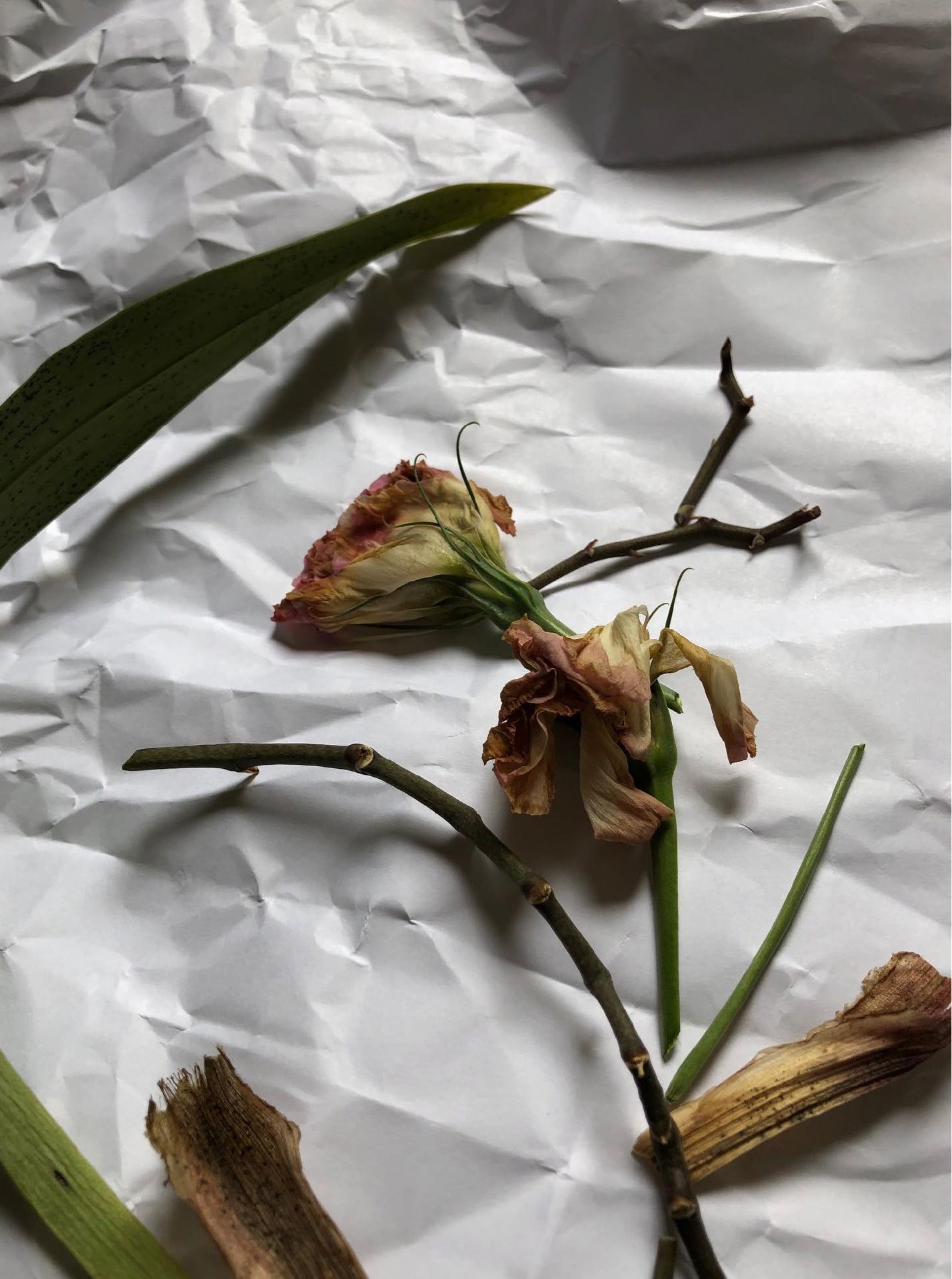




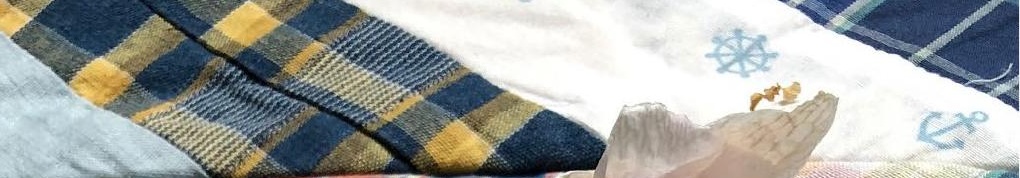

\section{,}


Um pomar de sonhos é uma proposição para sonharmos e fazer verter a liberdade de pensamento; fazer acontecer a liberdade de existir em comunidades; organizar formas de sociabilidade político-culturais-existenciais.

Existir é insistir e resistir para as re-existências!

Um Pomar de Sonhos é uma proposição para além dos desafios das inquietações da Educação Artística ou da Arte educação. Muitas são as feridas encravadas no decolonial. Muitas colonizações existem em cada pessoa e em lugares diversificados, são as marcas daquilo que nos exploram, esgotam e exaurem. As trilhas e os caminhos são fendas de entrelinhas, entrelugares e potências de criação em salas de aulas e na vida-em-processo. Considero as salas de aulas em sentido bastante ampliado: uma sala de comer, uma sala de visitas, uma sala de estar, uma sala de trocas-e-trocas chamada escola, uma sala numa comunidade em qualquer cidade, lugarejo ou cantinho do mundo. Cada lugar éo mundo (Milton Santos). O Ocidente não é uma verdade, são invenções para sistematizar mandatários e suas imposições colonialistas. As práticas decoloniais perpassam estéticas, estesias e éticas na arte e na vida. Inventar e sustentar Uma Vida é um direito desde que nascemos até morrermos. Temos muito a aprender com as etnias africanas - as rotas de fuga desenhadas nas cabeças, quer de homens, quer de mulheres, para além de "belos penteados". As rotas de fuga são mapas de atravessamentos.

Gritar, rachar, semear (Catherine Walsh), são ações a praticarmos nas Améri$\mathrm{ca}(\mathrm{s})$ Latina(s), analisando as desapropriações dos muitos povos esmagados e suas etnias. As experimentações decoloniais são práticas além do "sistema educacional". Nossa vivência, em tempos atuais, são urgências: gritar, rachar, semear, brincar, abraçar pessoas e culturas; agir inter-pessoas e inter-culturas. Criar rotas de fuga é gestar modos de conviver com as marcas que nos constituem, olhar para as fendas que ali existem e praticar ações de potências de Vida.

Um Pomar de Sonhos se propõe a desenhar as incertezas das democracias em risco e nos tempos incertos nos quais vivemos, propondo trilhas e caminhos outros, nos quais estejamos vinculados aos seres vivos no universo. Essa proposição dialoga com aspedagogias da roda, do brinquedo, do sabão, do copo cheio, do abraço (Tião Rocha). Dialoga com artistas e algumas de suas obras:

Néle Azevedo - Monumento Mínimo

Rodrigo Bueno - Ateliê Mata Adentro

Bijari - Carros Verdes

Sakir Gokcebag - Frutas geométricas

Rivane Neuenschwander - Comidas e cenários

Clarice Borian - Punhado de delicadeza

Andy Goldsworthy - As Quatro Estações

Lucimar Bello - Desenhos de Comer 

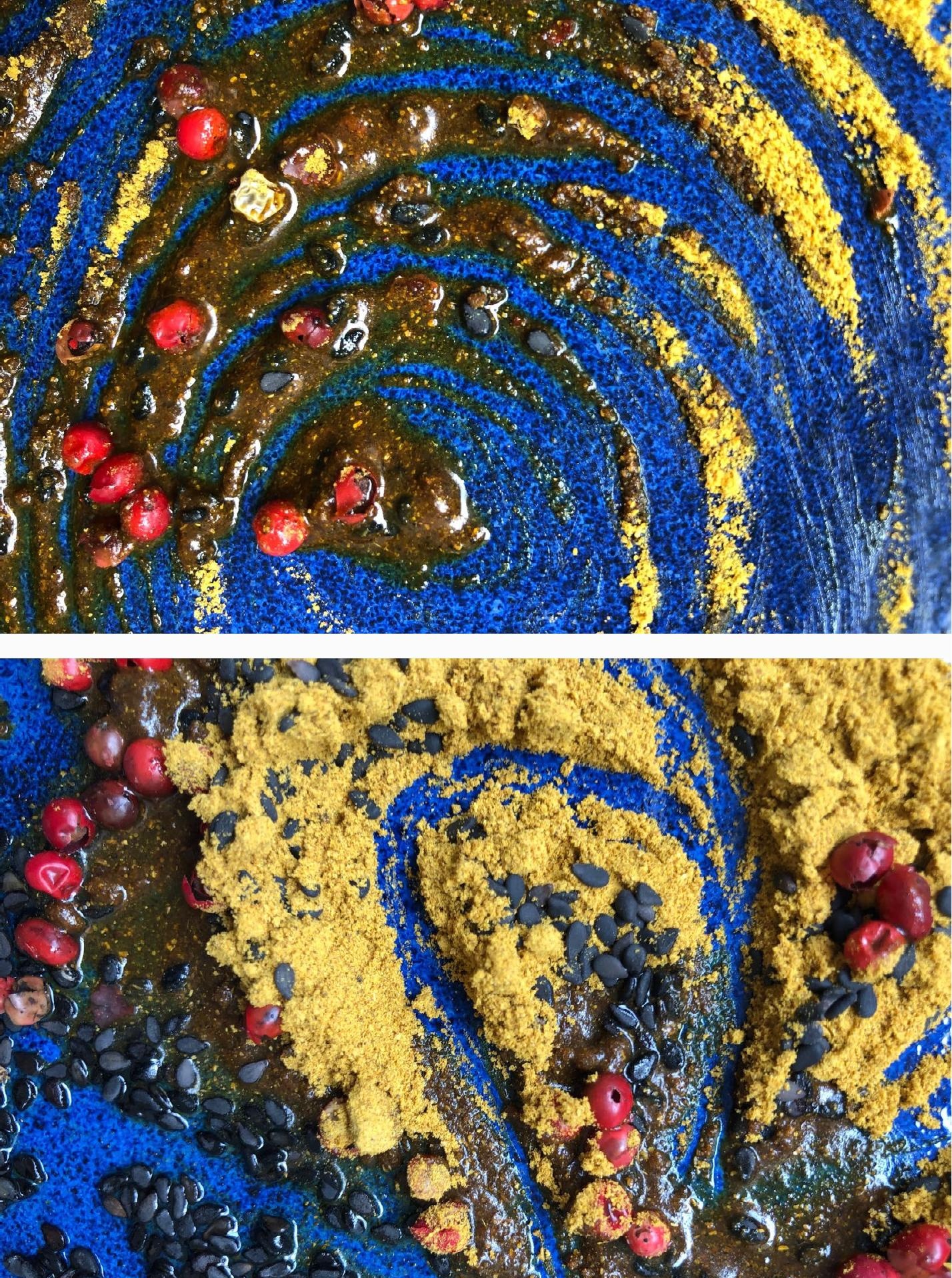


\section{REFERENNCIAS}

RANCIÈRE, Jacques. A partilha do sensivel. São Paulo, Exo, 2005.

BARBOSA, Ana Mae (org.). Arte-Educação Contemporânea. São Paulo, Cortez, 2010.

BARROS, Manoel de. Livro sobre nada. Rio de Janeiro, Alfaguarra, 2016.

JAFFE, Noemi. Livro dos começos. São Paulo, Cosac Naify, 2016.

PESSANHA, Juliano Garcia. Recusa do náo-lugar. São Paulo, Ubu, 2018.
KILOMBA, Grada. Memórias da plantação. Rio de Janeiro, Cobogó, 2019.

KRENAC, Ailton. Ideias para adiar o fim do mundo. São Paulo, Companhia das Letras, 2019.

WALSH, Catherine. "Interculturalidade e decolonialidade do poder: um pensamento e posicionamento 'outro' a partir da diferença colonial". In: Revista Eletrônica da Faculdade de Direito de Pelotas, v. 5, n. 1, Jan-Jul, pp. 06-39. 


\section{Maria Aridenise Macena Fontenelle}

\section{ENGENHARIARTE \\ RELATO DE EXPERIÊNCIA}

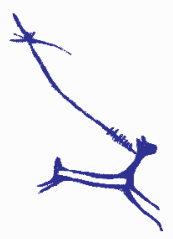

\section{CONSIDERAÇÕES INICIAIS}

A Pedagogia Waldorf, metodologia de ensino baseada em procedimentos artísticos, existe desde o ano de 1919, quando Rudolf Steiner, seu criador, fundou a primeira escola em Stuttgart na Alemanha.

Para Steiner arte é algo que atua sobre o crescimento, a saúde e o progresso do homem.

O cotidiano de uma escola Waldorf permite observar a utilização de diversos procedimentos artísticos na sala de aula durante toda a educação básica. Especialmente no período correspondente ao ensino fundamental, percebe-se que a pintura em aquarela e o uso de diversos tipos de narrativa - contos, mitos, biografias - norteiam a ação docente como base para o planejamento diário.

A pintura em aquarela é utilizada para a elaboração imagética desses conteúdos e perpassa todos eles ao longo da formação do aluno.

LANZ (1999) considera que, na vida real das classes, as experiências feitas com elementos das artes plásticas se confundem, sendo que o princípio é constituído pelo desenho de formas, antes da pintura. Explica que o desenho de formas se constituirá um assunto essencial durante várias épocas. Destaca ainda que os outros elementos não aparecem tão isoladamente, eles vivem no ensino de uma maneira geral.

Este artigo apresenta as estratégias inovadoras utilizadas pelos estudantes para apresentar o resultado da aprendizagem nas disciplinas de Tecnologia das Construções e de Gestão da Produção das Construções foram: aquarelas sobre visitas à obra realizadas e sobre gestão da construção; produção de cordel sobre canteiro de obras e planejamento de obras; uma paródia sobre construções do futuro e sobre BIM (Building Information Modelling) e uma poesia sobre Gestão da construção. Os resultados demonstraram um bom rendimento da turma para além do conhecimento técnico a ativação do sensível. 


\section{METODOLOGIA}

Tecnologia das Construções é uma disciplina do curso de Engenharia Civil que visa proporcionar aos discentes conhecimentos das etapas de execução dos serviços de uma obra de construção civil com visão dos processos, linguagem técnica e ferramentas básicas para gestão e produção de edificações.

Custos diretos e indiretos, Gestão de contratos, Tipos de planejamentos de obras, Linha de balanço, Curva S, tipos de orçamentos são os principais conteúdos da disciplina de Orçamento, Planejamento e controle de obras.

Gestão da Produção das Construções é uma disciplina eletiva do curso de Engenharia Civil. No conteúdo programático é abordado: Qualidade e Produtividade na Construção Civil; Inovação na Construção, Tecnologias da Informação e Comunicação na Construção, Norma de desempenho, Construção Enxuta.

As principais estratégias de ensino utilizadas são: Aulas expositivas com discussão de conceitos e estudos de caso; Leitura e interpretação de textos; Seminários dos alunos para apresentação de artigo científico e de estudos de caso e/ou trabalhos práticos realizados por eles e Visitas técnicas.

\section{RESULTADOS DA EXPERIÊNCIA}

\subsection{AQUARELANDO A VISITA TÉCNICA REALIZADA EM OBRAS DE CONSTRUÇÃO CIVIL}

Nas visitas técnicas procura-se observar na prática os processos construtivos estudados em sala de aula e também inovações tecnológicas utilizadas nas obras visitadas. O relatório da visita é realizado através de pintura em aquarela que é uma vivência artística praticada na pedagogia Waldorf. Além das observações das visitas técnicas os discentes também pintam síntese de conteúdo da disciplina de Gestão e Produção da Construção.

As figuras 1e 2 mostram os estudantes do curso de engenharia civil realizando a aquarela sobre síntese de conteúdo da disciplina de Gestão e Produção da Construção.

Durante a oficina de aquarela a pintura é utilizada como expressão de sentimentos e linguagem não verbal. Nesta oficina são apresentados a técnica e os materiais utilizados na mesma como: as tintas aquarelas, os pincéis, os papéis específicos para esta pintura, potes com água, para descansar os pincéis, e esponja para molhar o papel e tábua de madeira para fixar o papel molhado, antes dos participantes realizarem a pintura.

A aquarela, por exemplo, é um tipo de pintura realizada com uma tinta resultante de pigmentos de várias cores misturados, geralmente com goma arábica, e que precisa ser dissolvida em água para ser utilizada. O papel utilizado para este tipo 


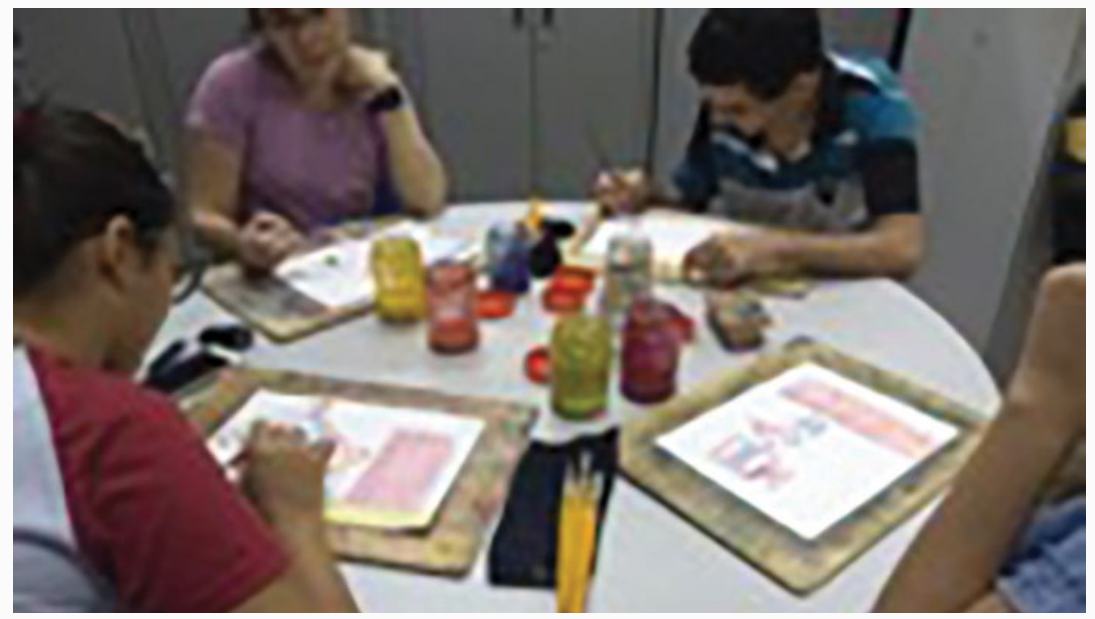

Figura 1 e 2 - Aquarela sobre da disciplina de Gestão e Produção da Construção e Tecnologia das construções. Fonte: Autoria própria (2018).

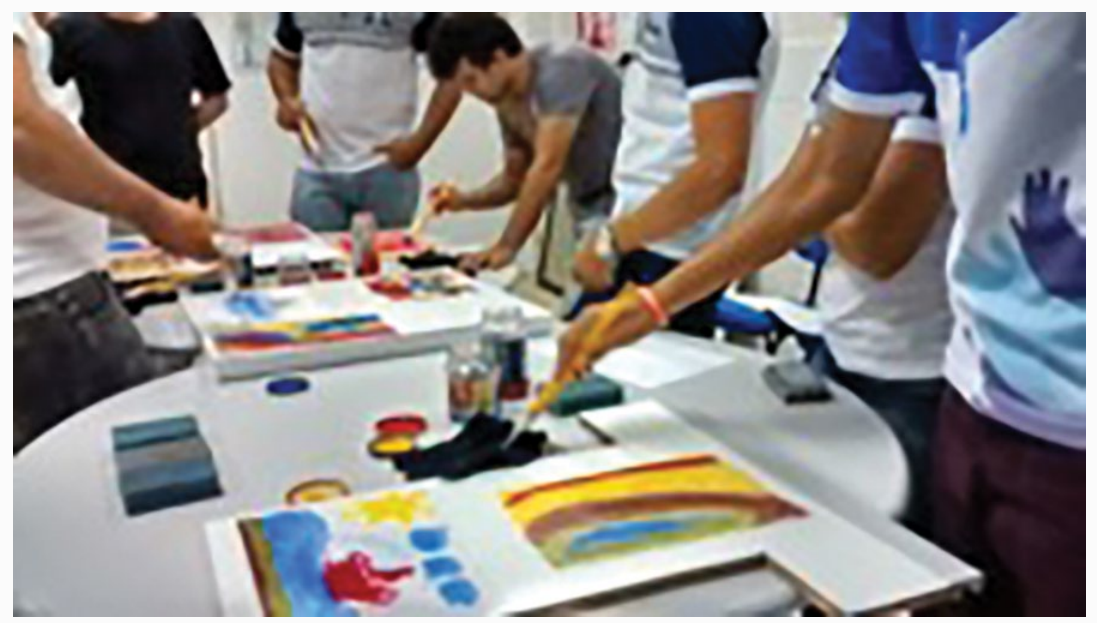


de pintura deve possuir textura e gramatura diferenciada, pois, se muito fino, pode deformar ou rasgar com a água aplicada sobre o mesmo, uma vez que a quantidade de líquido presente no papel determina a variação de tons.

\subsection{PRODUÇÃO DE CORDEL SOBRE CANTEIRO DE OBRAS}

O trabalho de produção dos cordéis contou com a observação participante, e a coleta e análise de cordéis produzidos pelos estudantes do Curso de Engenharia civil em três canteiros de obras em Mossoró-RN.

Para isso, foi necessário discutir sobre as possibilidades e desafios desta ação educativa com alunos do curso de estudantes de Engenharia, na disciplina de Tecnologia das Construções no Curso de Engenharia Civil e perceber de que maneira a literatura de cordel pode contribuir como potencializadora da aprendizagem.

A atividade proposta foi denominada "Cordeleando", sendo apresentada na disciplina de Tecnologia das Construções no Curso de Engenharia Civil. Para redação do cordel definido o tema "Condições e meio ambiente de trabalho na Construção Civil". A produção tem início com uma avaliação da Gestão e Produção nos canteiros de obras. Em seguida, os estudantes com ajuda de um dos colegas que tinha experiência com literatura de cordel, vão produzindo os versos.

Os estudantes demonstraram uma certa facilidade, sendo estratégico que estes peçam a colaboração para os seus próprios versos.

A inovação didática, com a introdução de material diferenciado que envolva aspectos culturais da região a que pertencem os alunos, cria vínculos com os costumes de sua "gente", de sua "terra", gerando, assim, uma alternativa de produção e transmissão de múltiplos conhecimentos (Nascimento, 2015; Souto et al., 2016). Além disso, ao despertar o interesse dos alunos, novos temas poderão ser trabalhados para a valorização de sua comunidade, por meio da convivência familiarizada com a cultura regional/local, articulando diferentes saberes produzidos pelos meios populares (Bressiani, 2016; Coelho, 2016; Santos, 2016)

A prática de produção compartilhada de literatura de cordel, sobre temáticas de Condições e meio ambiente de trabalho na construção civil, demonstrou ser capaz de aplicar os princípios da literatura de cordel.

A literatura de cordel é capaz de concretizar princípios universais identificados na proposta utilizada neste estudo em que se traduz habilidades e competências muito pouco valorizadas no ensino das engenharias e permitem repensar o papel da universidade como instituição cujo compromisso social tem sido reivindicado de maneira recorrente por diferentes setores da sociedade (Da Silveira et al., 2015).

A baixa oferta de escolarização ao longo do século 20 e o número alto de pessoas que não sabem ler e escrever, principalmente na zona rural de alguns estados do Nordeste, fazem com que, por exemplo, no RN, pessoas com maior grau de escolaridade utilizem o cordel como forma de transmitir conhecimento, lendo para 
seus amigos ou familiares que possuem pouco ou nenhum grau de instrução escolar. Nesse contexto, o cordel cumpre o papel social da linguagem fazendo uma ponte entre o enunciador e o enunciatário. É extremamente valioso reconhecer nele mais um meio de comunicação verbal capaz de informar, formar opiniões, questionamentos e reflexões e propiciar interação com o outro, oferecendo a oportunidade de entrar em contato com uma linguagem diferenciada que expõe a diversidade cultural (Da Silveira et al., 2015; Alves, 2016; Souto et al., 2016; Castro, 2017).

$\mathrm{Na}$ figura 3, a seguir, são apresentados os versos do cordel contendo os principais resultados da avaliação do terceiro canteiro de obras estudado.

\section{CANTEIRO 3}

\author{
A obra dessas duas era \\ Modelo, de uma perfeita construção \\ Ficaram encantadas \\ E pensaram que só quem tem boa condição \\ Compra um apartamento \\ Nesta obra muito rica e de barão. \\ Era tudo em seus locais \\ Tubos de PVC juntos e guardados \\ Espaçados de acordo \\ Com a bitola como que fabricados \\ Ferramentas e uns tornos \\ Todos muito limpos e organizados. \\ Contaram as meninas que \\ Perto de dez essa obra ia tirar \\ Era uma nota boa \\ Que esta obra merecia ganhar \\ Tudo estava muito bom \\ E decidiram um verso assim criar:
}

\author{
Uma obra muito limpinha \\ Encontraram as engenheiras ao chegar \\ Deram uma espiadinha \\ Extintor bem na entrada a esperar \\ Os projetos na salinha \\ $\mathrm{O}$ engenheiro posto a analisar
}

\author{
Chegando na betoneira \\ Nenhuma porqueira pros peão tropeçar \\ Lá na mesa carpinteira \\ Uma boa gritaria deles a trabalhar \\ Alegria dos ferreiros \\ Ter mesa no canteiro pros ferros dobrar

$$
\begin{aligned}
& \text { Vital mesmo no canteiro } \\
& \text { Sobe e desce todo dia a trabalhar } \\
& \text { Pedreiro, aço, milheiro } \\
& \text { Pra alvenaria segura levantar } \\
& \text { Reboco com traço certo } \\
& \text { Parede encunhar para não fissurar }
\end{aligned}
$$

Figura 3 - Trecho do cordel do canteiro 3 avaliado.

Fonte: Autoria de discentes da disciplina de Tecnologia das Construções (2018)

O cordel confeccionado como resultado do planejamento de obras possui 48 estrofes, cada uma formada por seis versos, rimando sempre o segundo com o quarto, e o quarto com o sexto. A capa do cordel traz a imagem em foto reproduzindo uma imagem em xilogravura, técnica utilizada para elaboração da capa de um folheto em cordel, como mostra a Figura 4. E mostra também a representação gráfica utilizada para diferenciar atividades paralelas em redes de atividades em setas; a representação de uma rede em Rede Roy; uma das maneiras de como as atividades de uma rede Roy se interligam e a defasagem de uma atividade para outra, conteúdos abordados no corpo do cordel. 


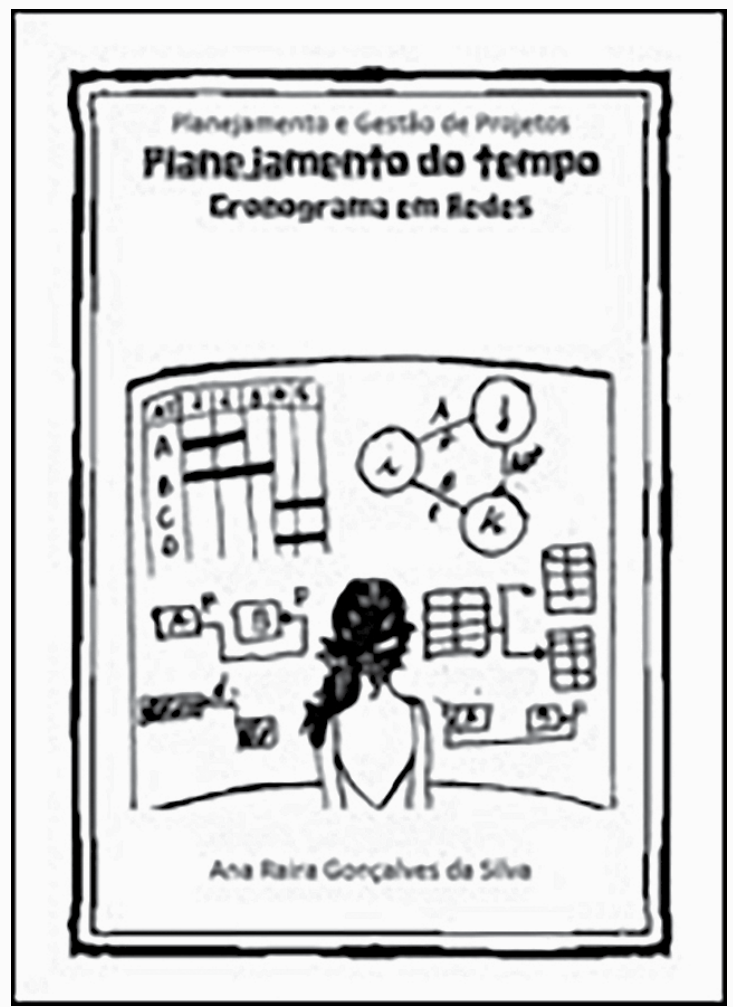


A página 1 e 2 do exemplar traz uma breve introdução sobre o assunto abordado e apresenta em seguida o tema proposto, como mostra a Figura 5. Com estas estrofes que caracterizam a introdução e a apresentação do tema, é desejável que o leitor compreenda que o tempo de duração de uma obra ou projeto constitui um dos elementos fundamentais do planejamento, e é feito a partir da duração de cada atividade, sendo necessário a elaboração de um cronograma que pode ser em redes ou em barras.

\author{
O tempo é tão precioso \\ Que é preciso planejar \\ E para que a sua obra \\ Não venha a fracassar \\ O planejamento do tempo \\ Neste cordel vamos estudar \\ Peço aqui muita atenção \\ Para tudo entender \\ Mas se alguma dúvida \\ Por ventura venha a ter \\ Mas se acanhe e pode sim \\ Voltar as folhas, ler e reler. \\ O tempo de duração \\ É assim determinado \\ Depende da atividade \\ E do serviço executado \\ Para cada um há de ter \\ Um prazo bem estimado. \\ O tempo total estimado \\ Da duração do projeto \\ Pode ser representado \\ Delineando seu trajeto \\ Seja tabular ou gráfica \\ Cronograma é o correto
}

\author{
Como no planajamento \\ Que deverá ser realizado \\ Para o controle do projeto \\ Também deve ser executado \\ Um cronograma em redes \\ Em obras é muito usado \\ O cronograma em Redes \\ Pode ser representado \\ Com atividades em seta \\ AES assim denominado \\ Ou atividades em nós \\ AEN assim chamado \\ Então para uma rede \\ De atividades em setas \\ Duas técnicas descritas \\ Conhecidas e corretas \\ Vou apresentar agora \\ De maneira curta e direta \\ Primeiro, a técnica PERT. \\ Não só de avaliação \\ Mas para o planejamento \\ Uma técnica de revisão \\ Dos programas executados \\ Sob nossa supervisão
}

Figura 5: Páginas 1 e 2 do cordel. Fonte: Discente da disciplina de Orçamento, Planejamento e Controle de Obras.

Os resultados demonstram como o uso da literatura de cordel possibilita a interdisciplinaridade, a exploração de temáticas de gestão e produção, a construção da linguagem de forma contextualizada, a democratização da escolha dos conteúdos, o estímulo à produção textual e o desenvolvimento da oralidade e das capacidades de expressão. (Nascimento, 2015). 


\subsection{PARÓDIA TECNOLÓGICA}

\section{A Figura 6 mostra a Paródia da música sobre Construções do Futuro produzida pelos discentes na disciplina de Gestão e Produção da construção.}

Maria me pediu pra fazer uma canção

Um resumo de um trabalho de gestão

O tema é "Habitação 10 anos no futuro"

Essa paródia vai ser um tiro no escuro. REFRÃO

Casas inteligentes, vamos ter com certeza

Integradas com a natureza

Casas pré-fabricadas: Construção modular

Geradores terão fonte solar

Evitar desperdício, aproveitando as sobras

Aumentar TI no canteiro de obras

Materiais multiuso, BIM em todo projeto

São as previsões de um futuro certo REFRÃO

Casas inteligentes, vamos ter com certeza

Integradas com a natureza

Casas pré-fabricadas: Construção modular

Geradores terão fonte solar

Agora eu quero fazer uma observação

Professora, por favor, seja mãe

Pegue leve nessa correção

Para isso precisamos que os construtores
Trabalhem juntos com pesquisadores, Com engenheiros, cientistas, vai dar tudo certo

Quase esqueço o camarada arquiteto REFRÃO

Casas inteligentes, vamos ter com certeza Integradas com a natureza

Casas pré-fabricadas: Construção modular Geradores terão fonte solar

Agora eu quero fazer outra observação

Professora, por favor, nos dê 10

Não nos faça cantar isso em vão

Evitar o desperdício, aproveitando as sobras

Aumentar TI no canteiro de obras

Materiais multiuso, BIM em todo projeto

São as previsões de um futuro certo REFRÃO

Casas inteligentes, vamos ter com certeza

Integradas com a natureza

Casas pré-fabricadas: Construção modular

Geradores terão fonte solar

Em toda construção: Gestão da produção

Figura 6: Paródia da música sobre Construções do Futuro.

Fonte: Autoria dos discentes da disciplina de Gestão e Produção da Construção (2020) 


\section{A Figura 7 mostra a Paródia da música sobre Gestão na Construção Civil produzida pelo discente na disciplina de Gestão e Produção da Construção.}

\section{GESTÃO NA CONSTRUÇÃO CIVIL}

Quando a bagunça aqui passou

E a estratégia não fez sentido

A notícia se espalhou

Fez da obra um castigo

Quando a exigência se apossou

Trazendo um canteiro arrumadinho

A organização ali brotou

Segue colaborando

Sem nem pensar para ajudar

A levantar e assim crescer

Custos acabados, tempos fechados

E eu levanto a mão pro alto e grito

Vem comigo quem é do bonde da gestão

Ooh ooh-ô-oh

Sou gestão, gestão tão tão

Ooh ooh-ô-oh

Ainda erguendo os meus prédios

Ajustes e serviços

Só assim não me perdi

Métodos enxutos

Nenhum desperdício

Pra ordenar quem não consegue reduzir

Do desempenho novo para avalia
Prazo pra falhas

Peças unidas sempre pra seguir

Se tentar nos para, não é bem assim

Teremos mais clientes do que antes

Do sul ao norte teve ajustes Músicas da alma pra grupo forte

Defeitos com a gente não pode

Minha comunicação é nosso som Criatividade e inovação são do bonde da gestão

Ooh ooh-ô-oh

Sou gestão, gestão tão tão

Ooh ooh-ô-oh

Sou gestão, gestão tão tão

Gestão-tão, gestão-tão

Gestão-tão, gestão-tão

Gestão-tão, gestão-tão

Gestão-tão

Engenheiro acredite

Não fique triste

Qualidade existe

Fortalece equipe

O som do repique

Peço que aplique

Figura 7: Paródia da música "Pesadão" sobre Gestão na Construção Civil.

Fonte: Autoria discente da disciplina de Gestão e Produção da Construção (2020) 
A Figura 8 mostra a Paródia da música sobre BIM (Buiding Information Modelling) produzida pelo discente na disciplina de Gestão e Produção da Construção.

\section{LET IT BIM}

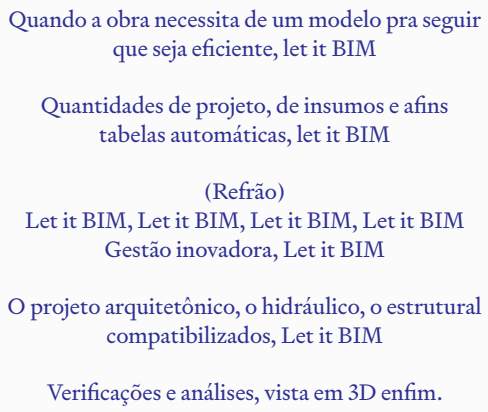

Modelo inteligente, Let it BIM

(Refrão)

Let it BIM, Let it BIM, Let it BIM, Let it BIM Gestão inovadora, Let it BIM

O futuro está chegando para a construção civil empresas e gestores, Let it BIM

Engenheiros e arquitetos inovando no Brasil fazendo diferença, Let it BIM

Figura 8: Paródia da música "Let it be" sobre Gestão na Construção Civil. Fonte: Autoria de discente da disciplina de Gestão e Produção da Construção (2020)

A poesia e as paródias apresentadas pelos discentes são apreciadas por outras turmas do curso de Engenharia Civil.

\subsection{POESIA SOBRE CONSTRUÇÃO ENXUTA}

Para escrever os versos sobre Construção enxuta o discente estudou e sintetizou o Webinar - Bate Papo Lean Construction: Desafios e Potenciais de Implantação, pelo canal da AVAL - ENGENHARIA. Apresentado por André Quinderé e pelo Professor Luiz Fernando M.Heineck. Estudou também as aulas disponibilizadas sobre Construção enxuta na dissertação de mestrado de Ana Paula Gessi Pacheco e Maria Duarte do Carmos Freitas - Aula 1.1 - Origem do Conceito Lean e Aula 1.2 - Introdução ao Conceito Lean.

A Figura 9 mostra a Poesia sobre Construção enxuta produzida pelo discente na disciplina de Gestão e Produção da construção. 


\section{FILOSOFANDO SOBRE CONSTRUÇÃO ENXUTA}

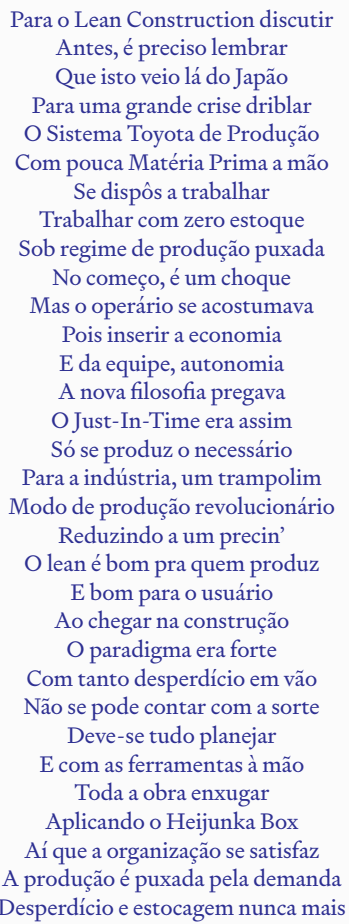

\author{
Não se produz mais só na voz \\ E a obra está sempre veloz \\ O primeiro que pede é o primeiro que se faz \\ Já o Andon é o sistema luminoso \\ Para parada ou problema informar \\ Por falta de material ou qualquer outra razão \\ A obra não pode parar \\ Reduzindo o tempo ocioso \\ O operário não fica na mão \\ E o cronograma vai se respeitar \\ Mas não bastam as ferramentas \\ Para a filosofia enxuta seguir \\ Para sair do desperdício e das obras lentas \\ Tem que se constantemente nutrir \\ A participação de todo operário \\ E juntos, num esforço diário \\ Um melhor processo construir \\ Esta filosofia tem pilares \\ São os seus norteadores \\ Produzir sempre de forma eficiente \\ Traz do mercado e suas dores \\ Independência e novos ares \\ Agradando aos clientes pela perfeição dos seus lares \\ Não é só produzir mais com menos \\ Ou alcançar o fluxo contínuo \\ Na construção enxuta que vemos \\ Pela qualidade que aferimos \\ Todos podem dormir plenos \\ Pois edificação bem feita e sem sobra \\ Do peão ao mestre de obra \\ Às boas práticas, sorrimos
}

Figura 9: Poesia - Filosofando sobre Construção enxuta - sobre Gestão na Construção Civil. Fonte: Autoria de discente da disciplina de Gestão e Produção da Construção (2020).

\section{CONSIDERAÇÕES FINAIS}

Como observador da atividade artística realizada pelos discentes, o docente concorda com Steiner quando afirma que esse tipo de prática proporciona sentido para compreender também com o intelecto e de permear também como o senso de dever aquilo que o indivíduo aprendeu a ver na arte como o belo e o humano puramente livre.

As produções técnicas e artísticas dos estudantes da disciplina de Tecnologia das Construções; Orçamento Planejamento e Controle de obras e de Gestão da Produção na Construção do curso de Engenharia Civil da UFERSA mostra que a sensibilidade pode ser ativada. 


\section{REFERÊNCIAS}

BACHEGA, César Augusto. Pedagogia Waldorf, um olhar diferente à educação. An. Sciencult, v.1, n.1, Paranaíba, 2009. P. 360-369.

BRESSIANI, L. A utilização da andragogia em cursos de capacitação na construção civil. 2016.

COELHO, M. J. Princípios da andragogia como ferramenta para a criação de um ambiente transformador nas organizações 2016.

LANZ, Rudolf. A pedagogia Waldorf: caminho para um ensino mais humano. 6. ed. São Paulo: Antroposófica, 1998.

LIMMER, Varl V. Planejamento, orçamento e controle projetos e obras. Rio de Janeiro: LTC, 2012.

NASCIMENTO, C. R. S. D. A produção de poesia popular como prática pedagógica inovadora: um estudo de caso. 2015.
ROMANELLI, Rosely Aparecida. A arte e o desenvolvimento cognitivo Um estudo sobre os procedimentos artísticos aplicados ao ensino em uma escola Wladorf. Tese de Doutorado. Faculdade de Educação (FE) da Universidade de São Paulo.274p. 2008.

SANTOS, W. S. Andragogia e a educação de idosos, jovens e adultos. Alumni-Revista Discente da UNIABEU-ISSN 2318-3985, v. 4, n. 7, p. 38-47, 2016. ISSN 2318-3985.

SOUTO, P. C.; SOUSA, A. A. D.; SOUTO, J. S. Academic knowledge versus popular knowledge: cordel literature in the teaching of agricultural practices. Revista Brasileira de Estudos Pedagógicos, v. 97, n. 245, p. 195-212, 2016. ISSN 2176-6681. 


\section{Maria Kellynia Farias Alves}

\section{PRETAGOGIA: TRILHAS NA \\ PESQUISA E NA FORMAÇÃO AFRORREFERENCIADA}

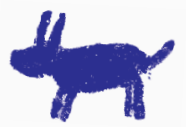

Nea onnim no sua a, obu'

\section{PARA COMEÇO DE CONVERSA...}

O símbolo adinkra, tradição oral do Povo Akan, que abre este texto representa a busca por conhecimento e em uma perspectiva inclusiva, pois, "Aquele que não sabe pode saber por meio do aprendizado" (adágio ganense) representando os caminhos em busca do conhecimento. Esta reflexão inspirou este trabalho que objetiva refletir sobre as contribuições da Pretagogia para educação por meio das pesquisas e práticas de formação docente, conhecimento como partilha, movimento afro-ancestral.

\section{PRETAGOGIA: CAMINHOS E PRINCÍPIOS AFRORREFERENCIADOS}

Uma sexta-feira de novembro, o sol se punba pintando o céu de laranja-avermelhado e nuances de dourado, a luz que atravessava entre árvores as emoldurava, encantando osparticipantes do 'Memórias de baobá', na Praça dos Mártires, em Fortaleza. Naquele ano o 'Memórias de Baobá, o evento-formaçấo promovido pelo Núcleo das Africanidades Cearenses, chegava à sua sétima ediçấo. O chẫo redondo 'Patrimônio Religioso de Matriz Africana' com Wanderson Flor do Nascmento, Bábara Peres, Kiusam de Oliveira e mediadospor Kelma Matos já se iniciava, todos/as sentavam-se ao redor do baobá centenário para partilhar os saberes afro-ancestrais. Eram sete ediçôes, maioridade nas religióes africanas e naquela sexta, recebemos um presente: sem que soubéssemos, Mãe Beata de Iemanjá1 visitou o Baobá e os dois

${ }^{1}$ Beatriz Moreira Costa, Mãe Beata de Iemanjá faleceu meses depois do evento, no dia 27/05/2017. 
mais velhos ali se encontravam: o baobá e a ialorixá. A emoção tomou conta de cada pessoa presente e, em contato com o chão, pelo encantamento epela ancestralidade africana, animadospela força vital, aprendemos na diáspora e suas interlocuçôes com a educação.

O conto-memória apresentou o território epistemológico no qual esta conversa transcorre: os saberes da ancestralidade, da resistência e do encantamento nas cosmopercepções africanas (OYĚWÙMÍ, 2002). Corpos-territórios que a colonialidade e o racismo vem tentando negar/subalternizar, mas que se mantiveram em movimento como forma de resistir, como na ginga de uma roda de capoeira, na sabedoria das folhas sagradas, nas estéticas, nas organizações negras, rememorando na circularidade ancestral, na africanidade, esse rosto comum africano (MUNANGA,2020) e presente nas africanidades brasileiras (SILVA, 2003) promovendo sentidos outros na formação docente.

O exercício desde a perspectiva aforreferenciada implica pensar com o corpo todo, sem privilegiar apenas uma dimensão do processo. Corpo-memória, pelo pertencimento e história sendo marcado pela boniteza do diverso em seus movimentos quebrados, lentos e ou intensos, ginga ao filosofar, gira ao problematizar, pisa no chão e consolida conceitos afro-diaspóricos e pelos encantados nas indigineidades. Numa perspectiva de um "pensamento pluriversal" (RAMOSE, 2011) a epistemologia não tem um senhor apesar do que se tem construído na formação acadêmica e legitimada nos espaços de poder.

Este corpo afroancestral busca a trilha que se encontra com a "descolonização epistemológica" (QUIJANO, 1992). Este movimento dialoga com a defesa de ruptura com o racismo epistemológico que tem legitimado as expressões de negação e subalternidade por meio de uma modernidade eurocêntrica, rompendo com o "ego científico" que levou a crer que somente sob as epistemologias e metodologias ocidentais seria possível conhecer a realidade (ROBLES, 2013). Frantz Fanon através de uma elaboração precisa sobre os mecanismos que produzem o corpo "colonizado", alertando sobre essa relação que passa pelos processos formativos e anuncia a necessidade de descolonização que geraria novas formas de ser/estar, sociabilidades, reinvenção de sujeitos em sua "verdadeira humanidade", na perspectiva de movimento/luta/formação pois "na verdade, criação de homens novos. Mas esta criação não recebe sua legitimidade de nenhum poder sobrenatural; a 'coisa' colonizada se faz no processo mesmo pelo qual se liberta” (FANON 1979, p.27). Este movimento vem romper com a "ferida colonial" (FANON, 1968) que engendram a naturalização dos processos de violência, subordinação e desumanização e assim produzem a exclusão ou inclusão subalternizada.

As escolhas que promovem essas rupturas conduzem às bacias epistêmicas afrorreferenciadas, implicando relações outras com a ideia de rigor (FREIRE,1986), de metodologias e epistemologia, bem como nossa relação com o mundo. Por isso a insistência na ideia de movimento, tomado aqui na perspectiva banta de força vital, pois todos os seres são energia, força e "não uma entidade estática, e por isso a pessoa humana tem caráter dinâmico" (DAIBERT, 2015, p. 14). 
É a ancestralidade, como teia de ananse que une estas críticas-reflexões e referências. Esta perspectiva intenta que sejam construídos, alimentados, semeados paradigmas outros que se amparem na complexidade das cosmovisões ou cosmo-sensações ancestrais que dialogam com o encantamento, com a ancestralidade, como forma de ser-estar-sentir no mundo, pois:

Compreendemos que sem a ancestralidade ficamos perdidos no tempo e no espaço. Pois, é ela que potencializa o presente delineado pelo passado, posto que viver o presente é valorizar cada momento e reconhecer as experiências do passado atualizando-as. A ancestralidade pressupõe que estejamos inteiras/os em nossas ações, assim o encantamento nasce, age... $O$ viver perpassado pela ancestralidade é a potencialização do presente e da comunidade, do bem-viver coletivo. Encantamento é esse comprometimento diário, ação, é o visível do invisível (ancestralidade). (ALVES, MACHADO, SANTOS, 2017, p.4 )

Nestes movimentos de re-existência, os povos africanos na diáspora elaboram novas formas de manter seus valores civilizatórios, de acessar a ancestralidade e organizar resistências, dentre elas, os quilombos, como estratégia de enfrentamento à força colonial escravista. E como explica a pesquisadora "atlântica", Beatriz Nascimento (1985), se constituiu como alternativa, como sinônimo de povo negro, de "esperança para uma melhor sociedade".

Como aquilombamento, a Pretagogia, esse referencial teórico-metodológico que tem nos valores e saberes afrorreferenciados elementos aglutinadores/condutores nas experiências de ensino-aprendizagem, vem sendo gestado pelas acadêmicas: Sandra Petit, Geranildes Costa e Silva e Rebeca Alcântara e Meijer que entenderam que há especificidades e diversidade das expressões da identidade e sociabilidade afrobrasileira que demandam referenciais que se fundam em valores de matriz africana que abrangem desde a tradição oral, corpos como produtores de saberes e o reconhecimento do lugar social atribuído a negros e a negras como fundamentos (ALVES, 2015).

Nesta seara, elabora seus princípios no corpo afroancestral como produtor de conhecimentos, na ancestralidade e cosmopercepção africanas, valores/princípios herdados da 'Mãe Àfrica' e assim, provocando uma inversão epistemológica dos processos de negação e silenciamento, buscando revelar o pertencimento como um de seus princípios:

Daí não haver dúvida de que a teorização que a Pretagogia sugere exige um mergulho dentro de si, para falar na primeira pessoa, de seu lugar, não somente numa linhagem biológica que envolve a imensa maioria das famílias brasileiras, componentes próximos ou distantes afrodescendentes, mas, 
sobretudo, marcadores culturais africanos e afrodiaspóricos, esses últimos coletivos e absolutamente inegáveis.(PETIT, 2015, p. 169)

Este referencial tem instigado a reflexão sobre outros paradigmas a partir das intervenções e pesquisas. Os espaços formativos transitam entre a educação formal, seus níveis e modalidades como Educação de Jovens e Adultos e na Educação Infantil, na formação docente, na universidade, na dança, nas expressões da cultura afropopular, dentre outros espaços-tempos educativos. O pertencimento, ancestralidade e tradição oral africana se expressam nos marcadores e nos princípios das africanidades. Na perspectiva das construções de paradigmas afro-brasileiros na formação de professores/as, traduz o espírito comunitário tanto como inspiração filosófica quanto na construção das metodologias, entendendo a construção coletiva como potência que se enriquece na heterogeneidade dos grupos com explica Petit:

A Pretagogia valoriza por demais a construção coletiva do conhecimento, inclusive pela nossa relação com a educação popular, na qual nós fundadoras temos inserção. Em subgrupos e em coletivos maiores é que se atinge de modo geral maior heterogeneidade e riqueza de ideias, noções e conceitos, permitindo assim problematização e, sobretudo, a construção de relações comunitárias, algo muito valioso na cosmovisão africana, uma vez que eu só existo por meio dos outros, ou seja alimento-me do convívio e da troca. A educação precisa dessa dimensão espiritual para gerar afetos transformadores. (PETIT, 2015, p 173.)

A Pretagogia é atravessada pela dimensão estética que abrange os aspectos transcendentais (espiritual/imaterial), éticos e materiais, reelaborando a leitura do que é belo. Estética esta fundada na diáspora e suas expressões nos espaços cearenses, tanto a pesquisa quanto experiência de formação de professores.

\section{PESQUISAS-PRÁTICAS PRETAGÓGICAS: CORPOS AFROANCESTRAL EPISTEMOLÓGICO}

Problematizar os caminhos epistemológicos e metodológicos mais que exercitar a coerência e unidade ao trabalho gera discussão sobre concepções, cosmovisões sobre conhecer/pesquisar/aprender. Neste papel de inspiração, os saberes da tradição oral mantêm a comunicação entre corpos/mentes/territórios e epistemologias. Assim, esta comunicação é presente na vida cotidiana, traduzindo a cultura como forma de perceber e intervir no mundo, uma expressão de leitura de si, de seus ancestrais e da realidade. 
A tradição oral como forma de leitura de mundo, é saber sendo transmitido por meio da oralidade, envolvendo os brincantes nos tecidos da vida, dos registros de resistência por meio do seu cotidiano. Petit explicita a relevância do diálogo com as tradições orais, colher os saberes e valores, a fim de elaborar conexões entre valores e práticas corporais envolvidas que assim se estabelecem como:

as práticas corporais envolvidas, inspirações concretas para a didática em sala de aula, como por exemplo, o uso dos cinco sentidos, a diversidade de linguagens artísticas, a transdisciplinaridade, abolição da própria ideiade disciplina, a partir de um trabalho baseado em temas geradores,onde diversas dimensões do conhecimento se façam presentesconcomitantemente, sem a excessiva fragmentação que nós vemoshoje nos currículos escolares e universitários. É também a oportunidadede chamar mestras e mestres da cultura para dentro daescola, para nos repassarem seus ensinamentos, e para, também,realizarmos aulas de campo fora da escola, para vivenciarmos as tradições no seu ambiente natural de produção e de criação.(PETIT, 2015, p. 170

As expressões da tradição oral têm sido presentes nas pesquisas e práticas pretagógicas e naquelas em diálogo com a pretagogia tais como a Sociopoética (ADAD,PETIT, GUATHIER), a Filosofia da Ancestralidade e do Encantamento (OLIVEIRA 2005, MACHADO, 2019), constituindo um complexo movimento de comunicação entre princípios e práticas.

Apresento algumas das pesquisas produzidas no NACE, que orientadas pela professora Sandra Petit que articulam os princípios afrorrefeenciados, tendo como referenciais a Pretagogia, a ancestralidade, o encantamento, a cosmovisão africana e as expressões culturais nesta matriz. A pesquisadora e coquista Alessandra Sávia da Costa Masullo(2015) pesquisou os significados da brincadeira do Coco para as mulheres do Coco da Batateira, no Crato - CE. A pesquisa apresentou a relação com as africanidades, a "importância do Coco como eixo de formação e estruturação da vida" dessas mulheres. Festa, trabalho, alegria no 'cunvidado', forma tradicional de mutirão no Pará ao som/espiritualidade presente no samba de cacete, compõem o trabalho de Carmem Lúcia Barbosa- Calú,(2015).Nos mutirões a solidariedade e comunitarismo dialogam perfeitamente com as ancestralidades, sendo a dança memória e identidade que articulam os sujeitos.

Claudia Oliveira da Silva (2015), sobre o pertencimento afroquilombola nas comunidades quilombolas Serra do Juá em Caucaia e Boqueirãozinho. A releitura do Pano de Pente guineense registrou o re-encanto com a ancestralidade afroquilombola. A pesquisa de Rafael Ferreira da Silva (2015) tratou do ritual das ladainhas de capoeira angola, as contribuições da capoeira e da Pretagogia para a produção didática no mesmo quilombo do Juá, por meio do 'livro de ladainhas' produzido 
pelos quilombolas valorizou-se memórias, costumes e pertencimento. O ofício das rezadeira quilombolas foi investigado por Maria Eliene Magalhães da Silva (2015) onde as capulanas africanas revisitadas registraram a relação entre a reza e suas vidas em comunidade.

O trabalho de Samuel Morais (2018) Silva tratou dos caminhos da pesquisa-formação fundamentada na Pretagogia em uma escola do Crato-Ce, apresentou a relação entre a cosmovisão africana, e cultura afro-cratense e a importância dessa abordagem na escola. Carlos Gerson Carlos Matias de Sousa (2018) ao investigar outra dimensão pretagógica: a ênfase o corpo-dança afroancestral, compartilhou "as proposições pedagógicas de ensino-aprendizagem-criação em danças afroancestrais", sendo o corpo o produto didático, texto-narrativa-dança propiciou o "ser comunidade" em reconexão afro-ancestral por meio da dança.

No âmbito das práticas, a fim de ilustração-reflexiva, retorno ao 'Memórias de Baobá', ponto de inicio e de chegada desta conversa. O 'Memórias' é um evento-formação realizada pelo NACE desde 2010, nascido da sensibilidade atenta da professora Sandra Petit que em diálogo na Pós-graduação que soube por Joelma Gentil, pesquisadora e militante do movimento negro, da existência do Baobá centenário. Ali nascia uma experiência de rupturas e retomadas na ancestralidade africana no Ceará, que teve seu nome inspirado no livro "A semente que veio da África" de Heloísa Pires Lima (2005).

As práticas-diálogo se entrançam nas pesquisas e na cultura afropopular. Vivências-debate sobre o coco, o reizado, a filosofia africana, os quilombos, espiritualidades-epistemologias indígenas, os afoxés, maracatus, a etnomatemática, a contação de afro-histórias, possibilidades múltiplas onde pensadores da cultura e da universidades produzem encontros epistemológicos atravessados pela ancestralidade e pelo encantamento que como explica Machado: "modo de ser e estar mundo, pois é ética do bem-viver, tem a(s) cultura(s) que tem as experiências / vivências como aquela que dá sentido à vida.(MACHADO, 2019, p. 26)

Os princípios presentes no 'Memórias' abarcam desde a tradição oral africana, a ancestralidade, o corpo-dança afroancestral, a Pretagogia, o quilombo, a intergeracionalidade e reflexão-prática. Como espaço-tempo-formação, pesquisadores/a, professores universitários e da educação básica, estudantes da educação básica e universidade, movimentos sociais e brincantes são convidados assentar-se junto ao baobá centenário e ocupar a praça. Durante o evento-formação, a circularidade, o contato com o chão, as reflexões-ações sobre a epistemologias africanas e afro-brasileiras potencializam as proposições teórico-práticas sobre a educação das relações étnico-raciais, bem como a extensão destes pressupostos para a escola, à comunidade, à vida alargando os paradigmas de escola-formação que desejamos. 


\section{CONSIDERAÇÕES: A CONVERSA PRECISA CONTINUAR}

As pesquisa e a formação de professores na perspectiva afrrorefereniada, onde não há dissociabilidade entre o sensível, o prático, o aprender-ensinar atravessados pela ancestralidade, pela comunidade, pela alacridade formam o esteio para reflexões decoloniais ou contra-colonais na perspectiva de sulear o caminho a partir da África e da diáspora. A formação docente na perspectiva pretagógica é território fértil capaz de reelaborar saberes e práticas, propiciando a reinvenção da práxis docente para efetivação de uma didática antirracista.

\section{REFERENNCIAS}

ALVES, M.K.F. Resistência Negra no Circulo de Cultura Sociopoético: Pretagogia e Produção Didática para a Implementação da Lei ' $0.639 / 03$ no Projovem Urbano. Dissertação (mestrado) -Faculdade de Educação, Programa de Pós-Graduação em Educação. Universidade Federal do Ceará, Fortaleza, 2015.

DAIBERT, Robert. A religião dos bantos: novas leituras sobre o calundu no Brasil colonial. Estudos Históricos Rio de Janeiro, vol. 28, no 10 55, p. 7-25, janeiro-junho 2015

FANON, Franz. Os condenados da terra. 2ed. Trad. J. L. de Melo. Rio de Janeiro: Civilização brasileira, 1979.

FREIRE, Paulo, SHOR, Ira. Medo e Ousadia - O Cotidiano do Professor. Rio de Janeiro: Paz e Terra, 1986.

MACHADO, Adilbênia Freire.SABERES Ancestrais Femininos Na Filosofia Africana: Poéticas De Encantamento Para Metodologias E CURRÍCULOS AFRORREFERENCIADOS. Tese (doutorado) - Universidade Federal do Ceará, Faculdade de Educação, Programa de Pós-Graduação em Educação, Fortaleza, 2019.

NASCIMENTO, Beatriz. O conceito de quilombo e a resistência cultural negra. In: RATTS, Alecsandro (Alex) J. P. Eu sou atlântica: sobre a trajetória de vida de Beatriz Nascimento. São Paulo: Instituto Kuanza; Imprensa Oficial do Estado de São Paulo, 2006.

OYĚWÜMÍ, Oyèrónké. Conceituando o gênero: os fundamentos eurocêntricos dos conceitos feministas e o desafio das epistemologias africanas. Tradução para uso didático de: OYĚWÙMÍ,Oyèrónké. Conceptualizing Gender: The Eurocentric Foundations of Feminist Concepts and the challenge of African Epistemologies. African Gender Scholarship: Concepts, Methodologies and Paradigms. CODESRIA Gender Series. Volume 1, Dakar, CODESRIA, 2004, p. 1-8 por Juliana Araújo Lopes.
PETIT, Sandra. Pretagogia: Pertencimento, Corpo-Dança Afroancestral e Tradição Oral Africana na Formação de Professoras e Professores. Contribuições do Legado Africano para a Implementação da Lei 10.639/03. Fortaleza: EdUECE, 2015.

QUIJANO, A. Colonialidade do poder, Eurocentrismo e América Latina. In: LANDER,E(Org.). A colonialidade do Saber: eurocentrismo e Ciências Sociais.Trad.Júlio Cesar Casarin Barroso Silva.3 ed., Buenos Aires, 2005.

RAMOSE, M. B. Sobre a Legitimidade e o Estudo da Filosofia Africana. Tradução: Dirce Eleonora Nigro Solis, Rafael Medina Lopes, Roberta Ribeiro Cassiano. Ensaios Filosóficos, Volume IV - outubro/2011. P.6-24.

ROBLES, G.A.A. Reportando Desde un Frente Decolonial: La Emergencia del Paradigma Indígena de Investigacion. En: Experiencias, luchas y resistencias en la diversidad y la multiplicidad. Bogotá: Asociación Intercultural Mundu Berriak. 2013. 


\section{Núbia Agustinha Carvalho Santos}

\section{OUTRIDADE: O CORPO COMO POTÊNCIA DE ESCRITURA NA PERFORMANCE}

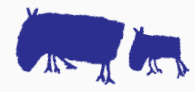

A performance no campo das Artes Visuais tem se mostrado um campo fértil de produção artística contemporânea. Artistas como Priscila Rezende, Elton Panamby, Jota Mombaça, Regina Galindo, dentre outros, pensam o corpo como esse lugar de escritura, político, no qual se discute gênero, questões etnorraciais, contrapondo-se a estética hegemônica. A linguagem da performance no espaço urbano ou nas instituições museológicas tem uma trajetória consagrada, mas ela pode vir a ser uma opulenta experiência de produção artística, também em espaços escolares. Alguns autores debatem o assunto, entre eles destaco Marina Machado (2010), que pensa a criança como performer. O corpo carrega imagens, palavras, comunica, cria laços, captura olhares. No corpo habitam discursos, embora muitas vezes inaudíveis, invisíveis. A História da Arte se faz, desfaz, se refaz muitas vezes a contrapelo. Ausências, presenças que se inscrevem na história. Vidas presentes nos textos, imagens e roupas convidam a "Outridade" a tocá-las. Fazer existir, resistir de outro modo, noutro espaço, tempo, corpo ambulante, comunicante. A corporeidade é escrita e vivida com outros corpos. Escrever para existir, suplantar a morte no escrito. Ler o corpo, escrever o corpo, se dizer no corpo vestido ou nu. Diferentes vozes, podem habitar a corporeidade: sufocantes, nebulosas, delicadas, caladas, violentas, branca, preta, ameríndia, alegres, tristíssimas. Espinosa indagava: "O que pode o corpo?..." Nesse sentido, penso a potência do corpo como lugar de expressão, de escrita, tenho o intuito de apresentar três performances de minha autoria, em que a presença do Outro é parte constitutiva da obra. A primeira, "Trouxa de Afetos ou histórias cartografadas", mostra a potência do Outro na produção da obra. Esta poética foi realizada com doações de roupas e sínteses de memórias e histórias pujantes vividas pelos doadores, com essas indumentárias. A segunda performance intitulada, "Retalhistas: eu e os Outros", foi concretizada com a participação de estudantes do 9ํA을 do Ensino Fundamental, de uma escola pública de Fortaleza/ $\mathrm{CE}$, em que confeccionamos uma indumentária, inspirada na Série Relevos Brancos 
da artista cearense Heloísa Juaçaba (1922-2013); a terceira, "Narrativas poéticas de pesquisas", a exemplo das demais, o Outro é parte importante na construção da obra. Nesta foram doados imagens e fragmentos de textos de pesquisas por estudantes/pesquisadores da graduação e pós- graduação, integrantes do Grupo de Pesquisa LUDICE (Ludicidade, Discurso e Identidades na Práticas Educativas), da Universidade Federal do Ceará/UFC. As três experiências performativas apresentam o corpo como um lugar de conhecimento artístico, sensível e vivido, em diferentes contextos sociais e culturais. A co-criação é um elemento presente no processo da performance. Sem o Outro, não há obra. A roupa como uma segunda pele em que escritos e imagens produzidas pelos Outros são transformadas em linguagem poética. A produção performática que venho realizando nos últimos seis anos se fundamenta na Estética Relacional de Nicolas Bourriaud (2009), na qual o autor tece considerações sobre o caráter das sociabilidades na arte, a potência da imagem em religar as relações com os outros. As performances supracitadas encontram na Cartografia de Deleuze e Guattari (2011; 2012), embasamento teórico-metodológico para pensar os processos de criação, de forma rizomática. Vida e Arte como devires.

O termo performance, para Regina Melim, tem um caráter genérico, mas no campo da Artes Visuais, performance trata-se de uma "[... ] categoria sempre aberta e sem limites". Tal, reconhecimento se dar nas décadas de 1960 e 1970. É importante lembrar que, antes já existia performance, só que ainda não era considerada uma categoria, e também tinha outras denominações. Melim (2008, p.22) cita diversos exemplos, dentre eles, destaco o do brasileiro Flávio de Carvalho, cujas práticas interdisciplinares são vividas nas suas ações performativas. $\mathrm{O}$ artista nomeava de experiências. A primeira delas data de 1931, Procissão do Corpus Christi. Carvalho com um boné na cabeça, gesto considerado agressivo e desrespeitoso pelos fiéis. Na experiência n. 3, realizada em 1956, o artista propôs um traje Nem Look para o homem tropical brasileiro. Conforme Melim trata-se de uma "saia, blusa de mangas fofas, chapéu de organdi com largas abas e meias arrastão (MELIM, 2008, p.22). A autora apoiada nas idéias de Stiles vai dizer ainda que, "Performances podem ocorrer sem audiência e sem documentação alguma, ou podem ser registradas através de fotografias, vídeos e filmes, entre outros. E esses meios acrescentados às ações se tornam a base de uma forma híbrida de performance (MELIM, 2008, p.38)

A ideia da Performance "Trouxa de Afetos ou História Cartografadas", nasceu no primeiro semestre de 2016, no curso de Licenciatura de Artes Visuais do Instituto Federal de Educação Ciência e Tecnologia do Ceará, (IFCE), na Disciplina de Ateliê de Poéticas Visuais Contemporânea, ministrada pelo artista/ professor/pesquisador Herbert Rolim. Eu já vinha me interessando por ações performáticas, participar dos ateliês de performances, bem como do Grupo Meio Fio de Pesquisa e Ação, do IFCE, possibilitou descobri-me como artista performer. A coleta de roupas começou com uma proposição para a disciplina e teve outros 
desdobramentos, mesmo com o fim da disciplina, continuei recebendo doações de indumentárias e histórias vividas com elas. Ao mesmo tempo, em que leituras me alimentavam na construção de um pensamento em arte, destaco aqui o livro "O Casaco de Marx: roupas, memória, dor, de Peter Stalybrass que discute entre outras coisas, a dimensão afetiva nas roupas. Com esta performance, participei do Encontro Guattari-Cariri organizado pelas professoras Ada Kroef e Gisele Gallicchio, em 2016, pelo Instituto de Cultura e Arte ICA da Universidade Federal do Ceará. A performance aconteceu no Geopark, no Cariri, região Sul do Ceará. Meus trabalhos performáticos são atravessados pelas ideias rizomáticas, cartográficas de Deleuze e Guattari $(2011 ; 2012)$.

Outro teórico que fundamenta minha poética é Nicolas Bourriaud. Ele diz que: "[...] o artista habita as circunstâncias dadas pelo presente para transformar o contexto de sua vida (sua relação com o mundo sensível ou conceitual) num universo duradouro. Ele toma o mundo em andamento [...]" (BOURRIAUD, 2009, p.19). É nesta perspectiva da Estética Relacional do autor, que minhas performances vêm sendo pensadas e realizadas.

Apresentei também "Trouxa de Afetos" no "XI Encontro Regional Nordeste de História Oral" da UFC, onde recebi mais algumas doações de roupas e de histórias para minhas ações performáticas. Destaco aqui, um depoimento de uma doadora:

Regata preta, indicada para corrida, tecido projetado para manter a ventilação e afastar o suor da pele'. De mãos, olhares e sorrisos consubstanciados por laços consanguíneos Regata chega como presente. Presente que, sabe-se não é novo, mas é presente de irmã mais velha para irmã mais nova. Um dia a irmã mais velha parte. Não há tempo de dizer adeus à irmã mais nova. A viagem é longa e a vida, com todos os seus enigmas, as separa. Contudo, há um alento: a Regata é traída pela qualidade do tecido, o vento bate teimosamente e o suor não se esvai; a água, mesmo em infinitas lavagens, não dissolve as gotas de suor que agora se fundem em vivências, em memórias, em afetos, em saudade... ${ }^{1}$

Memórias poéticas carregadas de saudade e dor. Afetos transformados em poesia visual. A potência das palavras, das memórias e das histórias narradas nas tag das indumentárias nos tocam, nos afetam. A OUTRIDADE é parte essencial da obra. Esses objetos afetivos doados são transformados em obra de arte abrindo outras possibilidades de leituras e nos fazendo escavar outras camadas de sentidos.

${ }^{1}$ Sheila Medeiros (professora/pesquisadora. Texto da doado no "Encontro de História Oral", 04,05.2017. 


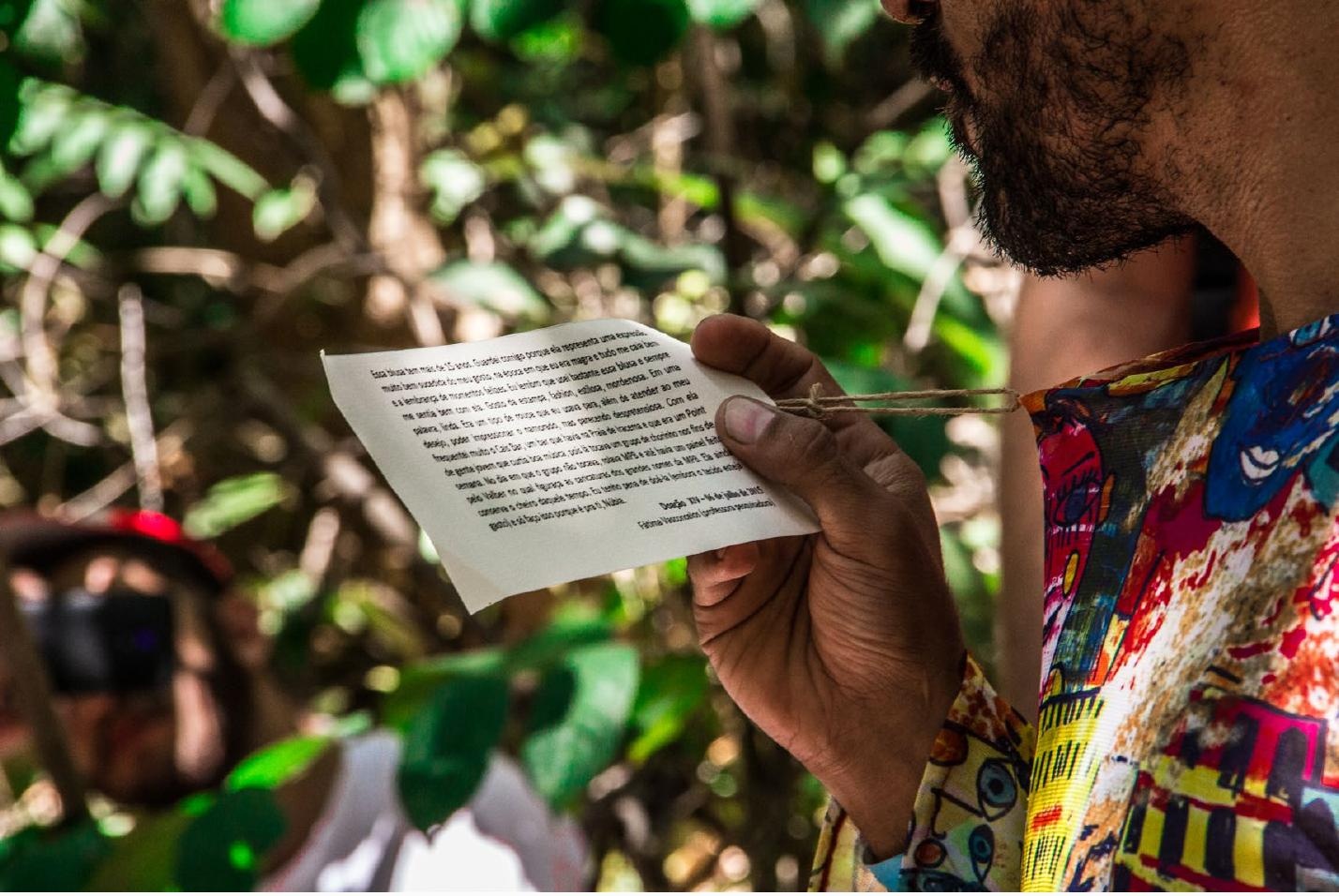

Figura 4 - Trouxa de Afetos ou Histórias Cartografadas, 2017. Foto: Paloma Pajarito.
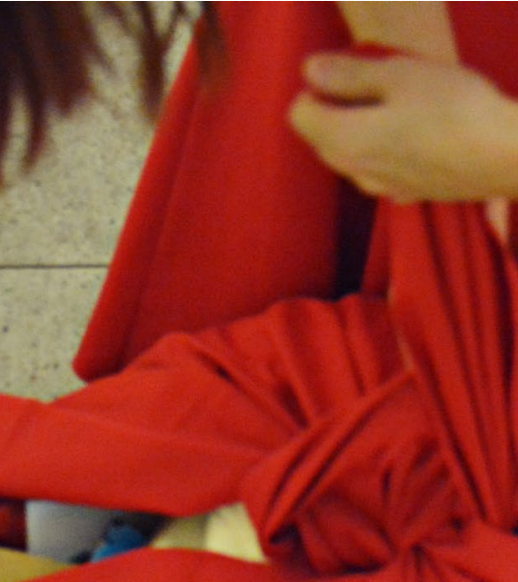
O contexto em que foi realizado a próxima performance foi durante a Regência do Estágio Supervisionado II, do IFCE, em que apresentei obras da artista Heloysa Juaçaba (1922- (2013). Vistamos o Museu de Arte da UFC - (MAUC), instituição em que Juaçaba colaborou ativamente na criação, além de ressaltar o atuante papel dela, como gestora cultural em Fortaleza.

Eu e os estudantes do 9ํAo da Escola Municipal Centro dos Retalhistas, realizamos durante quase três meses nas aulas de Artes, ministrada uma vez por semana, uma indumentária com cordões vermelhos de rede de dormir e pequenas placas de Eucatex ${ }^{2}$ perfurados. Esta roupa para a performance teve como referência visual a Série Relevos Brancos de Heloysa Juaçaba. Os trabalhos desta artista cearense são marcados por várias correntes artísticas, mas é com a arte construtiva, a série dos relevos brancos, pensada matematicamente as formas desenhadas com cordões, que Juaçaba alcança na Crítica de Arte seu maior reconhecimento plástico. A artista com seu olhar atento para a cidade encontra nos punhos de redes o material para a sua criação. ${ }^{3}$

Durante o estágio tematizei sobre arte urbana, sobre a visualidade, todo esse colorido dos artefatos vendidos nas feiras, modo de vestir, de viver, habitar das pessoas, enfim as "artes de fazer", como nos faz pensar Michel de Certeau (2009). Foi nesse caminhar pelas ruas que Juaçaba foi instigada a criar com os cordões de redes vendidos nas feiras do Mercado São Sebastião. Assim, ela inicia o processo artístico dos Relevos Brancos, na década de 1980.

Importa dizer aqui, o processo da performance "Retalhistas: eu e os Outros" foi intenso. Os estudantes pintaram as plaquinhas de "madeira" desenharam de formas livre com cordões. Relataram-me em depoimentos que era a primeira vez que estudavam sobre Performance e construíam um objeto para uma ação performativa. Quando disse que usaria a roupa numa performance na rua, perguntaram se poderiam ir comigo. Falei que se a escola autorizasse seria uma experiência gratificante estar com eles na realização da ação.

Depois de performar na rua, visitamos o MAUC para que os alunos conhecessem uma das obras da série Relevo Branco, série estudada em sala de aula por meio de slides. A obra não estava na exposição, porém a reserva técnica foi aberta generosamente pela museóloga Graciele Siqueira. Em pequenos grupos nos organizamos para o encontro com a obra que foi inspiradora para a performance "Retalhistas: Eu e os Outros", construídas coletivamente com os estudantes.

${ }^{2}$ Placa de aglomerado de eucalipto para moveis.

${ }^{3}$ Disponível em: https://nubiagustinha.wordpress.com/publicacoes/ Acessado em 25.10.2020. 


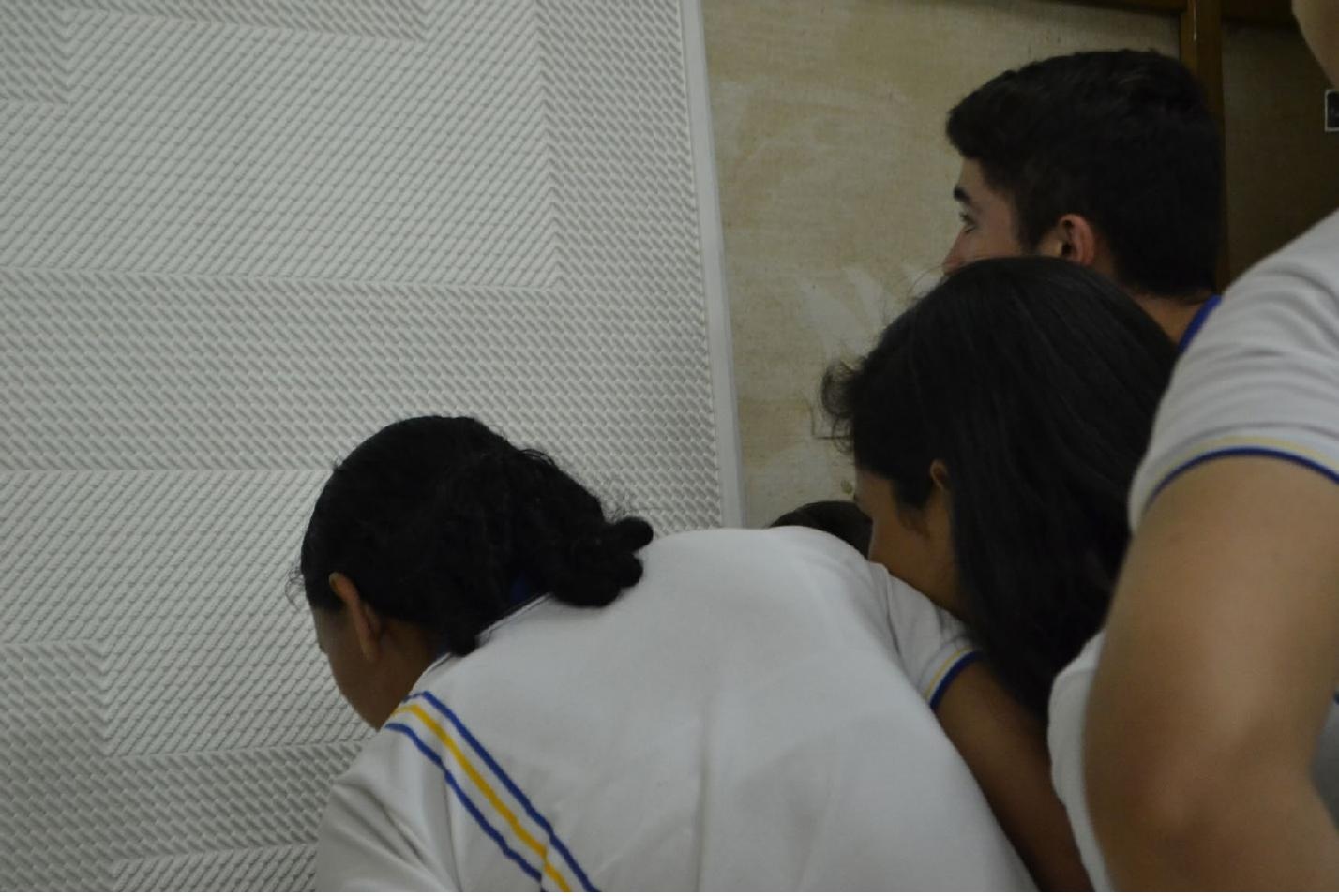

Figura 5 - Estudantes na Reserva Técnica do MAUC. Foto: Pajarito Pajarito. 


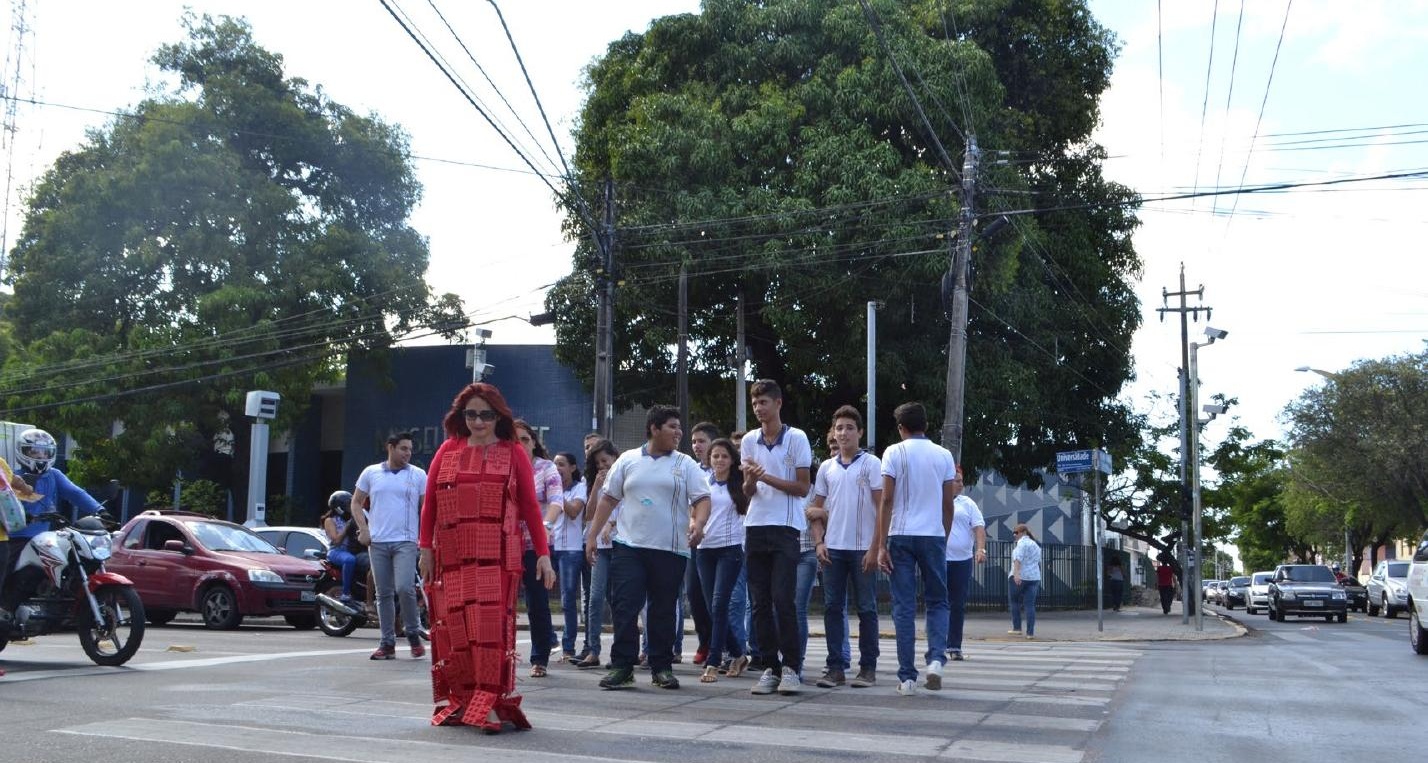

Figuras 6 e 7 - Retalhistas: eu e os Outros, 2015. Fotos:Paloma Pajarito.

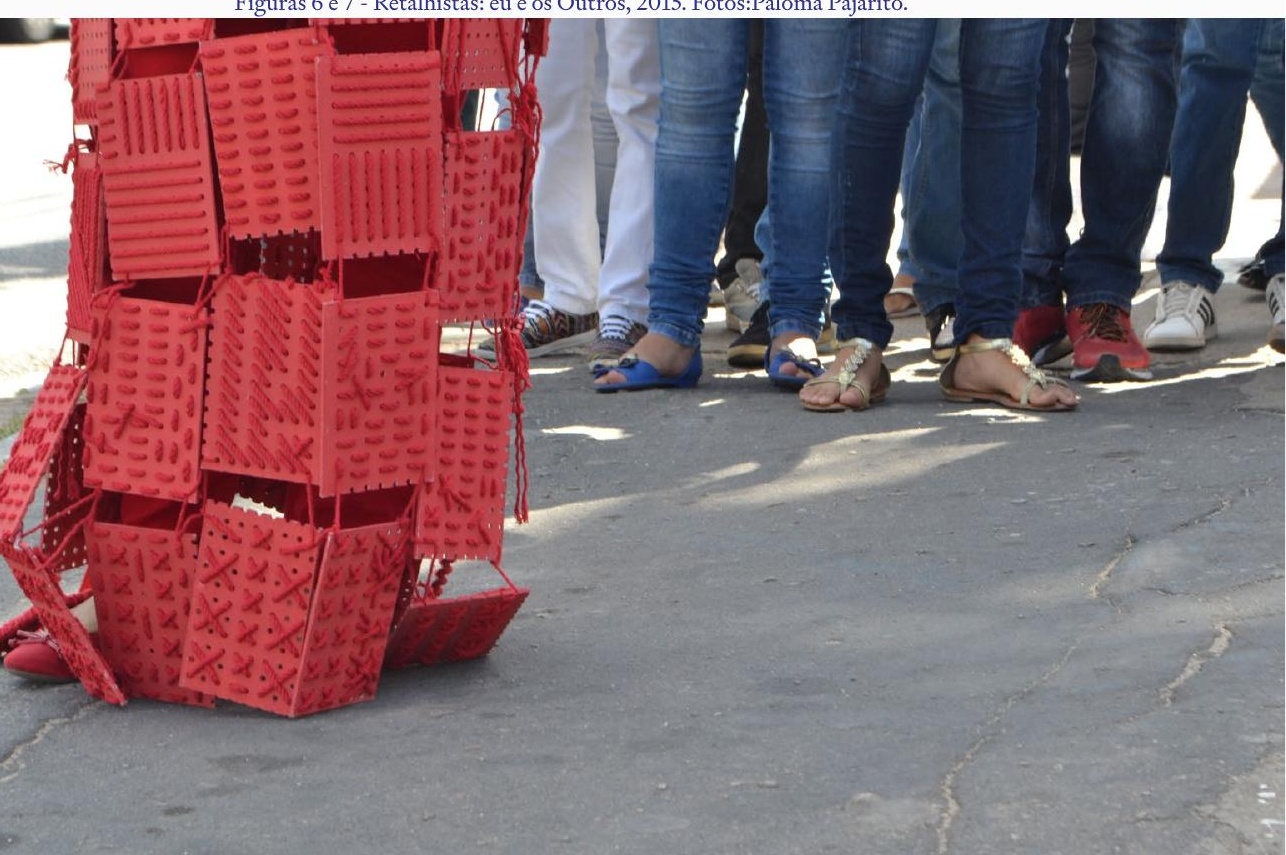


As imagens supracitadas mostram um pouco desse momento e da realização da performance nas ruas da cidade de Fortaleza.

Por último, apresento registros fotográficos da Performance "Narrativas poéticas de pesquisas", realizada em 2017, na ocasião do lançamento o Livro/ebook "Na aldeia, na escola e no museu: alinhavos entre infância e trabalho docente"4, do Grupo de Pesquisa Ludicidade, Discurso e Identidades nas Práticas Educativas - LUDICE. Coordenado pela professora Dra. Fátima Vasconcelos. Durante alguns meses solicitei aos integrantes do grupo, textos, imagens ou questões de suas pesquisas de trabalho de Conclusão de Curso (TCCs), de Mestrado e Doutorado, para a elaboração de uma indumentária. Os textos foram impressos em 69 pedaços de tecidos que, juntos compõem a poética da obra.

A presença do OUTRO/A marca estas três performances. O corpo como lugar de narrativa visual e de encontro com a Outridade é parte constitutiva da obra. A indumentária como segunda pele é outro componente que constitui minha poética visual. 


\section{REFERENNCIAS}

BOURRIAUD, Nicolas. Estética Relacional. São Paulo: Martins, 2009.

DELEUZE, Gilles; GUATARI, Félix. Mil Platôs: capitalismo e esquizofrenia 2. Vol. 1. São Paulo: Editora 34, 2011. (Coleção TRANS).

DELEUZE, Gilles; GUATTARI, Félix. Mil Platôs: capitalismo e esquizofrenia 2. Vol. 3. São Paulo: Editora 34, 2012 (Coleção TRANS).

DELEUZE, Gilles. Espinosa: filosofia prática. São Paulo: Escuta, 2002
DE CERTEAU, Michel; GIARD, Luce; MAYOL, Pierre. Os fantasmas da cidade. In: De Certeau, Giard e Mayol. A invenção do cotidiano 2. Morar, cozinhar. Petrópolis, RJ: Vozes, 2009.

MELIN, Regina. Performance nas artes visuais. Jorge Zahar Ed., 2008

STALYBRASS, Peter. O Casaco de Marx: roupas, memória, dor. Traduzido por Tomaz Tadeu. 3 ed. Belo Horizonte: Autêntica, 2008.112 p. - (Coleção Mimo)

\section{FONTE ON-LINE}

MACHADO, Marina. A Criança é Performer. Revista

Educação e Realidade, vol, 35, n.2. maio/ago. Universidade Federal do Rio Grande do Sul - UFRGS, 2010. Disponível em: https://seer.ufrgs.br/educacaoerealidade/article/view/11444/9447. Acessado em 13 de fev. 2020. 


\section{Patrícia da Silva Martins}

\section{O ENSINO DO DESENHO COMO EXPERIÊNCIAS PRÁTICAS E CONCEITUAIS}

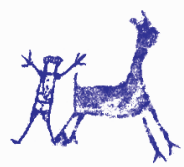

A experiência ocorre continuamente, porque a interação do ser vivo com as condições ambientais está envolvida no próprio processo de viver. (DEWEY, p.109).

Segundo Larrosa ${ }^{1}$ (2004) experiência é "o que nos passa", é "o que nos acontece", ou o que nos toca. A cada dia passam muitas coisas, porém, ao mesmo tempo, quase nada nos passa.

...a experiência é cada vez mais rara por falta de tempo. Tudo o que passa, passa demasiadamente depressa, cada vez mais depressa. E, com isso, reduz-se a um estímulo fugaz e instantâneo que é imediatamente substituído por outro estímulo ou por outra excitação igualmente fugaz e efêmera. $\mathrm{O}$ acontecimento nos é dado na forma de choque, de estímulo, de sensação pura, na forma de vivência instantânea, pontual e desconectada. (LARROSA, 2004, p.157).

Em sala de aula o tempo também é muito escasso para tantas demandas a serem realizadas. Concordo com a ideia de Larrosa: "Somente o sujeito da experiência está, portanto, aberto a sua própria transformação" (LARROSA, 2004, p.157). Por isso, penso que a sala de aula é o espaço onde podemos vivenciar momentos transformadores, enquanto professores, enquanto alunos, para isso é preciso estar aberto ao novo, atentos ao que nos acontece. Em nosso dia a dia, muitas vezes não

\footnotetext{
${ }^{1}$ Jorge Larrosa Bondia é professor da Universidade de Barcelona e doutor em Filosofia da Educação. Disponível em:<https://portal.aprendiz.uol.com.br/arquivo/2013/04/09/o-papel-da-educacao-e-subverter-as-regras/>. Acesso em: 02 jan. 2021.
} 
paramos para refletir sobre o que acontece no ambiente escolar, não oportunizando um momento de parada e de reflexão. Assim, penso que só viveram uma experiência aqueles que se permitirem vivenciar.

A experiência, a possibilidade de que algo nos passe ou nos aconteça ou nos toque, requer um gesto de interrupção, um gesto que é quase impossível nos tempos que correm: requer parar para pensar, para olhar, parar para escutar, pensar mais devagar, olhar mais devagar e escutar mais devagar; parar para sentir, sentir mais devagar, demorar-se nos detalhes, suspender a opinião, suspender o juízo, suspender a vontade, suspender o automatismo da ação, cultivar a atenção e a delicadeza, abrir os olhos e os ouvidos, falar sobre o que nos acontece, aprender a lentidão, escutar os outros, cultivar a arte do encontro, calar muito, ter paciência e dar-se tempo e espaço. (LARROSA, 2004, p.160)

Uma vez ouvi uma frase de um amigo: "aquele que fala é o primeiro que ouve"; nunca mais esqueci suas palavras e assim acho que também acontece com a docência, aquele que ensina é quem primeiro aprende. O professor precisa conhecer a linguagem do desenho para tornar possível o compartilhamento de experiências e saberes. A linguagem do desenho é muito vasta tem ramificações em diversas possibilidades, sejam conceituais, técnicas, processuais. Gosto de pensar que o próximo desenho sempre será o melhor, já que à medida que você vai estreitando laços com essa linguagem vai enriquecendo cada vez mais seu repertório, seu fazer. A partir disso concluo que os docentes precisam sempre estar em um estado de experiência, em um estado de encantamento, disposto a aprender com um olhar sensível às questões do nosso cotidiano escolar. Afinal o espaço da sala de aula é um dos espaços possíveis a experiência estética, nas falas, nas ações compartilhadas. E assim reflito sobre minha própria prática; será que estou desenvolvendo atividades ou experiências? Será que em minhas aulas os alunos estão vivenciando experiências significativas?

A rotina escolar pode nos levar a um fluxo automático, onde a aula pode acabar se reduzindo a: fazer chamada; colocar atividades na lousa; explicar o conteúdo; dar visto nas atividades; marcar atividades realizadas na caderneta. Encerra se o tempo da aula e começamos tudo novamente em outra sala. O que aconteceu de singular nesse espaço de tempo de uma ou duas aulas? Posso pensar em vários fatores que contribuem para esse automatismo didático, mas não quero fazer deste texto um muro das lamentações. Se perguntarmos a qualquer professor com certeza eles apresentaram uma lista de queixas de sua profissão. O que mais me inquieta é pensar em que momento aquela aula cansativa, monótona se torna uma experiência singular. Muitas vezes nem nos damos conta do que realmente se passa em nossa aula, não pensamos em nossas vivencias a não ser que sejamos questionados pelos outros. Será que existem outras possibilidades, outras propostas, outras ferramentas mais 
eficazes na construção de experiência mais significativas? Talvez a partir da minha prática possa apontar algumas alternativas que deram certo em minha prática, mas que também podem não dar certo para outros professores. Aqui está a chave para a "experiência", mesmo que eu descreva nos mínimos detalhes o que deve ser feito outro professor pode seguir a risca e ao fim não chegar ao resultado esperado. Pois a sala de aula é o lugar das singularidades, das diferenças e, cada aluno, cada momento é único. O foco não deve estar no aluno, muito menos no professor, mas na relação entre estes indivíduos na construção do processo de ensino/aprendizagem. Estar disposto a cancelar um plano de aula para ouvir o aluno deve fazer parte deste processo, já que entendo que o conteúdo pode ser acessado pelo discente por meio da internet. Será que, o que nos cabe não é somente orientar, para que consigam reunir essas informações, estabelecer relações levando-os a uma compreensão que possa ser aplicada em sua vida?

O sistema educacional permite poucas oportunidades para buscas contemplativas, erroneamente assumindo que elas são improdutivas. Seria bom, por exemplo, se na prática do desenho, o olhar, o apreciar, o contemplar fizesse parte do processo de ensino. Parar para ver o que há de potencial nas produções, pode propiciar encontros, perguntas, processos diferentes em diferentes tempos e espaços, o docente pode compartilhar com o discente a construção da sua aprendizagem e colocar o seu processo criativo enquanto material de reflexão dentro da sala de aula. Com isso pode ajudar a desenvolver a autoconfiança do aluno.

A sala de aula deve ser o lugar da reflexão, cada proposta de ensino de desenho é um mistério a ser descoberto, pois nem sempre encontramos respostas únicas ou certas, pode haver muitas respostas possíveis. $\mathrm{E}$ as aulas que haviam sido planejadas podem ganhar nova roupagem a partir da interação com os alunos, mas cabe ressaltar que, para que isso aconteça o professor precisa dominar os temas que quer abordar e conhecer seus discentes. Dentro de uma aula de Arte pode existir um universo de possibilidades: podemos promover um aprendizado experiencial; explorar questões interdisciplinares; ter estudo autodirigido; trabalho coletivo onde existe a troca de ideias não hierárquicas; pode ser o momento de compartilhar com os outros uma prática artística. A sala de aula pode ser o lugar de encontro entre professor e aluno; entre aluno e aluno. Um espaço de encontro, de atravessamentos.

Durante o desenvolvimento da linguagem do desenho não devemos nos perder na burocracia, enquanto professores convivemos com as obrigações institucionais, mas nosso foco deve estar em estimular e fazer desabrochar as habilidades individuais de cada um.

A instrumentalização do educador requer a vivência da linguagem gráfica, pois constatam-se lacunas na formação, seja pelo sistema escolar, seja por impedimentos de ordem familiar, social e cultural. A vivência prática propicia ao educador mais perguntas, confrontos, espelhamentos, deli- 
neando possibilidade quando se tem à mão novos repertórios gráficos, que atualizam e preenchem esses vácuos em nossa formação.( DERDYK, 2020, p. 21) $)^{2}$.

E qual o problema em nos arriscarmos em campos que não conhecemos? O professor também aprende com seus alunos, aprende vivenciando sua aula. Isso não significa que vamos chegar na sala e, ao acaso vamos ministrar nossa aula, mas que durante as aulas podem surgir ideias novas, que podem ser levadas em consideração para reformulação do planejamento ou mudança de abordagem das próximas aulas.

Existe um percurso mental antes de a pessoa executar seu fazer artístico, seu fazer desenhista, é importante um pensar antes do percurso físico, antes da materialização das ideias. Em sala percebo que em muitas ocasiões para os alunos o ato de desenhar se reduz a uma mão que consegue traçar linhas, riscos que formam imagens reconhecidas pelos colegas. No entanto essa mão esta ligada a um corpo, uma mente, a pensamentos e emoções. Quando o aluno desenha, ele já incorporou uma serie de conhecimentos traduzindo-os em linhas e formas. O pensar, ouvir, escutar, imaginar, o fazer imaterial também faz parte da aprendizagem da linguagem do desenho, mesmo que não estejamos fazendo na prática a reflexão sobre a linguagem vai reverberar na prática do desenho.

Nós precisamos vivenciar o desenho e também falar sobre essas vivências. Quando relatamos uma experiência estamos pensando sobre ela, para poder relatar. Você mergulha em seu processo, buscando entender conceitualmente o fazer, redirecionando melhor a prática. Se não pensarmos, se não relatamos a experiência se esvai.

Relatar sobre a produção de desenho exercita a memória, pode autenticar, legitimar sua experiência com o outro, com sua própria experiência com a linguagem do desenho. O relato, o registro do processo em si é uma experiência que muitas vezes não é explorado. Quando se fala em desenho é comum ouvirmos "desenho se aprende desenhando"; concordo, mas penso que vai muito além disso. Para que haja uma experiência com o desenho é preciso ver desenhos de diferentes tipos, com diversas técnicas, opinar, argumentar, falar sobre desenho, só assim criamos um repertório, desenvolvemos uma prática de aprendizagem significativa. Assim levamos nossos alunos a ter um repertório, a pensar sobre as infinitas possibilidades da linguagem do desenho, levando-os a buscar a forma que mais lhe facilite a desenhar. Assim o desenho estará presente no olhar, por meio de nossas mãos o desenho se torna uma extensão de nossas ideias.

\footnotetext{
${ }^{2}$ Edith Derdyk nasceu em São Paulo, em 1955. Fez o curso de Licenciatura em Artes Plásticas pela FAAP (1977/1980). É artista plástica, ilustradora e educadora. Disponível em: < https://www.guiadasartes.com.br/edith-derdyk/obras-e-biografia > Acesso em: 02 jan. 2021.
} 
Quando experimentamos o falar sobre o desenho, vivenciamos uma experiencia conceitual. Precisamos elaborar internamente o que pensamos para deixar claro para que os outros entendam nosso ponto de vista. Quando externamos nossos pensamentos temos um embate com o outro. O outro por sua vez pode concordar ou discordar totalmente de nossas concepções de desenho, levando-nos a pensar diferente ou a buscar mais argumentos para sustentar o que pensamos, enriquecendo nossas reflexões que irão refletir na prática.

O desenho vai ser a mediação entre duas experiências; A primeira é a visual de quem desenha que abarca o que o desenhista está vendo, o que entende como desenho; A segunda é a experiência que resultará do seu desenho, o que pretende criar no olhar do observador. Assim o desenho é uma forma de investigação do mundo e uma maneira de refletir e elaborar plasticamente o conteúdo da experiência.

Por meio do desenho codificamos algo tridimensional em bidimensional, criando esquemas que levam a entender o que é o objeto. Criamos formas, organizando nossa experiência visual para que outras pessoas possam interpretar. Em um desenho de um objeto, por exemplo; você vê o objeto, interpreta esse objeto, tem uma experiência visual com ele. A intenção do desenhista será recriar essa experiência no olhar do observador futuro. Para recriar essa experiência o desenhista cria esquemas por meio de linhas, manchas, que ativam essa experiência perceptiva em quem vai olhar esse desenho.

Para desenhar é preciso o desejo e, saber lidar com os erros, as errâncias que a linha provoca. É preciso ver o acaso como companheiro, você absorve o acaso, faz associações com seu repertório e cria uma lógica interna para pensar sobre a experiência para que ela não vá embora.

"[...] A arte celebra com intensidade peculiar os momentos em que o passado reforça o presente e em que o futuro é uma intensificação do que existe agora.” (DEWEY, 2012, p.82) ${ }^{3}$. O entusiasmo pelo desenho nasce com a nossa experiência ao desenhar, ao ver desenhos, vamos reatualizando o que conhecemos. Assim o desenho é um estado de acontecimento. No desenho de observação, por exemplo, o objeto está na nossa frente enquanto desenhamos, o ver e o desenhar acontecem ao mesmo tempo. Se não observamos não vamos ter memória. Para Duarte ${ }^{4}$ “[...] realizar uma aprendizagem significa ser capaz de conhecer o mesmo objeto sempre

\footnotetext{
${ }^{3}$ John Dewey (1859-1952) foi um filósofo e educador americano que ajudou a fundar o pragmatismo, uma escola filosófica de pensamento popular no início do século XX. Ele também foi fundamental no movimento progressista na educação. Disponível em: < https://escolaeducacao.com.br/john-dewey/> Acesso em: 02 jan. 2021.

${ }^{4}$ Maria Lúcia Batezat Duarte possui graduação (licenciatura) em Artes Plásticas pela Universidade Federal do Rio Grande do Sul (1980), mestrado em Ciências da Comunicação pela Universidade de São Paulo (1989), doutorado em Artes pela Universidade de São Paulo (1995) e pós-doutorado na Université Paris-1, Sorbonne (2006). Disponível em: <http://lattes.cnpq.br/2670000362289218>. Acesso em: 02 jan. 2021.
} 
que ele estiver novamente ao alcance de alguma modalidade sensorial e seja então percebido e identificado." (2011, p. 20).

Desenhar é observar, é captar, capturar o mundo a nossa volta.

[...] Desenhar pode envolver a memória procedural, a memória visual ou diversas combinações entre elas. A memória procedural refere-se ao procedimento gráfico-motor, que resulta de um automatismo gráfico, isto é, da repetição constante de um mesmo desenho, e a memória visual utiliza o córtex visual ao ativar imagens mentais do objeto real. (DUARTE, 2011, 2011b, p. 87).

Enquanto observamos estamos entrando em contato com a memória, guardando aquilo que vemos, guardando também a forma como registramos o que observamos no papel.

Utilizo a expressão memória do corpo - ainda que seja consciente de não estar me referindo exatamente a um conceito de memória comum, mas uma nova maneira de entender como o corpo se ajusta aos instrumentos e se expressa no espaço/tempo - por uma percepção minha de que o corpo do desenhista se constrói em meio a um processo geral de suas partes [...] (MENEZES, 2010, p.53). ${ }^{5}$

O ato de desenhar está estreitamente relacionado com o pensar e o fazer. Menezes (2010) diz que "[...] o desenho de memória é a memória de nossa própria experiência de desenho [...] seria mais adequadamente chamado de "memória de desenho"“. (p.53).

Talvez o grande desafio para quem quer aprender a desenhar esteja no olhar. Desenhar não só o que a gente vê, mas desenhar aquilo que a gente não vê.

[...] aprender a olhar aquilo que já se vê. A dificuldade de se perceber os elementos visuais, sobretudo diante de outras pessoas que são capazes de fazê-lo, costuma gerar nos sujeitos a impressão de um embaraço de uma limitação pessoal, ou seja, não ser capaz de olhar para aquilo que se apresenta à sua frente. (MENEZES, 2010, p.175)

\footnotetext{
${ }^{5}$ Fernando Chuí de Menezes é artista plástico, músico e arte-educador. Possui doutorado em educação pela FEUSP, mestrado em artes visuais pela UNESP e graduação em Artes Plásticas (Licenciatura Plena - Fundação Armando Álvares Penteado). Disponível em: < https://www.escavador.com/sobre/2819544/fernando-chui-de-menezes>. Acesso em: 02 jan. 2021.
} 
Em muitas ocasiões não estamos atentos ao mundo a nossa volta, o que vemos não é o que está diante dos nossos olhos. Apropriamo-nos de algumas imagens que encontramos ao longo de nossas vidas, como por exemplo, posso citar o famoso desenho de casas com suas chaminés, em algum momento utilizamos esse desenho para resolver uma proposta gráfica e ele foi bem aceito, por isso em vez de criar desenhos de novas casas utilizo aquela que ficou registrada na minha "memória de desenho", como desenho de uma casa. Na verdade, a imagem está dada, não vemos, só reconhecemos aquilo que pensamos que vemos. Inicialmente não nos damos conta das experiências visuais que estamos passando, o que vemos é o que já sabemos, uma imagem puramente associativa, isso é um mecanismo do olhar, substitui uma imagem nova por uma já conhecida que seja semelhante. Faz isso para economizar energia, porque demanda energia fazer o mapeamento de uma nova imagem e ainda corremos o risco dessa imagem, desse desenho não ser visto como uma casa.

Tudo que vamos desenhar é sempre inédito. Porque o mundo está em constante transformação, para conseguir olhar de fato é preciso tentar desconstruir esse processo de substituição por algo conhecido, e estar com atenção a todo o momento, estar com a visão ativa para o momento presente. Por isso a importância de acordar o corpo para a percepção do mundo, se colocar como se fosse a primeira vez.

O desenhista não reproduz a realidade, uma vez que o desenho não é uma atividade meramente mecânica e automática. Ele recria experiências visuais. Apesar de observar muita coisa, ele seleciona os elementos capazes de replicar uma experiência visual específica. Em outras palavras, a visão do desenhista é um exercício permanente de síntese, em que ele abstrai e exclui elementos que não interessam. E inclui outros elementos que não estão em cena. Assim, consegue alterar a realidade para que ela pareça mais verossímil.

Quando se desenha, um ou outro desenho sai errado e, qual o problema disso? Qual o problema em fazer um desenho errado, um desenho feio? Além disso, quem define o que é certo ou errado? Posso fazer um desenho e achar lindo, enquanto outra pessoa pode olhar e dizer que está feio, torto, deformado. Nesse sentido mais uma vez a importância de compreender as concepções de desenho de nosso aluno. Ao desenhar tudo pode dar errado. E qual o problema disso? Já que isso pode me levar a buscar o êxito. Pensar só nos desenhos perfeitos pode acabar limitando as possibilidades. Talvez se oferecermos exemplos de desenhos que pelos olhos dos alunos são errados, "olha isso não funcionou para esse tipo de desenho, vamos pensar porque não funcionou?” Discutir sobre esses desenhos pode ser uma possibilidade para levar o aluno a atingir o desenho que deseja realizar e diz não saber.

Insegurança como método, fracasso como método. Errando muito, aprendemos mais, a disponibilidade para o erro pode trazer muitos ganhos. Onde há muita dúvida há também muita vontade de saber. Aquilo que não sei me diz mais sobre aquilo que quero aprender. 
Alguns alunos reclamam que não sabem desenhar, que seu desenho está errado, isso ocorre porque em sua mente existe um imaginário de que o bom desenho é aquele que reproduz melhor a realidade, desenhos extremamente realistas detalhados. Essa concepção de desenho foi criada a partir da Missão Artística Francesa, que chega ao Brasil em 1816, trazendo os conceitos neoclássicos inspirados nos conceitos gregos e renascentistas. Tais ideias ecoam até hoje na escola. Por isso antes de qualquer coisa é preciso conhecer o que o nosso aluno pensa sobre desenho, assim podemos falar sobre o que está "estranho" no desenho, onde ele "errou", incorporando o erro construtivamente levando-o a entender o que necessita para desenhar como quer. Além disso, precisamos alargar a visão de desenho do aluno, pois o desenho pode apresentar milhares de possibilidades. Ampliando seu repertório podemos leva-lo a perceber que aquilo que a princípio era um erro pode se tornar um detalhe importante para outros tipos de desenho.

[...] A experiência, na medida em que é experiência, consiste na acentuação da vitalidade. Em vez de significar um encerrar-se em sentimentos e sensações provados, significa uma troca ativa e alerta com o mundo; em seu auge, significa uma interpretação completa entre o eu e o mundo dos objetivos e acontecimentos. (DEWEY, p.83)

O processo criativo cria um deslocamento do aluno em relação a ele e em relação ao que observa ao que desenha, não é que vamos mudar a vida do aluno, mas vamos ampliar sua visão de mundo. Como aquele corpo traça aquele movimento, que faz com que traduza o modo de ser, pensar e estar no mundo ao longo dos séculos. "Os significados são extraídos de experiências anteriores, inclusive do condicionamento cultural.” (DEWEY, p.39). O desenho é o registro da nossa capacidade de ver e existem singularidades na forma de perceber o tempo o espaço, são muitos os atravessamentos. Por isso penso que existe uma infinidade de tipos e formas de desenho.

"[...] As coisas percebidas têm "significados acumulados"; na experiência estética, tanto as qualidades sensoriais quanto os significados ideativos se intensificam e se aprofundam.” (DEWEY, p.40). Por isso a importância de compartilhar a experiência sobre desenho em sala de aula. Já que, o que eu desenho, o que vejo, sempre perpassa o meu imaginário. Para o ensino vai ser preciso o deslocamento ao encontro com o outro. O que meu aluno entende por desenho? O que sabe desenhar? O que eu tenho para ampliar o que ele já tem ou quer aprender? Pensando sobre isso no ambiente escolar o ensino do desenho se torna um jogo de cumplicidade. Essa cumplicidade se dará com a participação do aluno como protagonista em seu processo de ensino aprendizagem, ampliando ainda mais a responsabilidade do professor já que para isso terá que também estar sempre se atualizando para melhor atender seus alunos. 
O prazer em desenhar é indispensável para seu ensino/aprendizagem, mas não quero dizer de um fazer por fazer, onde o aluno faz o que quer, mas trazer as instâncias do desenho, discussões que partem daquilo que o aluno já sabe ou precisa aprender. Para isso penso que seja necessário o espaço da escuta e a partir dela traçar as competências e habilidade para o desenho em duas instâncias: Primeira mais dirigida às intenções e gosto do aluno, instigando motivando a querer aprender; Segundo, mais geral, ampliando o repertório do aluno, mostrando que podem existir outras possibilidades além daquelas que já conhecem.

\section{REFERÊNCIAS}

DERDYK, Edith. Formas de Pensar o Desenbo: O Desenvolvimento do Grafismo Infantil. 3ed. São Paulo: Panda Educação, 2020.

DEWEY, John. Arte como experiência. São Paulo: Martins Fontes, 2012.

DUARTE, Maria Lúcia Batezat. Desenbo infantile seu ensino a crianças cegas. Razóes e método. Curitiba: Insight, 2011a.

DUARTE, Maria Lúcia Batezat; Mari Ines Piekas. Desenbo infantil empesquisa: imagens visuais e táteis. Curitiba: Insight, 2011b.

LARROSA, Jorge. Linguagem e educação depois de Babel. Belo Horizonte: Autêntica, 2004.
MENEZES, Fernando Chuí de. Uma bistória íntima do desenbo: sobre experiências de formação do desenho e dos desenbistas. São Paulo: Unesp, 2010. 202 f. Dissertação (Mestrado em Artes Visuais - Ensino e Aprendizagem da Arte) - 672 Instituto de Artes, Universidade Estadual Paulista "Júlio de Mesquita Filho” - Unesp, São Paulo, 2010. Disponível em: < https://repositorio.unesp.br/bitstream/handle/11449/86911/menezes_fc_me_ia.pdf?sequen$\mathrm{ce}=1$ \&isAllowed $=\mathrm{y}>$ Acesso em: 22 mai. 2020. 


\section{Tânia Maria de Souza França e José Álbio Moreira de Sales HISTÓRIAS DE VIDA TECIDAS COM ARTE E EDUCAÇÃO: A EXPERIÊNCIA FORMATIVA DO GRUPO DE PESQUISA IARTEH}

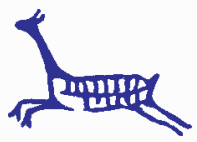

PREPARANDO O VOO - "VOAR EM BANDOS"

A crônica A conferencia dos pássaros, da escritora cearense Socorro Acioli, no seu livro sobre os felizes, serviu-nos de inspiração para a escrita desse artigo. Na mencionada peça literária, ela conta a "história de quando as aves estavam sofrendo com tanta revolta e disputas no mundo" e resolveram viajar em bando em busca de respostas. E a autora conclui dizendo que "Estamos mesmo perdidos nesse século dos absurdos e só nos resta voar em bandos, para pensarmos juntos nas estratégias de sobrevivência" (2019, p. 76).

É acerca de voarmos em bandos em busca de estratégias de sobrevivência na e com Arte, que queremos trazer nesse artigo a experiência do Grupo de Pesquisa Investigação em Arte, Ensino e História - IARTEH, na sua dimensão formativa, ao conectar histórias de vidas tecidas com Arte e Educação, reforçando que ao voarmos juntos podemos e somos MAIS.

O IARTEH funciona no Centro de Educação, vinculado ao Programa de Pós-

-graduação em Educação - PPGE/UECE, na linha de pesquisa Formação, Didá- tica e Trabalho Docente, no núcleo Arte, Memória e Formação, com registro no CNPq desde 2012. Como é usual, os grupos de pesquisa são criados com o intuito de auxiliar na efetivação de investigações em desenvolvimento, institucionalização e agrupamento de interesses de uma mesma área temática, a fim de favorecer a produção e a difusão de ideias da referida área. No caso do IARTEH, nosso estudo se desenvolve na interface Educação e Arte e vai além dessa perspectiva usual, uma vez que a narrativa estética e poética, utilizando-se de múltiplas linguagens, se faz presente nesta conexão. 
O Grupo tem como objetivo congregar pesquisadores que atuam no ensino de Arte, no âmbito da Universidade Estadual do Ceará (UECE), além de alunos e ex-alunos de mestrado e doutorado do Programa de Pós-graduação em Educação (PPGE), como também intenciona sedimentar as pesquisas já realizadas em Arte e Ensino de Arte, desde 2006, quando é defendida a primeira dissertação do Nú- cleo. Desde o seu nascimento, desenvolve um trabalho que busca a reflexão na ação em pesquisa, por meio dos encontros mensais de estudo, das monografias, dissertações e teses gestadas em profícuos diálogos reflexivos, em inter-relação com narrativas de histórias de vida dos seus membros, tecidas com Educação e Arte.

No seu início estava organizado em duas linhas de pesquisa: Artes Visuais, pa- trimônio e mediação cultural, arquitetura escolar e ensino de arte; e ensino de música e formação docente, que se articulavam no seu fazer e saber. Atualmente, continua com duas linhas de pesquisa: Artes Visuais, patrimônio e mediação cultural, arquitetura escolar, e ensino de Arte; e Arte-educação, saberes e Formação Docente. Releva expressar o fato que os participantes se vinculam às distintas linguagens artísticas - teatro, dança, artes visuais, fotografia, música - e atuam na fronteira Educação/Arte, não de uma maneira excludente, mas compreendendo a interface dessas duas áreas do conhecimento, buscando sempre um diálogo subjetivo e sensível. Barbosa (2009) corrobora essa ideia quando ensina que:

A arte não está isolada de nosso cotidiano, de nossa história pessoal. Apesar de ser um produto da fantasia, da imaginação, a arte não está separada da economia, política e dos padrões sociais que operam na sociedade. Ideias, emoções, linguagem diferem de tempos em tempos, de lugar para lugar, e não existe visão desinfluenciada e isolada. (P. 20)

Com efeito, esperamos contribuir com base nas práticas realizadas no Grupo, para ampliar as discussões sobre o ensino de arte, sua história e pesquisas em distintas linguagens e contextos, onde agem os fenômenos artísticos, como os espaços escolares e os ateliês livres; com as discussões sobre a formação docente em arte, para a educação básica e superior, especialmente no que se refere às licenciaturas; e para estabelecer intercâmbio com outros grupos que contemplem como objeto de estudos e investigação, aspectos da didática e prática de ensino de Arte, bem como a formação em Arte e cultura do cidadão e do professor da Educação Básica e Superior.

\section{ALGUMAS EXPERIÊNCIAS DE VOOS "PENSANDO JUNTOS NAS ESTRATÉGIAS DE SOBREVIVÊNCIA"}

É com o intuito de "pensarmos juntos estratégias de sobrevivência”, que indicamos nesta seção o modo como o Grupo se organiza, trazendo algumas práticas de ma- 
neira reflexiva. A dinâmica de funcionamento ocorre por meio de encontros quinzenais ou mensais de seus membros para estudar temas diversos relacionados com a senda Educação e Arte, Ensino de Arte, interligados por uma temática central, que permeia os estudos de cada semestre e tem relação com os temas de pesquisa. A organização e a escolha dos temas e dos mediadores são feita de modo participativa, colaborativa e democrática na primeira reunião do semestre.

Dentre as temáticas estudadas, mencionamos: Arte contemporânea e as diversas linguagens artísticas na contemporaneidade, Patrimônio cultural, Educação estética, experiência estética, arte como experiência, estética relacional, literatura de Cordel, partilha do sensível, Áudio descrição e imagens. E por compreender que não há um saber acabado, mas que o conhecimento "[...] é um processo de transformação contínua. [...] é transitório porque ele está em processo de construção e reconstrução" (PARERA, 2017, p. 352), essas temáticas, de uma maneira circular, se renovam nas discussões do grupo à proporção do tempo. Outra temática recorrente é o estudo sobre metodologia de pesquisa (A/R/TOGRAFIA, bricolagem, Pesquisa baseada em arte, Pesquisa-ação, pesquisa narrativa, (auto)biografia), por acreditarmos, como diz Parera (2017, p. 354), que "[...] muitas vezes, diferentes abordagens metodológicas podem ser complementares em um estudo, compensando eventuais deficiências de um ou outro método. Assim, os olhares que oferecem diferentes métodos podem ser perfeitamente complementares". De tal maneira a multirreferencialidade tem lugar nos estudos do grupo.

A estratégia metodológica de estudo e inserção nas discussões das temáticas no grupo, são os diálogos reflexivos. Essa metodologia tem apoio na abordagem de Paulo Freire, no diálogo como caminho para a humanização ou libertação. Consoante ensina Freire (2005, p. 93) "[...] a fé nos homens é um dado a priori do diálogo”. Para o autor, neste lugar de encontro, que é o diálogo, “[...] não há ignorantes absolutos, nem sábios absolutos: há homens que, em comunhão, buscam saber mais". O diálogo é o encontro amoroso entre as pessoas para ser mais, e a educação, como prática de liberdade, visa a abolir a dicotomia homem-mundo, levando-o a reconhecer “[...] entre eles uma inquebrantável solidariedade" (FREIRE, 2005, p. 95).

É nessa perspectiva que a cada início de semestre o primeiro encontro é de planejamento quando os temas são conduzidos por todos os membros e se formam duplas, trios que são responsáveis pela dinamização do diálogo reflexivo sobre o tema com os demais membros, no decorrer do semestre. Lembramos que o diálogo não há de ser entendido apenas como uma técnica ou tática, mas como algo que faz parte da nossa natureza histórica. Reforça Freire a ideia de que, por intermédio “[...] do diálogo, refletindo juntos sobre o que sabemos e não sabemos, podemos, a seguir, atuar criticamente para transformar a realidade" (FREIRE; SHOR, 1993, p. 123). É isso que tentamos fazer no grupo, em um movimento de rememorar e repensar nossas experiências, histórias de vida, interligando-as com as temáticas estudadas e as pesquisas em andamento e, com isso, os membros do grupo produzem "[...] um conhecimento 
sobre si, sobre os outros e o cotidiano, revelando-se através da subjetividade, da singularidade, das experiências e dos saberes" (ATAÍDE, SOUZA, MOTA, 2008, p. 55), dando ensejo á elaboração de artigos, capítulo de livros, artes visuais, performances.

Além dos estudos mensais, o grupo realiza visitas a espaços culturais, como ocorreu com a oficina de fotografia iniciada no Passeio Público e concluída na uni- versidade. Foi uma experiência estética significativa. Primeiro por estarmos dialo- gando com um espaço cultural que representa um patrimônio da cidade de Forta- leza; e, em segundo lugar, pela reflexão sobre a experiência em fotografar esse espaço com suporte nessas perguntas: O que você entende por patrimônio? Essa fotografia representa seu conceito de Patrimônio? O que essa fotografia representa para você? Como você trabalharia essa fotografia no ensino de arte? No momento de conclusão e sistematização, no encontro seguinte, na universidade, cada qual apresentou sua fotografia e refletimos, especialmente sobre o conceito de patrimônio, como algo polissêmico, complexo e o quanto as fotos anunciavam/ denunciavam um lado invisível do patrimônio, muitas vezes o lado do descuido, da desvalorização, outras vezes das marcas do tempo, da memória, nos fazendo pensar sobre a imagem fotografada e o real. Esta discussão expressou, ainda, a necessidade de um olhar crítico e provocador, desconstruindo, assim, a ideia de modelo, no contexto do ensino de arte.

Retiro estético é outra atividade desenvolvida pelo Grupo. Ele se caracteriza por um convite para que cada membro, com amparo na sua subjetividade e numa convivência mais próxima, realize, coletivamente, práticas de investigação e formação, inter-relacionando com narrativas de histórias de vida dos seus membros, tecidas com Educação e Arte. Realizamos um retiro estético, na cidade de Viçosa do Ceará, em outubro de 2016, que teve como programação um café com arte com as professoras do Patronato da cidade (colaboradoras e locus da pesquisa doutoral) e participação na culminância da atividade doutoral de um membro do grupo. Depois realizamos uma caminhada estética pela cidade, compreendendo o caminhar como modo de intervenção urbana (CARERI, 2013) pelo qual o corpo na sua inteireza ressignifica lugares; e culminamos com uma roda de conversa sobre a experiência, sentidos e significados para cada componente grupal, momento de sistematizar, reflexivamente, o vivido.

Ao analisarmos, hoje, a trajetória do grupo, percebemos que há duas Dimensões - investigativa e formativa - e que se aproximam da unidade de ideia pesquisa-formação, por compreendermos que a realização de uma busca no âmbito do saber parcialmente ordenado não se dá no vazio, mas inserida em histórias de vida e de formação, como nos ensina Josso (2010, p. 100) ao defender "a pesquisa-formação como prática da consciência da consciência”. Essa prática da consciência da consciência concretiza-se nos encontros mensais do grupo, quando as temáticas estudadas por meio dos diálogos reflexivos refletem as diversas pesquisas do grupo, plano stricto sensu de doutorado, mestrado e graduação, tornando esses encon- 
tros verdadeiras experiências formadoras, como relatado anteriormente. Para Josso (2004) as experiências formadoras:

São as experiências que podemos utilizar como ilustração numa história para descrever uma transformação, um estado de coisas, um complexo afe tivo, uma ideia, como também uma situação, um acontecimento, uma atividade ou um encontro. E essa história me apresenta ao outro em formas sócio-culturais, em representações, conhecimentos e valorizações, que são diferentes formas de falar de mim, das minhas identidades e da mi- nha subjetividade. Assim, a construção da narrativa de formação de cada indivíduo conduz a uma reflexão antropológica, ontológica e axiológica.(P.40,41)

Notamos os encontros do grupo como essas experiências formadoras pela fala de alguns membros no final dos encontros e anotadas no diário de formação de um dos autores: "Todo o meu viver está fazendo sentido nessa manhã", "Achei interessante perceber as várias visões sobre as imagens", "O questionamento nos faz refletir: como usar no ensino de arte", "Quero agradecer o diálogo que me opor- tunizou refletir sobre o meu trabalho", "Foi um ano muito legal. Só tenho que agradecer. Aprendo bastante", "A ida ao Passeio Público foi muito significativa. Esses são momentos de formação", "Foi um ano muito produtivo, os horizontes se ampliaram", "Momento do IARTEH é de grande importância para a nossa for- mação". Dewey, sobre o tema experiência, contribui com essa reflexão ao dizer que "a experiência, nesse sentido vital, define-se pelas situações e episódios a que nos referimos espontaneamente como "experiências reais" - aquelas coisas de que di- zemos, ao recordá-las 'Isso é que foi uma experiência'” (2010, P.118). E é assim que concebemos as práticas contemporâneas vividas pelos membros do Grupo, como experiências plenas, reais, que nos transpassam.

Relativamente à dimensão investigativa, na sua especificidade, de 2006 a 2011 foram defendidas cinco dissertações e de 2012, ano em que foi registrado o grupo, até o presente, foram sustentadas 13 dissertações e quatro teses de doutoramento. Essa realidade nos permite dizer que o grupo centra seus estudos nos domínios da pesquisa qualitativa, por considerar que essa abordagem permite trabalhar com os significados, fazendo múltiplas conexões, interpretações, relações com os variados contextos vividos pelo sujeito, mas permite que os seus pesquisadores transitem em várias modalidades de pesquisa e instrumentos de produção dos dados, expres- sando aqueles que mais se harmonizam ao objeto da sua pesquisa, conforme en- contramos: etnografia, estudo de caso, método historiográfico, história oral, história cultural, pesquisa-ação, entrevistas, observação, dentre outros.

Percebemos, contudo, que o uso da pesquisa-ação, passou a ser tendência dentro das pesquisas do grupo, prática já encontrada em quatro dissertações e nas três teses de doutorado, porque "[...] privilegia processos de intervenções que visam 
transformar determinada realidade, emancipando os indivíduos que dela participam" (IBIAPINA, 2008, p. 9). Consideramos relevante esse método, porque diz respeito a práticas concretas de pessoas em um determinado tempo e espaço e que se constitui em um processo de aprendizagem, conforme anunciam Kemmis e Wilkinson (2011, p. 44):

A pesquisa-ação é um processo de aprendizagem cujos frutos são as mudanças reais e materiais: Naquilo que as pessoas fazem; Em como interagem com o mundo e com os outros; Em suas intenções e naquilo que valorizam; Nos discursos nos quais entendem e interpretam o mundo.

Compreendemos, assim, a pesquisa-ação como estratégia para promover o desenvolvimento profissional, produzindo conhecimento, fundamentado no processo de reflexão-ação-reflexão de um modo cíclico e não linear.

\section{CONSIDERAÇÕES FINAIS: ALGUMAS REFLEXÕES SOBRE OS VOOS}

Como resultados, notamos que, por meio das atividades desenvolvidas o grupo contribui para qualificar as discussões sobre o ensino de arte, sua história e pesquisa em variadas linguagens e contextos nos quais os fenômenos artísticos, como os espaços escolares e os ateliês livres. O grupo tem afirmado, permanentemente, o seu espaço nas discussões sobre a formação docente em arte, para a educação básica e superior, especialmente no que se refere às licenciaturas. Revela-se, efetivamente, como espaço de formação para os seus membros, acolhendo a intersubjetividade da formação humana.

Ao analisarmos a trajetória do grupo verificamos que as duas dimensões, in- vestigativa e formativa, mesmo guardando a sua especificidade, estão sempre in- ter-relacionadas aproximando-se da expressão pesquisa-formação. E tendo a Pesquisa (auto) biográfica como suporte transversal e ao mesmo tempo as dissertações e tese escritas, essas produções se exprimem como elementos da biografia do grupo e seus integrantes.

É relevante dizer ainda da importância do grupo para a (co)formação do campo Educação e Arte, principalmente no que concerne à formação de professores, quando anunciamos que os alunos de mestrado e doutorado responsáveis pela elaboração das dissertações e teses, estão, de algum modo, vinculados ao ensino de Arte em seus quefazeres profissionais, seja na Educação Básica ou no Ensino Superior. Acrescentamos a isso a extensa produção escrita e publicada em eventos, livros, periódicos, jornais e revistas resultantes das investigações efetivadas e a possibilidade de reinvenção do Grupo nesse momento de pandemia que traz como consequência o distanciamento social. Os encontros aconteceram remotamente, sempre alicerçados pelo diálogo e criatividade. 


\section{REFERÊNCIAS}

ACIOLI, Socorro. Sobre os felizes. 1 ed - Fortaleza-CE : Dummar, 2019

ATAÍDE, Y. D. B; SOUZA, E. C.: MOTA, K, M. S. Do oral ao escrito: Gênese, trajetórias e narrativas do Grupo História Oral/GRAFHO. In: SOUZA, E. C.; PASSEGGI, M. C.; ABRAHÃO. M. H. M. Pesquisa (auto)biográfica e práticas de formação. Natal, RN: EDUFRN; São Paulo: Paulus, 2008.

BARBOSA, A. M. A imagem no ensino da arte. 7. ed. São Paulo: Perspectiva, 2009

CARERI, Francesco. Walkscapes: o caminhar como prática estética. I ed. São Paulo : Editora G. Gili, 2013

DEWEY, J. Arte como experiência. São Paulo: Martins Fontes, 2010.

FREIRE. P Pedagogia do Oprimido. Rio de Janeiro: Paz e Terra, 2005.

FREIRE, P.; SHOR, I. Medo e Ousadia. O cotidiano do professor. 5. ed. Rio de Janeiro: Paz e Terra, 1993.
IBIAPINA, I. M. L. de M. Pesquisa colaborativa: investigação, formação e produção de conhecimentos. Brasília: Líber Livro Editora, 2008.

JOSSO, M. C. Experiências de vida e formação. São Paulo: Cortez, 2004.

KEMMIS, S.; A pesquisa-ação participativa e o estudo da prática. In: PEREIRA, J. E. D.; ZEICHNER, K.. M. (Orgs). A pesquisa na formação e no trabalho docente. Belo Horizonte: Autêntica, 2011, p.39-59.

MORIN E. Introdução ao pensamento complexo. Porto Alegre: Sulina; 2006.

PARERA, M. G. O teatro como processo de formação. In: MARTINS, R.; TOURINHO, I.; SOUZA, E. C. (orgs). Pesquisa Narrativa: interfaces entre história de vida, arte e educação. Santa Maria: Ed da UFSM, 2017. 
ANA ANGÉLICA ALBANO

Professora Efetiva da Universidade do Estado de Minas Gerais - Escola Guignard. Doutora em Educação pela Unicamp. Mestre em Literatura e outras artes pela UFMG. Licenciada em Educação Artística pela UEMG; Licenciada em Letras pela UFMG. Possui experiência como pesquisadora e docente nas áreas de: Ensino de Arte, Processos de Criação, Autobiografia, Cerâmica, Formação de Professores de Artes Plásticas e Visuais, Arte e Saúde Mental, Arte e Infância. Foi ainda coordenadora, de 2013 a 2017, do Programa Instituci

\section{EDITE COLARES}

Possui graduação em Pedagogia pela Universidade Federal do Ceará (1990), mestrado em Educação Brasileira, pela Universidade Federal do Ceará (1997), doutorado em Educação Brasileira, pela Universidade Federal do Ceará (2008). É PhD pela Faculdade de Belas Artes da Universidade do Porto. Atualmente é Líder do Grupo de Pesquisa Cultura Brasileira, Educação e Práticas Pedagógicas(CNPQ) e Professora Associada da Universidade Estadual do Ceará. Tem experiência na área de Educação, com ênfase em Educação Artística, atuando principalmente nos seguintes temas: educação, cultura popular, estética, ensino de arte e ludicidade.

\section{ELAINE BARBOSA DE SALES}

Elaine Barbosa de Sales, graduanda em Licenciatura Plena em Música, pela Universidade Estadual do Ceará. Participa do Programa de Extensão Rede Arte na Escola, com trabalho de musicalização com professores, é professora de teclado na Escola de Música no município de Paracuru.

\section{ETHEL BATRES MORENO}

Ethel Marina Batres Moreno, guatemalteca, educadora musical, investigadora, autora de 22 libros y 32 CD's, Culminó estudios de Doctorado en Investigación Social; Magíster y Licenciada en Letras. Dirige la Licenciatura en Educación Musical en la Universidad Da Vinci y el Programa iViva la Música! Miembro Consejera del CLEA, y del Comité Asesor del FLADEM. Pertenece al Movimiento de la Canción Infantil Latinoamericana. Docente y conferencista en universidades latinoamericanas; consultora para organismos internacionales. Contacto: ethelbatres@hotmail.com
FRANCISCA ROSALIA SILVA MENEZES

Professora-pesquisadora na área de Estética, Arte Contemporânea e Performance da Unilab-CE. Realiza pesquisas e práticas artísticas na interface de artes visuais e performances cênicas. Tem graduação em Filosofia, Formação em Teatro pela Escola Pública de Teatro da Vila das Artes/ IFCE, Pós-graduação em História da Arte, Doutorado em Educação pela UFC. É Coordenadora do Grupo de Pesquisa Filosofia e Arte Contemporânea (CNPq/UNI$\mathrm{LAB})$. Atualmente está pesquisando a produção visual de mulheres artistas no pós-doutorado da Faculdade de Belas Artes da Universidade do Porto.

\section{FRANCISCO HARLEY DE OLIVEIRA}

Artista-pesquisador, atua no campo da experimentação com o audiovisual, fotografia e criação sonora a partir de instrumentos de corda e percussão. Entre a antropologia contemporânea da ciência e da tecnologia e a filosofia da diferença discute sobre temas como, aquecimento global, crises climáticas, segurança alimentar e nutricional, ecosofia, necropolítica e negacionismo. Pesquisa saberes e práticas das aldeias, das florestas, dos terreiros, do mundo rural e das feiras, para pensar territórios de encontros, nas encruzilhadas, promovendo outras relações de trocas e alianças com a natureza, em composição com a vida. Relações em que humanos e inumanos giram e se atravessam entre mandingas e encantamentos da arte, da filosofia e da ciência. Uma relação entre mundos diversos que se cruzam entre as fronteiras do pensamento, potencializando existências, permanências e resistências como ferramenta política, contra-colonialista.

\section{HELBER ROCHA RUFINO}

Helber Rocha Rufino - Graduando do Curso de Serviço Social da Universidade Estadual do Ceará. Coordenador do Grupo Cultural de Ciranda da Escola Municipal Maria Dolores Petrola de Melo Jorge, Fortaleza - CE. Professor de capoeira no Projeto Esporte Superação FETRIECE/ Governo do Estado do Ceará e no Programa Aprender Mais da referida escola. Integrante da Caravana Afro-quilombola de Caucaia. Professor Formado de Capoeira da Associação Cultural de Capoeira Liberdade.

\section{VERÔNICA CABRAL DA SILVA}

Verônica Cabral - Graduanda em Pedagogia, integra a Rede Arte na Escola, desde 2017_CE e participa do Coletivo Paulo Freire. Atua na área cultural com vivência em Maracatu e Pastoril. Participa do Grupo de Pesquisa Cultura Brasileira, Educação e Práticas Pedagógicas tendo realizado pesquisa e publicações sobre Arte e Cultura na Educação Básica. 
ILDA LIMA DE SOUSA

Ilda Lima de Sousa é estudante do Programa Doutoral em Educação Artística da Universidade do Porto/ Universidade de Lisboa; investigadora integrada, não doutorada, do i2ADS - Instituto de Investigação em Arte, Design e Sociedade da Faculdade de Belas Artes da Universidade do Porto; bolseira de doutoramento da FCT - Fundação para a Ciência e Tecnologia.

\section{INÊS CAVACO}

Inês Cavaco é co-ordenadora da Residência Artística em Govan, Escócia, no projeto internacional Memory of Water através do programa European Solidarity Corps; membro do IDENTIDADES _Movimento Intercultural; licenciada em Artes Plásticas - Pintura pela Faculdade de Belas Artes da Universidade do Porto.

\section{JEANNETTE FILOMENO POUCHAIN RAMOS} Pós-doutora em Belas Artes pela Universidade do Porto - Portugal. Doutora em Educação Brasileira pela Universidade Federal do Ceará. Professora Adjunta do Instituto de Humanidades (IH) da Universidade da Integração Internacional da Lusofonia Afro-Brasileira (UNILAB), atuando nos cursos de Pedagogia, Bacharelado em Humanidades e Mestrado Interdisciplinar em Humanidades (MIH). Líder do Grupo de Pesquisa Educação, Cultura e Subjetividade (EDUCAS/UNILAB). E-mail: ramosjeannette@unilab.edu.br

\section{JOSÉ ÁLBIO MOREIRA DE SALES}

Doutor em História pela Universidade Federal de Pernambuco (UFPE), com Estágio de Pós-Doutorado pela Universidade do Porto (U.P.), Portugal; graduado em Arquitetura e Urbanismo pela Universidade Federal do Ceará (UFC) e licenciado em Arte e Educação pela FGF. Atualmente é professor do PPGE-UECE e PPGArtes-IFCE; e do Curso de Arquitetura e Urbanismo do Unichristus. É líder do grupo de pesquisa IARTEH - Investigação em Arte Ensino e História com experiencias em temáticas das áreas de Artes, Arquitetura e Educação.

\section{JOSÉ CARLOS DE PAIVA}

Nascido no Porto em 1950. Professor Emérito da Universidade do Porto, Professor Jubilado da Faculdade de Belas Artes. Doutor em 'Pintura', Mestre em 'Arte Multimédia' e Licenciado em 'Artes Plásticas - Pintura' pela Universidade do Porto - Faculdade de Belas Artes. Investigador Integrado do i2ADS (Instituto de Investigação em Arte, Design e Sociedade), pertencendo à sua Direcção. Coordena a plataforma de investigação 'Interculturalidade e Sociedade' e o 'IDENTIDADES_Colectivo de Acção e Investigação' (ID_CAI). Percurso múltiplo por vários caminhos, aparentemente dispersos, mas relacionados por uma atitude transversal de intervenção crítica. Forte envolvimento em acções interculturais, descoloniais, de índole artístico e cultural com comunidades em Moçambique, Brasil, Cabo Verde e Portugal.

\section{LEÃO LOPES}

Leão Lopes,realizador de cinema, escritor, artista plástico, professor e investigador nascido na Ilha de Santo Antão em Cabo Verde (1948). Depois de concluídos os estudos secundários em Cabo Verde, em Lisboa gradua-se em Pintura pela Escola Superior de Belas-Artes de Lisboa. Doutor pela Universidade de Rennes II, com uma tese sobre o escritor cabo-verdiano Baltazar Lopes. Fundador da ONG Atelier Mar (Mindelo, 1979) dedicada à formação e capacitação cultural e ao desenvolvimento local, que ainda preside. Foi Ministro da Cultura e Comunicações do Governo de Cabo Verde durante a legislatura de Carlos Veiga (1991-2000) e foi deputado à Assembleia Nacional de Cabo Verde. Fundou, na Cidade do Mindelo, o Instituto Universitário de Arte, Tecnologia e Cultura (M_EIA), onde desempenha as funções de reitor e professor. 


\section{LUCIMAR BELLO FRANGE}

Lucimar Bello. Mineira, vive e trabalha em São Paulo. Artista visual: desenhos, assemblages, instalações, vídeos, performances, livros de artista. Escritora. Exposições individuais e coletivas no Brasil, Argentina, Chile, Cuba, Japão, China, Portugal, Espanha, França. Pós Doutora em Comunicação e Semiótica, PUC-SP. Pós Doutora no Núcleo de Estudos da Subjetividade, PUC-SP. Mestre e Doutora em Arte Educação ECA-USP. Profa. Titular Aposentada UFU-MG. Membro da FAEB e da ANPAP. Participante do Grupo de Pesquisa em Artes Visuais, Casa Contemporânea, São Paulo. Pesquisadora voluntária.

Livros publicados: Porque se esconde a violeta. São Paulo, Ed. Annablume. São Paulo, 1995. Noemia Varela e a arte. Belo Horizonte, C-Arte, 2002. Sete vira um (poemas), São Paulo, Livro de Artista, 2015. Caracol é uma casa que se anda (poemas). São Paulo, Ed. Labrador, 2016. Principais prêmios: Residência, Djerassi Resident Artists Program, Califórnia, 2019. Residência Artística, Fundação SACATAR, Ilha de Itaparica, 2011. 8o Salão do Mar: vasas.cidades, dos Alpes ao Ilha de Capri, menos um, menos dois, menos três. Vitória, ES. Dezembro, 2008. Bolsa de Pesquisa em Arte, FUNDAÇÃO VITAE: Cidades Utópicas, desenhos contemporâneos, São Paulo, 1994. Prêmio de Artes Plásticas - Bolsa de Desenho - $2^{\circ}$ Festival de Inverno de Ouro Preto, MG. 1987.

Curriculo Lattes - http://lattes.cnpq.br/6973661142807712 www.lucimarbello.com.br www.youtube.com/lucimarbello www.vimeo.com/lucimarbello

Facebook Lucimar Bello Frange

@lucimarbellofrange

lucimarbello@terra.com.br

\section{MADALENA ZACCARA}

Madalena Zaccara é bacharel em arquitetura e urbanismo pela Universidade Federal de Pernambuco;tem doutorado em História da Arte pela Université Toulouse II < Toulouse, França; Pós-doutorado pela Faculdade de Belas Artes da Universidade de Porto sob a tutoria do Prof. Dr. José Carlos de Paiva(2016) e pela Sorbonne, Paris tendo como tutor o Prof. Dr. Michel Maffesoli (2019). É professora titular da Universidade Federal de Pernambuco, faz parte do Programa de Pós-Graduação em Artes Visuais UFPE-UFPB; é co editora da Revista Cartema daquele programa e vice-presidente da Associação $\mathrm{Na}$ cional dos Pesquisadores de Artes Plásticas (ANPAP). Madalena tem vários livros, capítulos de livros e artigos publicados. Contato: madazaccara@gmail.com
MARIA ARIDENISE MACENA FONTENELLE Graduação em Engenharia Civil pela Universidade de Fortaleza (1991), mestrado(1994) e doutorado (2004) em Engenharia de Produção pela Universidade Federal de Santa Catarina. Atualmente é professora Associada da Universidade Federal Rural do Semiárido (UFERSA) e Integra o corpo docente do Programa de Pós-Graduação em Cognição, Tecnologias e Instituições (PPGCTI)) da UFERSA. Tem experiência na área de Engenharia Civil, com ênfase em Materiais e Componentes de Construção, atuando principalmente nos seguintes temas: construção civil, canteiro de obras, qualidade, aprendizagem em engenharia. Formação em Pedagogia Waldorf, Vice- Coordenadora do Programa Oficinando em Rede da UFERSA onde estuda o tema saúde mental e artes.

\section{MARIA KELLYNIA FARIAS ALVES}

Possui doutorado em Educação pela Universidade Federal do Ceará (2020). Atualmente é professora substituta da Universidade Estadual do Ceará, professora na Educação Básica da Prefeitura Municipal de Caucaia. Atuando principalmente nos seguintes temas: Formação continuada, Relações étnico-raciais, EJA, juventudes, educação indígena, educação e cultura popular e Pretagogia. Encantada pelas estéticas ancestrais e de resistência. Membra do Núcleo das Africanidades Cearenses-NACE/UFC e do Núcleo de Educação Popular - CED/UECE.

\section{NÚBIA AGUSTINHA CARVALHO SANTOS}

Núbia Agustinha - Formação em Artes Visuais pelo Instituto Federal de Educação, Ciência e Tecnologia do Ceará (IFCE) e pela Escola Porto Iracema das Artes (Fortaleza-CE); formação em Pedagogia pela Universidade Federal do Ceará (UFC). Doutorado em Educação Brasileira pela mesma instituição. Atua como pesquisadora, arte educadora e artista visual. Sua produção poética é atravessada pela escrita, gravura, instalação e performance. No momento, é professora temporária da Universidade Estadual do Ceará (UECE); e membro do Grupo Meio Fio de Pesquisa e Ação (IFCE). 
PATRÍCIA MARTINS

Possui graduação em Educação Artística pela UNOESTE (2008). Especialização em Metodologia do ensino da Arte pelo Grupo UNINTER, FACINTER e FATEC (2010), Especialização em História da Arte pela FACCREI (2013), Especialização em Arte Educação pela UNESP (2016). Professora de Arte da Rede Estadual e Particular de Ensino, tem experiência na área de Arte, com ênfase em Educação Artística, Desenho, Artes Plásticas e História da Arte. Em 2020 obteve o título de Mestre como bolsista no Programa PROFARTES de Mestrado Profissional da CAPES, no Instituto de Artes da Unesp com o trabalho "O DESENHO NA ESCOLA: Esboçando uma compreensão a partir de alguns professores de Arte de Pirapozinho/SP". Disponível em <https://repositorio. unesp.br/handle/11449/193200>.

\section{RITA RAINHO}

Artista e Investigadora. Atualmente desenvolve o seu projecto de investigação "Descolonização da Educação Artística: A Possibilidade de Outras Práticas de Educação Artística na CPLP" (CEEC - FCT) enquanto membro integrado do i2ADS/FBAUP. Doutorada em Educação Artística (Bolsa FCT), 2018 (FBAUP, Porto [PT] - Portugal); Professora no Instituto Universitário de Tecnologia e Cultura da Arte, [CV] (2012 - 2016); no Instituto Universitário de Educação, 2015-2016 [CV]; no Instituto Superior de Arte e Cultura, 2010 [MZ], na Escola Nacional de Artes Visuais, 2009, 2010 [MZ]. Trabalhou no design e ilustração nos Manuais Escolares de Educação Artística $[\mathrm{CV}]$ e é colaboradora no CNAD - Centro Nacional de Arte, Artesanato e Design [CV].É membro dos projetos coletivos 'movimento intercultural Identidades' desde 2005 [PT, CV, MZ e BR], desde 2015 Oficina de Utopias $[\mathrm{PT}, \mathrm{CV}], \mathrm{PIF}$ - Projetar a Independência no Feminino [CV] e desde 2018 Neve Insular [CV].
TÂNIA MARIA DE SOUZA FRANÇA Doutora e Mestra em Educação pelo PPGE da Universidade Estadual do Ceará-UECE; Graduada em Serviço Social (UECE) e Licenciada em Pedagogia, pela Universidade Metodista. Atualmente é professora assistente da Universidade Estadual do Ceará - lotada na Faculdade de Educação, Ciências e Letras de Iguatu - FECLI. É membro do grupo de pesquisa IARTEH - Investigação em Arte Ensino e História com experiências em temáticas das áreas de Artes e Educação.

\section{TIAGO MORAIS FREITAS}

Bacharel em Humanidades pela Universidade da Integração Internacional da Lusofonia Afro-Brasileira (UNILAB) e discente do curso de Licenciatura plena em Pedagogia pela mesma Universidade. Integrante do Grupos de Pesquisa Educação, Cultura e Subjetividades (EDUCAS/ UNILAB) e Práticas sociais e Processos Educativos da Universidade Federal de São Carlos (UFSCar). E-mail: tiagomorais@aluno.unilab.edu.br 


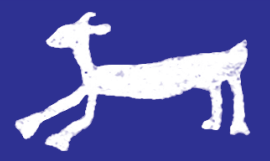

